ANA CAROLINA DEVITO DEARO

\title{
O INADIMPLEMENTO RECÍPROCO NO CONTRATO DE DISTRIBUIÇÃO: CARACTERIZAÇÃO E CONSEQUÊNCIAS
}

\author{
Dissertação de mestrado em Direito Comercial \\ Orientador: Professor Doutor José Alexandre Tavares Guerreiro
}

Faculdade de Direito

Universidade de São Paulo

São Paulo 
ANA CAROLINA DEVITO DEARO

\section{O INADIMPLEMENTO RECÍPROCO NO CONTRATO DE DISTRIBUIÇÃO: CARACTERIZAÇÃO E CONSEQUÊNCIAS}

Dissertação apresentada à Faculdade de Direito da Universidade de São Paulo como requisito parcial à obtenção do grau de Mestre na área de concentração de Direito Comercial.

Orientador: Prof. Dr. José Alexandre Tavares Guerreiro.

Faculdade de Direito

Universidade de São Paulo

São Paulo

2014 
Banca Examinadora 


\section{ÍNDICE}

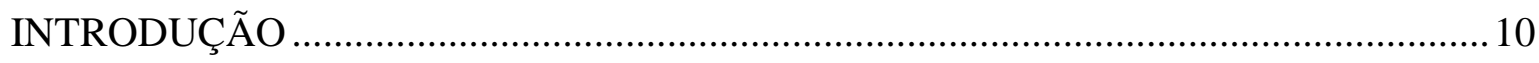

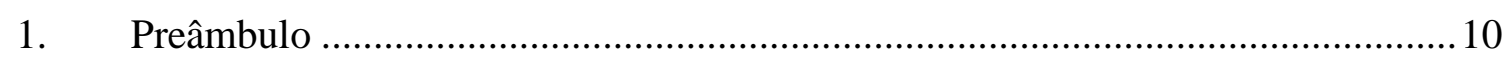

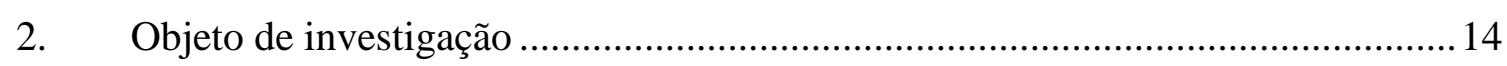

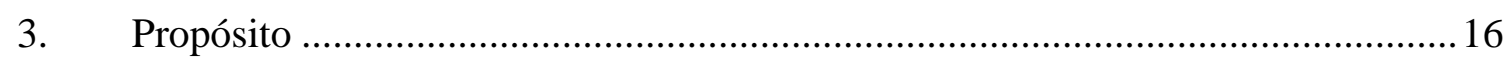

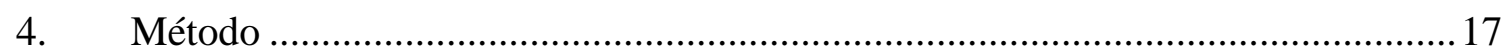

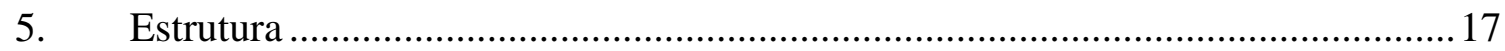

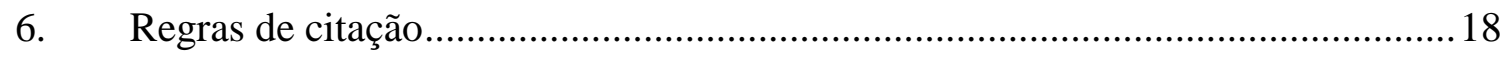

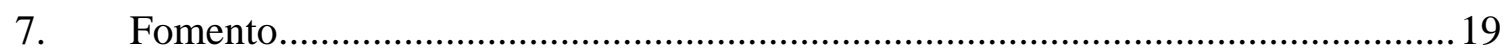

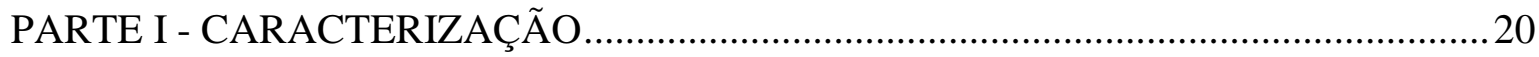

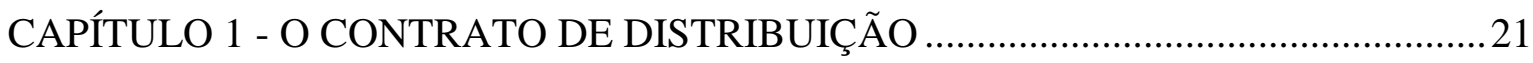

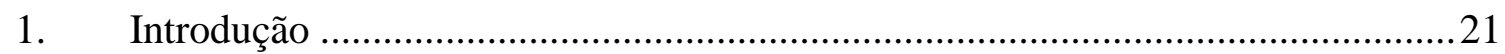

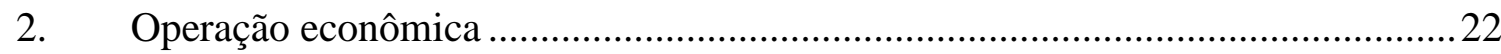

3. Caracterização do contrato de distribuição ...........................................................2

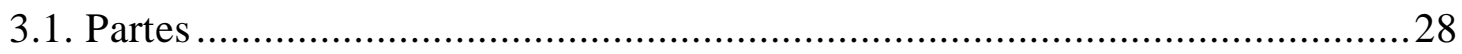

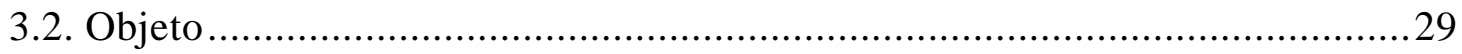

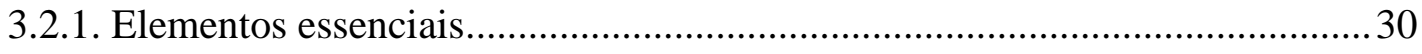

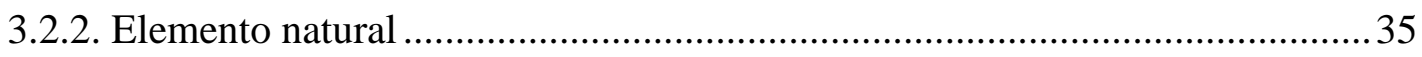

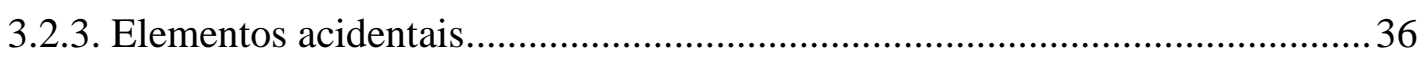

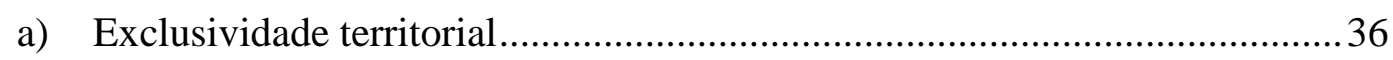

b) Exclusividade de comercialização .......................................................... 37

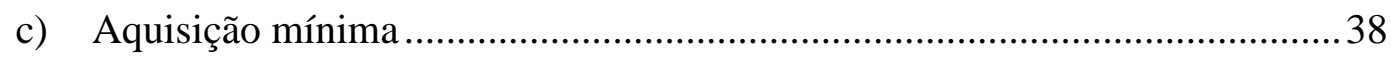

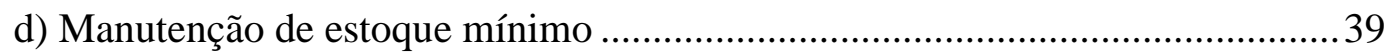

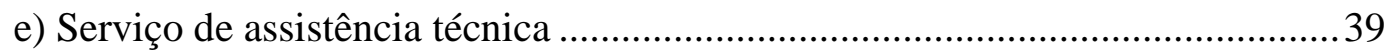

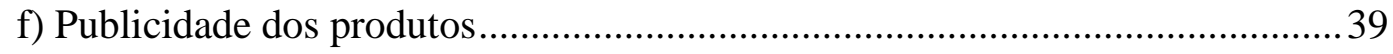

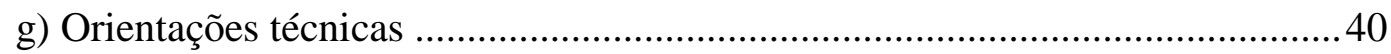

h) Prestação de informações sobre o mercado .................................................. 40 
3.2.4. Usos e boa-fé 40

3.3. Forma 42

4. As diferenças em relação aos contratos afins....................................................... 43

4.1. Contrato de agência (representação comercial) ..........................................44

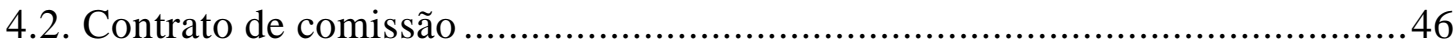

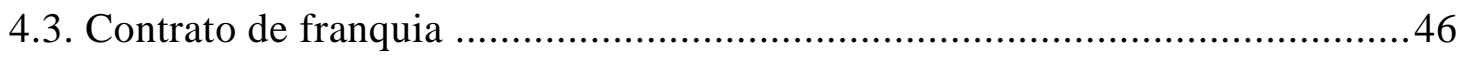

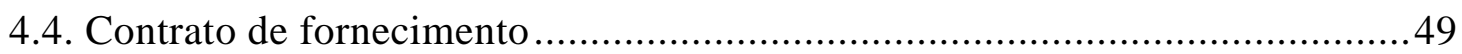

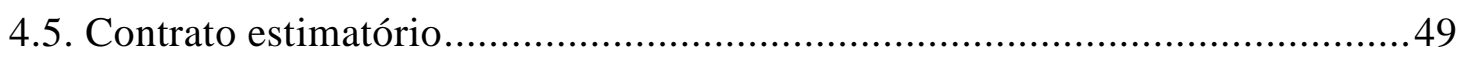

5. Classificação do contrato de distribuição........................................................... 50

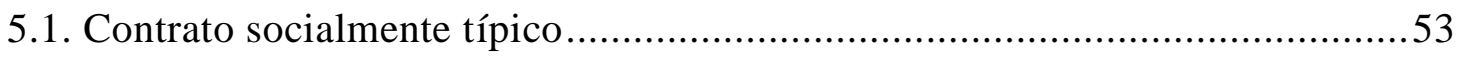

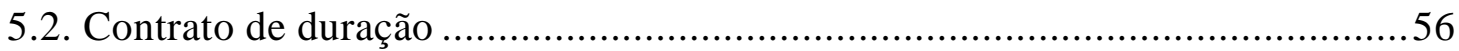

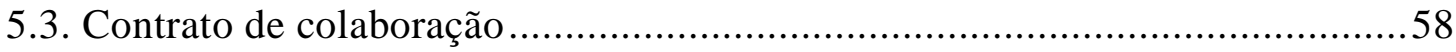

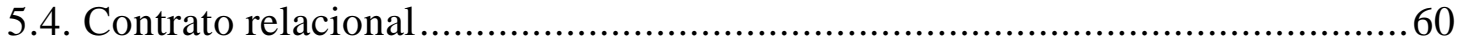

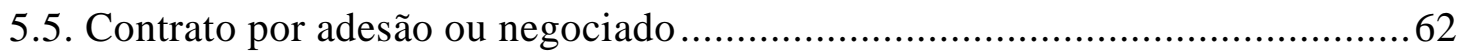

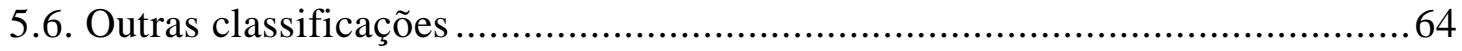

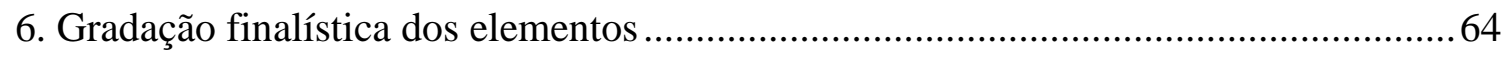

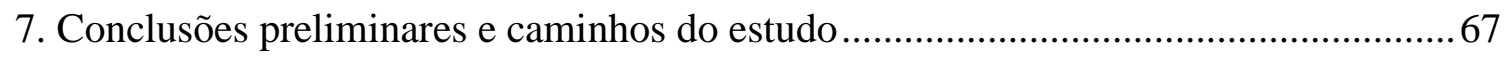

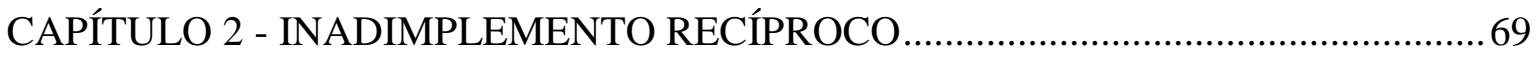

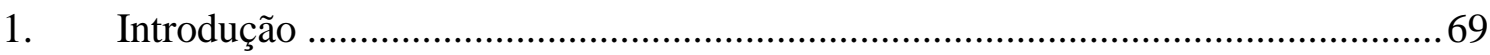

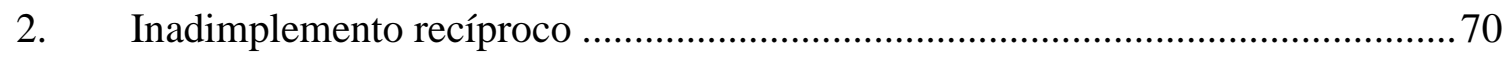

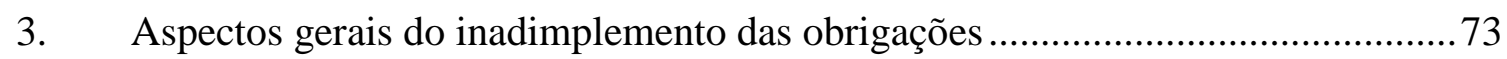

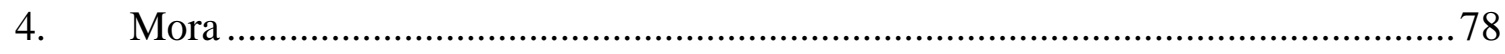

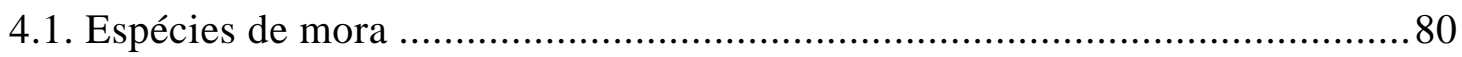

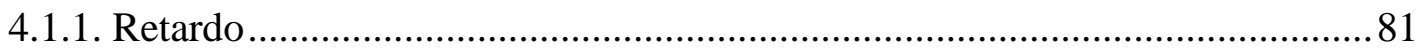

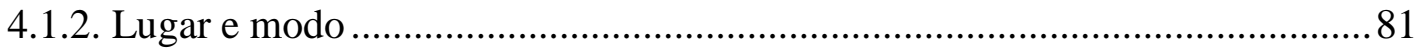

4.1.3. A mora frente à relação obrigacional complexa ........................................... 82

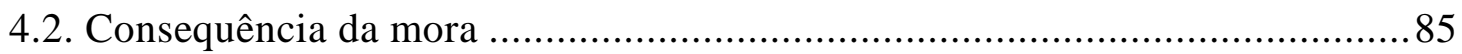




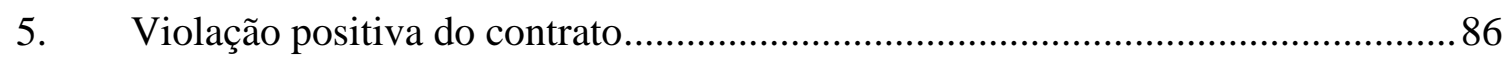

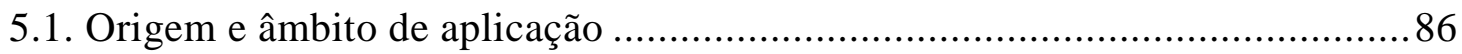

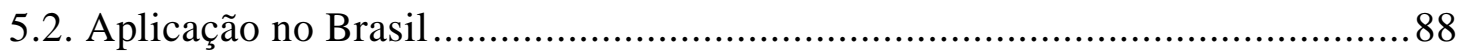

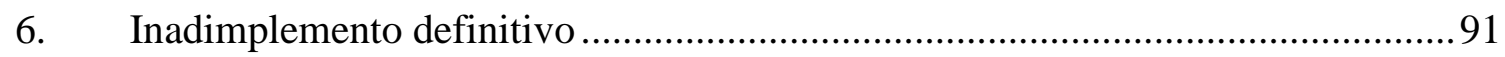

6.1. Transformação da mora em inadimplemento definitivo ..............................92

6.2. Critérios para aferir a utilidade da prestação ............................................ 94

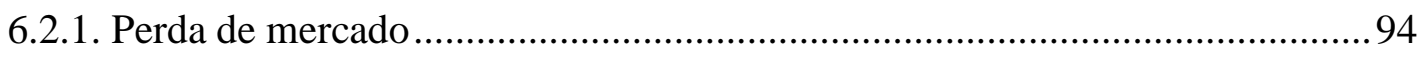

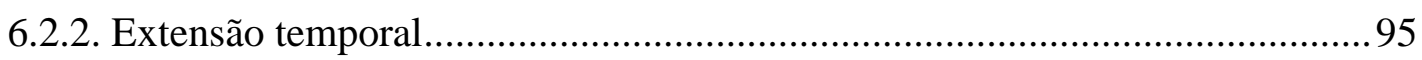

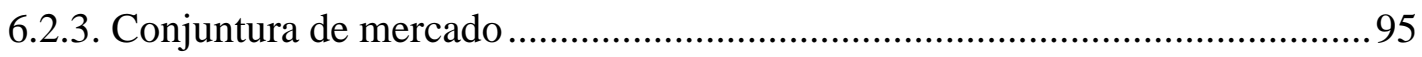

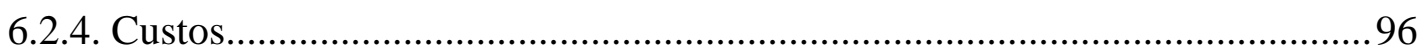

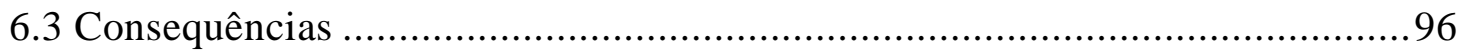

7. Conclusões preliminares e caminhos do estudo ............................................... 97

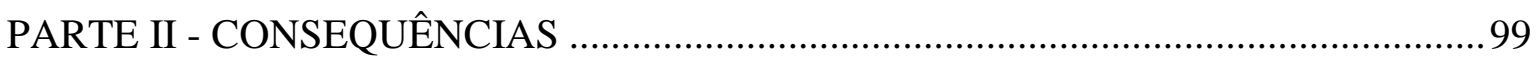

CAPÍTULO 1 - AS REPERCUSSÕES DO INADIMPLEMENTO ................................ 100

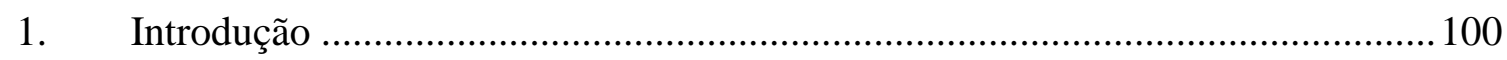

2. Realização coativa da prestação .................................................................... 101

2.1. Modalidades de obrigações ........................................................... 103

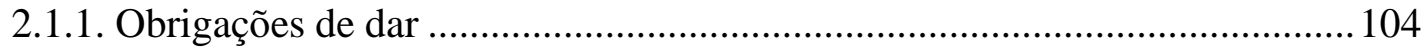

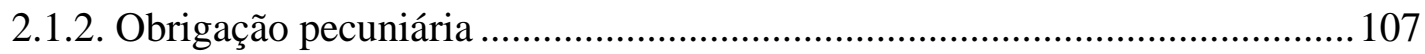

2.1.3. Obrigações de fazer ........................................................................... 108

2.1.4. Obrigações negativas .......................................................................... 109

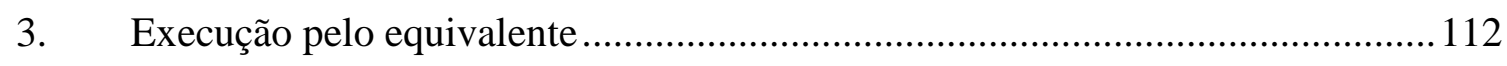

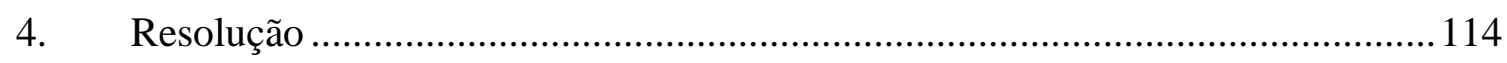

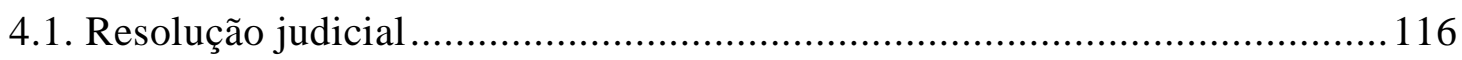

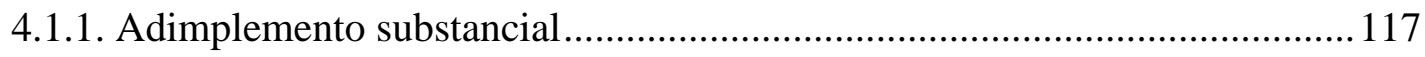

4.1.2. Inadimplemento de escassa importância..................................................... 118

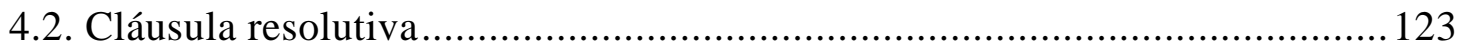

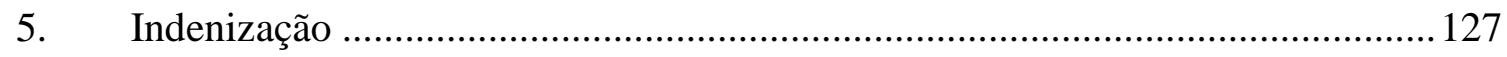


5.1. Indenização do interesse positivo 129

5.2. Indenização do interesse negativo 130

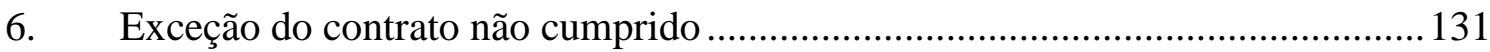

7. Conclusões preliminares e caminhos do estudo ................................................ 132

CAPÍTULO 2 - AS REPERCUSSÕES DO INADIMPLEMENTO RECÍPROCO ......... 136

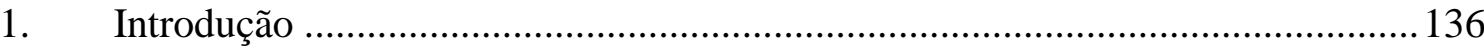

2. Breve síntese da doutrina e jurisprudência........................................................ 138

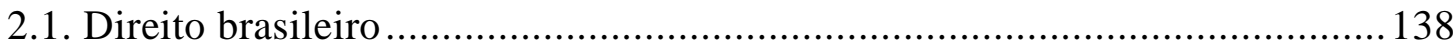

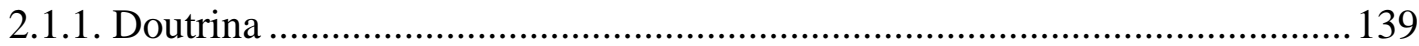

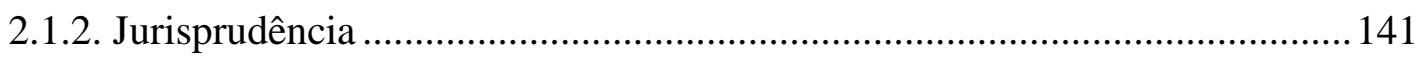

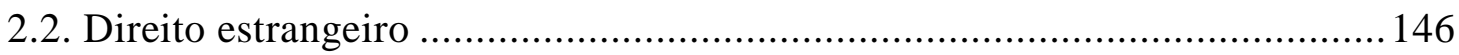

3. Casos de preservação da relação contratual ...................................................... 149

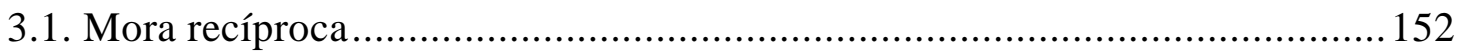

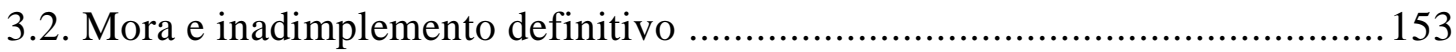

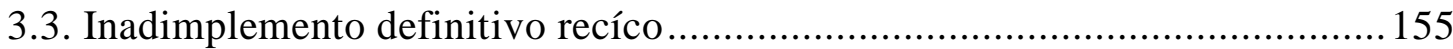

3.4. Mora e adimplemento substancial ou inadimplemento desimportante .......... 156

3.5. Inadimplemento definitivo e adimplemento substancial ou inadimplemento

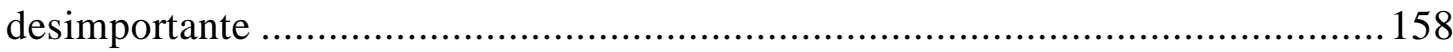

3.6. Adimplemento substancial recíproco ou inadimplemento desimportante

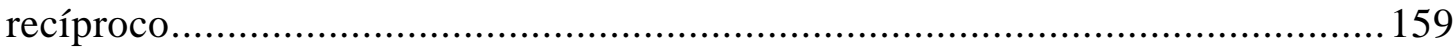

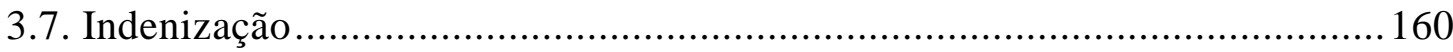

4. Casos de extinção da relação contratual............................................................. 162

4.1. Pedido de resolução formulado por um contratante ................................... 163

4.1.1. Mora e execução específica .................................................................... 163

4.1.2. Inadimplemento definitivo e execução pelo equivalente............................. 164

4.2. Pedidos de resolução formulados por ambos os contratantes ...................... 166

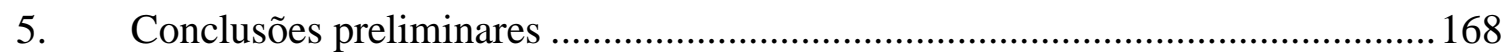

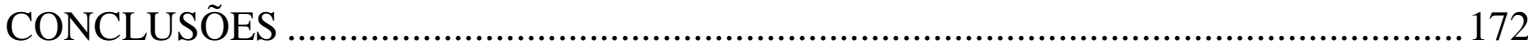




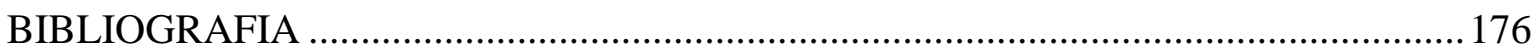

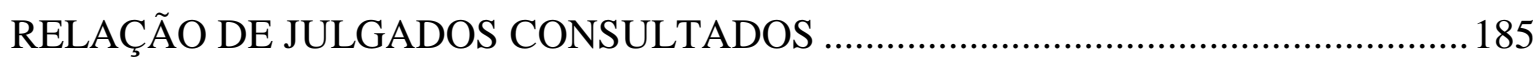

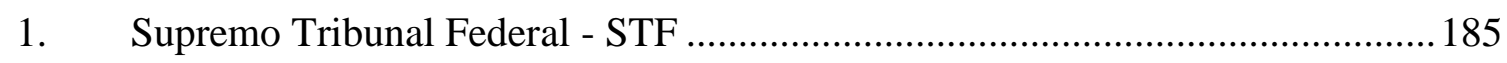

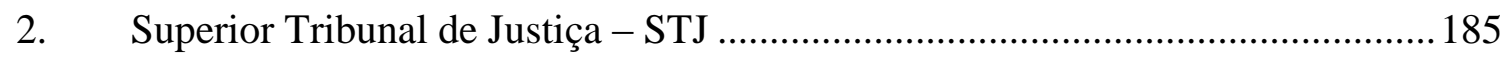

3. Tribunal de Justiça do Estado de São Paulo - TJSP ...............................................185

4. Tribunal de Alçada Civil do Estado de São Paulo - $1^{\circ}$ TACivSP ..........................187

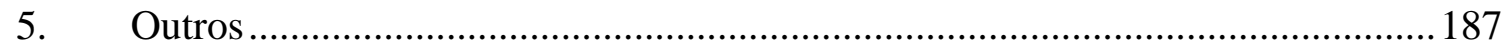

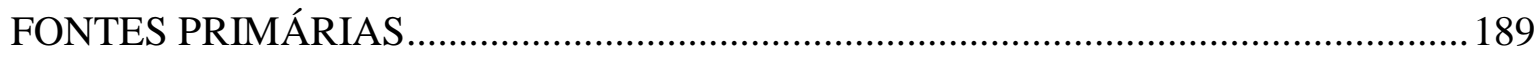

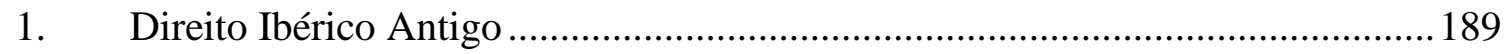

Código Filipino ou Ordenações e Leis do Reino de Portugal ........................... 189

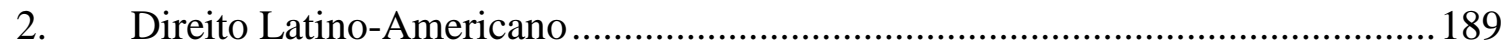

Argentina

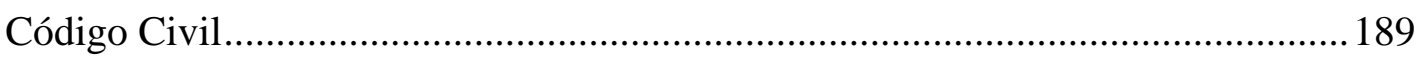

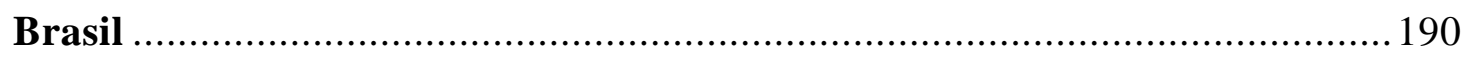

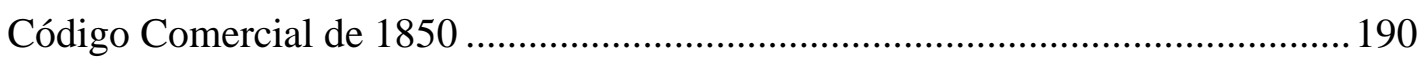

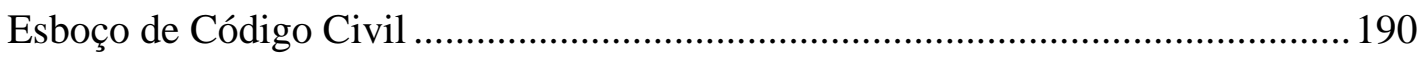

Projeto de Código Civil de 1881 .......................................................................... 190

Projeto de Código Civil de 1893..............................................................................191

Projeto Primitivo do Código Civil de Clovis Bevilaqua............................................191

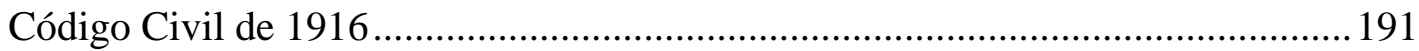

Anteprojeto da Parte Geral do Código de Obrigações de 1941 ................................191

Anteprojeto de Código de Obrigações de 1963 ........................................................ 192

Projeto de Código de Obrigações de 1965 ...............................................................192

Projeto de Código de Civil de 1975 .......................................................................... 192

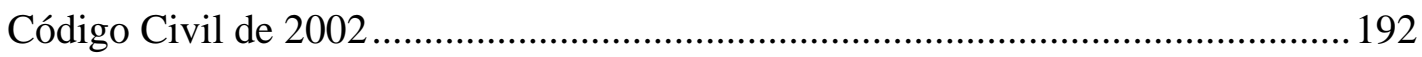

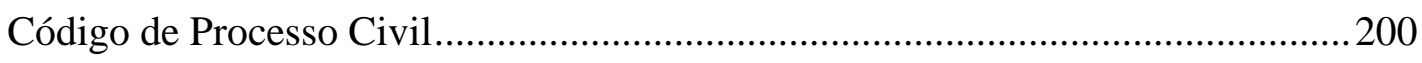

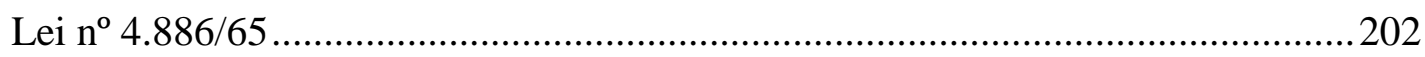

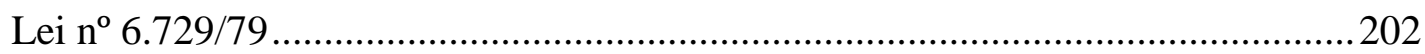




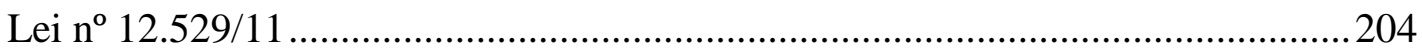

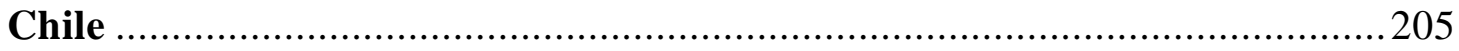

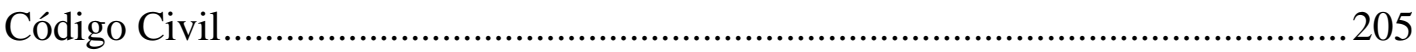

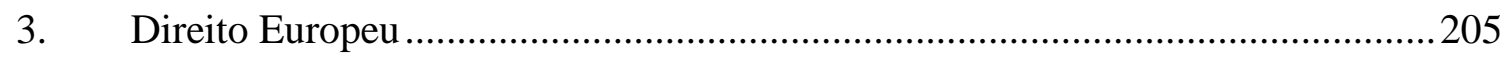

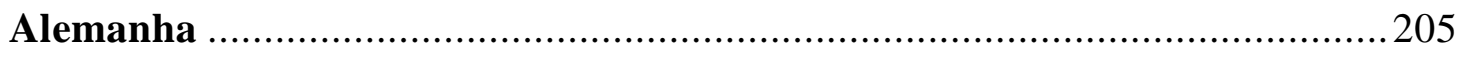

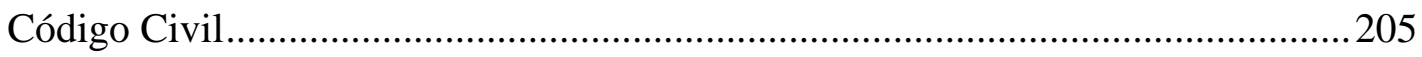

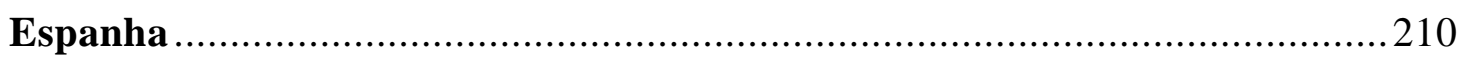

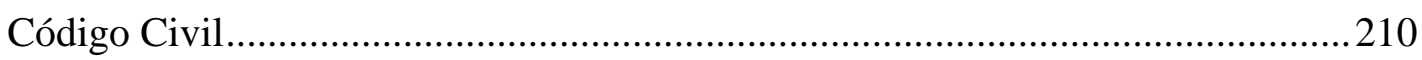

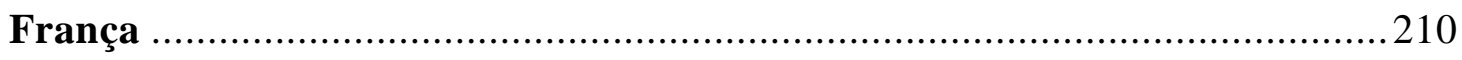

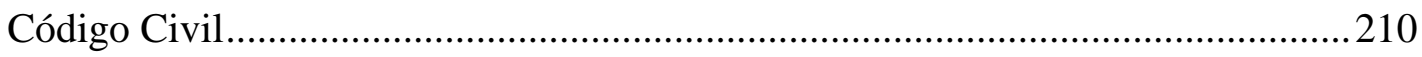

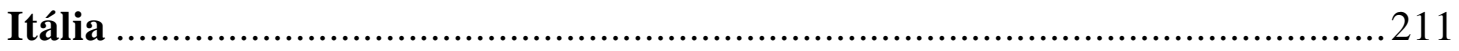

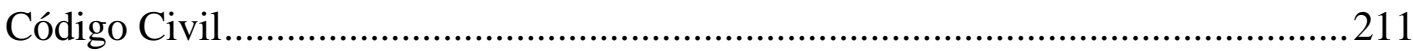

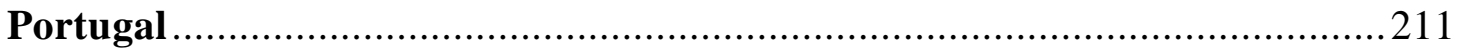

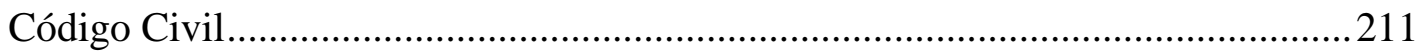

4. Projetos de unificação do direito dos contratos.................................................212

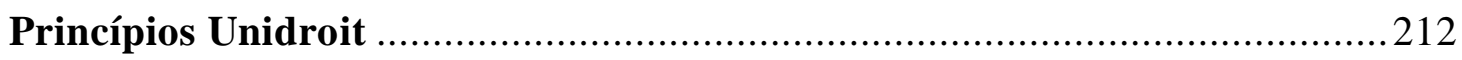

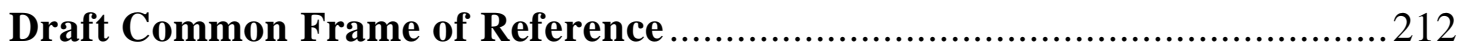

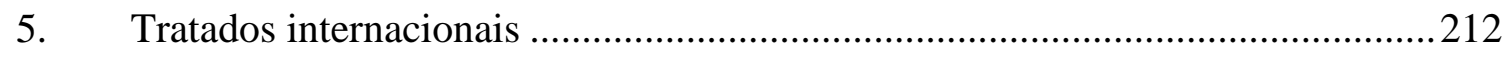

Convenção de Viena de 1980 sobre os contratos de compra e venda internacional de mercadoria................................................................ 213

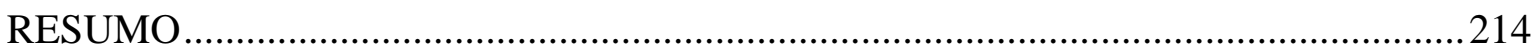

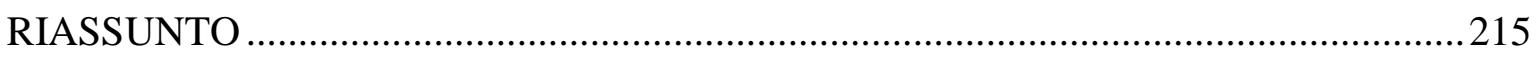




\section{INTRODUÇÃO}

\section{Preâmbulo}

O contrato é a veste jurídica da operação econômica e serve, essencialmente, à criação e circulação de riquezas. Os tipos negociais prestam-se, assim, a oferecer um modelo jurídico para disciplinar dada operação econômica.

O contrato de compra e venda, por exemplo, trata da operação econômica por meio da qual se troca dado bem por certo valor em dinheiro.

Os contratos de distribuição, por sua vez, conectam a fase de produção ao destinatário final da mercadoria. Representam, deste modo, uma das mais importantes ferramentas disponíveis ao empresário para viabilizar o escoamento de sua produção pelo sistema de vendas indiretas.

Neste contrato tipicamente empresarial ${ }^{1}$, o fornecedor obriga-se a entrega reiterada de certos bens ao distribuidor para que este os revenda, tendo como proveito econômico a diferença entre preço de aquisição e de revenda.

Não obstante ao crescente emprego deste negócio, o estudioso interessado em compreender a figura encontra inúmeras dificuldades, o que decorre, em parte, do desenvolvimento ainda incipiente de uma teoria geral dos contratos empresariais.

A dogmática comercialista, em sua maioria, dedica-se aos contratos em espécie e relega a sistematização de normas gerais ao direito civil ${ }^{2}$. Esta conjuntura não é de se estranhar quando se leva em consideração o percurso histórico por qual passaram as obrigações de direito comercial no país ${ }^{3}$.

O Brasil tornou-se independente de Portugal em 07 de setembro de 1822. Continuaram, no entanto, em vigor no Império do Brasil, de acordo com a Lei de 20 de outubro de 1823, as Ordenações Filipinas, Leis, Decretos e Resoluções de Portugal promulgadas até 15 de abril de 1821 .

\footnotetext{
${ }^{1}$ No presente trabalho, as expressões contratos comerciais, mercantis e empresariais são empregadas como sinônimas. O mesmo ocorre com as expressões Direito comercial, mercantil e empresarial.

${ }^{2}$ Cf. Forgioni, Paula A. Teoria geral dos contratos empresariais. São Paulo: Editora Revista dos Tribunais, 2009. p. 17.

${ }^{3}$ Os dados históricos abaixo mencionados foram extraídos da seguinte obra: MOREIRA ALVES, José Carlos. A unificação do direito privado brasileiro - de Teixeira de Freitas ao Novo Código Civil. In: CARBONE, Paolo; JunqueIra de Azevedo, Antonio; Tôrres, Heleno Taveira. Princípios do Novo Código Civil brasileiro e outros temas: homenagem a Tullio Ascarelli. 2a ed. São Paulo: Quartier Latin, 2010. p. 369-391.
} 
Em virtude da pressão dos comerciantes, que pleiteavam um Tribunal para julgar suas causas, iniciou-se a elaboração de um Código Comercial já em 1831. No ano de 1850, este foi promulgado e logo seguido pelo Regulamento 737, incumbido de disciplinar as causas relativas aos comerciantes. Sua edição evidenciava a dicotomia entre processo civil e comercial que tinha, então, lugar entre nós.

Em 1855, o Governo Imperial contratou Teixeira de Freitas para compilar toda a legislação civil vigente, o que veio a ser a Consolidação das Leis Civis. Dada à qualidade do texto, decidiu-se encarregar o mesmo jurista para elaborar o Projeto de Código Civil.

Foi, então, redigido o Esboço de Código Civil, no qual se sugeriu a unificação da disciplina das obrigações civis e comerciais. O Esboço, todavia, não chegou a ser concluído e tampouco foi convertido em lei. Teixeira de Freitas também propôs a elaboração de um Código Geral, que compreenderia as regras sobre publicação, interpretação e aplicação de leis em todos os ramos do Direito. Sua sugestão, todavia, não encontrou eco à época junto governo imperial.

O Código Civil veio somente em 1916 baseado no Projeto de Clóvis Bevilaqua. O estatuto conservou a distinção entre obrigações de direito civil e de direito comercial, pois, ao seu lado, persistia o Código Comercial de 1850.

Cabe, porém, anotar que quando da aprovação do Código, a unificação contava com o apoio de inúmeros doutrinadores, como Brasílio Machado, Dídimo da Veiga, Carlos de Carvalho, Inglês de Souza e Carvalho de Mendonça ${ }^{4}$. Ademais, com o fim da justiça especial para os comerciantes, iniciado com o Decreto 763 de 1890 e consolidado com o Código de Processo Civil de 1939, a distinção entre contratos civis e mercantis perdeu, na prática, muita de sua importância ${ }^{5}$.

As diferenças entre estes contratos foram, gradativamente, superadas pela doutrina e jurisprudência, por meio, especialmente, do art. 121 do Código Comercial, cujo texto determinava a aplicação subsidiária do direito civil aos contratos em geral.

A aproximação entre estes ramos culminou com o Código Civil de 2002, o qual estabeleceu a unificação das obrigações civis e comerciais. O Código Comercial de 1850, por sua vez, permanece em vigor tão somente em relação ao direito marítimo.

Ocorre, entretanto, que a unificação, defendida ao longo de décadas, acarretou certo descaso pela teoria geral dos contratos empresariais ${ }^{6}$. Tal cenário resta evidente, por

\footnotetext{
${ }^{4}$ Cf. Moreira Alves, José Carlos. A unificação do direito privado brasileiro, op. cit., p. 379.

${ }^{5}$ Cf. Bulgarelli, Waldirio. Contratos mercantis. $14^{a}$ ed. São Paulo: Atlas, 2001. p. 43.

${ }^{6}$ Neste sentido cf. ForgIONI, Paula A Teoria geral dos contratos empresariais, op. cit., p. 40.
} 
exemplo, diante das dificuldades interpretativas com que se depara o estudioso interessado em compreender o contrato de distribuição, em detrimento da importância e do uso cada vez mais frequente deste tipo negocial, conforme também alerta a jurisprudência ${ }^{7}$.

O atento exame do contrato de distribuição revela, porém, que as dificuldades não se relacionam unicamente com a natureza comercial do referido negócio. Muitas das questões que se apresentam no decorrer da vida deste tipo negocial estão intrinsecamente ligadas ao seu enquadramento como um contrato de duração e de colaboração.

O tempo afeta sobremaneira a economia dos contratos. Em primeiro lugar, subordina as prestações ao risco de transformações ${ }^{8}$. Uma prestação perfeitamente possível, no momento da formação do contrato, pode não mais o ser quando de sua execução. Basta pensar em incêndio que atinge o depósito do vendedor e destrói as mercadorias que seriam entregues ao comprador na semana seguinte.

Em adição, todo contrato de duração submete-se ao risco de inadimplemento de modo mais acentuado que um contrato de prestação instantânea ${ }^{9}$. No curso da existência do contrato, o contratante pode, por exemplo, vir a sofrer falência ou a arrepender-se e, consequentemente, descumprir o pactuado. As alterações podem ainda não se relacionar com o contratante, tal qual ocorre com a descoberta de um risco geológico em contrato de empreitada. Neste contrato, enquanto a obra não está pronta, permanecem os riscos desta não se consumar, de não se consumar a tempo ou ainda de sofrer modificações que a onerem além do previsto pelos contratantes.

Se os contratos de duração apresentam peculiaridades já no momento de sua formação e execução, a extinção de negócios destinados a protrair-se no tempo tende a gerar ainda mais conflitos, sobretudo, quando fundada na inexecução do contrato. A complexidade para se aferir o momento em que uma prestação torna-se realmente inútil em um contrato de duração e, por conseguinte, identificar se há apenas um atraso no cumprimento ou se este se tornou para sempre irrealizável, transformando a simples mora em um inadimplemento definitivo, é exemplo que bem ilustra as dificuldades que emergem nesta modalidade de negócio.

A evolução social e jurídica fez com que os contratos de duração alcançassem posição cada vez mais destacada. As obrigações de dar, presentes nos contratos de

\footnotetext{
7 “Quando misto o empreendimento surgem inexoráveis e tormentosas controvérsias. Assim, por exemplo, na revenda de automóveis, eletrodomésticos, combustível e outros bens". (TJSP, Ap. Civ. no 991.09.023753-7, $13^{\text {a }}$ Câm. Dir. Priv., r. Des. Luiz Sabbato, j. 07.04.2010).

${ }^{8}$ Sobre a influência do tempo nos contratos cf. VILLELA, João Baptista. Equilíbrio do contrato: os números e a vontade. Revista dos Tribunais, São Paulo, vol. 900, p. 85-121, out. 2010.

${ }^{9}$ Cf. VIllele, João Baptista. Equilíbrio do contrato, op. cit., p. 94.
} 
intercâmbio, como a compra e venda e a permuta, passaram a conviver com obrigações de fazer em negócios destinados a protrair-se no tempo. $\mathrm{O}$ direito, frente à evolução do mercado, teve que produzir novas regras para uma série de contratos de longa duração como, por exemplo, o contrato de locação, o contrato de fornecimento, o contrato de seguro, o contrato de trabalho, entre tantos outros.

O contrato de distribuição, no entanto, vai além da categoria dos contratos de duração. Tal negócio, não apenas é destinado a durar cinco, dez anos, tal qual o contrato de fornecimento, como ainda se enquadra na categoria dos contratos de colaboração.

Os contratos de colaboração se caracterizam pela obrigação assumida por um dos contratantes de perseguir os interesses de sua contraparte. Trata-se, mais precisamente, de uma atividade que é desenvolvida pela parte e composta por um ou mais atos que não incidem sobre sua esfera jurídica, mas sobre a de sua contraparte ${ }^{10}$.

O termo atividade designa uma série de atos coordenados entre si em função de uma finalidade comum ${ }^{11}$. A ideia de atividade encontra-se bastante familiarizada com o Direito Societário. Nos termos do art. 966 do Código Civil, a ocorrência de determinada atividade confere a certa pessoa o status de empresário, com a consequente aplicação de regime próprio.

Convém notar, entretanto, que o regramento da atividade não tem lugar exclusivamente no âmbito do Direito Societário. No contrato de distribuição, a presença de uma atividade colaborativa entre as partes resta clara. Por meio deste tipo negocial, o fornecedor faz chegar ao mercado seus próprios produtos vendendo-os ao distribuidor, o qual se obriga a revendê-los ao destinatário final em dada área de atuação.

$\mathrm{O}$ enquadramento do contrato de distribuição na categoria dos contratos de colaboração faz emergir, em última análise, dificuldades relacionadas à distinção do regime jurídico da atividade e dos vários atos singularmente considerados. Para a exata compreensão disto, vale pensar que a atividade voltada à formação do cartel entre vários distribuidores e, portanto ilícita, não implica necessariamente a nulidade das compras de insumos realizadas por seus participantes.

Os atos são os veículos geradores de direitos e obrigações por excelência, ao passo que a atividade reflete a importância assumida pelo comportamento reiterado em face do tratamento personalizado. Ao se comparar ambos, pode-se perceber que o estudo do

\footnotetext{
${ }^{10}$ Neste sentido, cf. SIRENA, Pietro. La categoria dei contratti di colaborazione. In SIRENA, Pietro (a cura di). I contratti di collaborazione. Torino: UTET, 2011. p. 3-23.

${ }^{11}$ Cf. AsCARelli, Tullio. Corso di Diritto Commerciale: Introduzione e Teoria dell'impresa. $3^{a}$ ed. Milano: Giuffrè, 1962. p. 147.
} 
contrato de distribuição não deve ficar restrito unicamente ao momento estático do Direito, sendo necessário aprofundar-se também na dinâmica da vida jurídica, já que estes institutos se complementam e se integram.

A classificação do contrato de distribuição como um negócio jurídico de duração e de colaboração chama a atenção, todavia, para a conveniência do regramento presente no Código Civil diante dos problemas que surgem no âmbito deste contrato.

As prescrições constantes do Código Civil cuidam de uma generalidade de casos e, para tanto, tomam como referência, na maioria das oportunidades, os contratos de intercâmbio e de execução instantânea. As regras foram desenhadas tendo em vista, notadamente, o contrato de compra e venda, um dos tipos negociais mais antigos e desenvolvidos na prática mercantil.

Não é difícil, por exemplo, identificar os pressupostos necessários ao manejo da exceção do contrato não cumprido em uma compra e venda, sobretudo se as partes se obrigam a executar simultaneamente as respectivas prestações.

Pode-se dizer que os dispositivos legais adéquam-se com maior facilidade aos contratos de intercâmbio de execução instantânea. Tal harmonização, no entanto, decresce de maneira gradual frente aos contratos de duração e de colaboração.

Tais categorias de negócios colocam em xeque, portanto, a adequação das normas presentes no Código Civil frente a arranjos mais complexos e, por conseguinte, sua aplicação nestes negócios enseja reflexão. Somente o manejo correto de tais ferramentas contribuirá ao bom funcionamento do mercado e permitirá que os contratos empresariais promovam a circulação e criação de riqueza que justifica sua tutela jurídica.

São em situações como esta que o trabalho do pesquisador do Direito afigura-se essencial. O Direito precisa oferecer uma resposta coerente ao problema, afinal sua essência é a realização prática ${ }^{12}$.

\section{Objeto de investigação}

O estudo trata da caracterização e das consequências do inadimplemento recíproco nos contratos de distribuição. A pesquisa recai em situações como a enfrentada por um distribuidor de bebidas que, contrariando o estabelecido no contrato, passa a vender produtos de outra marca, ao passo que o fornecedor quebra a exclusividade territorial e

\footnotetext{
${ }^{12}$ IHERING, Rudolf Von [trad. João Vasconcellos]. A luta pelo direito. 16 ed. Rio de Janeiro: Forense, 1996. p. 43.
} 
abre, para venda direta, um estabelecimento na mesma localidade. Ou, ainda, um distribuidor de produtos luxuosos que os vende a preços que, de tão baixos, aviltam o bom nome da marca, enquanto o fornecedor exige a compra excessiva de peças para estoque.

Trata-se de tema que se situa nos limites entre o direito civil e o direito empresarial. Isso, de um lado, o torna pouco estudado como a maioria dos temas limítrofes e, de outro, cria a necessidade de se debruçar, acuradamente, sobre dois pilares: o direito obrigacional e o contrato de distribuição, marcado pelas especificidades das categorias de contrato de duração e de colaboração.

No âmbito do direito obrigacional, convém, desde logo, ter presente que o Código Civil disciplina tão somente o inadimplemento singular, relacionado à inexecução por uma das partes das obrigações contraídas. Nada dispõe, porém, a respeito do descumprimento por ambos os contratantes, razão pela qual se mostra oportuna à intervenção da doutrina no particular.

A questão assume especial relevância no âmbito do contrato de distribuição, posto que o sucesso de tal negócio reclama não apenas o cumprimento da própria parte, mas também, com particular intensidade, a execução das obrigações de seu contratante. A duração do negócio também produz relevantes consequências, especialmente, sobre a definição da mora e do inadimplemento definitivo.

A investigação almeja, deste modo, estudar o inadimplemento recíproco ocorrido no âmbito de um contrato de distribuição. Em última medida, o trabalho se presta a complementar o regramento legal que, embora tenha disciplinado o inadimplemento, nada esclareceu sobre o descumprimento recíproco e tampouco sobre sua ocorrência nos contratos de distribuição, havendo um descompasso entre a realidade negocial e sua disciplina jurídica.

Cumpre anotar que são, porém, excluídos da presente investigação os contratos regulados pela Lei ${ }^{\circ}$ 6.729/79. Esta Lei, também conhecida como Lei Ferrari, dispõe sobre a concessão comercial entre produtores e distribuidores de veículos automotores de via terrestre e traz um sistema próprio para a resolução com a previsão de penas gradativas.

Para bem precisar o objeto de estudo, vale anotar ainda que o contrato de distribuição interessa de modo particular ao direito concorrencial, porquanto, na perspectiva deste ramo do Direito, figura entre os chamados acordos verticais. Tais acordos têm como escopo o escoamento da produção e são firmados entre empresas que não concorrem, pois situadas em diferentes estágios da cadeia produtiva. 
No Brasil, o controle do direito concorrencial é informado pela Lei $\mathrm{n}^{\circ}$ 12.529/11. No que diz respeito ao contrato de distribuição, a atenção do direito antitruste recai, especialmente, sobre algumas cláusulas que podem produzir impactos anticoncorrenciais no mercado, chamadas de restrições verticais. É o caso, por exemplo, da exclusividade, das vendas casadas ${ }^{13}$ e da imposição de preços de revenda ${ }^{14}$.

Cumpre ressaltar, porém, que o trabalho não analisará os reflexos do inadimplemento recíproco à luz do direito antitruste. Em que pese à importância de investigar o contrato de distribuição sob uma dupla fonte normativa, o exame concentrarse-á nos efeitos produzidos pelo descumprimento recíproco nas relações estabelecidas entre as partes, priorizando, destarte, uma abordagem contratual.

\section{Propósito}

O escopo central do percurso investigativo é identificar as consequências do inadimplemento recíproco no contrato de distribuição, a fim de complementar o regramento legal que, a despeito de disciplinar o inadimplemento singular, nada esclareceu a respeito da inexecução por ambas as partes.

A adequada satisfação deste propósito reclama atenção para alguns pontos, os quais se apresentam como objetivos secundários. Pretende-se, deste modo, caracterizar os institutos envolvidos, quais sejam o contrato de distribuição e o inadimplemento recíproco.

O exame do referido contrato almeja contribuir para a formação de uma teoria geral do contrato de distribuição, a qual se prestará, substancialmente, a moldar o inadimplemento recíproco. A apreciação do inadimplemento recíproco, por sua vez, busca delimitar as situações abrangidas nesta figura e assim, definir seu conceito e âmbito de aplicação.

O trabalho pretende, ainda como objetivo secundário, identificar e examinar as consequências previstas no ordenamento jurídico para o inadimplemento singular das obrigações encontradas no contrato de distribuição. Acredita-se que tal exame fornecerá as bases teóricas necessárias para que, a seguir, sejam identificadas as consequências do inadimplemento recíproco do contrato de distribuição.

\footnotetext{
${ }^{13}$ Cf. Art. $36, \S 3^{\circ}$, inciso XVIII da Lei $12.529 / 11$.

${ }^{14}$ Cf. Art. 36, $\$ 3^{\circ}$, inciso IX da Lei $12.529 / 11$.
} 


\section{Método}

O direito comercial parte da observação dos fatos econômicos e do comportamento dos agentes, permanentemente abertos a inovações, para deles extrair seus princípios jurídicos. A contínua expansão dos mercados em economias dinâmicas tem propiciado o aparecimento de técnicas e mecanismos operacionais variados. Neste contexto, assume crescente importância o contrato de distribuição, destinado a viabilizar o escoamento da produção.

Com o propósito de oferecer uma resposta satisfatória aos objetivos traçados, forçoso é encarar o Direito como uma realidade histórica, aberto às mudanças da sociedade. É a partir dessa concepção que se almeja trabalhar o material, para se questionar se a legislação existente basta à disciplina das situações de inadimplemento recíproco.

Ao tratamento do tema proposto, faz-se necessário uma aproximação de dois ramos do direito privado, que, aliás, não são compartimentos estanques, mas sempre interrelacionados e interpenetrados, embora pautados por peculiaridades. Interessam a este trabalho o direito civil e o direito comercial, com destaque ao direito das obrigações e dos contratos.

O desenvolvimento da pesquisa será pautado pelo desiderato de oferecer uma resposta concreta ao problema do inadimplemento recíproco no contrato de distribuição. Trata-se, portanto, de um estudo destinado a aprimorar a dogmática e, portanto, passível de ser qualificado como pertencente à ciência jurídica, tomada em seu sentido mais estrito ${ }^{15}$.

\section{Estrutura}

Para a consecução dos objetivos que justificam o presente esforço teórico, propõese a divisão da pesquisa em duas partes: caracterização e consequências.

A Parte I pretende apreciar acuradamente as figuras envolvidas, quais sejam: o contrato de distribuição e o inadimplemento recíproco. Nada mais coerente, portanto, do que dividi-la em capítulos específicos destinados a caracterizar, respectivamente, o contrato de distribuição e o inadimplemento recíproco.

A Parte II, por sua vez, objetiva aferir as repercussões do inadimplemento, tanto singular quanto recíproco, do contrato de distribuição. Cumpre, com vistas a garantir maior

\footnotetext{
${ }^{15}$ Cf. Radbruch, Gustav. Filosofia do direito. Trad. L. Cabral de Moncada, 6 ${ }^{\mathrm{a}}$ ed. Coimbra: Armênio Amado, 1997. p. 395.
} 
clareza na exposição, investigar em um primeiro momento as consequências previstas para o inadimplemento singular das obrigações contratuais.

O exame do inadimplemento singular não basta, porém, para satisfazer os propósitos do presente percurso investigativo. Faz-se necessário ultrapassar o inadimplemento singular e observar que, na prática comercial, tornam-se cada vez mais corriqueiras situações em que ambos os contratantes não cumprem exatamente suas obrigações.

O último e derradeiro capítulo dedica-se, portanto, a aferir o sentido e os limites do inadimplemento recíproco, a fim de precisar suas consequências nos contratos de distribuição. Presta-se, em última medida, a complementar o regramento legal que, embora tenha disciplinado o inadimplemento, nada esclareceu sobre o descumprimento recíproco e tampouco sobre sua ocorrência nos contratos de distribuição.

\section{Regras de citação}

No corpo do texto, é feita apenas indicação ao número do dispositivo legal citado. As fontes, por sua vez, encontram-se transcritas na íntegra e conforme a redação original no item "Fontes Primárias".

Neste item, as fontes estão divididas conforme sua origem no direito ibérico antigo, no direito latino americano, no direito europeu, nos projetos de unificação ou em tratados internacionais. São, a seguir, organizadas por país e diploma legal, com o que se pode facilmente localizar o texto legal. As fontes alemãs sempre vêm acompanhadas da respectiva tradução para o italiano, em razão da maior proximidade deste idioma.

Os autores são citados pelo sobrenome que melhor os identifica, grafado em caixa alta, seguido pelo prenome, redigido em caracteres ordinários. A seguir, estão as referências da obra. O título está grafado em itálico e é seguido pelo volume, edição, local da publicação, editora e data. Cita-se também, quando pertinente, a página, separada por ponto final. Exemplo: AlviM, Agostinho. Da inexecução das obrigações e suas consequências. $5^{\mathrm{a}}$ ed. São Paulo: Saraiva, 1980. p. 80. Os patronímicos são considerados como sobrenome principal. Exemplo JUNQUEIRA DE AZEVEDO, Antonio. Negócio jurídico: existência, validade e eficácia. $4^{\mathrm{a}} \mathrm{ed}$. atual. de acordo com o novo Código Civil. São Paulo: Saraiva, 2002.

Nos trabalhos coletivos, citou-se o capítulo escrito pelo autor, o nome do coordenador e, em seguida, a referência da obra tal qual aclarado acima, seguida pela 
indicação das páginas pertinentes. Exemplo: Forgioni, Paula A. Tullio Ascarelli e os contratos de distribuição. In JunqueIRA DE AZEVEDo, Antonio; Torres, Heleno Taveira; Carbone, Paolo (coord.). Princípios do Novo Código Civil Brasileiro e outros temas Homenagem a Tullio Ascarelli. 2a ed. São Paulo: Quartier Latin, 2010.

Nas teses e dissertações, foi indicada a instituição de ensino na qual foi defendida. Exemplo: CAMILO Junior, Ruy Pereira. O contrato de distribuição: uma análise à luz da teoria relacional. Dissertação (mestrado em Direito) apresentada à Faculdade de Direito da Universidade de São Paulo, São Paulo, 2006. Os artigos publicados em revistas foram citados pela indicação do periódico grafado em itálico, local da publicação, volume, número de circulação, páginas e ano. Exemplo: GUERREIRO, José Alexandre Tavares. Aplicação analógica da lei dos revendedores. Revista de Direito mercantil, industrial, econômico e financeiro. São Paulo, v. 22, nº 49, p. 34-40, 1983.

Todas as referências bibliográficas são transcritas de modo completo na primeira nota de rodapé em que são citadas. Nas seguintes, aparecem de modo abreviado, com a indicação da página citada. Exemplo: PARDOLESI, Roberto. I contratti di distribuzione, op. cit., p. 156. Em adição, pode-se sempre consultar a bibliografia ao final.

As decisões judiciais foram citadas de acordo com o tribunal responsável, o tipo de feito, o órgão julgador, o relator e a data de julgamento. Todos os julgados consultados podem ainda ser conferidos ao final no item "Relação de Julgados Consultados".

As transcrições são feitas em aspas duplas e, em sua maioria, em notas de rodapé. Os conceitos também são citados entre aspas. As palavras em idioma estrangeiro são sempre citadas em itálico.

Como antecipado, a obra divide-se em duas partes, indicadas por algarismos romanos em negrito e redigidos em caixa alta. Os capítulos são indicados por algarismos arábicos em negrito e redigidos em caixa alta. Os títulos são precedidos por algarismos arábicos em negrito e redigidos ordinariamente. A maioria dos títulos apresentam subdivisões, as quais são indicadas pelo número do capítulo seguido por uma numeração em ordem crescente, tudo grafado ordinariamente. Pode-se sempre consultar o índice para controlar o modo de divisão da obra.

\section{Fomento}

O presente trabalho é fruto de pesquisa desenvolvida com o apoio financeiro e institucional da Fundação de Amparo à Pesquisa do Estado de São Paulo (FAPESP). 
PARTE I - CARACTERIZAÇÃO 


\section{CAPÍTULO 1 - O CONTRATO DE DISTRIBUIÇÃO}

\section{Introdução}

O contrato de distribuição, também conhecido como concessão comercial, é um dos principais instrumentos negociais concebidos para viabilizar o escoamento da produção, ao conectar a fase de produção ao consumo.

Este negócio assume destacada posição nos dias que correm, pois, com o aumento no volume da produção, tornou-se cada vez mais necessário o desenvolvimento de estruturas que assegurem a máxima difusão no mercado, ainda que em locais fisicamente distantes ou estanhos ao produtor.

Tais arranjos são estruturados para relações duradouras e o sucesso de referido negócio reclama esforços conjugados para a colocação dos produtos no mercado. As características deste tipo contratual, sobretudo seu enquadramento como um contrato de duração e de colaboração, colocam em xeque a adequação do regramento legal para disciplinar os problemas nele havidos.

Os conflitos entre as partes tendem a se acentuar diante do inadimplemento contratual. A situação torna-se ainda mais grave se ambos os contratantes descumprem o pactuado, o que, conforme cumpre ressaltar, é bastante corriqueiro nesta modalidade de negócio.

São situações como essa que o trabalho pretende investigar. Trata, deste modo, da caracterização e das consequências do inadimplemento recíproco nos contratos de distribuição.

Neste cenário, nada mais adequado do que principiar o percurso investigativo com o exame desta modalidade contratual. Pretende-se, com exatidão, contribuir para a formação de uma teoria geral do contrato de distribuição, a qual se prestará, oportunamente, a moldar o inadimplemento recíproco.

A análise tem como base teórica o plano de existência do negócio e, deste modo, busca precisar os elementos essenciais, naturais e acidentais do referido tipo contratual. Imperioso, para a correta qualificação, distinguir ainda o contrato de distribuição de outros que com ele guardam certa semelhança. 
Após a caracterização do contrato de distribuição, convém classificá-lo de acordo com algumas categorias, tais como a tipicidade, o tempo de duração da avença, a relação entre as partes, a forma de conclusão do negócio, a exigência da forma e a álea do negócio.

A classificação visa a definir o regime jurídico que será aplicado ao negócio e, assim, procura lançar as bases que auxiliarão na resolução dos problemas encontrados diante do inadimplemento recíproco dos participantes.

A qualificação do contrato de distribuição e a definição de seu regime jurídico não são suficientes, porém, para solucionar os problemas enfrentados diante do inadimplemento recíproco. Afinal, o descumprimento pode recair tanto sobre a obrigação principal, como sobre as obrigações relacionadas aos elementos particulares. Estas, por sua vez, podem desempenhar papéis distintos na economia do contrato.

Assim, quando ambas as partes descumprem suas obrigações, faz-se necessário, encontrar uma ferramenta que possibilite medir o inadimplemento de forma a determinar sua repercussão na economia do negócio. O capítulo, deste modo, estabelece uma gradação finalística dos elementos do contrato.

Precisar o que cada parte descumpriu é o primeiro passo a ser dado para que, na segunda metade do trabalho, se definam as consequências e a extensão das respectivas responsabilidades. Diante disto, cumpre principiar a caracterizar o contrato de distribuição por meio do exame da operação econômica que tal tipo negocial pretende abarcar.

\section{Operação econômica}

O processo de distribuição comercial tem como escopo reduzir a distância entre produção e consumo. A distribuição abarca uma série de operações dirigidas a fazer com que a mercadoria saia do produtor e alcance seu mercado de destino, o qual abrange tanto o consumidor quanto indústrias que empregam o bem em seu processo produtivo.

A finalidade mais ampla de toda atividade comercial é colocar bens no mercado. Ocorre que, com o aumento no volume da produção, tornou-se cada vez mais necessário o desenvolvimento de estruturas para o escoamento das mercadorias, de forma a assegurar a máxima difusão no mercado, ainda que em locais fisicamente distantes ou estanhos ao produtor.

A distribuição ocupa destacada posição na atual realidade econômica. É por meio dela que os produtos tornam-se disponíveis aos destinatários. O sucesso de um produtor, ainda que presentes qualidade e preço adequados, será bastante reduzido caso a mercadoria 
não alcance seu destino. O escoamento ineficiente, por outro lado, estrangula a demanda, levando os destinatários a procurarem alternativas que melhor se ajustem às suas necessidades.

O correto escoamento da produção, em quantidade, qualidade e preço adequados, não só satisfaz a procura pelo produto, como também desempenha papel fundamental quanto ao estímulo da própria demanda, por meio das atividades promocionais empreendidas. A distribuição, desta maneira, quando organizada de modo consistente, oferece importantes vantagens competitivas em relação aos concorrentes.

O processo distributivo, em suma, objetiva superar as lacunas existentes entre produção e destino. Costuma organizar-se sob duas modalidades: a distribuição direta e a indireta. Essas formas de distribuição aproveitam, porém, mais como abstrações conceituais do que realidades $\operatorname{concretas}^{16}$, já que o fornecedor não se encontra compelido a optar entre um ou outro método de maneira completamente apartada. Na prática, esforços próprios são combinados com a integração de empresários autônomos, em busca do máximo benefício ao sistema distributivo.

Na primeira modalidade, a própria empresa encarrega-se da distribuição, ou seja, os bens passam diretamente do produtor para o destinatário. Para tanto, além de sua atividade típica, o produtor cuida de todas as outras relativas à comercialização, através de filiais ou auxiliares dependentes.

A distribuição, no entanto, requer competências distintas daquelas necessárias à gestão dos processos produtivos. A atividade, em razão disso, foi progressivamente confiada a outros sujeitos que se dedicavam exclusivamente à comercialização. Houve, desta maneira, uma especialização no ramo de atuação dos agentes e o aparecimento da chamada distribuição indireta. Nela, o escoamento da produção é realizado por meio de uma cadeia de operadores, denominada canal de distribuição ${ }^{17}$.

Os canais de distribuição procuram estabelecer ciclos de circulação, em uma estrutura verticalmente concatenada, até que os produtos alcancem seu destino. A distribuição pode ocorrer em uma ou mais etapas (níveis), conforme o número de intermediários entre o produtor e o destinatário. Na cadeia constituída mais amiúde no que tange bens de consumo, figuram produtor, atacadista, varejista e destinatário. Quando o

\footnotetext{
${ }^{16}$ Cf. PARDOLESI, Roberto. I contratti di distribuzione. Napoli: Editore Jovene, 1979. p. 16.

${ }^{17}$ Cf. Ureba, Alberto Alonso; SAn Pedro, Luis Velasco; Ledesma, Carmen Alonso; Sáenz, Joseba Aitor Echevarría; GonZÁLEZ, A. Jorge Viera (dir.). Los contratos de distribución. La Ley: Madrid, 2010. p. 60.
} 
objeto são bens industriais, recorre-se comumente ao distribuidor industrial. Nada impede, deste modo, que os canais sejam organizados da maneira que mais aprouver às partes.

A distribuição indireta, por sua vez, divide-se em integrada e não integrada, consoante à inserção ou não do distribuidor na rede de distribuição criada e mantida pelo fornecedor ${ }^{18}$. Este se torna organizador de uma rede formada entre todos os seus agentes e tem a sua disponibilidade uma série de arranjos para estruturá-la, desde o mínimo de controle até a subordinação destes agentes. Por outras palavras, construir uma rede de distribuição confere ao fornecedor a possibilidade de influir, em maior ou menor grau, na comercialização das mercadorias ${ }^{19}$.

A disponibilidade do distribuidor em aceitar o vínculo pode ser incentivada através do oferecimento de uma série de vantagens, tais como financiamento, fornecimento de plantas, modelos de organização de empresa, uso de produtos em comodato, licença de uso de marca. O fornecedor, por meio dessa atuação, procura conferir ao distribuidor contrapartidas, a fim de que este aceite sofrer restrições em sua liberdade de atuação no momento em que ingressar na rede de distribuição ${ }^{20}$.

A distribuição, segundo as estratégias de cobertura do mercado, assume fundamentalmente quatro contornos. Trata-se da distribuição intensiva, seletiva, exclusiva e autorizada.

A distribuição intensiva consiste na utilização do maior número possível de pontos de vendas e, por conseguinte, é mais adequada para produtos de compra frequente e de baixo valor por unidade ${ }^{21}$. Contraposta à primeira, encontra-se a distribuição seletiva, na qual o produtor limita deliberadamente o número de intermediários comerciais.

Neste modelo, os fornecedores intentam controlar a distribuição e assegurar o prestígio da marca e a qualidade dos serviços por meio de uma rigorosa seleção dos revendedores. É adotada para produtos diferenciados, de luxo e de alta tecnicidade. Tendo em vista a natureza dos produtos, a presente estrutura é a que mais atende às necessidades do negócio. A colocação de mercadorias em grande quantidade ou aquela realizada fora de instalações adequadas teria o condão de vulgarizar produtos de luxo. Por outro lado,

\footnotetext{
${ }^{18}$ Cf. UREBA, Alberto Alonso (et. al). Los contratos de distribución, op. cit., p. 88.

${ }^{19}$ Cf. PARDOLESI, Roberto. I contratti di distribuzione, op. cit., p. 23-24.

${ }^{20}$ Cf. PARDOLESI, Roberto. I contratti di distribuzione, op. cit., p. 32.

${ }^{21}$ Cf. UrebA, Alberto Alonso (et. al). Los contratos de distribución, op. cit., p. 86.
} 
mercadorias de alta tecnicidade necessitam de distribuidores capazes de assegurar um eficiente serviço pós-venda ${ }^{22}$.

$\mathrm{Na}$ distribuição exclusiva, por sua vez, o distribuidor deve adquirir e revender unicamente os produtos do fornecedor. Tal modelo é bastante utilizado para produtos de marcas notoriamente conhecidas. A exclusividade de comercialização pode, eventualmente, estar acompanhada de acordo que estabeleça a exclusividade de zona de atuação, de maneira que não exista outro revendedor a atuar naquela área. $\mathrm{O}$ distribuidor autorizado, finalmente, não usufrui dessa delimitação territorial, mas goza do prestígio advindo do emprego do termo "autorizado" para atrair clientes ${ }^{23}$.

\section{Caracterização do contrato de distribuição}

O processo de distribuição é viabilizado, no campo jurídico, por contratos. Os contratos são a veste jurídica da operação econômica e servem, essencialmente, à criação e circulação de riquezas $^{24}$. O desenvolvimento de novos tipos contratuais pela autonomia privada responde a necessidades práticas.

No caso em tela, o incremento no volume da produção levou ao aparecimento de instrumentos negociais mais propícios a reduzir a distância entre produtor e destinatário. Estes arranjos possibilitavam a participação de terceiros na comercialização das mercadorias, o que não era viável nos esquemas tradicionais de troca ${ }^{25}$. Surgiram, deste modo, os contratos da distribuição.

Estes negócios, denominados ainda contratos em matéria de distribuição, são uma das mais importantes ferramentas de que dispõe o empresário para viabilizar o escoamento de sua produção ${ }^{26}$. Por meio deles, o fornecedor tem a colaboração de agentes independentes para a colocação de seus bens no mercado, o que permite àquele concentrarse na atividade produtiva e reduzir suas despesas e riscos.

\footnotetext{
${ }^{22}$ Cf. Monteiro, António Pinto. Direito comercial: contratos de distribuição comercial. Coimbra: Almedina, 2009. p. 115-116.

${ }^{23}$ Cf. PARDOLESI, Roberto. I contratti di distribuzione, op. cit., p. 85.

${ }^{24}$ Cf. RopPo, Enzo. O contrato. Coimbra: Almedina, 1988. p. 9. Faz-se relevante anotar que o capítulo atinente à função e evolução histórica do direito dos contratos, no qual consta o presente trecho, não se encontra nas edições posteriores da obra.

${ }^{25}$ Cf. SPINOZZI, Michele. La concessione di vendita. In VILlANACCI, Gerardo (org). I contratti della distribuzione commerciale. Torino: UTET Giuridica, 2010. p. 273; e MONTEIRO, António Pinto. Direito comercial: contratos de distribuição comercial, op. cit., p. 37.

${ }^{26}$ Cf. Forgioni, Paula A.. Contrato de distribuição. São Paulo: Editora Revista dos Tribunais, 2005. p. 29.
} 
O objeto de tais acordos é a intermediação econômica e, por conseguinte, disciplinam somente as relações entre fornecedor e distribuidor. Não interessa, portanto, o ato final de transmissão para o destinatário, mas a atividade desenvolvida a montante, isto é, a atividade de intermediação instrumental à outra ${ }^{27}$.

Os contratos da distribuição, em razão das necessidades cada vez mais complexas para a colocação dos produtos no mercado, assumiram uma série de contornos negociais. A evolução destes modelos, cunhados pela autonomia privada, dirigiu-se no sentido de acentuar cada vez mais a separação entre a fase da produção e a da distribuição. Neste sentido, encontram-se aqui a comissão, a agência, o contrato de distribuição propriamente dito e a franquia ${ }^{28}$.

É o contrato de distribuição propriamente dito o objeto central do presente trabalho. Tal negócio é também conhecido como contrato de concessão comercial, em razão de estudo de Requião ${ }^{29}$ que introduziu o termo na doutrina pátria, fortemente influenciado pela doutrina francesa ${ }^{30}$. Os termos contrato de distribuição e contrato de concessão comercial designam, assim, o mesmo tipo negocial ${ }^{31}$ de modo que, ao longo da investigação empregam-se indistintamente os vocábulos concedente e fornecedor; concessionário e distribuidor; bem como, distribuição e concessão comercial.

O contrato de distribuição é empregado no escoamento de ampla variedade de produtos, desde o setor de bebidas, vestuário, perfumes, eletrodomésticos, automóveis até produtos de elevada tecnologia e de luxo. Mais precisamente, instrumentaliza uma operação de distribuição indireta, a qual costuma organizar-se por meio de redes, apesar da possibilidade de arranjo não integrado.

O distribuidor se obriga a revender, em seu próprio nome e por sua conta, os produtos adquiridos junto ao fornecedor. Diferencia-se, porém, do comerciante comum, pois os revende conforme as orientações do concedente. Tais restrições na liberdade de

${ }^{27}$ Cf. MonTeIro, António Pinto. Direito comercial: contratos de distribuição comercial, op. cit., p. 35.

${ }^{28}$ É corrente na doutrina a inclusão destes tipos contratuais entre os contratos da distribuição. Cf. PARDOLESI, Roberto. I contratti di distribuzione, op. cit., p. 2; e MONTEIRO, António Pinto. Direito comercial: contratos de distribuição comercial, op. cit., p. 35.

${ }^{29}$ Cf. REQUIÃo, Rubens. O contrato de concessão de venda com exclusividade. Revista de Direito mercantil, industrial, econômico e financeiro. São Paulo, vol. 11, nº 7, p. 17-45, 1972.

${ }^{30}$ Cf. Champaud, Claude. La concession commerciale. Revue trimestrielle de Droit Commercial, Paris, n. 3, p. 451- 504, jul-set., 1963; e HEMARD, Jean. Les agents commerciaux. Revue trimestrielle de Droit Commercial, Paris, Tome XII, p. 573- 624, p. 1959.

${ }^{31}$ Neste sentido, Cf. Forgioni, Paula A. Contrato de distribuição, op. cit, p. 51 (nota 13) e p. 56-57; e Pollo, Marcelo. A discriminação de preço nas redes contratuais de distribuição. Dissertação (mestrado em Direito) apresentada à Faculdade de Direito da Universidade Federal do Rio Grande do Sul, Porto Alegre, 2011. Cumpre anotar a presença de entendimento diverso, segundo o qual a distribuição é uma espécie mais genérica de concessão comercial, conforme DINIZ, Maria Helena. Curso de Direito civil brasileiro: teoria das obrigações contratuais e extracontratuais. 27ª ed. São Paulo: Saraiva, 2011. p. 452. 
atuação são aceitas pelo revendedor em virtude, sobretudo, da possibilidade de ganho derivada do comércio dos artigos detidos por sua contraparte.

A remuneração do agente independente, tendo em vista a propriedade dos bens, é calculada com base na diferença entre o preço de aquisição e o de revenda. Trata-se, portanto, de contrato cuja função econômica primária é a comercialização por parte do distribuidor dos produtos do fornecedor ${ }^{32}$.

Além da obrigação de compra para a revenda, o contrato é geralmente acompanhado por outras obrigações. São cláusulas acessórias que disciplinam a relação entre concedente e concessionário e determinam, consequentemente, o nível de integração entre eles. Como o contrato tende a se estender no tempo, procura-se estabelecer as bases de um comportamento colaborativo entre as partes. Estas estipulações possibilitam que o fornecedor articule e coordene a distribuição de seus produtos, ainda que a atividade seja empreendida por outro.

Dentre as obrigações acessórias, vale mencionar a exclusividade de comercialização e de zona, a aquisição de cota mínima e a sugestão de preço de revenda. Podem-se estabelecer ainda regras sobre a organização, as instalações, os métodos de venda, as formas de publicidade e a prestação de assistência técnica a ser oferecida aos clientes.

O contrato de distribuição é, portanto, tipo complexo que reúne função de troca e de colaboração. O distribuidor, de fato, adquire as mercadorias do fornecedor, mas não as destina ao próprio consumo; seu fim é revendê-las. A atividade de revenda, por sua vez, é coordenada pelo fornecedor por meio de diversas cláusulas apostas no contrato. O êxito da operação contratual e, no extremo, da colocação dos produtos no mercado, depende da atuação de ambas as partes. Importante notar que conforme o arranjo negocial adotado no negócio concreto, o contrato poderá assumir configuração mais ligada à troca ou à cooperação.

Após esta descrição propedêutica da operação econômica e do contrato de distribuição, cumpre analisá-lo mais detidamente. Para tanto, a investigação vale-se do plano de existência do negócio jurídico como base teórica.

A exata caracterização do negócio é imprescindível para se moldar o inadimplemento, sobretudo quando o não cumprimento do pactuado se dá por ambos os contratantes. Neste caso, torna-se necessário identificar a relevância e a repercussão de

\footnotetext{
${ }^{32}$ Cf. Bortolotti, Fabio. Manuale di Diritto della Distribuzione. Vol. II, Padova: CEDAM, 2007.p. 2.
} 
cada obrigação descumprida para a economia do contrato e, em razão disto, o estudo do objeto do contrato de distribuição ocupará posição de destaque nas linhas que seguem.

Antes, porém, de se definir o conteúdo do contrato, afigura-se importante saber a qualidade das partes que realizam este negócio, posto que existem distintos regimes e interpretações para contratos civis, comerciais e de consumo. Definidos objeto e partes deste tipo negocial, o estudo recai, por fim, sobre a forma.

Cumpre ressaltar, porém, que não serão objeto de apreciação todos os elementos de existência, mas somente aqueles cujo exame revela-se fundamental para a elaboração de uma teoria geral do contrato de distribuição. Tratar-se-á, portanto, somente de objeto, partes e forma.

\subsection{Partes}

O contrato de distribuição é um contrato tipicamente empresarial. Entende-se por contrato empresarial aquele celebrado entre empresários (sociedades empresárias, empresários individuais ou empresa individual de responsabilidade limitada) e, consequentemente, sujeito aos princípios próprios do Direito Comercial. A doutrina, por vezes, emprega o termo interempresarial, o qual evidencia por si só a qualificação das partes e contrapõe-se ao negócio celebrado com empresa, no qual somente uma das partes ostenta tal natureza ${ }^{33}$.

Definir um tipo contratual como pertencente a esta categoria importa relevantes consequências, sobretudo para a interpretação e aplicação da lei civil unificada. Interpretar significa esclarecer o sentido daquilo pactuado pelas partes e um contrato empresarial requer lógica própria, diversa da aplicável aos contratos civis e aos contratos de consumo $^{34}$.

São partes desta modalidade contratual o fornecedor e o distribuidor. De um lado, tem-se o empresário que produz, fabrica ou fornece um bem, chamado genericamente de fornecedor. De outro, o distribuidor que adquire o produto daquele e atua em sua colocação no mercado. O contrato, como visto, pode também ser chamado concessão comercial e, adotada tal terminologia, tem-se, respectivamente, concedente e concessionário.

\footnotetext{
${ }^{33}$ Esta discussão é abordada em FORGIONI, Paula A. Teoria geral dos contratos empresariais, op. cit., p. 2829.

${ }^{34}$ Sobre a interpretação dos contratos empresariais cf. FORGIONI, Paula A. Interpretação dos negócios empresariais. In FERNANDES, Wanderley (coord.). Contratos empresariais: fundamentos e princípios dos contratos empresariais. São Paulo: Saraiva, 2007.
} 
A distribuição pode necessitar de uma, duas ou mais etapas para se concretizar. É possível que ocorra em apenas uma etapa, isto é, com a atuação de somente um distribuidor o produto é colocado em seu mercado de destino. Todavia, a cadeia distributiva, comumente, se estende, ao menos, a segunda etapa. Nesta situação, surge a figura do subdistribuidor encarregado de adquirir o produto do distribuidor e fazê-lo circular em seu respectivo mercado. Aqui, além daquele firmado entre fornecedor e distribuidor, há um contrato entre o distribuidor e o subdistribuidor, ou na linguagem comum, atacadista e varejista.

\subsection{Objeto}

O objeto de um contrato é o conjunto dos preceitos oriundos do consentimento ${ }^{35}$. É, de modo bastante simples, o conteúdo do contrato ${ }^{36}$. Ele deverá ser lícito, possível e determinado ou determinável, sob pena de nulidade.

A definição do objeto pode ser dada através dos elementos. A doutrina costuma operar uma classificação tripartida do conteúdo em elementos essenciais, naturais e acidentais $^{37}$.

Os elementos essenciais determinam a natureza jurídica de cada tipo de negócio. Eles acusam e distinguem o tipo do contrato. Os naturais, por seu turno, defluem da natureza do negócio, entretanto podem ser afastados mediante a vontade das partes e, em razão disso, são também denominados elementos categoriais derrogáveis. Os acidentais ou particulares, por fim, são apostos pelas partes e podem, por conseguinte, encontrar-se ou não presentes. Uma vez pactuados, todavia, compõem o objeto do contrato.

Para descrever juridicamente o contrato de distribuição, é, portanto, imprescindível examinar seus elementos. A correta definição da estrutura mínima do contrato facilitará, em última análise, o exame a ser empreendido no item 1.4, ao atuar como norte a ser

\footnotetext{
${ }^{35}$ Cf. BESSONE, Darcy. Do contrato: teoria geral. $4^{\text {a }}$ ed., São Paulo: Saraiva, 1997. p. 97.

${ }^{36}$ Cf. Carvalho de Mendonça, José Xavier. Tratado de Direito Comercial brasileiro. Vol. VI, Parte I. $6{ }^{\text {a }}$ ed. atual. Roberto Carvalho de Mendonça. Rio de Janeiro: Livraria Freitas Bastos, 1960. p. 87; e JUNQUEIRA DE AZEVEDo, Antonio. Negócio jurídico: existência, validade e eficácia, $4^{\mathrm{a}}$ ed., $6^{\mathrm{a}}$ tir., São Paulo, Saraiva, 2008. p. 32.

${ }^{37}$ A divisão dos elementos do negócio seguiu de perto o pensamento defendido por JUNQUEIRA DE AZEVEDO, Antonio. Negócio jurídico, op. cit., p. 31-41. Optou-se, no entanto, pelo emprego da terminologia tradicional, ainda que criticada pelo referido jurista, o qual os divide, respectivamente, em elementos categoriais inderrogáveis, categoriais derrogáveis e particulares. Ademais, para a explicação de cada um dos elementos, cf. VAsCOnCElos, Pedro Pais de. Contratos atípicos. Reimpressão da 1. ed. Coimbra: Almedina, 2002. p. 71-85.
} 
seguido na diferenciação de contratos que guardam semelhança com a concessão comercial.

Neste percurso cumpre, precipuamente, identificar quais os elementos cuja verificação é necessária e suficiente para que este tipo negocial exista. Em seguida, convém buscar aqueles que podem ser afastados pelas partes sem, contudo, alterar o tipo negocial. Assentados os elementos essenciais e naturais, deve-se, finalmente, perscrutar as estipulações mais frequentemente apostas pelos contratantes nesta modalidade contratual.

\subsubsection{Elementos essenciais}

Os elementos essenciais são imprescindíveis à caracterização do tipo negocial, o que os leva a ser denominados também como elementos categoriais inderrogáveis ${ }^{38}$. Ao analisar os elementos essenciais do contrato de distribuição, almeja-se identificar as características necessárias para que este negócio exista. Os "essentialia" representam, desta maneira, o objeto mínimo de um contrato. A ausência de apenas um deles, por outro ângulo, é suficiente para descaracterizar, excluir o negócio concreto do âmbito do contrato de distribuição. Na falta, o que existe é outro tipo contratual.

Para que a concessão comercial exista é necessário, primeiramente, que o distribuidor adquira os produtos do fornecedor. Não basta, porém, a compra, pois é imprescindível que os produtos não se destinem ao consumo, mas à revenda.

Trata-se, deste modo, de elemento essencial complexo, definido pela aquisição dos produtos do fornecedor pelo distribuidor para que este, posteriormente, promova, durante todo o tempo de duração da avença, a revenda em uma zona de atuação.

O correto entendimento da estrutura mínima do contrato reclama alguns esclarecimentos. A obrigação de compra das mercadorias do fornecedor pelo distribuidor é o primeiro ponto que merece atenção. A aquisição se concretiza por meio de inúmeras operações de compra e venda que se sucedem ao longo da vida do contrato e, desta maneira, não se confundem com operações meramente esporádicas.

Estas operações de compra e venda, todavia, não são negócios jurídicos autônomos, uma vez que consistem em execução do contrato de distribuição. Tais operações, mais

\footnotetext{
${ }^{38}$ Cf. JunQueIRA DE AZEVEDo, Antonio. Negócio jurídico, op. cit., p. 35.
} 
precisamente, assumem função instrumental ${ }^{39}$ em relação ao efetivo escopo perseguido pelas partes, qual seja a comercialização dos produtos no mercado ${ }^{40}$.

Da compra e venda ainda é possível depreender a transferência da titularidade das mercadorias, as quais saem do patrimônio do fornecedor e ingressam no do distribuidor. $\mathrm{O}$ concessionário torna-se, deste modo, proprietário do bem, o que será fundamental para distingui-lo do representante comercial e do comissário. Uma vez proprietário, atua em seu nome e por sua conta, assumindo os riscos do negócio de modo que sua remuneração é definida pela diferença entre o preço de aquisição e o preço de revenda dos produtos.

No que diz respeito às prestações do distribuidor, ao dever de adquirir os produtos, acrescenta-se a obrigação posterior de revenda. Esta prestação não lhe é exclusiva, uma vez que também se faz presente já na representação comercial. Somente na distribuição, porém, a revenda recai sobre produtos próprios, os quais são comercializados em nome e conta do distribuidor.

O fato de o concessionário possuir a titularidade das mercadorias faz com que tenha interesses próprios para colocá-las no mercado. O sucesso de sua própria atividade requer a comercialização dos produtos do fornecedor. É inegável, deste modo, que a atividade das partes é, em certa medida, convergente e a colaboração delas é preordenada (dirigida) ao êxito comercial dos mesmos produtos.

Neste cenário, a doutrina discute acerca da existência da obrigação de revenda a cargo do distribuidor. Questiona-se, de forma mais precisa, se esta obrigação é depreendida do próprio tipo contratual ou se descende apenas da efetiva vontade das partes ${ }^{41}$, hipótese em que sua existência depende da concordância do distribuidor.

A obrigação de revenda é elemento essencial do contrato de concessão comercial. Não há efetivamente distribuição caso o produto seja destinado ao próprio consumo. Por outro lado, o dever de revenda persiste ainda que não pactuado. Ocorre que, salvo estipulação expressa, não se pode reclamar a comercialização de uma quantia determinada

\footnotetext{
${ }^{39}$ Em acórdão, o Tribunal de Justiça do Estado de São Paulo corrobora a função instrumental das operações de compra e venda: "Quando falamos de contrato de distribuição, estamos diante de um contrato peculiar. Caem por terra, portanto, as opiniões que querem reduzir o contrato de distribuição a um negócio de compra e venda." (TJSP, Ap. Civ. no 1160584-0/0, $28^{\text {a }}$ Câm. Dir. Priv., r. Des. Júlio Vidal, j. 29.04.2008).

${ }^{40}$ Cf. BortolotTI, Fabio. Manuale di Diritto della Distribuzione, op. cit., p. 34; e NerVI, Andrea. I contratti di distribuzione tra causa di scambio e causa associativa. Napoli: Edizioni Scientifiche Italiane, 2011. p. 74 e 82.

${ }^{41}$ Uma parcela da doutrina sustenta que esta obrigação constitui elemento essencial do contrato ora em exame (Cf. PARDOLESI, Roberto. I contratti di distribuzione, op. cit., p. 279; e SPINOzZI, Michele. La concessione di vendita, op. cit., p. 272). Por sua vez, Bortolotti filia-se à posição contrária, conforme denota o seguinte excerto: "impegno del concessionario di promuovere le vendite non può risultare implicitamente dalla scelta del tipo contrattuale della concessione, ma deve discendere dall'effetiva volontà delle parti". (BORTOLOTTI, Fabio. Manuale di diritto della distribuzione, op. cit., p. 13).
} 
de produtos. É perfeitamente exigível, porém, que o distribuidor empreenda esforços para a comercialização. Trata-se, via de regra, de obrigação de meio.

As obrigações, conforme o exigido do devedor, costumam ser divididas pela doutrina em obrigações de meio e de resultado. Nestas, o adimplemento da obrigação requer a consecução de um resultado específico. Naquelas, por sua vez, o devedor obrigase tão somente a envidar esforços para atingi-lo; sua obtenção não é exigível, de modo que basta para o cumprimento que o resultado tenha sido adequadamente tentado ${ }^{42}$.

A orientação encontra também acolhida no art. 5.1.4 dos Princípios Unidroit, cujo texto toma o cuidado de esclarecer que nas obrigações de meio a diligência requerida corresponde àquela exigida na específica área e situação em que se coloca o devedor.

Neste sentido, o concessionário obriga-se a envidar seus melhores esforços no sentido de promover a venda dos produtos contratuais. Há obrigação meio de revenda e esta consiste em um elemento essencial da concessão comercial. Desta maneira, ainda que no negócio concreto as partes silenciem a respeito, ao distribuidor cabe agir com a diligência esperada na execução da prestação.

A bem da verdade, ainda que a obrigação do concessionário de promover a revenda constitua elemento essencial, provar a insuficiência de empenho é algo extremamente difícil. Esta prestação, em razão disso, costuma ser reforçada através das cláusulas de aquisição mínima e manutenção de estoque mínimo ${ }^{43}$. Tais cláusulas representam instrumentos manejados pelo fornecedor para controlar, em certa medida, a atuação e a diligência do distribuidor na colocação dos produtos no mercado.

Nada impede, entretanto, que as partes pactuem diferentemente e constituam uma obrigação de resultado. É possível, por exemplo, que o distribuidor se comprometa a vender no prazo de um ano a cota de 15.000 produtos em sua área de atuação. Nesta hipótese, caso venda apenas 6.000 artigos, há inadimplemento da obrigação contratual.

Esclarecida a obrigação de promoção de revenda, cumpre elucidar algumas questões relacionadas à zona de atuação. Existe necessariamente uma área em que o distribuidor executa suas atividades, independentemente de previsão contratual $^{44}$. Na maioria dos casos, tal região é individualizada no contrato.

\footnotetext{
${ }^{42}$ Cf. PEREIRA, Caio Mário da Silva. Instituições de direito civil. Vol. 2. 14. ed. rev. e atual. Regis Fichtner. Rio de Janeiro: Forense, 2010. p. 47-48; COMPARATO, Fábio Konder. Obrigações de meio, de resultado e de garantia. In FACHIN, Luiz Edson; TePEDINO, Gustavo José Mendes (coord.). Doutrinas essenciais - obrigações $e$ contratos. Vol I. Editora Revista dos Tribunais, 2011. p.73- 88; e CORDEIRO, António Menezes. Tratado de Direito Civil português. Vol. 2. Tomo I. Coimbra: Almedina, 2009. p. 443-454.

${ }^{43}$ Sobre estas cláusulas, conferir os itens $3.2 .3 \mathrm{c}$ e d, nesta ordem.

${ }^{44}$ Cf. Forgioni, Paula A. Contrato de distribuição, op. cit., p. 61.
} 
O problema surge exatamente quando o negócio nada dispõe sobre a zona de atuação e tampouco houve acordo verbal entre as partes. Neste caso, para se definir a área recorre-se a dados de fato, tal qual a região em que o distribuidor atuava anteriormente.

A ausência de delimitação clara, porém, é situação potencialmente conflituosa. De um lado, o concessionário não sabe com exatidão o quanto poderá expandir seus negócios. De outro, a indefinição gera dificuldades para caracterizar a falta do distribuidor na promoção da revenda.

Expostos os primeiros elementos essenciais do contrato de distribuição, cumpre, neste momento, investigar se a exclusividade e a subordinação também são elementos que definem este tipo negocial.

A exclusividade foi considerada por bastante tempo elemento essencial do contrato de distribuição ${ }^{45}$. Trata-se mais precisamente da exclusividade territorial, a qual assegura ao concessionário uma área exclusiva de atuação ao impedir a fixação de outros revendedores da mesma rede naquela determinada área.

Esta cláusula, em termos econômicos, é a mais simples e imediata contrapartida a ser oferecida para que o distribuidor aceite, primeiramente, empreender os esforços necessários para a revenda dos produtos e ainda ingressar na rede coordenada pelo fornecedor $^{46}$.

A exclusividade de zona de atuação consiste, de fato, em uma cláusula assaz recorrente. Não se trata, todavia, de elemento essencial, mas de elemento particular. Tal entendimento superou o anterior e é adotado atualmente tanto pela doutrina ${ }^{47}$, quanto pela jurisprudência ${ }^{48}$. No mesmo sentido, a Lei Ferrari, ao enfrentar o problema, estabeleceu, no parágrafo único de seu artigo $5^{\circ}$, que é inerente à concessão a definição da área operacional. Esta, no entanto, poderá conter mais de um concessionário da mesma rede.

A exclusividade não é depreendida pela simples escolha do tipo contratual e tampouco pode ser inferida da mera delimitação da zona de atuação ${ }^{49}$. Uma vez elemento particular, sua presença deve ser demonstrada, seja expressamente no documento

\footnotetext{
${ }^{45}$ A discussão sobre a essencialidade da exclusividade pode ser vista em Pardolesi. O autor, no entanto, não se filia à corrente e tece várias críticas: "l'idea che esclusiva catturi l'essenza dei contratti di distribuzione appare oggi inaccetabile"(Cf. PARDOLESI, Roberto. I contratti di distribuzione, op. cit., p. 223).

${ }^{46}$ Cf. PARDOLESI, Roberto. I contratti di distribuzione, op. cit., p. 156.

${ }^{47}$ Cf. Forgioni, Paula A. Contrato de distribuição, op. cit., p. 59; Bortolotti, Fabio. Manuale di Diritto della Distribuzione, op. cit., p. 19-22; e SPINOZZI, Michele. La concessione di vendita, op. cit., p. 285.

${ }^{48}$ Para o Tribunal de Justiça de São Paulo "a cláusula de exclusividade, em contrato de distribuição, deve ser cabalmente demonstrada” (TJSP, Ap. Civ. no 0220375-64.2002.8.26.0100, $21^{a}$ Câm. Dir. Priv., r. Des. Itamar Gaino, j. 02.06.2011).

${ }^{49}$ Cf. Forgioni, Paula A. Contrato de distribuição, op. cit, p. 202.
} 
contratual, por acordo verbal ou ainda através de uma situação de fato que evidencie essa escolha, como ocorre, por exemplo, quando a publicidade produzida pelo próprio concedente indica certo distribuidor como exclusivo ${ }^{50}$.

A ausência de elemento acidental, de outro lado, não descaracteriza o tipo. Qualificar-se como revendedor autorizado ou oficial já é, por vezes, contrapartida suficiente para o distribuidor, hipótese que claramente não afasta a existência de uma concessão comercial. No extremo, não desconfigura o contrato nem mesmo a colocação de novo distribuidor em um acordo que estipule a exclusividade. Há, neste caso, inadimplemento contratual, porém se mantém hígida a natureza da avença.

Portanto, muito embora a exclusividade territorial seja recorrente, ela não constitui elemento essencial. Trata-se, na verdade, de elemento acidental ou particular e, por isso, retomar-se-á sua descrição no item 3.2.3.a

O declínio da exclusividade como característica distintiva da concessão comercial encontra-se, consoante a doutrina, intrinsecamente relacionado com o aparecimento de novo entendimento. Segundo esta linha, é essencial a subordinação econômica do distribuidor, o qual se vê sensivelmente condicionado a seguir as políticas distributivas e escolhas comerciais do concedente ${ }^{51}$.

Este posicionamento é facilmente refutado nos dias de hoje, sobretudo quando se contempla os contratos firmados entre fornecedores e grandes varejistas. Nestes, o controle muitas vezes encontra-se nas mãos do distribuidor e a dependência é do fornecedor. Desta maneira, ainda que comum a subordinação, necessário perceber que a figura do concessionário abarca realidades muito distintas, que vão desde o grande empresário ao pequeno revendedor, o que impede de se definir esta característica como elemento essencial.

Por todo o exposto, conclui-se que é essencial para a existência do contrato de distribuição a aquisição dos produtos do fornecedor pelo distribuidor para que este, posteriormente, promova, ao longo de toda avença, a revenda em uma determinada zona de atuação. A ausência de apenas um desses elementos, no entanto, basta para descaracterizar a concessão comercial.

Precisado o elemento categorial inderrogável do contrato de distribuição, oportuno abordar seus elementos naturais e, posteriormente, os particulares.

\footnotetext{
${ }^{50}$ Cf. BortolotTI, Fabio. Manuale di Diritto della Distribuzione, op. cit., p. 22.

${ }^{51}$ Cf. PARDOLESI, Roberto. I contratti di distribuzione, op. cit., p.178-179.
} 


\subsubsection{Elemento natural}

Os elementos naturais defluem da própria natureza do negócio. As partes, no entanto, podem afastá-los, sem que isso acarrete a mudança de tipo negocial. Tais elementos, em razão disso, são também denominados categoriais derrogáveis ${ }^{52}$.

A permissão de uso da marca constitui o elemento natural do contrato de distribuição. Por meio desta obrigação, o fornecedor coloca o uso da marca à disposição do distribuidor, o qual poderá partilhar do prestígio e da notoriedade da marca para o exercício de sua atividade. O distribuidor assume, por sua vez, os deveres de zelar por ela e de atender às determinações do fornecedor quanto ao modo de usá-la. No extremo, a permissão de uso ainda possibilita que o distribuidor seja identificado como membro de sua respectiva rede pelo destinatário.

Como elemento natural, a permissão de uso da marca do fornecedor pelo distribuidor, em princípio, restará presente no contrato de distribuição. A vedação ao uso dependerá de manifestação dos contratantes, ou seja, há para as partes o ônus de se manifestar caso queiram afastá-lo.

De modo mais preciso, pode-se afirmar que a permissão de uso restará caracterizada ainda que as partes nada pactuem a respeito, o que a afasta de um elemento acidental. Para ilustrar tal situação, vale considerar um contrato de distribuição que tenha por objeto a revenda de bicicletas. Por meio dele, ainda que as partes nada tenham estabelecido, o distribuidor colocará no mercado produtos que estampem a marca do fornecedor.

O uso da marca, por outro lado, não figura entre os elementos essenciais do referido tipo negocial, porquanto a cláusula que o veda descaracteriza o contrato de distribuição. Nesta linha, basta pensar em uma cláusula cujo texto dispõe que as mencionadas bicicletas fornecidas pelo fornecedor serão colocadas no mercado com a marca do próprio distribuidor.

A permissão de uso da marca, deste modo, resulta do próprio contrato de distribuição e apenas não estará presente caso seja afastada expressamente no negócio concreto. Assim, este é o único elemento natural do contrato ora examinado.

\footnotetext{
${ }^{52}$ Cf. JunQueIRA DE AZEVEdo, Antonio. Negócio jurídico, op. cit., p. 38.
} 


\subsubsection{Elementos acidentais}

Os elementos acidentais ou particulares são aqueles inseridos no negócio concreto pelas partes no exercício da autonomia privada ${ }^{53}$. Eles não decorrem da mera escolha do tipo contratual e, com isso, sua presença requer estipulação das partes.

No contrato de distribuição, os elementos particulares assumem importante papel, ainda que ausente, por óbvio, conotação de essencialidade. Por meio deles, é disciplinada a relação entre concedente e concessionário e se determina, por conseguinte, o nível de integração entre eles ${ }^{54}$.

Estes elementos tencionam, mais especificamente, coordenar a atividade de revenda e articular a colaboração entre os contratantes. Possibilitam, em última análise, que o fornecedor controle sua rede de distribuição sem assumir, todavia, o risco de tal atividade, o qual recai sobre o concessionário. Trata-se, em suma, de regras internas de organização, apostas consoante a política comercial definida pelo fornecedor ${ }^{55}$. No negócio concreto, tais elementos podem ou não se encontrar e, uma vez presentes, podem aparecer com diversas configurações.

Cumpre, neste momento, identificar quais os elementos particulares apostos comumente no contrato de distribuição.

\section{a) Exclusividade territorial}

As cláusulas de exclusividade, aqui compreendidas a exclusividade territorial e de comercialização, são uma das mais recorrentes estipulações dos contratos de distribuição. Sua presença reforça a consecução dos objetivos perseguidos pelas partes nesta modalidade contratual, muito embora não constituam elementos essenciais.

A exclusividade territorial representa, de fato, a mais simples e imediata contrapartida a ser oferecida pelo fornecedor àquele cujo dever consiste em se empenhar ao máximo para a comercialização e a construção de um mercado para os produtos do outro. A exclusividade de venda, por outro lado, garante que o distribuidor concentrará todos os seus esforços na comercialização das mercadorias contratuais e, deste modo, é o principal instrumento para integrá-lo à rede de distribuição planejada pelo fornecedor ${ }^{56}$.

\footnotetext{
${ }^{53}$ Cf. JunQueIRA DE AZEVedo, Antonio. Negócio jurídico, op. cit., p. 38.

${ }^{54}$ Cf. SPINOZZI, Michele. La concessione di vendita, op. cit., p. 285.

${ }^{55}$ Cf. PARDOLESI, Roberto. I contratti di distribuzione, op. cit., p. 220 e MonTEIRO, António Pinto. Direito comercial: contratos de distribuição comercial, op. cit., p. 111.

${ }^{56}$ Cf. PARDOLESI, Roberto. I contratti di distribuzione, op. cit., p. 156; e BorTOlotTI, Fabio. Manuale di diritto della distribuzione, op. cit., p. 19-20.
} 
$\mathrm{Na}$ exclusividade territorial ou de zona, o concedente assume o compromisso de não vender as mercadorias objeto do contrato a outro distribuidor dentro de determinada área geográfica. $\mathrm{O}$ distribuidor com exclusividade, desta maneira, é o único autorizado a comercializar os produtos contratuais naquela região.

Note-se que a exclusividade não é inferida da mera delimitação da zona de atuação. É perfeitamente possível que se atribua uma área de atuação ao distribuidor sem concederlhe, no entanto, a garantia de não enfrentar a concorrência de outros distribuidores da mesma rede. A exclusividade, deste modo, deve ser pactuada por escrito no documento contratual, por acordo verbal ou ser depreendida através de uma situação de fato capaz de evidenciar a vontade das partes neste sentido. É o caso, por exemplo, de um panfleto publicitário produzido pelo fornecedor, no qual o distribuidor figure como exclusivo.

Esta exclusividade afasta a concorrência intramarcas e acaba por criar uma reserva de mercado a favor do distribuidor exclusivo ${ }^{57}$. Assim, o concessionário de determinada marca de relógios que atua com exclusividade em todo o território nacional é o único a colocar em nosso mercado os produtos contratuais. Ele se sujeita à competição com outras marcas (entremarcas), mas não à concorrência com integrantes de sua rede (intramarca).

Um dos principais problemas que envolvem a exclusividade a favor do distribuidor diz respeito à violação do contrato por parte de terceiros. Neste caso, não há venda direta e tampouco invasão territorial por outro da rede, mas uma comercialização à margem dos contratos estabelecidos com os concessionários exclusivos.

É o caso de terceiro que adquire o produto de dado fornecedor ou distribuidor e os revende na área de atuação de outro. A Lei $n^{\circ}$ 6.729/79, mais conhecida como Lei Ferrari, nos termos de seu artigo 12, procurou evitar esta situação ao vedar explicitamente a revenda de veículos novos pelo distribuidor a outros comerciantes. A comercialização paralela foi também alvo de apreciação pelo Superior Tribunal de Justiça ${ }^{58}$.

\section{b) Exclusividade de comercialização}

A cláusula de exclusividade de comercialização, também conhecida como exclusividade a favor do concedente, obriga o distribuidor a adquirir os produtos

\footnotetext{
${ }^{57} \mathrm{O}$ termo reserva de mercado é empregado por Nervi (NERVI, Andrea. I contratti di distribuzione, op. cit., p. 35). Por sua vez, Forgioni prefere dizer que há uma espécie de monopólio por não enfrentar a concorrência intramarca, mas somente a entremarcas (FORGIONI, Paula A. Contrato de distribuição, op. cit., p. 202).

${ }^{58}$ No caso, decidiu-se que o contrato de distribuição exclusiva, por si só, não anula a liberdade de comercializar produtos, decorrentes dos princípios que fundamentam a ordem econômica, nem afasta as regras de economia baseada na propriedade privada e na livre concorrência (Cf. STJ, REsp n ${ }^{\circ}$ 930.491, $3^{\mathrm{a}} \mathrm{T}$., r. Min. Sidnei Beneti, j. 12.04.2011).
} 
contratuais apenas do fornecedor (ou de outros por ele indicados). Por outras palavras, a cláusula veda que o distribuidor comercialize os produtos dos concorrentes, conforme reconhecido pelo Tribunal de Justiça de São Paulo ${ }^{59}$.

Vale esclarecer que a exclusividade de comercialização recai tão somente sobre os produtos contratuais. É possível que o negócio não abarque toda a gama de produtos do fornecedor, mas somente uma parcela deles. Neste caso, a limitação na atividade do distribuidor incide apenas sobre os produtos estipulados.

A situação é bem ilustrada por meio de um exemplo. Dada sociedade possui contrato de distribuição com famosa marca de relógios, sendo que uma de suas cláusulas prevê a exclusividade de comercialização. O contrato abrange, porém, apenas os modelos que suportam alta pressão, ou seja, aqueles destinados para mergulho. O distribuidor, portanto, não pode revender este tipo de relógio das marcas concorrentes. É livre, no entanto, para comercializar qualquer outro modelo.

A exclusividade de comercialização, como se conclui do exposto, liga-se à concorrência entremarcas e representa o principal instrumento detido pelo fornecedor para integrar o terceiro à sua rede de distribuição. Como o distribuidor assume a obrigação de comercializar apenas os produtos do fornecedor, esta cláusula tem o condão de aumentar a dependência econômica entre as partes.

\section{c) Aquisição mínima}

A cláusula de aquisição mínima (ou cota mínima) estabelece para o concessionário a obrigação de adquirir uma quantidade determinada de produtos em certo intervalo de tempo $^{60}$. O fornecedor, por sua vez, assume o dever de entregar a quantidade pactuada ${ }^{61}$.

Esta cláusula é frequentemente aposta pelas partes e, como visto, representa uma ferramenta para que o fornecedor controle a atuação e a diligência do partícipe na revenda dos produtos. Espera-se que o distribuidor empreenda os esforços necessários para colocar no mercado, ao menos, a cota que está vinculado a adquirir. A Lei Ferrari, nos termos de seu art. $7^{\circ}$, inciso III, estabelece critérios para a fixação da cota de aquisição, consoante a

\footnotetext{
${ }^{59}$ Segundo a decisão proferida, a "cláusula de exclusividade visa a manter a fidelidade do distribuidor ao fornecedor a fim de que não sejam comercializados produtos de empresas concorrentes." (TJSP, Ap. Civ. ${ }^{\circ}$ 992.05.123294-3, 26 ${ }^{\mathrm{a}}$ Câm., r. Des. Renato Sartorelli, j. 14.09.2010).

${ }^{60}$ Cf. TJSP, Ap. Civ. no 0111539-78.2008.8.26.0005, $31^{\text {a }}$ Câm., r. Des. Adilson de Araujo, j. 19.04.2011; e TJSP, Ap. Civ. no 108284-0/0, $36^{\text {a }}$ Câm., r. Des. Arantes Theodoro, j. 12.07.2007.

${ }^{61}$ A presença da obrigação de entrega de cota mínima também é exposta em CAMILO JÚNIOR. Ruy Pereira. $O$ contrato de distribuição: uma análise à luz da teoria relacional. Dissertação (mestrado em Direito) apresentada à Faculdade de Direito da Universidade de São Paulo, São Paulo, 2004. p. 76.
} 
capacidade empresarial, o desempenho de comercialização e a capacidade de mercado da área de atuação do concessionário.

Vale ressaltar, porém, que aquisição e revenda não se confundem e, em vista disso, é possível que o distribuidor descumpra sua obrigação de revenda, ainda que tenha adquirido a cota mínima fixada no contrato. Basta pensar em um concessionário que deixa de vender os produtos do concedente para, lançando mão da exclusividade territorial, excluí-lo do mercado.

\section{d) Manutenção de estoque mínimo}

A exigência de manutenção de estoque pelos concessionários reduz as despesas dessa natureza suportadas pelo concedente, uma vez que os custos com armazenagem, conservação e seguro são assumidos pelo primeiro.

Esta cláusula, tal qual a anterior, constitui instrumento detido pelo concedente para controlar a atuação e a diligência do distribuidor na colocação das mercadorias no mercado. Isto porque a presença de peças para reposição garante, em certa medida, que as necessidades dos destinatários serão atendidas. Ademais, a possibilidade de se encontrar todo o mix de produtos em qualquer dos distribuidores preserva a imagem da rede. No entanto, a ressalva feita anteriormente persiste, porquanto o distribuidor pode não se empenhar na comercialização dos artigos ainda que possua certo estoque.

Vale anotar, por fim, que o artigo 10 da Lei Ferrari limita as exigências de estoques no setor de veículos automotores de via terrestre.

\section{e) Serviço de assistência técnica}

Nos contratos de concessão mercantil, além da obrigação de promover a revenda, o concessionário geralmente tem o dever de prestar assistência técnica. Nos contratos que envolvem produtos de alta complexidade, como computadores, a capacidade para a prestação dos serviços de pós-venda constitui critério decisivo para o ingresso na rede de distribuição.

\section{f) Publicidade dos produtos}

As despesas com a publicidade dos produtos são, geralmente, partilhadas pelas partes. Na maioria dos casos, cabem ao distribuidor as ações de marketing local e ao fornecedor, aquelas de âmbito nacional ou que abarquem toda a sua rede. 
A ação publicitária da rede de distribuição é desenvolvida, mais precisamente, pelo fornecedor. O concessionário, deste modo, promoverá a propaganda de acordo com as diretrizes fixadas e costuma valer-se do material promocional (folders, adesivos, brindes) desenvolvido por sua contraparte.

\section{g) Orientações técnicas}

O fornecedor, como organizador da rede, prescreve ao distribuidor uma série de obrigações ligadas à política de vendas. As orientações comumente encontradas são aquelas relativas: (i) à um padrão mínimo de atendimento, até mesmo com o oferecimento de treinamento para pessoal; (ii) à organização das vendas e do estabelecimento; (iii) à forma de manuseio, acondicionamento e transporte das mercadorias até o destinatário e (iv) e à sugestão ou à indicação de parâmetros para a determinação do preço de revenda.

\section{h) Prestação de informações sobre o mercado}

O fornecedor, ao optar pelo sistema de vendas indireto, reduz também o seu contato com o mercado. A partir do momento em que é tomada tal decisão, as informações e percepções das demandas e reações dos destinatários chegam a ele somente por meio dos distribuidores ${ }^{62}$.

Esta situação justifica a presença da obrigação de prestar informações que recai sobre o distribuidor na grande maioria dos contratos.

\subsubsection{Usos e boa-fé}

As prestações acima tratadas compõem o objeto do contrato de distribuição. A aquisição dos produtos do fornecedor pelo distribuidor para que este, posteriormente, promova a revenda em uma zona de atuação, é obrigação complexa que define o tipo contratual e se estende pelo tempo de duração da avença.

O objeto contratual ora investigado não se limita, todavia, a estas obrigações. Merece destaque também a permissão de uso da marca a favor do distribuidor. Tal prestação, muito embora decorra do tipo, pode ser afastada mediante o consentimento das partes.

${ }^{62}$ Cf. PARDOLESI, Roberto. I contratti di distribuzione, op. cit., p. 27. 
O conteúdo do contrato é composto ainda por inúmeras outras obrigações que visam a organizar as atividades a serem empreendidas e a coordenar o relacionamento dos partícipes no iter contratual. As obrigações supra examinadas tratam-se daquelas mais frequentemente apostas pelas partes no exercício de sua autonomia privada.

O conjunto destes preceitos oriundos do consentimento compõem, portanto, o objeto do contrato de distribuição. Afigura-se imprescindível notar, entretanto, que a realidade, não raramente, excede as previsões das partes. A ocorrência de incompletudes contratuais é ainda mais natural quando os acordos são desenhados para terem longa duração, tal qual o contrato de distribuição. Os contratos de duração são feitos para protrair-se no tempo e, por isso, no momento de sua formação é impossível para as partes prever todos os eventos que podem ocorrer no futuro.

As lacunas devem ser supridas por meio da integração, sob pena de graves repercussões na economia do negócio. A integração objetiva criar normas para compor o conteúdo do negócio. As principais fontes de integração do contrato são o princípio da boa-fé objetiva ${ }^{63}$ e os usos em sua função normativa.

A boa-fé é elemento criador de novos deveres dentro da relação obrigacional. Tais deveres, fruto da complexidade intra-obrigacional, podem nascer e desenvolver-se independentemente de pactuação ${ }^{64}$. Os deveres resultantes da boa-fé objetiva são denominados na doutrina sob as mais variadas nomenclaturas: deveres acessórios de conduta $^{65}$; instrumentais ou funcionais ${ }^{66}$; e laterais ${ }^{67}$.

Nos contratos de colaboração, tais como o contrato de distribuição, a boa-fé, tomada nesta função criadora de deveres jurídicos, assume papel ainda mais destacado do que nos outros negócios jurídicos.

Nestes contratos, vários deveres fundados na boa-fé compõem, desde logo, o conteúdo do contrato. É o caso, por exemplo, do dever de informar. Assim, em razão da necessidade de colaboração entre os contratantes ínsita a tal negócio, os deveres de

\footnotetext{
${ }^{63}$ Segundo Roppo a boa-fé é uma importante fonte de integração dos contratos. Preceitua ainda que "non è azzardato dire che la scoperta e la valorizzazione di questo ruolo della buona fede costituisce una delle principali linee di sviluppo del diritto dei contratti del nostro tempo". (ROPPO, Vincenzo. Il contratto. $2^{\mathrm{a}}$ ed. Giuffrè Editore. Milano, 2011. p. 465).

${ }^{64}$ Cf. Couto E SILVA, Clóvis V. do. A Obrigação como processo. Rio de Janeiro: Editora FGV, 2006. p. 35. O trabalho foi originalmente apresentado em 1964, como tese de livre-docência.

${ }^{65}$ Cf. Antunes varela, João de Matos. Das obrigações em geral. V. I, $10^{\mathrm{a}}$ ed., $5^{\mathrm{a}}$ reimp. da ed. de 2000. Coimbra: Almedina, 2008. p. 123.

${ }^{66}$ Cf. MARTINS- COSTA, Judith. A boa-fé no direito privado: sistema e tópica no processo obrigacional. São Paulo: Editora Revista dos Tribunais, 1999. p. 438.

${ }^{67}$ Cf. SILVA, Jorge Cesa Ferreira da. A boa-fé e a violação positiva do contrato. Rio de Janeiro: Renovar, 2002. p. 75.
} 
consideração recíproca, de observância aos interesses da outra parte, em suma, de conduta honesta e leal, tornam-se ainda mais destacados conforme examinar-se-á mais detalhadamente no item 5.3. do presente capítulo.

Os usos e costumes também se prestam a completar a declaração negocial. O emprego dos usos e costumes na integração dos contratos já se encontrava na quinta regra de Pothier $^{68}$ e no art. 133 do Código Comercial. Nesse sentido, merecem destaque os arts. 1.374, do Código Civil italiano, e 1.135, do Código Civil francês, os quais estabelecem que os contratos obrigam não somente aquilo que neles está expresso, mas ainda a todas as consequências da obrigação decorrentes da equidade, dos usos ou da lei.

Note-se que, no contrato de distribuição, a função integrativa dos usos setoriais assume especial relevância ao produzir reflexos sobre o regime jurídico aplicável. A tipicidade social ${ }^{69}$ deste contrato prescreve que, na ausência de regramento particular, se recorra aos usos e costumes, para somente depois ter lugar a analogia a contratos semelhantes, conforme se examinará no item 5.1. do presente capítulo.

O princípio da boa-fé objetiva e os usos setoriais são, portanto, as principais fontes para integrar os contratos. No contrato de distribuição, o manejo correto de tais ferramentas contribuirá de maneira ainda mais destacada para definir o conteúdo do negócio e, consequentemente, permitirá promover a circulação e a criação de riqueza que justifica a tutela jurídica dos contratos empresariais.

\subsection{Forma}

Após empreender estudo sobre as partes e o objeto, cumpre, neste momento, examinar a forma do contrato de distribuição.

A forma é o meio pelo qual o agente expressa sua vontade ${ }^{70}$. Pode ser escrita, oral ou mímica. A declaração, em certas situações, pode resultar ainda do silêncio ou de um comportamento passível de ser valorado como declaração de vontade. Todo contrato,

\footnotetext{
68 "Régle pour l'interpretation des conventions: l'usage est d'une si grande autorité pour l'interprétation des conventions, qu'on sous-entend dans un contrat les clauses qui y sont d'usage, quoiqu'elles ne soient pas exprimées: In contractibus tacite veniunt ea quae sunt moris et consuetudinis."(POTHIER, Robert Joseph. Ouvres complètes de Pothier. Tome premier: Traité des obligations. Nouvelle édition. Paris: Chez Thomine et Fortic Libraires, 1821. p.88).

${ }^{69}$ Contrato socialmente típico é aquele que cuja tipicidade foi cunhada por seu retirado emprego pelo mercado, ou seja, o negócio foi de tal maneira difundido na praxe social e econômica que possibilitou o seu reconhecimento como um tipo negocial, em detrimento da ausência de regramento legal.

${ }^{70}$ Para aprofundamento sobre as funções desempenhadas pela forma no direito contratual brasileiro, cf. ZANETTI, Cristiano de Sousa. A conservação dos contratos nulos por defeito de forma. São Paulo: Quartier Latin, 2013, p. 159-218.
} 
manifestando-se por um ou outro meio, reclama uma forma ${ }^{71}$. Não há, de modo mais preciso, um negócio jurídico sem ela. A forma, portanto, é elemento de existência de todo negócio jurídico ${ }^{72}$.

No direito brasileiro, a escolha da forma é, em regra, livre. Não raro, porém, a lei exige a adoção de forma especial. Nesta hipótese, a forma específica, nos termos do art. 104 do Código Civil, assume a qualidade de requisito de validade e deve ser observada para que o negócio ingresse regularmente no mundo jurídico.

O contrato de distribuição, diferenciando-se dos chamados contratos solenes, não requer forma específica ${ }^{73}$. Encontra-se, mormente, sob a forma escrita, mas não há exigência de tal forma. Além disso, sua execução leva igualmente à formação do vínculo obrigacional por configurar aceitação tácita à proposta, conforme ensina a doutrina ${ }^{74}$, secundada pela jurisprudência ${ }^{75}$.

Conclui-se, assim, a caracterização do contrato de distribuição. Um contrato tipicamente empresarial, não solene, pelo qual o distribuidor adquire as mercadorias do fornecedor para, posteriormente empenhar-se na revenda, de acordo com uma série de regras que coordenam a atividade e, comumente, integram-no à rede.

\section{As diferenças em relação aos contratos afins}

No item anterior, o contrato de distribuição foi detidamente caracterizado. No entanto, para sua completa e exata compreensão, cumpre ainda diferenciá-lo de tipos negociais que guardam com ele alguma semelhança.

Nesta tarefa, deve-se anotar, primeiramente, a generalidade da expressão contratos de distribuição, a qual comporta duas acepções. O termo em seu sentido mais amplo

${ }^{71}$ Cf. RoPPO, Vincenzo. Il contratto, op. cit., p. 206.

${ }^{72}$ Cf. AzEVEDo, Antonio Junqueira de. JunQueIRA DE AZEVEdo, Antonio. Negócio jurídico, op. cit., p. 32.

${ }^{73}$ Posicionamento diverso é encontrado em Orlando Gomes. Segundo o autor, trata-se de contrato formal, cuja celebração deve se realizar por meio de instrumento particular (GoMES, Orlando. Contratos. $26^{\mathrm{a}}$ ed. atual. Antonio Junqueira de Azevedo e Francisco Paulo De Crescenzo Marino. Rio de Janeiro: Forense, 2009. p.464). O Tribunal de Justiça do Estado do Paraná, em linha, decidiu que "o contrato de distribuição só pode ser celebrado por escrito, sendo inaceitável o emprego da forma verbal em razão da complexidade das cláusulas e condições que devem integrar esse tipo de contrato" (TJPR, Ap. Civ. no 0124804-2, 1ª̂m. Civ., r. Des. Pacheco Rocha, j. 01.10.2002).

${ }^{74}$ Cf. GuERreiro, José Alexandre Tavares. Comentários sobre: Contrato mercantil. Proposta. Aceitação. Inexistência de manifestação expressa. Art. 1079 do CC. Silêncio circunstanciado que significa manifestação tácita da vontade. Cobrança procedente. Recurso não provido. Revista de Direito Mercantil, Industrial, Econômico e Financeiro, São Paulo, v. 23, no 53, p. 119-122, jan./mar. 1984.

75 "Contrato de distribuição. Parte que efetivamente atuava como distribuidora de produtos da ré. Contrato caracterizado, ainda que não escrito" (1 ${ }^{\circ}$ TACivSP, Ap. Civ. no 768.938-3, $2^{\mathrm{a}}$ Câm., r. Des. Cyro Bonilha, j. 18.08.1999). No mesmo sentido, STJ, REsp n 1.255.315, r. Min. Nancy Andrighi, j. 13.09.2011 e TJSP, Ap. Cív. no 7.029.588-8, 23 ${ }^{\text {a }}$ Câm. Dir. Priv., r. Des. Rizzatto Nunes, j. 05.03.2008. 
reporta aos contratos que visam a conectar, pelo sistema de venda indireta, a fase produtiva à distributiva. São ainda empregadas, a fim de evitar confusões terminológicas, as expressões contratos da distribuição ou contratos em matéria de distribuição. Aqui, encontram-se a agência (ou representação comercial), a comissão e a franquia.

O termo contrato de distribuição em sentido estrito, por sua vez, refere-se a uma das espécies abrangidas pelo gênero. Também conhecido como contrato de concessão comercial, este é o objeto do presente percurso investigativo.

O confronto do negócio ora objeto de estudo com outras figuras possibilitará o teste da exatidão dos elementos essenciais, naturais e acidentais traçados acima. Por meio da comparação, pretende-se, portanto, confirmar as características que definem o contrato de distribuição.

De modo mais preciso, pode-se afirmar que a comparação entre contrato de distribuição e, do outro lado, a agência, a comissão e ainda o contrato estimatório coloca em evidência a qualidade de proprietário do distribuidor.

A tarefa de estremar o contrato de distribuição da franquia afigura-se bastante árdua, mas, indubitavelmente, afasta a integração e a cooperação entre os partícipes como elemento definidor do tipo negocial ora tratado.

O cotejo com o contrato de fornecimento corrobora, por fim, que não basta a compra da mercadoria e, por conseguinte, demonstra a relevância da revenda para se definir o contrato de distribuição.

Por todo o exposto, não resta dúvida sobre a importância do presente item para a exata caracterização do contrato de distribuição. Cumpre, em virtude disso, ingressar, detidamente, em cada uma dessas comparações.

\subsection{Contrato de agência (representação comercial)}

O contrato de representação comercial rege-se pela Lei $n^{\circ} 4.886 / 65$. Com o advento do Código Civil de 2002 o contrato de agência foi disciplinado nos artigos 710 a 721 . A adoção de tal terminologia suscitou dúvidas na doutrina, porquanto se discute se agência e representação comercial são termos sinônimos ou se designam tipos contratuais diversos.

De acordo com o art. 710 do diploma civil, na agência uma pessoa assume, não eventualmente e sem subordinação, a obrigação de promover, à conta de outra, a realização de certos negócios em zona determinada e mediante remuneração. Por sua vez, consoante a Lei 4.886/65, exerce a representação comercial a pessoa não empregada que desempenha, 
não eventualmente e por conta de outra pessoa, a mediação para a realização de negócios mercantis, agenciando propostas ou pedidos, para transmiti-los aos representados ${ }^{76}$.

Das definições, resta claro que, independentemente da posição adotada, tanto agência quanto representação comercial não se confundem com o contrato de distribuição. Não obstante comunguem de vários traços semelhantes, saltam aos olhos características que os diferenciam.

O primeiro e mais relevante ponto a se considerar é a propriedade da mercadoria. A distribuição envolve a obrigação de transferência de propriedade do fornecedor para o distribuidor, para que este posteriormente revenda os produtos. $\mathrm{O}$ representante, ao contrário, em hipótese alguma adquire a propriedade dos bens. Ele atua tão-somente na captação de clientes para o proponente, sua atuação antecede a conclusão do contrato. A compra e venda da mercadoria se estabelece entre o representado e o adquirente. É aquele que assume, destarte, a responsabilidade contratual e o risco do negócio. Diz-se, em razão disso, que o agente atua em nome e por conta do outro.

Pode-se afirmar que o segundo traço diferenciador decorre do primeiro. Como não possui a propriedade do bem, é evidente que a remuneração do agente não resulta da diferença entre o preço de aquisição e o preço de revenda do produto, tal qual ocorre com o distribuidor. A retribuição do representante é calculada por meio de porcentagem ajustada a recair sobre o volume total de negócios alcançado, isto é, sob a forma de comissão ${ }^{77}$.

Importante destacar, por fim, a figura da agência-distribuição. Esta modalidade diferencia-se da agência pura, uma vez que nela, o representante tem à disposição a coisa a ser negociada, embora não tenha adquirido sua propriedade. A figura, porém, não se confunde com o contrato de distribuição, conforme se examinará no item 5.1.

\footnotetext{
${ }^{76}$ A diferença é apenas terminológica para Forgioni, Paula A. Contrato de distribuição, op. cit., p. 112; KROETZ, Tarcísio Araújo. As similitudes entre os contratos de agência e representação comercial. In JABUR, Giberto Haddad; PEREIRA Júnior. Antonio Jorge. Direito dos contratos. São Paulo: Quartier Latin, 2006. p. 472. Defendem, por sua vez, a existência de dois contratos REQUião, Rubens Edmundo. Os contratos de agência, de representação comercial e o contrato de distribuição. O art. 710 do Código Civil. In BUENO, J. Hamilton; MARTINS, Sandro G. Representação comercial e distribuição: estudos em homenagem ao prof. Rubens Requião. São Paulo: Saraiva, 2006. p. 189; e VenosA, Sílvio de Salvo. Direito civil: contratos em espécie. $11^{\mathrm{a}}$ ed. São Paulo: Atlas, 2011. p. 505.

${ }^{77} \mathrm{Na}$ mesma linha, o Tribunal de Justiça de São Paulo asseverou que "a distinção entre os dois tipos de contrato dá-se, preponderantemente, do seguinte modo: na representação comercial o representante ou agente desempenha sua função sem ter a disponibilidade dos bens ou coisas negociadas, agindo em nome e por conta da representada, a quem simplesmente apresenta os pedidos feitos pelos clientes, recebendo pelos serviços o que se chama "comissão"; enquanto que na distribuição o distribuidor dispõe dos bens, por tê-los adquirido junto à outra parte, o distribuído, obtendo lucro pela diferença entre os preços de compra e de revenda". (TJSP, Ap. n ${ }^{\text {0 }}$ 0220375-64.2002.8.26.0100, 21 a Câm. Dir. Priv., r. Des. Itamar Gaino, j. 02.06.2011).
} 


\subsection{Contrato de comissão}

O contrato de comissão é um contrato típico regulado pelos artigos 693 a 709 do Código Civil. Por meio deste, uma parte denominada comissário obriga-se a comprar ou vender bens em seu próprio nome, mas à conta de outrem - o comitente - em troca de certa remuneração.

O comissário compra ou vende mercadorias em seu próprio nome, obrigando-se perante as pessoas com quem contratar. A propriedade do bem, entretanto, é do comitente, o qual assume os riscos da mercadoria e emite instruções que devem ser seguidas pelo primeiro. A operação ocorre, deste modo, em nome do comissário e por conta do comitente.

Depreende-se, pois, que a diferença entre comissão e distribuição é patente e relaciona-se também com a propriedade da mercadoria. O comissário contrata em seu próprio nome, porém negocia produto que pertence ao comitente. Por tal atuação, o comissário recebe uma comissão e os proventos da venda destinam-se ao comitente.

Na distribuição, de outro lado, a obrigação de transferência da propriedade é elemento essencial. O distribuidor atua em seu nome e por sua conta e, por conseguinte, as receitas oriundas das vendas integram o seu proveito econômico.

\subsection{Contrato de franquia}

O contrato de franquia encontra-se tipificado pela Lei $n^{\circ} 8.955 / 94$. Esse contrato aproxima-se bastante do contrato de distribuição. Ambos são utilizados para facilitar o escoamento da produção e compõem o chamado sistema de distribuição indireta integrada. Ademais, o franqueado, tal qual o distribuidor, atua em nome e conta própria, de maneira a assumir inteiramente os riscos do negócio. Distingui-los, portanto, nem sempre se afigura uma tarefa fácil na prática ${ }^{78}$.

A franquia constitui uma evolução do contrato de distribuição quando se considera a crescente ingerência do franqueador na esfera de decisões do franqueado ${ }^{79}$. A maior intromissão na atividade é evidenciada pela presença de cláusulas como as seguintes: (i) o

\footnotetext{
${ }^{78}$ A dificuldade também é anotada por SPINOZZI, Michele. La concessione di vendita, op. cit., p. 277-279.

${ }^{79}$ Segundo a doutrina, a franquia representa um avanço qualitativo em relação ao contrato de distribuição, ao se considerar o esforço de o produtor se aproximar e intervir na fase de distribuição, utilizando-se, porém, somente de empresas independentes. (MonTEIRO, António Pinto. Direito comercial: contratos de distribuição comercial, op. cit., p. 125).
} 
franqueado tem a obrigação de controlar a limpeza e a manutenção da unidade quanto à fachada, estrutura, iluminação entre outros, zelando pela integridade da imagem do sistema de franquia; (ii) o franqueado deve periodicamente fornecer demonstrativos financeiros, bem como dados sobre o movimento comercial da unidade; (iii) ao franqueador, faculta-se inspecionar os estabelecimentos franqueados, inclusive sem aviso prévio ou autorização, a fim de manter a qualidade dos serviços prestados e preservar a integridade dos padrões do sistema de franquia.

Dentre os contratos da distribuição, o presente tipo é de fato aquele em que a integração entre as partes se dá no grau máximo e no qual a cooperação entre empresas independentes assume os contornos mais estreitos ${ }^{80}$, a ponto de a identidade dos sinais e da apresentação exterior gerar, aos olhos do público, a convicção de se tratar do próprio produtor ou de uma filial ${ }^{81}$.

Cumpre anotar, entretanto, que esta modalidade não se limita a uma técnica de escoamento da produção, diferenciando-se do contrato de distribuição. Ainda que o negócio comumente estipule a obrigação de venda de produtos do franqueador ao franqueado para que este os revenda, essa não é o elemento essencial do contrato de franquia. Destaca-se, assim, que a franquia pode conter o elemento categorial do contrato de distribuição, todavia, não se reduz a ele.

Isto fica ainda mais claro quando se leva em consideração a franquia de serviços, na qual se autoriza o franqueado a prestar serviços idênticos aos do franqueador, sob a insígnia e diretrizes deste. É o caso, por exemplo, de franquias de hotéis, de locadoras de automóveis, de lavanderias, entre outras. Não há obrigação de compra e venda de mercadorias; ocorre, na realidade, a disseminação de um modelo de negócio.

Este cenário também é encontrado nas denominadas franquias de produção ${ }^{82}$, dentre as quais se situam as franquias de restaurantes. Nestas, o franqueado não tem a obrigação de adquirir os produtos junto ao franqueador, porém deverá comprar os insumos necessários a elaboração destes junto à terceiros indicados ou credenciados pelo franqueador.

\footnotetext{
${ }^{80}$ Cf. UREBA, Alberto Alonso (et. al). Los contratos de distribución, op. cit., p. 70.

${ }^{81}$ Observa Pardolesi que o franqueado perde, de certo modo, a própria identidade ao "presentarsi agli occhi del pubblico secondo i canoni di un'imagine unitaria, alla stregua di una filiale del produttore" (Cf. PARDOLESI, Roberto. I contratti di distribuzione, op. cit., p. 86).

${ }^{82}$ Cf. UREBA, Alberto Alonso (et. al). Los contratos de distribución, op. cit., p. 70.
} 
Após a análise destas duas estruturas de negócios, resta evidente que a obrigação de aquisição de produtos do franqueador pelo franqueado não é essencial para que exista esta modalidade contratual ${ }^{83}$. O elemento categorial da franquia, como dito, é diverso.

A bem da verdade, para a existência do contrato de franquia, é necessária a presença dos seguintes elementos essenciais: (i) a utilização de marca ou sinais distintivos; (ii) a prestação de serviço de organização do local; (iii) e a transferência de métodos de operação do negócio (know-how comercial) ${ }^{84}$. Tais elementos podem ocorrer de forma mais ou menos intensa, não podem, porém, deixar de figurar, sob pena de inexistir um contrato de franquia, conforme alertado pela doutrina ${ }^{85}$.

Para melhor ilustrar, cumpre destacar como tais elementos figuram nos contratos. A prestação de serviço de organização se expressa de maneira mais evidente por meio do emprego de um padrão arquitetônico, o qual confere identidade visual interna e externa à rede de lojas. Pode, todavia, expressar-se de maneira menos intensa, refletindo-se, por exemplo, na arrumação das mercadorias e na alocação de corners e displays. $\mathrm{O}$ franqueador deve ainda prestar suporte na operação do negócio e, para tanto, costuma oferecer um esquema completo de organização empresarial, o qual abrange treinamento de pessoal, instruções para a compra de mercadorias e formação do estoque, organização contábil, sistema de software, prestação de consultoria para resolução de problemas, etc. $\mathrm{Na}$ franquia, são disponibilizadas ainda instruções relacionadas ao marketing, tais como o fornecimento de materiais promocionais e a realização de campanhas publicitárias.

De modo bastante simples, pode-se afirmar que o transferido na franquia é o direito de usar o modelo de empresa próprio do franqueador ${ }^{86}$. Comporta, assim, três aspectos consagradas pela doutrina por meio dos termos (i) marketing, (ii) engineering e (iii) management ${ }^{87}$.

Diante de todo o exposto, faz-se conveniente analisar uma questão com maior acuidade. Afirma-se, comumente, que franquia e distribuição assumem semelhante função

\footnotetext{
${ }^{83}$ Este posicionamento era adotado já por Comparato, o qual salientava o contrassenso em se considerar a venda de bens do franqueador ao franqueado como elemento fundamental deste contrato. Considerava haver, nesta hipótese, uma assimilação errônea da franquia à concessão de venda. (COMPARATO, Fábio Konder. Franquia e concessão de venda no Brasil: da consagração ao repúdio? Revista de Direito mercantil, industrial, econômico e financeiro, São Paulo, v. 16, no 18, p. 53-65, 1975. p. 55).

${ }^{84}$ Estes elementos são apontados por COMPARATO, Fábio Konder. Franquia e concessão de venda, op. cit., p. 53; BortolotTI, Fabio. Manuale di Diritto della Distribuzione, op. cit., p. 56-57; e UreBA, Alberto Alonso (et. al). Los contratos de distribución, op. cit., p. 70.

${ }^{85}$ É possível que, por exemplo, a importância da marca dos produtos comercializados sobreponha a transferência de know how envolvida no negócio concreto. Este é o caso apontado por Bortolotti envolvendo franquias da Benetton (BortolotTI, Fabio. Manuale di Diritto della Distribuzione, op. cit., p. 57).

${ }^{86}$ Cf. UREBA, Alberto Alonso (et. al). Los contratos de distribución, op. cit., p. 70.

${ }^{87}$ Cf. COMPARATO, Fábio Konder. Franquia e concessão de venda, op. cit., p. 54.
} 
econômica $^{88}$. A assertiva, embora essencialmente correta, comporta reflexão. A identidade ocorre, mais precisamente, entre franquia de produtos e distribuição. Há, em ambos, o abastecimento do terceiro integrado com produtos do fornecedor, favorecendo o escoamento da produção. É, de fato, esta modalidade que mais se aproxima do contrato de distribuição. A distribuição, por outro lado, não se presta a transferência de um modelo de prestação de serviço, distanciando-se da franquia de produção e de serviços.

Cumpre, por fim, ressaltar que determinadas estipulações constantes do contrato de distribuição tem o condão de aproximá-lo de maneira mais acentuada do contrato de franquia. É o caso, por exemplo, da permissão para o uso da marca e do dever de observância das orientações técnico-operacionais. Pode-se afirmar que quanto mais presentes obrigações que denotam maior integração e subordinação entre distribuidor e fornecedor, mais o contrato se aproxima da franquia.

\subsection{Contrato de fornecimento}

A diferença, neste caso, não reside na propriedade do bem, tal como ocorre em alguns dos contratos já mencionados. Tanto na distribuição quanto no fornecimento, há a transferência da propriedade ou, mais precisamente, a obrigação de transferência.

No contrato de distribuição, bens são adquiridos para a posterior revenda. No fornecimento, todavia, os produtos adquiridos destinam-se ao uso do próprio comprador ${ }^{89}$. A diferença está, em suma, no fim, no escopo do negócio.

\subsection{Contrato estimatório}

O contrato estimatório, também conhecido como contrato de consignação, é disciplinado pelos artigos 534 a 537 do Código Civil. Neste tipo contratual, o consignante entrega bens móveis ao consignatário. $\mathrm{O}$ consignatário pode vendê-los, pagando àquele o preço ajustado ou pode, se preferir, restituir a coisa consignada dentro do prazo estabelecido.

Importante notar que o consignatário detém apenas a posse do bem. Tal situação é evidenciada ao se permitir a restituição das coisas não vendidas, bem como ao se proibir a

\footnotetext{
${ }^{88}$ Cf. Forgioni, Paula A. Contrato de distribuição, op. cit., p. 104 e POLlo, Marcelo. A discriminação de preço nas redes contratuais de distribuição,op. cit., p. 116.

${ }^{89} \mathrm{Cf}$. REQUĩ̃o, Rubens. O contrato de concessão de venda com exclusividade, op. cit., p. 27.
} 
penhora ou sequestro da coisa consignada pelos credores do consignatário, conforme o artigo 536. A propriedade é do consignante até que se realize a venda, de modo que esta passará, caso realizada a venda, diretamente para o adquirente.

No contrato estimatório, o consignatário realiza em seu nome venda de produto que não lhe pertence. Deste modo, é bastante evidente sua maior proximidade com o contrato de comissão, distanciando-se da distribuição, a qual pressupõe a obrigação de transferência da propriedade das mercadorias do fornecedor para o distribuidor. $\mathrm{O}$ distribuidor outrossim assume todo o risco do negócio, sendo impossível restituir ao fornecedor as mercadorias das quais é proprietário, caso não as venda ${ }^{90}$.

A distinção entre o contrato de distribuição e o contrato estimatório encerra o item destinado a distinguir o negócio ora objeto de análise daqueles afins. Após caracterizar o contrato de distribuição e ainda estremá-lo de uma série de contratos que com ele guardam certa semelhança, o objeto deste tipo negocial encontra-se bem definido.

Não restam, assim, dúvidas sobre o que é um contrato de distribuição. Deste modo, tonar-se simples identificá-lo, ainda que as partes tenham conferido título diverso do contrato celebrado, chamando-o, como é comum na prática, de contrato de compra e venda mercantil e comodato de equipamentos, conforme demonstram alguns arestos do Tribunal de Justiça do Estado de São Paulo ${ }^{91}$.

Aclarado o conteúdo do contrato de distribuição, torna-se oportuno verificar as normas às quais este tipo negocial se submete, ou seja, determinar seu regime jurídico. Cumpre, para tanto, proceder a classificação do contrato de distribuição.

\section{Classificação do contrato de distribuição}

O presente item pretende identificar o regime jurídico aplicável ao contrato de distribuição, ou seja, propõe-se a aclarar as normas que regem este tipo negocial. A ferramenta disponível para tanto é a classificação ${ }^{92}$.

\footnotetext{
${ }^{90}$ Neste sentido, cf. FORGIONI, Paula A. Contrato de distribuição, op. cit., p. 110.

${ }^{91}$ Vale, a título exemplificativo, mencionar dois julgados do Tribunal de Justiça do Estado de São Paulo, nos quais as partes intitularam o contrato de distribuição, respectivamente, como "contrato de compra e venda mercantil e comodato de equipamentos" e "contrato de promessa de compra e venda mercantil e outros pactos" (Cf. TJSP, Ap. Civ. no 9230071-67.2008.8.26.0000, 35 a Câm. Dir. Priv., r. Des. Clóvis Castelo, j. 01.10.2012 e TJSP, Ap. Civ. nº 991.07.027294-0, 24 a Câm. Dir. Priv., r. Des. Salles Vieira, j. 05.05.2011).

${ }^{92}$ Cf. RoPPO, Vincenzo. Il contratto, op. cit., p. 411-412.
} 
Classificar um contrato significa enquadrá-lo em determinadas categorias dos negócios jurídicos. Vale anotar, a título exemplificativo, que os negócios jurídicos podem ser unilaterais ou bilaterais, comutativos ou aleatórios.

Ao se enquadrar dado contrato em categorias, serão aplicadas a ele as normas relativas a estas categorias, além daquelas próprias ao tipo e daquelas pactuadas pelas partes. Em adição, cumpre anotar que todo contrato, como exemplo mais típico de negócio jurídico, se sujeita ainda às normas deste.

Para a correta compreensão deste conjunto de normas a que se sujeita o contrato de distribuição, vale recordar que o negócio jurídico é uma abstração criada no campo jurídico. No caminho da abstração, parte-se do negócio concreto e se dirige a categorias cada vez mais genéricas, até chegar ao negócio jurídico ${ }^{93}$, como demonstra a ilustração abaixo:

Negócio individualizado

(Contrato de distribuição entre $A$ e B)
Contrato de

distribuição
Contratos em geral
Negócio jurídico

Vale recordar ainda que esta gradação coincide com a organização dos elementos de existência do negócio jurídico. Estes se organizam, de maneira gradual, em elementos gerais; elementos essenciais e naturais, também conhecidos como, respectivamente, elementos categoriais derrogáveis e inderrogáveis; e elementos acidentais (ou particulares). A visualização de tal correspondência é facilitada através da ilustração abaixo:

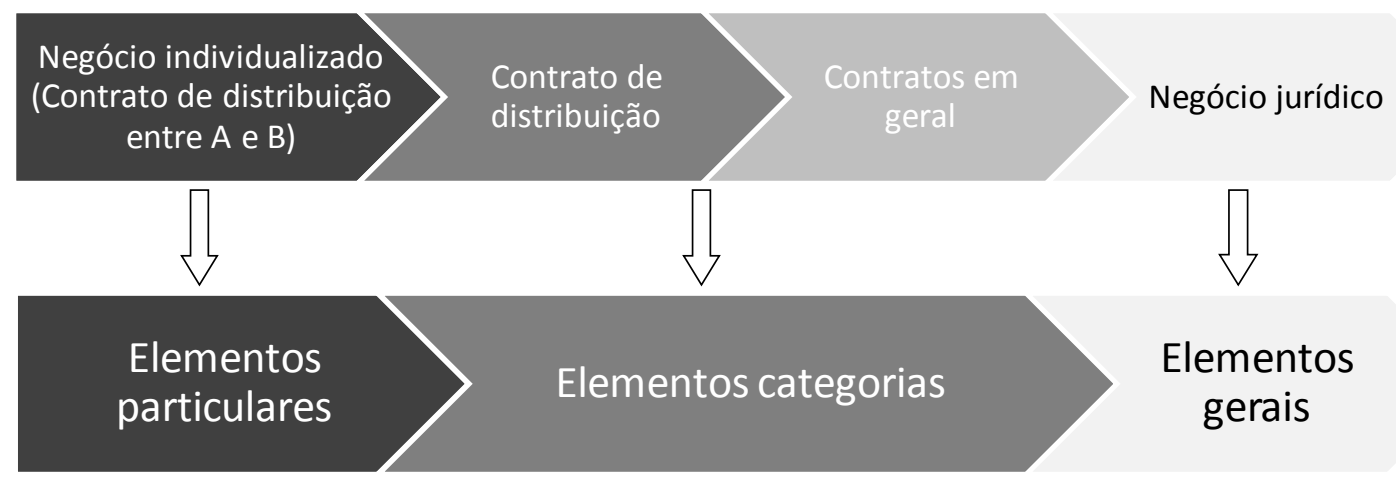

O item 3.2 do presente capítulo dedicou-se a identificar os elementos geralmente apostos pelas partes no contrato de distribuição, ou seja, os elementos particulares. Neste

\footnotetext{
${ }^{93}$ Cf. JunqueIRA DE AZEVEDO, Antonio. Negócio jurídico, op. cit., p. 31-32.
} 
mesmo item, foram sistematizados também os elementos essenciais e o elemento natural deste tipo negocial.

Neste cenário, falta apenas caracterizar o contrato de distribuição conforme as categorias dos contratos em geral. O enquadramento do contrato de distribuição em categorias possibilitará identificar os regimes jurídicos aplicáveis e facilitará ainda a compreensão de diversos problemas que se apresentam nestes contratos.

Nas linhas que seguem, portanto, o contrato de distribuição será classificado de acordo com as categorias que se apresentam como mais relevantes para a consecução dos fins do presente trabalho.

De modo mais preciso, pode-se afirmar que a classificação do contrato de distribuição como contrato socialmente típico afasta a incidência da Lei $n^{\circ}$ 6.729/79 nos negócios que não possuem como objeto veículos automotores.

O contrato de distribuição, como se analisará abaixo, pode ser classificado ainda como um contrato relacional e por adesão. É, no entanto, o enquadramento deste tipo como um contrato de duração e de colaboração que traz, indubitavelmente, consequências que mais de perto influenciam o presente trabalho.

Tal afirmação se explica, primeiramente, em razão das dificuldades havidas em um contrato de duração para se aferir a transformação da mora em inadimplemento definitivo. Em especial, tal enquadramento influi decisivamente na aferição da manutenção da utilidade da prestação para o credor.

Classificar o contrato de distribuição como um contrato de colaboração, por sua vez, traz consequências ao conteúdo do contrato, que poderá ser violado tanto mediante o descumprimento de um dever de prestação como de um dever lateral. A necessidade de colaboração entre as partes coloca em xeque ainda a efetividade de se recorrer à execução específica para sanar o descumprimento.

Por todo o exposto, não restam dúvidas sobre a importância do presente item para a definição do regime jurídico do contrato de distribuição, bem como para a solução dos problemas apresentados por tal tipo negocial. Cumpre, em virtude disso, analisar detidamente nas linhas que seguem como contrato de distribuição se enquadra nas categorias apontadas. 


\subsection{Contrato socialmente típico}

Os contratos podem ser classificados segundo a existência de disciplina legal. Não basta, porém, a existência de qualquer regulamentação. É necessário que se encontre em lei, ao menos, a disciplina básica do contrato. Logo, será típico aquele cujo tipo encontrase previsto e regulado em lei, ao passo que se diz atípico aquele cujo modelo jurídico não se encontra fixado em lei ${ }^{94}$.

A nomenclatura contratos típicos e atípicos prefere aos termos contratos nominados e inominados, apesar de identificadas por alguns como sinônimas ${ }^{95}$. Originalmente, o nomen juris equivalia ao tipo ${ }^{96}$. Nos dias que correm, entretanto, é salutar que se proceda a distinção entre as expressões.

Há inúmeros contratos que, embora designados em lei, não são objeto de regulamentação legal específica. É o caso, por exemplo, do swap, um modelo referido na legislação (Lei no 4.595/64 e 8.981/95, entre outras), mas que não detém satisfatório regramento. A distinção entre contrato nominado e inominado deve, portanto, ser reservada para casos em que o negócio possua ou não um nome. Os termos típicos e atípicos, de outro lado, reservam-se mais precisamente àqueles que tenham ou não disciplina própria ${ }^{97}$.

A discussão sobre a tipicidade da concessão comercial depende da análise de dois aspectos basilares. São eles: o capítulo intitulado "Da agência e distribuição" do Código Civil e a Lei ${ }^{\circ}$ 6.729/79, conhecida como Lei Ferrari.

O intérprete, ao se deparar com os artigos 710 a 721 do diploma civil, tem a impressão de que o contrato de distribuição é por eles disciplinado. No entanto, ao se examinar o regramento com maior cautela, nota-se uma realidade diferente.

O Código se refere ao contrato de agência e ao de distribuição. Não são tratados, porém, como tipos distintos. A lei civil, na verdade, refere-se sempre a agência, na qual se pode atribuir maiores ou menores funções ao agente. Surge, então, a figura da agênciadistribuição.

Esta modalidade diferencia-se da agência pura, pois o representante tem à sua disposição a coisa a ser negociada, embora não tenha adquirido sua propriedade. $\mathrm{O}$ agente,

\footnotetext{
${ }^{94}$ Cf. MARINO, Francisco Paulo De Crescenzo. Classificação dos contratos. In JABUR, Giberto Haddad; PEREIRA Júnior. Antonio Jorge. Direito dos contratos. São Paulo: Quartier Latin, 2006. p. 23-28.

${ }^{95}$ Cf. Antunes Varela, João de Matos. Das obrigações em geral, Vol I, op. cit., p. 272-273; e GoMES, Orlando. Contratos, op. cit., p. 119

${ }^{96}$ Cf. VASCONCElos, Pedro Pais de. Contratos atípicos, op. cit., p. 208.

${ }^{97}$ Cf. Vasconcelos, Pedro Pais de. Contratos atípicos, op. cit., p. 207-208; PereIRA, Caio Mário da Silva. Instituições de direito civil. Vol. 3. 14 a ed. rev. e atual. Regis Fichtner. Rio de Janeiro: Forense, 2010. p. 52.
} 
porém, continua a atuar em nome e por conta do proponente, o que torna esta figura diversa da concessão comercial, conforme afirmação recorrente na doutrina ${ }^{98}$ e que foi alçada à condição de enunciado na $1^{\mathrm{a}}$ Jornada de Direito Comercial, realizada em $2012^{99}$.

Não há, portanto, uma disciplina geral que trate do contrato de distribuição no Código Civil ou em outras leis esparsas. A ausência de regramento específico, todavia, não é total. A concessão comercial entre produtores e distribuidores de veículos automotores de via terrestre é típica, porquanto regulada desde 1979 pela Lei no 6.729 .

Em que pese a atipicidade legal, a distribuição é extremamente difundida na praxe social e econômica, dotada até mesmo de disciplina jurisprudencial. Neste cenário, deve-se considerar a possibilidade de enquadrá-la como um contrato cuja tipicidade tenha sido cunhada por seu reiterado emprego pelo mercado. Trata-se, sem dúvida, de contrato socialmente típico ou sócio-jurisprudencial ${ }^{100}$, consoante a categoria cunhada pela doutrina $^{101}$.

O reconhecimento da tipicidade social da distribuição gera importantes corolários. Reconhecer que a distribuição é tipo contratual afasta, em primeiro lugar, o seu enquadramento como contrato misto. $\mathrm{O}$ contrato misto forma-se pela combinação de elementos típicos de contratos diversos, sem que tal diversidade ofenda a unidade negocial concreta $^{102}$. A distribuição, com efeito, é reconhecida como tipo próprio e não como a reunião de elementos essenciais de outros.

\footnotetext{
${ }^{98}$ Cf. FORgIOnI, Paula A. Contrato de distribuição, op. cit., p. 111- 116; THEODORO JúNIOR, Humberto. Do contrato de agência e distribuição no novo Código Civil. Revista dos Tribunais, São Paulo, vol. 812, ano 92, p.22-40, jun. 03. p. 34. Cumpre anotar, contudo, a presença de entendimento diverso: CAMILO JÚNIOR, Ruy Pereira. Contrato de distribuição ou concessão mercantil. In JABUR, Gilberto Haddad; PEREIRA JÚNIOR. Antonio Jorge (coord.). Direito dos contratos. São Paulo: Quartier Latin, 2006. p. 456-457; TIMM, Luciano Benetti; Saboya, Lausiane Luz de. O contrato de distribuição no novo Código Civil. Revista Trimestral de Direito Civil, vol. 35, ano 35, p. 75-99, jul/set. 2008.

${ }^{99}$ Trata do Enunciado 31, cujo texto é o seguinte: "O contrato de distribuição previsto no art. 710 do Código Civil é uma modalidade de agência em que o agente atua como mediador ou mandatário do proponente e faz jus à remuneração devida por este, correspondente aos negócios concluídos em sua zona. No contrato de distribuição autêntico, o distribuidor comercializa diretamente o produto recebido do fabricante ou fornecedor, e seu lucro resulta das vendas que faz por sua conta e risco".

${ }^{100} \mathrm{O}$ contrato de distribuição é também qualificado como socialmente típico por ForGiONI, Paula A. Tullio Ascarelli e os contratos de distribuição. In JunQueIRA DE AZEVEdo, Antonio; TORRES, Heleno Taveira; CARbone, Paolo (coord.). Princípios do Novo Código Civil Brasileiro e outros temas - Homenagem a Tullio Ascarelli. $2^{\text {a }}$ ed., São Paulo: Quartier Latin, 2010. p. 519.

${ }^{101}$ Cf. MARINO, Francisco Paulo De Crescenzo. Classificação dos contratos, op. cit., p. 24; e RoPPO, Vicenzo. Il contratto, op. cit., p. 401.

${ }^{102} \mathrm{O}$ contrato misto pode ser ilustrado quando B cede o uso de um galpão para que A conserte seu caminhão e, em troca, A se compromete a transportar periodicamente as mercadorias de B. Reúnem-se, no caso, os elementos do contrato de locação e de transporte e formam uma unidade contratual. Vale anotar que o contrato misto (unidade contratual) não se confunde com os contratos complexos (unidade contratual com várias partes ou várias prestações) nem com os contratos coligados (pluralidade contratual). Cf. ROPPO, Vicenzo. Il contratto, op. cit., p. 405-407.
} 
A segunda consequência produz reflexos sobre o regime jurídico aplicável. A tipicidade social prescreve que, na ausência de regramento particular, se recorra aos usos e costumes, para somente depois ter lugar a analogia a contratos semelhantes.

A aplicação da analogia suscita discussão sobre os limites de incidência da Lei $\mathrm{n}^{\circ}$ 6.729/79. Faz-se oportuno analisar a possibilidade de se recorrer ao seu regramento para disciplinar outros negócios que não aqueles celebrados entre produtores e distribuidores de veículos automotores de via terrestre. Semelhante aplicação afigura-se bastante sedutora quando se tem presente que a Lei Ferrari estabelece uma série de regras para a resolução do contrato, tais como a aplicação de penalidades gradativas e a definição de critérios para aferição das reparações cabíveis, os quais poderiam servir de parâmetro para o estudo do inadimplemento recíproco.

Este raciocínio, entretanto, não se mantém quando submetido a crivo mais profundo. A analogia consiste em aplicar a uma hipótese não prevista em lei a disposição relativa a um caso semelhante. Funda-se no princípio da igualdade ao evitar que situações essencialmente idênticas sejam julgadas diversamente ${ }^{103}$. No âmbito dos contratos, seu uso deve sempre considerar o objetivo perseguido pelas partes, ou seja, deve-se recorrer à analogia apenas se seu emprego não puser em xeque a natureza do contrato efetivamente celebrado $^{104}$.

O devido exame evidencia que não há margem para a aplicação das regras da Lei Ferrari aos contratos de distribuição de outros setores, conforme posição secundada pela doutrina $^{105}$ e jurisprudência ${ }^{106}$. Não se pode, com efeito, aplicar uma norma jurídica senão

\footnotetext{
${ }^{103}$ Cf. MaXimiliano, Carlos. Hermenêutica e aplicação do direito. $20^{\mathrm{a}}$ ed. Rio de Janeiro: Forense, 2011. p. 169-171.

${ }^{104}$ Cf. ZANETTI, Cristiano de Sousa. Built to suit: qualificação e consequências. In BAPTISTA. Luiz Olavo. Construção Civil e Direito. São Paulo: Lex Editora, 2011. p. 118.

${ }^{105}$ Cf. GRAU, Eros Roberto; ForgionI, Paula A. Restrição à concorrência, autorização legal e seus limitesLei 8.884, de 1994, e Lei 6.729, de 1979. Revista Trimestral de Direito Público. São Paulo, vol. 21, nº 107, p. 107-121, 1998; e Forgioni, Paula A. Contrato de distribuição, op. cit., p. 93.

${ }^{106}$ A inaplicabilidade da Lei 6.729/79 é o entendimento adotado na maioria das decisões. Cf. STJ, REsp n ${ }^{\circ}$ 654408, $4^{\mathrm{a}}$ T., r. Min. Fernando Gonçalves, j. 09.02.2010; REsp n ${ }^{\mathrm{o}}$ 789.708, $3^{\mathrm{a}}$ T., r. Min. Nancy Andrighi, j. 25.09.2006; REsp n ${ }^{\mathrm{o}}$ 681100, $3^{\mathrm{a}}$ T., r. Min. Carlos Alberto Menezes Direito, j. 19.06.2006; REsp no 88.565,

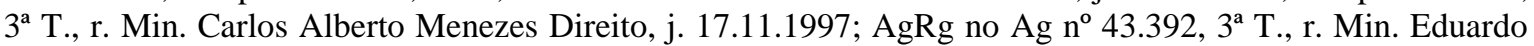
Ribeiro, j. 15.03.1994. Os Tribunais de Justiça seguem a orientação adotada no STJ, conforme demonstram os arestos a seguir: TJSP, Ap. Cív. no 9195569-78.2003.8.26.0000, 13ª Câm. Dir. Priv., r. Des. Zélia Maria Antunes Alves, j. 24.08.2011; TJSP, Ap. Cív. n ${ }^{\circ}$ 1.237.997-0, 12 ${ }^{\mathrm{a}}$ Câm. Dir. Priv., r. Rui Cascaldi, j. 11.07.2007; e TJSC, Ap. no 2007.033186-5, $3^{\mathrm{a}}$ Câm. Dir. Com., r. Des. Domingos Paludo, j. 02.07.2010. Cumpre anotar, todavia, a presença de julgados em sentido contrário: TJPR, Ap. nº 0139236-7, $8^{\text {a }}$ Câm., r. Des. Campos Marques, j. 20.08.2003 e TJRS, Ap. no 70002672095, $9^{a}$ Câm., r. Des. Ana Lúcia Carvalho Pinto Vieira Rebout, j. 30.04.2003.
} 
à ordem de coisas para a qual foi estabelecida ${ }^{107}$ e a Lei Ferrari é diploma concebido para a realidade da distribuição de veículos automotores de via terrestre.

É com efeito difícil conceber que a distribuição de bebidas, por exemplo, assemelha-se essencialmente à distribuição de automotores de tal modo a autorizar a analogia. A semelhança, porém, é clara, subsistindo igual lógica, quando se tem em conta a distribuição de pneus ${ }^{108}$.

\subsection{Contrato de duração}

Quanto ao tempo de realização das prestações, os contratos dividem-se em contratos de execução instantânea e contratos de duração. Contratos de execução instantânea são aqueles nos quais a execução ocorre de uma só vez. Eles se subdividem em contratos de execução imediata e de execução diferida.

Nos contratos de execução imediata, o cumprimento das prestações tem lugar logo em seguida à celebração do negócio, como se dá, por exemplo, na compra e venda de um livro em dado estabelecimento comercial.

Nos contratos de execução diferida, por sua vez, permite-se que o adimplemento ocorra em um segundo momento, embora pudesse ser realizado desde logo. O decurso do tempo, deste modo, é tolerado pelos contratantes. O exemplo mais corriqueiro é a compra e venda a prazo. Nela, as partes entendem conveniente diferir a execução ao longo do tempo para viabilizar a operação econômica, embora pudessem preferir, se dispusessem dos meios para tanto, executar desde logo as respectivas prestações.

O decurso do tempo, diversamente, é essencial ao cumprimento dos contratos de duração, ou seja, o prolongamento da relação contratual é essencial para que as partes possam obter as vantagens que justificaram a contratação do negócio. É o caso, por exemplo, do contrato de locação.

Nos contratos de duração, o adimplemento é, assim, protraído no tempo, posto que ao menos uma das prestações não se exaure instantaneamente e demanda certo lapso temporal ${ }^{109}$. Bipartem-se, por seu turno, em contratos de execução continuada e de execução periódica.

\footnotetext{
${ }^{107}$ Cf. MaXimiliano, Carlos. Hermenêutica e aplicação do direito, op. cit., p. 173.

${ }^{108}$ Cf. Guerreiro, José Alexandre Tavares. Aplicação analógica da lei dos revendedores. Revista de Direito mercantil, industrial, econômico e financeiro. São Paulo, v. 22, nº 49, p. 34-40, 1983.

${ }^{109}$ Sobre esta classificação, cf. MARINO, Francisco Paulo De Crescenzo. Classificação dos contratos, op. cit., p. 31-33.
} 
A locação se presta a exemplificar perfeitamente a categoria. Sob o ponto de vista da obrigação do locador, trata-se de um contrato de execução continuada, pois a cessão do uso e fruição do bem permanece ao longo de todo o contrato. Sob o ponto de vista da obrigação do locatário, trata-se de um contrato de execução periódica, pois o aluguel é pago de tempos em tempos, sendo normalmente mensal.

Nos contratos de execução instantânea, o cumprimento da obrigação põe fim ao vínculo. Nos contratos de duração, por outro lado, o adimplemento de uma obrigação reforça o vínculo, pois a cada prestação adimplida surge uma nova a ser cumprida no futuro. Basta pensar novamente no contrato de locação, no qual longe de extinguir a relação contratual, o pagamento do aluguel faz com que as partes continuem a ser credoras e devedoras uma da outra.

O contrato de distribuição pertence à categoria dos contratos de duração, nos quais os interesses negocialmente deduzidos projetam-se no tempo. Figura, mais especificamente, entre os contratos de execução continuada, sob a perspectiva da maior parte das obrigações, embora também contenham obrigações de execução periódica, como a entrega dos produtos e o respectivo pagamento. O tempo de duração da relação jurídica, por sua vez, pode ser determinado ou indeterminado, conforme o pactuado.

A estabilidade do negócio no tempo é do interesse de ambas as partes. Ao fornecedor, a continuidade da relação possibilita que construa uma rede eficiente de terceiros encarregados em comercializar suas mercadorias. Por outro lado, a garantia da duração, representa um estímulo para que o distribuidor promova os investimentos necessários para o adequado desenvolvimento da atividade de revenda ${ }^{110}$. Pode-se afirmar, desta maneira, que contrato de distribuição é feito para durar no tempo ${ }^{111}$.

Este contrato efetivamente ganha significado somente se considerado em sua dimensão temporal. As operações de compra e venda realizadas entre fornecedor e distribuidor se protraem no tempo com a finalidade de instrumentalizar a atividade de colocação dos produtos no mercado. Pode-se dizer que o contrato é tão útil para as partes quanto maior for o tempo que ele durar, em verdade, quanto mais tempo, mais utilidade.

Uma vez que o negócio foi concebido para se estender no tempo, as partes necessariamente irão conviver por certo período. Em vista disso, a consecução plena da finalidade do contrato e a consequente satisfação dos interesses das partes exigem e, de

\footnotetext{
${ }^{110} \mathrm{O}$ enquadramento do contrato de distribuição na categoria dos contratos de duração é devidamente analisado por NERVI, Andrea. I contratti di distribuzione, op. cit., p. 66-74.

${ }^{111}$ Cf. NERVI, Andrea. I contratti di distribuzione, op. cit., p. 70.
} 
fato, dependem da cooperação e colaboração existente entre as partes. Por outras palavras, significa dizer que o comportamento colaborativo emerge, em certa medida, do próprio contrato de duração $^{112}$.

A duração do avença produz ainda reflexos no próprio conteúdo do negócio. Como é impossível prever, no momento da formação do contrato, todos os eventos que podem ocorrer no futuro, os usos e a boa-fé, tomados em sua função integrativa, assumem destacado papel na definição do conteúdo do negócio ao longo de todo íter contratual, preenchendo o que falta na estrutura contratual e adaptando o negócio às novas realidades.

O enquadramento do contrato de distribuição como um contrato de duração produz importantes consequências na presente pesquisa, uma vez que identificar a transformação da simples mora em inadimplemento definitivo nos contratos de duração não representa uma tarefa fácil.

A manutenção ou a perda da utilidade, para o credor, da prestação descumprida é situação de difícil identificação em um contrato que irá se estender no tempo. O tempo, deste modo, interfere diretamente na valoração da utilidade da prestação. Não há exagero, portanto, em dizer que esta classificação afigura-se como uma das mais relevantes ao presente trabalho.

Cumpre anotar, por fim, que os contratos de duração estão sujeitos à aplicação resolução por onerosidade excessiva, desde que observados os pressupostos legalmente exigidos para tanto.

\subsection{Contrato de colaboração}

A concessão comercial pode ser classificada ainda como um contrato de colaboração. Neste, presumem-se esforços conjugados, partes patrimonialmente autônomas e que mantêm áleas interdependentes e distintas. Este modelo contratual surgiu da necessidade de se evitar problemas intrínsecos à celebração de uma série de contratos de intercâmbio desconectados, bem como da fuga à rigidez dos esquemas societários ${ }^{113}$.

A progressiva universalização da economia, na segunda metade do século XX, ensejou o aumento no uso desta categoria de contratos. De fato, a vinculação entre

\footnotetext{
${ }^{112}$ No mesmo sentido, cf. NeRVI, Andrea. I contratti di distribuzione, op. cit., p. 71.

${ }^{113}$ Cf. Forgioni, Paula A. A evolução do direito comercial brasileiro: da mercancia ao mercado. São Paulo: Editora Revista dos Tribunais, 2009. p. 165.
} 
empresas não mais ocorre somente por meio de participação societária de capital, adotando também a forma de uma rede de contratos estáveis ${ }^{114}$.

Estes acordos diferem dos contratos de intercâmbio (ou permuta). Em ambas as categorias, os contratantes encontram-se animados por interesses contrapostos. Ao contratar as partes buscam algo que não possuem para a satisfação de suas necessidades. Em uma compra e venda, o vendedor quer obter dinheiro, desfazendo-se da coisa; e o comprador almeja a coisa, abrindo mão do dinheiro. Nota-se que para um contrato existir, as diferenças entre as partes são essenciais, e se refletissem interesses paralelos tampouco haveria contrato ${ }^{115}$.

Nos contratos de distribuição, a multiplicidade de interesses pode ser evidenciada, por exemplo, na delimitação da zona de atuação. O crescimento da demanda pelo produto faz com que o fornecedor se interesse pela colocação de novos distribuidores em certa região, com vistas ao aumento no volume de vendas, uma vez que enfrenta a concorrência com outras marcas no mercado (entremarcas). Por sua vez, o aumento do ganho do fornecedor pode representar diminuição no volume global de vendas do antigo distribuidor, o qual enfrentará, além da entremarcas, a concorrência com o novo distribuidor (intramarca).

Ocorre que, em um contrato de colaboração, além dos interesses contrapostos, encontram-se interesses comuns. A sua estrutura, portanto, é fundamentalmente diversa daquela vista em um contrato de intercâmbio, uma vez que os contratos de colaboração amparam-se em uma cooperação estrutural.

Note-se que, nos contratos de distribuição, os interesses das partes, em última análise, convergem em busca do sucesso na colocação do produto no mercado de destino. O contrato de distribuição é, deste modo, negócio em que convivem interesses comuns e divergentes. Muito embora empresário não subordinado que atua em seu próprio nome e conta e assume os riscos de seu negócio, o distribuidor abre mão de parcela de sua autonomia ao sujeitar-se às orientações do fornecedor. Busca, com isso, beneficiar-se do mercado de que dispõem os produtos contratuais e, com isso, maximizar seus ganhos. A relação entre concedente e concessionário é marcada, portanto, por uma tensão, fruto da coexistência de interesses comuns e outros contrapostos.

\footnotetext{
${ }^{114}$ Cf. COMPARATO, Fábio Konder. Estado, empresa e função social. Revista dos Tribunais, São Paulo, $\mathrm{n}^{\circ}$ 732, p. 38-46, 1996. p.40.

${ }^{115}$ Cf. ANTUNES VARELA, João de Matos. Das obrigações em geral, Vol I, op. cit., p. 217.
} 
Analisar a distribuição como um contrato de colaboração faz emergir particularidades próprias do emprego desta categoria ao colocar em evidência a presença de partes que possuem interesses comuns e outros conflitantes e a necessidade, em razão da duração do negócio, de se estipular uma disciplina que assegure a convivência duradoura e colaborativa entre as partes.

A necessidade de se disciplinar a convivência colaborativa entre as partes produz consequências diretas sobre o conteúdo do contrato. Nos contratos de colaboração, deveres comumente caracterizados como anexos integram diretamente o contrato. É o caso, por exemplo, do dever de informar.

O inadimplemento recíproco também revela particularidades desta categoria de negócio. Nos contratos de colaboração muitas vezes as prestações das partes não têm relação de interdependência. Não são, portanto, razão de ser um das outras, mas verdadeiros instrumentos para que a finalidade do negócio, de interesse de ambas as partes, seja atingida.

Mais importante que o eventual intercâmbio, é o resultado para ambas as partes em caso descumprimento. Em tais contratos, o proveito está relacionado à sua execução global, sem que se reduza, entretanto, à consideração de uma e outra prestação.

Na compra e venda, o cumprimento do contrato depende do pagamento do preço e da transferência do bem, ou seja, de que cada parte cumpra a respectiva prestação. No contrato de distribuição, diferentemente, a consecução dos objetivos do contrato depende de que cada parte colabore para que a outra posse bem executar a prestação que lhe toca, isto é, os participantes têm interesse na execução do outro e vice-versa.

A título ilustrativo, a vinculação de uma peça publicitária infeliz pelo fornecedor pode colocar em xeque a venda de produtos e, consequentemente, a possibilidade de ambas as partes lucrarem com a celebração do negócio.

A necessidade de colaboração para o sucesso da avença frente ao descumprimento do pacto por ambos os contratantes põe em xeque também a viabilidade de se aplicar as prescrições constantes da legislação quanto à execução específica, conforme se examinará mais adiante.

\subsection{Contrato relacional}


O contrato de distribuição pode também ser entendido como um contrato relacional $^{116}$. Essa categoria, pensada por juristas norte-americanos, representa uma tentativa de renovação da dogmática contratual nos direitos de família romano-germânica, ao colocar luz sobre contratos de duração e acordos com cláusulas abertas ${ }^{117}$.

São relacionais os contratos de duração que têm por objeto a colaboração ou ainda aqueles que a exigem intensamente para poder atingir seus fins, tal como a distribuição e a franquia $^{118}$.

Nos contratos relacionais, a construção da relação se estende ao longo da vida do negócio, uma vez que o contrato é pensado para se protrair no tempo. A incompletude é pressuposto desta categoria contratual. A estrutura do contrato, no momento de sua celebração, é incompleta de modo a autorizar constantes complementações ao longo da execução do negócio, adaptando-se às novas realidades. Esses contratos, desta forma, não disciplinam apenas as trocas a realizar-se entre as partes, mas todo o relacionamento delas ao longo do iter contratual.

Qualificar o contrato de distribuição como relacional salienta o papel da lealdade e da confiança como base da relação contratual, posto que a preservação do vínculo por certo tempo depende intimamente do comportamento das partes. Para a correta compreensão dessa afirmação, cumpre examinar brevemente a boa-fé. A boa-fé objetiva, prevista como cláusula geral no artigo 422 do Código Civil, assume, segundo a doutrina, três papéis. Deste modo, é cânone interpretativo; representa limite ao exercício de direitos subjetivos; e atua na criação de deveres jurídicos, como o de informar ${ }^{119}$.

Nesta última função, a exigência de boa-fé varia conforme o tipo de contrato e isso é bem observado no contrato relacional ${ }^{120}$. Em razão da acentuação do elemento pessoal, da necessidade de colaboração e do caráter aberto do contrato relacional, o princípio da boa-fé objetiva deve ser mais intensamente considerado nessa categoria do que nos

\footnotetext{
${ }^{116}$ Cf. CAMILO JÚNIOR, Ruy Pereira. O contrato de distribuição: uma análise à luz da teoria relacional, op. cit., p. 129-132.

${ }^{117}$ Cf. JUNQUEIRA DE AZEVEDO. Antonio. Natureza jurídica do contrato de consórcio. Classificação dos atos jurídicos quanto ao número de partes e quanto aos efeitos. Os contratos relacionais. A boa-fé nos contratos relacionais. Contratos de duração. Alteração das circunstâncias e onerosidade excessiva. Sinalagma e resolução contratual. Resolução parcial do contrato. Função social do contrato (parecer). In Novos estudos e pareceres de direito privado. São Paulo: Saraiva, 2009. p. 354.

${ }^{118}$ Cf. JUNQUEIRA DE AZEVEDO. Antonio. Natureza jurídica do contrato de consórcio. Classificação dos atos jurídicos quanto ao número de partes e quanto aos efeitos. Os contratos relacionais, op. cit., p. 355-356.

${ }_{119}$ Cf. MARTins-CostA, Judith. A boa-fé no direito privado, op. cit., p. 427-428.

${ }^{120}$ Cf. JUNQUEIRA DE AZEVEDO. Antonio. Natureza jurídica do contrato de consórcio. Classificação dos atos jurídicos quanto ao número de partes e quanto aos efeitos. Os contratos relacionais, op. cit., p. 356.
} 
negócios não relacionais ${ }^{121}$. Esta exigência, portanto, reflete-se diretamente na distribuição e trará certamente consequências quando se examinar o inadimplemento de ambas as partes.

\subsection{Contrato por adesão ou negociado}

Os contratos, segundo o modelo de sua formação, costumam distinguir-se em contratos negociados e contratos por adesão ${ }^{122}$. Nos primeiros, como evidencia o próprio nome, o conteúdo contratual é formado pela composição livre e negociada das partes.

Nos contratos por adesão, de outro lado, há predisposição de cláusulas. É possível que, eventualmente, se discuta uma ou outra cláusula secundária, o que não afasta sua caracterização como contrato por adesão. A nota fundamental é não haver margem para a discussão do conteúdo fundamental da avença ${ }^{123}$. No campo do direito privado, inclusive nas relações entre empresários, são comuns os contratos por adesão. São exemplos a franquia, o financiamento bancário, o arrendamento mercantil, o transporte, entre outros praticados cotidianamente no mercado.

O contrato de distribuição é tipo a ser acrescentado à lista acima. Sua formação ocorre, mormente, por meio de adesão. Este modo de conclusão do negócio é utilizado especialmente quando se pretende uniformizar as condições contratuais e a atuação dos vários distribuidores no âmbito de uma rede. Este modelo de formação contratual é o mais adotado, portanto, na organização de redes contratuais de distribuição ${ }^{124}$. A padronização dos contratos é tão característica ao tipo contratual que chega a ser exigida pela Lei Ferrari, nos termos de seu art. 20.

Esta situação realmente não poderia ser distinta ao se considerar uma rede. Há um ganho de eficiência no sistema de distribuição ao se buscar a uniformidade na atuação dos membros. Evita-se a ocorrência de atuações díspares e, por vezes, sem um padrão mínimo de qualidade. A eventual diversidade de estipulações, ademais, poderia enfraquecer todo o

\footnotetext{
${ }^{121}$ Cf. MARINO, Francisco Paulo De Crescenzo. Classificação dos contratos, op. cit., p. 45; e ForgionI, Paula A. Contrato de distribuição, op. cit., p. 75.

${ }^{122}$ Necessário esclarecer, desde já, que contrato por adesão e contrato de consumo não são termos coextensivos. Para consulta dos grupos de contratos existentes atualmente no direito brasileiro, ver ZANETTI, Cristiano de Sousa. Direito contratual contemporâneo: a liberdade contratual e sua fragmentação. São Paulo: Método, 2008.

${ }_{123}^{123}$ Cf. ZANETTI, Cristiano de Sousa. Direito contratual contemporâneo, op. cit., p. 228-229.

${ }^{124}$ Neste sentido, cf. MonteIRO, António Pinto. Do regime jurídico dos contratos de distribuição comercial. Revista brasileira de Direito comparado, $\mathrm{n}^{\circ}$ 22, p. 33-49, $1^{\circ}$ sem. 2002. p. 37; SCHERKERKEWITZ, Iso Chaitz. Contratos de distribuição e o novo contexto do contrato de representação comercial. São Paulo: Editora Revista dos Tribunais, 2011. p. 87.
} 
processo de distribuição ao gerar disputas internas entre os distribuidores e entre estes e o fornecedor.

A possibilidade de elaborar o texto contratual permite ao predisponente transferir ao aderente os riscos que não lhe interessa assumir. Na maioria das ocasiões, conforme ressalta a doutrina, nota-se que as obrigações do fornecedor se limitam praticamente ao fornecimento dos produtos e ao reconhecimento de um direito de exclusividade ao distribuidor. Este, por sua vez, assume uma série de obrigações, tais como aquisição mínima de produtos, manutenção de estoque, realização de investimentos mínimos e participação nas despesas com publicidade ${ }^{125}$.

Os contratos por adesão, justamente para tutelar o equilíbrio entre os direitos e deveres das partes e coibir abusos, sujeitam-se a algumas regras. A primeira encontra-se prevista no art. 423 do Código Civil e estabelece que, em casos de contradições e ambiguidades, deve-se adotar a interpretação mais favorável ao aderente.

Estes negócios sujeitam-se ainda a regra de controle de conteúdo presente no artigo 424 do Código Civil, a qual dispõe que o aderente não pode renunciar aos direitos inerentes à natureza do negócio.

Imperioso notar, porém, que o conteúdo deste tipo contratual, em muitos casos, pode ser negociado. Nesta hipótese, tanto a interpretação quanto o controle de conteúdo do contrato de distribuição são disciplinados pelas regras aplicáveis aos negócios jurídicos em geral.

É comum a negociação das cláusulas quando se trata do primeiro distribuidor. Basta que se pense no distribuidor que inicia a comercialização de certo produto no mercado brasileiro. O poder econômico do distribuidor é outra situação que poderá ocasionar a negociação das cláusulas da avença.

O contrato de distribuição pode formar-se, assim, por adesão ou por negociação. Ele qualifica-se ainda como contrato socialmente típico, de duração, relacional e colaborativo. Estas categorias encontram-se intrinsecamente ligadas, conferem à concessão comercial seu delineamento geral e terão notável repercussão na definição de seu regime jurídico.

\footnotetext{
${ }^{125}$ Conforme alerta BortolotTI, Fabio. Manuale di Diritto dela Distribuzione, op. cit., p. 10.
} 


\subsection{Outras classificações}

O contrato de distribuição, sem maiores problemas, é ainda classificado como consensual, não solene, bilateral, oneroso e comutativo ${ }^{126}$ ao se adotar como critério, respectivamente, a formação do contrato, a exigência da forma, a eficácia do pactuado, o fluxo patrimonial e a álea do negócio.

A classificação aqui empreendida permite enquadrar o contrato de distribuição com vistas à definição de seu regime jurídico. A classificação, no que mais de perto interessa ao presente trabalho, serve a lançar as bases para solucionar os problemas advindos do inadimplemento contratual, especialmente no que se refere às características que emergem de seu enquadramento como um contrato de duração e de colaboração.

\section{Gradação finalística dos elementos}

Após descrever juridicamente o contrato de distribuição, cumpre empreender uma nova divisão de seus elementos. No itens anteriores, definiu-se o que é essencial para a existência deste tipo contratual. Estabeleceu-se ainda quais são os elementos que, embora não essenciais, assumem importância decisiva para a organização e coordenação da relação entre as partes e da atividade de revenda.

Esta diferenciação não basta, porém, para estabelecer a disciplina aplicável ao inadimplemento recíproco. Quando ambas as partes descumprem suas obrigações, faz-se necessário encontrar uma ferramenta que possibilite medir o inadimplemento de forma a determinar sua repercussão na vida da avença. De maneira bastante simples, o primeiro passo a ser dado é precisar o que cada um descumpriu, para, mais adiante, definir a repercussão para o vínculo jurídico e a extensão das respectivas responsabilidades.

O descumprimento da obrigação principal é de capital importância e, portanto, tende a influir de modo decisivo na definição das consequências próprias ao inadimplemento recíproco. Sua consideração, todavia, não é suficiente para dirimir as questões que gravitam em torno do inadimplemento recíproco. Afinal, o descumprimento pode recair tanto sobre a obrigação principal, como sobre as obrigações relacionadas aos elementos particulares.

\footnotetext{
${ }^{126}$ Convém observar a influência do tempo de duração do contrato em relação à comutatividade. Segundo João Baptista Villela, o tempo tende a desestabilizar a estrutura de comutatividade sob dois aspectos. De um lado, submete as prestações diferidas ao risco de inevitáveis transformações. De outro, a dilação no tempo introduz no pacto a confiança de que a prestação será cumprida. Assim, enquanto o contrato não se extingue pela execução cabal, é possível que sofra alterações, correções, adaptações. (VILLELA, João Baptista. Equilíbrio do contrato, op. cit., p. 93-94).
} 
Nem todos os elementos acidentais, no entanto, desempenham o mesmo papel na economia do contrato. Discriminar sua importância é decisivo para enfrentar com proveito as questões próprias ao inadimplemento recíproco.

Neste sentido, propõe-se que tais elementos sejam divididos conforme a função que exercem no contrato. De acordo com este critério, os elementos particulares do contrato de distribuição podem ser qualificados como de primeiro, segundo e terceiro grau.

Os elementos de primeiro grau são aqueles que possibilitam, diretamente, a consecução do elemento essencial. São, por outras palavras, instrumentos para a realização da própria finalidade do contrato de distribuição. A obrigação de aquisição de cota mínima e a contraposta obrigação de entrega desta cota instrumentalizam e permitem certo controle na colocação dos produtos no mercado. O mesmo vale para a obrigação de manutenção de determinada quantidade de mercadorias em estoque.

Os elementos de segundo grau trazem obrigações autônomas. É o caso das cláusulas de exclusividade. Por meio da exclusividade de comercialização, surge para o distribuidor o dever de não concorrência, uma vez que se encontra obrigado a vender tãosomente os produtos contratuais. A exclusividade de zona, por sua vez, veda que o fornecedor estabeleça outrem na área em que já atua o distribuidor. Os deveres de prestar serviços pós-venda e de participar da publicidade dos produtos são ainda outras obrigações confiadas ao distribuidor além daquela principal de revenda.

No terceiro grau, por fim, encontram-se os elementos que promovem a integração e a colaboração entre as partes. Tal caráter torna-se bastante claro quando se tem em mente os elementos particulares visados. Aqui, figuram as cláusulas que sugerem os preços de revenda e aquelas que obrigam o distribuidor a informar sobre o mercado. A integração assume contornos ainda mais intensos quando o distribuidor deve obedecer às orientações sobre a organização de vendas e recebe treinamento de pessoal.

A tabela abaixo se presta a sintetizar a proposta teórica ora endereçada:

\begin{tabular}{|l|l|l|}
\hline \multicolumn{3}{|c|}{ Elementos particulares (acidentais) } \\
\hline \multicolumn{1}{|c|}{$1^{\mathbf{o}}$ grau } & \multicolumn{1}{|c|}{$2^{\circ}$ grau } & \multicolumn{1}{c|}{$3^{\circ}$ grau } \\
\hline a) Aquisição de cota mínima & a) Exclusividade territorial & $\begin{array}{l}\text { a) Orientações sobre } \\
\text { organização de vendas }\end{array}$ \\
\hline $\begin{array}{l}\text { b) Entrega de cota de } \\
\text { aquisição mínima }\end{array}$ & $\begin{array}{l}\text { b) Exclusividade de } \\
\text { comercialização }\end{array}$ & b) Treinamento de pessoal \\
\hline c) Estoque mínimo & $\begin{array}{l}\text { c) Serviço de assistência } \\
\text { técnica }\end{array}$ & c) Sugestão de preço \\
\hline & d) Publicidade dos produtos & $\begin{array}{l}\text { d) Prestação de informações } \\
\text { sobre o mercado }\end{array}$ \\
\hline
\end{tabular}


A orientação teórica também comporta uma representação gráfica. Acredita-se poder recorrer com proveito a círculos concêntricos, modelo especialmente vocacionado para a exposição de uma escala hierárquica que parte de certo núcleo.

No caso específico do contrato de distribuição, no centro dos círculos situa-se o elemento categorial inderrogável do tipo negocial. A compra das mercadorias do fornecedor pelo distribuidor e a posterior destinação dessas à revenda torna-se o núcleo da representação. Nele, também se encontra o uso da marca, único elemento categorial derrogável, exceto se as partes o afastarem no negócio concreto. Logo em seguida, encontram-se os elementos particulares de primeiro, segundo e terceiro grau, respectivamente.

O objetivo da representação gráfica é estabelecer uma gradação finalística dos elementos do contrato de distribuição: mais próximo do núcleo, mais grave afigura-se o inadimplemento.

A hierarquia desenhada a partir dessa gradação finalística pode ser depreendida do resumo gráfico abaixo:

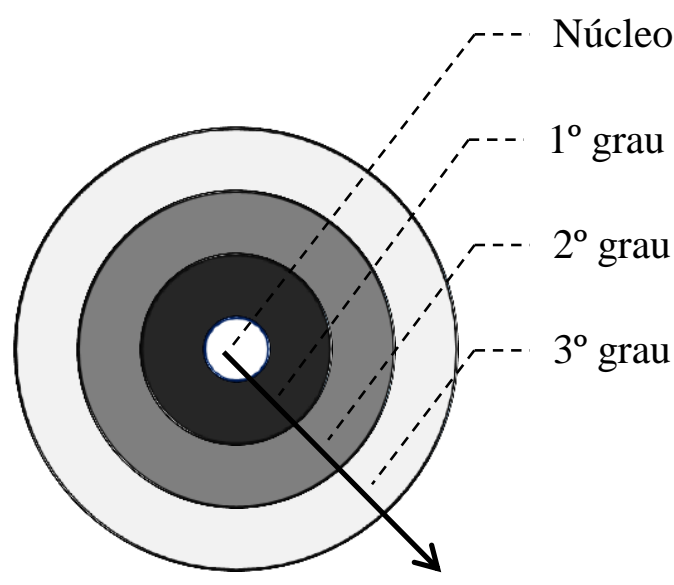

Os elementos do contrato de distribuição foram divididos, desta forma, conforme a função que exercem na economia do negócio. Esta divisão objetiva precisar a relevância da obrigação que a parte deixou de cumprir na economia do contrato. A classificação afigurase de grande importância para o prosseguimento do estudo, uma vez que, frente ao inadimplemento recíproco, torna-se imprescindível medir o comportamento de cada uma delas e, por consequência, o prejuízo causado à economia do negócio.

A consideração dos diversos setores pode levar a divisões distintas. Em contratos que envolvam produtos de alta complexidade, por exemplo, a prestação de serviços de assistência técnica e treinamento de pessoal ganha maior relevância se considerado o papel 
destas prestações na distribuição de bebidas. Isso não afasta, entretanto, a conveniência de se procurar determinar uma estrutura básica que possa servir de parâmetro para a solução dos conflitos.

A gradação finalística dos elementos ora proposta pretende, portanto, fornecer o primeiro parâmetro a ser examinado para se apurar a responsabilidade de cada parte. Somada à forma do incumprimento ${ }^{127}$ (mora, inadimplemento definitivo), sua consideração permitirá que se definam, na segunda parte da pesquisa, as consequências do inadimplemento recíproco.

\section{Conclusões preliminares e caminhos do estudo}

O capítulo dedicou-se especialmente ao plano da existência do contrato de distribuição. Examinar o contrato sob esta perspectiva se mostrou ajustado aos objetivos do trabalho, uma vez que permitiu definir os elementos imprescindíveis à caracterização do tipo negocial.

A identificação dos elementos essenciais, naturais e acidentais do tipo contratual consistiu, de fato, em um dos pontos mais relevantes do capítulo elaborado. Para corroborar os elementos apontados e, assim, concluir a caracterização do contrato de distribuição, este foi submetido à comparação com outros negócios que com ele guardam certa semelhança.

Identificar os elementos do contrato de distribuição não bastou, porém, para endereçar a solução dos problemas enfrentados diante do inadimplemento recíproco. Afinal, o descumprimento pode recair tanto sobre a obrigação principal, como sobre as obrigações relacionadas aos elementos particulares. Estas, por sua vez, podem desempenhar papéis distintos na economia do contrato.

Desta forma, o primeiro capítulo, além de descrever juridicamente o contrato, tem o mérito de proceder a uma nova divisão dos elementos do tipo negocial. Eles são agrupados conforme a função que exercem no contrato de distribuição em elementos de primeiro, segundo e terceiro grau.

Acredita-se que esta gradação finalística dos elementos será de grande utilidade no decorrer da pesquisa. Somada à forma do incumprimento, sua consideração permitirá que se definam, na segunda parte da pesquisa, as consequências do inadimplemento recíproco.

\footnotetext{
${ }^{127} \mathrm{O}$ inadimplemento no contrato de distribuição será tema do capítulo a seguir.
} 
A consideração destes itens, no entanto, de pouco valeria caso o presente capítulo não tivesse empreendido a classificação do contrato de distribuição. A classificação visa a definir o regime jurídico do contrato de distribuição e, assim, o enquadramento do tipo em categorias superiores permite lançar as bases para solucionar os problemas advindos do inadimplemento contratual, especialmente no que se refere às características que emergem de seu enquadramento como um contrato de duração e de colaboração.

Para que tal percepção assente-se em bases firmes, convém examinar mais de perto a disciplina do inadimplemento contratual no Direito brasileiro, em especial a partir do Código Civil e das lições doutrinárias. 


\section{CAPÍTULO 2 - INADIMPLEMENTO RECÍPROCO}

\section{Introdução}

O objeto de investigação deste capítulo é o inadimplemento recíproco ocorrido no âmbito de um contrato de distribuição. Mais precisamente, o capítulo concentra-se no inadimplemento imputável, o qual, conforme aproveita elucidar desde logo, será tratado como sinônimo dos termos incumprimento, descumprimento e não cumprimento.

Importa aclarar ainda que o estudo não procura esgotar o tema do descumprimento obrigacional no direito brasileiro, tampouco caracterizá-lo abstratamente. Realizar-se-á um exame aplicado, ou seja, o não cumprimento ocorrido especialmente no contrato de distribuição.

Conquanto o tema demonstre aparente simplicidade, basta um breve exame dos dispositivos legais e da doutrina para que se revelem suas particularidades. Sua complexidade decorre em grande parte da variedade de situações e de regimes jurídicos que podem surgir quando se diz que um contrato foi inadimplido.

O não cumprimento assume, por exemplo, características próprias conforme a natureza do dever violado; ou conforme a causa do descumprimento. As figuras se distinguem, ainda, conforme a permanência, ao credor, da utilidade da prestação não cumprida. No conceito geral de não cumprimento incluem-se, portanto, várias situações, com efeitos jurídicos diversos.

Diante de tal cenário, tampouco a doutrina apresenta uniformidade no que tange às nomenclaturas, às classificações e aos tratamentos adotados. O embaraço para se conceituar a mora ${ }^{128}$ ou ainda em compreender sua particular abrangência no ordenamento pátrio ${ }^{129}$ e a divergência quanto à conveniência da adoção da violação positiva do contrato no direito brasileiro são apenas alguns dos problemas que ressaltam as dificuldades no trato desta matéria.

\footnotetext{
${ }^{128}$ A propósito Caio Mário da Silva Pereira assevera: "não quisemos oferecer uma definição de mora, pois que todas as tradicionais, formuladas pelos nossos escritores como pelos estrangeiros (Clóvis Beviláqua, Giorgi, Salvat, Demogue etc.), pecam de imperfeição, como salienta Agostinho Alvim, e nas suas águas Serpa Lopes.” (Cf. PEREIRA, Caio Mário da Silva. Instituições de direito civil. Vol. 2, op. cit., p. 293).

${ }^{129}$ A imprecisão em torno da abrangência do conceito de mora adotado pelo ordenamento brasileiro é alvo de crítica feita por Fábio Konder Comparato, segundo o qual "há ainda quem a conceitue, na esteira da tradição romanística, exclusivamente como o retardamento na execução da obrigação, fechando os olhos para a regra, no entanto, claríssima do art. 955 do CC, segundo a qual está também em mora o devedor que não cumpre a prestação na forma ou no lugar convencionados." (Cf. COMPARATO, Fábio Konder. A mora no cumprimento de obrigações contratuais pecuniárias e suas consequências. Revista de Direito Mercantil, Industrial, Econômico e Financeiro, São Paulo, vol. 28, n 74, p. 78-82, 1989. p. 78).
} 
Para oferecer uma resposta satisfatória, o capítulo dedica-se a delinear o conceito de inadimplemento recíproco e definir quais as situações encontram-se abarcadas nesta figura.

Após esclarecer o que se entende por descumprimento recíproco, o trabalho passa a averiguar as modalidades de inadimplemento em que cada contratante pode incorrer durante a vigência do contrato de distribuição. Discute-se, assim, a mora e o inadimplemento definitivo.

Ao lado destas figuras tradicionalmente reconhecidas, parte da doutrina sustenta o cabimento de uma terceira espécie - a violação positiva do contrato. O estudo, a par disso, ocupa-se em verificar a conveniência de sua adoção nos casos de inexecução do contrato de distribuição.

Aclarado o conteúdo, bem como a forma com que ele será tratado, cumpre iniciar as reflexões acerca do inadimplemento recíproco.

\section{Inadimplemento recíproco}

O Código Civil traz um conjunto de normas que define o regramento do inadimplemento singular das obrigações no direito brasileiro. No caso do contrato de distribuição, é exemplo usual deste descumprimento a venda direta do fornecedor em contrato que prevê a atuação exclusiva do distribuidor ${ }^{130}$.

Na prática dos negócios, além do inadimplemento singular, fazem-se corriqueiras as situações em que ambos os contratantes não cumprem devidamente suas obrigações. A solução para estas hipóteses, entretanto, não se encontra prevista no ordenamento. O inadimplemento recíproco, deste modo, põe em xeque a aptidão das disposições legais para resolver situações criadas por arranjos mais sofisticados ${ }^{131}$.

A questão ganha ainda em complexidade quando se está diante do inadimplemento recíproco ocorrido no âmbito de um contrato de distribuição. Isto porque as normas que disciplinam o direito das obrigações constantes do Código Civil, em particular aquelas relativas à inexecução, foram desenhadas em sua grande parte para os contratos de intercâmbio, ou seja, negócios cuja função principal é trocar uma prestação por outra.

\footnotetext{
${ }^{130}$ Conforme TJSP, Ap. Civ. no 18 6.066-4/3-00, 5 a Câm. Dir. Priv., r. Des. Oscarlino Moeller, j. 12.03.2008.

${ }^{131} \mathrm{O}$ problema já é alertado pela doutrina, cf. Forgioni, Paula A. Teoria geral dos contratos empresariais, op. cit., p. 198.
} 
A expressão inadimplemento recíproco é empregada para indicar situações em que ambas as partes deixam de efetuar, nos termos adequados, as prestações a que estão obrigadas. Nestes casos, cada contratante descumpre sua respectiva obrigação, ao não efetuar a prestação que corria por sua própria conta.

Há inadimplemento recíproco, deste modo, quando, no contrato de distribuição, o fornecedor realiza vendas diretas na área de atuação exclusiva do distribuidor, ao passo que o último, não mantém o estoque mínimo exigido contratualmente.

Deve-se notar que as hipóteses abrangidas no inadimplemento recíproco distinguem-se daquelas do concurso de culpas. Estas figuras não se confundem, em que pese a semelhança do descumprimento por ambos os participantes do negócio, pois na culpa concorrente, ambos os contratantes contribuem para o inadimplemento de uma mesma prestação.

Vale recorrer, para facilitar a distinção entre as figuras, a um exemplo. Há culpa concorrente quando o distribuidor, obrigado a cláusula de exclusividade de compra com o fornecedor, adquire dada quantidade de produtos de outro, pois o fornecedor ao qual estava vinculado requereu o imediato adimplemento da obrigação de venda mínima, em detrimento do estipulado no contrato que previa um prazo de 90 dias para o pagamento.

Neste caso, ambos os contratantes, cada um a sua maneira, contribuem para o inadimplemento da cláusula de exclusividade. Tal descumprimento não é inteiramente imputável ao distribuidor tampouco apenas ao fornecedor. A inexecução de dada prestação, por outras palavres, é imputável ao fornecedor e ao distribuidor, cada um com sua respectiva parcela de contribuição para o dano.

Trata-se, em suma, de situação que atinge a imputabilidade do descumprimento e, por conseguinte, o ressarcimento dos danos. Seria, de fato, incongruente que a parte obtivesse o pleno ressarcimento de um dano para cuja ocorrência tenha contribuído, ainda que de maneira diminuta.

No inadimplemento recíproco, por outro lado, o descumprimento também é praticado por ambos os contratantes, entretanto, ocorre a inexecução de prestações diversas que corriam sob a responsabilidade de cada um dos contratantes. Assim, no contrato de distribuição, o fornecedor não realiza uma prestação por ele assumida e o distribuidor também não o faz, em relação à prestação que a ele competia. 
Conceituado, em linhas gerais, o inadimplemento recíproco, faz-se oportuno notar que tal figura abarca duas grandes modalidades. Abrange, primeiramente, as hipóteses de inexecução de prestações correspectivas, ou seja interdependentes, e simultâneas ${ }^{132}$.

A solução para estes casos, via de regra, vale-se do prescrito no art. 476 do Código Civil. Trata-se da exceção do contrato não cumprido, figura que suspende temporariamente a obrigação de adimplir enquanto o outro não executar sua prestação.

Cabe recorrer, como exemplo, ao contrato de locação. Neste contrato, o locatário pode opor tal exceção e, com isso, suspender a execução de sua obrigação de pagar o aluguel, caso o locador ainda não lhe tenha entregue a coisa, cuja posse contratara.

O manejo da exceção do contrato não cumprido pressupõe, assim, que as prestações, além de interdependentes, sejam simultâneas. Isto, no entanto, muito dificilmente ocorrerá no contrato de distribuição, o que torna raro a aplicação da exceção do contrato não cumprido para o inadimplemento de tal negócio, conforme se analisará com maiores minúcias na segunda parte deste trabalho ${ }^{133}$.

Nos contratos em que há multiplicidade de prestações e contraprestações, tal qual o contrato de distribuição, o inadimplemento recíproco, todavia, não se caracteriza apenas em virtude do descumprimento de obrigações interdependentes ${ }^{134}$.

O inadimplemento recíproco resta também configurado quando do descumprimento de quaisquer obrigações emanadas do vínculo, mesmo que umas não sejam a razão de ser das outras. Obrigações desta natureza são características desta modalidade de negócio, cujo escopo é mais o desenvolvimento de certa atividade que a simples troca de prestações.

Para bem ilustrar o objeto de estudo, aproveita recorrer a alguns exemplos. Haverá descumprimento recíproco quando o fornecedor quebra a exclusividade territorial ao passo que o distribuidor não adquire a quantidade mínima exigida de mercadorias. Caracteriza-se ainda no caso de um distribuidor de produtos luxuosos que passa a vendê-los a preços que, de tão baixos, aviltam o bom nome da marca enquanto o fornecedor exige a compra excessiva de peças para estoque.

Importante notar que o inadimplemento de prestações não interdependentes acarreta consequências jurídicas diversas. A exceção do contrato não cumprido não mais se aplica e

\footnotetext{
${ }^{132}$ Cf. MANTUCCI, Daniele. L'inadempimento reciproco. Napoli: Edizioni Scientifiche Italiane, 1990. p. 13.

${ }^{133}$ Cf. item 1.6. do capítulo 1 da Parte II.

${ }^{134}$ Vale observar que, em obra específica sobre o tema, Mantucci defende o emprego da expressão inadimplemento recíproco apenas para as hipóteses que comportem o recurso à exceção do contrato não cumprido. Para os demais casos, o termo por ele empregado é "inadimplemento de todos os contratantes". Trata-se, porém, de mera opção terminológica. Cf. MANTUCCI, Daniele. L'inadempimento reciproco, op. cit., p. 13.
} 
verifica-se situação semelhante a duas inexecuções unilaterais. Deve-se, assim, caracterizar cada descumprimento de maneira autônoma, ou seja, deve-se definir qual a modalidade do inadimplemento do fornecedor e também do distribuidor.

A exata compreensão desta figura requer, portanto, a análise das modalidades do inadimplemento obrigacional. Antes porém, afigura-se conveniente traçar um panorama acerca do inadimplemento obrigacional no direito brasileiro hodierno, em especial a partir da disciplina do Código Civil. Pretende-se, com tal exame, obter as noções propedêuticas que autorizarão proceder, em seguida, a uma investigação mais aprofundada das modalidades de inadimplemento que os contratantes podem incorrer no curso da relação obrigacional.

\section{Aspectos gerais do inadimplemento das obrigações}

Numa sociedade de Direito Privado, o Estado não fixa uma determinada maneira de agir. Os cidadãos têm liberdade para escolher e disciplinar os próprios interesses e, por isso, podem contratar ${ }^{135}$. O contrato é um instrumento privilegiado da autonomia privada e, por meio dele, as partes podem criar, modificar ou extinguir relações jurídicas obrigacionais.

As obrigações assumidas, por seu turno, devem ser fielmente executadas. Consoante tal cânone, o ordenamento reconhece o direito do credor de exigir a integral observância do pactuado, a fim de que o cumprimento se dê na forma, lugar e tempo previstos. O credor, inclusive, não é obrigado a aceitar prestação diversa da devida, ainda que mais valiosa, conforme o art. 313 do Código Civil. O adimplemento é, pois, o fim último da obrigação ${ }^{136}$.

O cumprimento dos deveres emanados do vínculo, por conseguinte, coloca fim à relação obrigacional ${ }^{137}$. O adimplemento é, portanto, o modo natural de extinção da relação obrigacional.

O não cumprimento das obrigações, entretanto, pode ocorrer pelas mais variadas circunstâncias. A inexecução dos preceitos contratuais figura, consequentemente, como a

\footnotetext{
${ }^{135}$ Cf. CANARIS, Claus-Wilhelm. A liberdade e a justiça contratual na 'sociedade de direito privado', in António Pinto Monteiro (coord.). Contratos: actualidade e evolução. Porto. Universidade Católica, 1997, p. 51.

${ }^{136}$ Nas palavras de Couto e Silva "o adimplemento atrai e polariza a obrigação. É o seu fim". (COUTO E SILVA, Clóvis V. do. A obrigação como processo, op. cit., p. 17).

${ }^{137}$ Não obstante tratamento detalhado a ser empreendido no item 4.1.3 deste capítulo, cumpre, desde logo, anotar que a relação jurídica obrigacional não se reduz ao dever de prestar. Ela comporta ainda deveres secundários e laterais e, portanto, somente o cumprimento de todos estes deveres coloca fim à relação obrigacional.
} 
exceção. Para empregar uma imagem cara aos juristas, o inadimplemento é da patologia do negócio ${ }^{138}$.

O inadimplemento das obrigações vem disciplinado no título IV, do livro I, da Parte Especial do Código Civil. Observados os dispositivos legais, depreende-se que o legislador pátrio optou por não conceituar o que se compreende por inadimplemento. Em linha com o Código Civil de 1916, preferiu disciplinar, em grande medida, as consequências do não cumprimento. Assim, da leitura do art. 389, constata-se o "efeito geral e típico ${ }^{139 "}$ do inadimplemento das obrigações, qual seja, o nascimento para o devedor do dever de reparar os prejuízos ocasionados por seu descumprimento ao credor.

Pode-se afirmar, de maneira bastante incipiente, que se verifica o inadimplemento de uma obrigação sempre que a respectiva prestação deixe de ser efetuada nos termos $\operatorname{adequados}^{140}$.

Este conceito, todavia, não basta para precisar o inadimplemento. Nele, estão abrangidos, por exemplo, tanto acontecimentos que provocam a extinção do vínculo obrigacional quanto àqueles que possibilitam a realização coativa da prestação ${ }^{141}$. Trata-se, portanto, de noção excessivamente ampla, por comportar várias situações com regimes jurídicos diversos.

Na busca por uma melhor definição, a doutrina costuma analisar qual a causa do descumprimento. Procura ainda distinguir as várias modalidades abrangidas nesse conceito amplo, mediante o exame do resultado criado pelo descumprimento na relação jurídica obrigacional $^{142}$.

Cumpre observar que estes dois critérios se inter-relacionam e é, justamente, através da combinação de ambos que se define a espécie do inadimplemento e, isto posto, o regime jurídico aplicável em cada caso.

\footnotetext{
${ }^{138}$ Cf. ALviM, Agostinho. Da inexecução das obrigações e suas consequências. $5^{\text {a }}$ ed. São Paulo: Saraiva, 1980. p. 3 e 6.

${ }^{139}$ A expressão "efeito geral e típico" é utilizada por Martins-Costa em seus comentários ao Código Civil (Martins-Costa, Judith. Comentários ao novo Código Civil. Vol. V, tomo II: do inadimplemento das obrigações. Coord. Sálvio de Figueiredo Teixeira. Rio de Janeiro: Forense, 2009).

${ }^{140}$ Cf. CosTA, Mário Júlio de Almeida. Direito das obrigações. 12a ed. rev. e at.. Coimbra: Almedina, 2009. p. 1033.

${ }^{141}$ Conforme se elucidará a seguir, há inadimplemento definitivo na primeira situação; e mora, nas outras.

${ }^{142}$ Para a divisão das modalidades de inadimplemento conforme causa e efeito Cf. CosTA, Mário Júlio de Almeida. Direito das obrigações, op. cit., p. 1034; VARELA, João de Matos Antunes. Das obrigações em geral. Vol II. $3^{\text {a }}$ reimp. da $7^{\text {a }}$ ed. Coimbra: Almedina, 1997. p. 62-64; Assis, Araken de. Resolução do contrato por inadimplemento. $4^{a}$ ed. rev. e atual. São Paulo: Editora Revista dos Tribunais, 2004. p. 100-102. Assis, Araken de. Comentários ao Código Civil brasileiro. Vol. V: do direito das obrigações. Coord. Arruda Alvim e Thereza Alvim. Rio de Janeiro: Forense, 2007. p. 629- 631; e AGUIAR JúNIOR, Ruy Rosado de. Comentários ao novo Código Civil. Vol. VI, tomo II: da extinção do contrato. Coord. Sálvio de Figueiredo Teixeira. Rio de Janeiro: Forense, 2011. p. 535-536.
} 
Quando se analisa a causa do não cumprimento, importa distinguir se a prestação deixou de ser realizada em consequência da ação (ou omissão) do obrigado ou se derivou de fato a ele não imputável. Examina-se, deste modo, a presença ou não de nexo de imputação entre a conduta do devedor e o evento danoso. O descumprimento dir-se-á, então, imputável ou não imputável ${ }^{143}$.

Esta classificação presta-se, essencialmente, a destacar o inadimplemento propriamente dito da impossibilidade superveniente. A despeito de ambas as situações conduzirem a insatisfação dos interesses do credor em razão da não realização da prestação, estas figuras não devem ser confundidas.

Para compreender a estrutura normativa que discrimina tais situações, convém recorrer a alguns dispositivos do Código Civil. São eles os arts. 234, 248 e 250, os quais versam sobre as modalidades das obrigações, e ainda ao art. 396, cujo texto estabelece, $a$ contrario sensu, que o devedor somente incorre em mora caso exista fato ou omissão a ele imputável.

Da leitura destes dispositivos, nota-se que a imputabilidade é o "eixo central da teoria do inadimplemento ${ }^{144 "}$ ". Logo, pode-se afirmar que "somente no incumprimento imputável há um autêntico inadimplemento ${ }^{145 \%}$. Por sua vez, quando a obrigação não é cumprida em razão de fato não imputável ao devedor, há impossibilidade superveniente.

Há descumprimento contratual, deste modo, quando a prestação, mesmo possível, não é realizada pelo obrigado. Há também inadimplemento quando, no momento da execução, a prestação tornou-se impossível por ato imputável ao devedor. Não basta, assim, a ausência de cumprimento, nem a consequente insatisfação dos interesses do credor para que seja configurado o inadimplemento propriamente dito.

Não há, todavia, inadimplemento quando, no momento da execução, a prestação ou a realização dela não é possível, seja em razão de ato de sua contraparte, de terceiro, ou de caso fortuito ou força maior. Trata-se de impossibilidade superveniente o que, em rigor, é hipótese bastante diversa do inadimplemento.

Basta pensar, por exemplo, em incêndio que destrói as mercadorias que estavam guardadas em depósito e impossibilita a entrega pelo fornecedor ao distribuidor no termo

\footnotetext{
${ }^{143}$ No presente trabalho, culpa e imputabilidade não são tomadas como sinônimos, em linha com MartinsCosta. Cumpre anotar, entretanto, que há na doutrina intensa discussão em torno dos conceitos de imputabilidade e culpa. Os doutrinadores dividem-se, segundo Martins-Costa, em dois grandes grupos. Perfilam-se, de um lado, aqueles que consideram que a imputabilidade é sempre culposa. Noutro, reúnem-se os partidários da não coincidência entre os conceitos. Para um exame mais aprofundado da divergência, cf. MARTINS-Costa, Judith. Comentários ao novo Código, op. cit., p. 130-137.

${ }_{144}$ Cf. Martins-Costa, Judith. Comentários ao novo Código Civil, op. cit., p. 372.

${ }^{145}$ Cf. Costa, Mário Júlio de Almeida. Direito das obrigações, op. cit., p. 1034.
} 
fixado. Ou no distribuidor que se recusa a receber a mercadoria e impossibilita que o fornecedor cumpra sua prestação. No contrato de distribuição, a impossibilidade no cumprimento da obrigação de publicidade resta ainda presente quando uma emissora, contratada para divulgação da marca, suspende arbitrariamente o serviço.

Nestes casos, o cumprimento deixa de ser devido diante da impossibilidade de prestar e a pretensão à prestação é excluída. Mais precisamente, na impossibilidade superveniente, a prestação deixa de ser devida; ao passo que o inadimplemento pode ser conceituado como a não realização da prestação devida, enquanto devida ${ }^{146}$.

A distinção entre impossibilidade superveniente e inadimplemento afigura-se particularmente útil quando são consideradas suas consequências. Conquanto ambas as figuras possam conduzir a extinção da relação jurídica obrigacional, somente a segunda faz nascer o dever de reparação previsto no art. 389 do Código Civil.

O nascimento do dever de reparação depende da existência de nexo de imputação entre o evento danoso e a conduta do devedor, conforme entendimento consagrado no art. 395 do diploma pátrio. A doutrina assevera, em razão disso, que imputar significa atribuir responsabilidade $^{147}$. A responsabilidade indenizatória, assim, estará presente somente no inadimplemento imputável.

A impossibilidade superveniente por ato não imputável ao devedor, por sua vez, afasta o nexo de imputação e, consequentemente, a responsabilização. É o que determina o art. 393 do Código Civil pátrio para as hipóteses de caso fortuito e força maior ${ }^{148}$.

A classificação quanto à causa analisa, portanto, se o não cumprimento ocorreu em decorrência de fato imputável ou não imputável ao obrigado e presta-se, essencialmente, a distinguir o inadimplemento propriamente dito - verdadeiro alvo de investigação do presente trabalho - da impossibilidade superveniente.

Este critério, todavia, não é suficiente para discriminar todas as modalidades abrangidas no conceito de inadimplemento. Para traçar um panorama preciso, faz-se necessário ir além do nexo de imputação.

\footnotetext{
${ }^{146}$ Cf. MARTins-Costa, Judith. Comentários ao novo Código, op. cit., p. 129.

${ }^{147}$ Cf. Martins-Costa, Judith. Comentários ao novo Código, op. cit., p. 135.

${ }^{148} \mathrm{O}$ art. 1218 do Código Civil italiano de maneira ainda mais clara estatui que o devedor libera-se do dever de indenizar somente se provar que o não cumprimento ou o atraso decorrem de fato a ele não imputável. A estreita ligação entre imputação e responsabilidade é evidenciada também pelo $\S 280$ do BGB, cujo texto estabelece que o credor não poderá exigir indenização do devedor quando a violação de um dever da relação obrigacional não for imputável a este último.
} 
Nesta esteira, a doutrina costuma distinguir as modalidades de inadimplemento, conforme o efeito ou o resultado produzido na relação jurídica obrigacional. $\mathrm{O}$ inadimplemento divide-se, assim, em definitivo e não definitivo.

No inadimplemento não definitivo, mais conhecido como mora, a prestação não foi efetuada no tempo, lugar ou modo pactuado, conforme dispõe o art. 394 do Código Civil. A prestação, no entanto, ainda é possível e útil ao credor.

A mora pressupõe, à vista disso, a possibilidade de que a prestação ainda possa ser cumprida. Em outras palavras, a inexecução é passível de emenda ou, na linguagem do art. 401 do Código, de purgação e, por isso, o inadimplemento não é definitivo.

Há, por exemplo, mora quando uma famosa marca de roupas esportivas não entrega, na data pactuada, as mercadorias destinadas à revenda em território nacional por seu distribuidor exclusivo.

Nem sempre, entretanto, o descumprimento comporta emenda. Quando não mais subsiste para o credor a possibilidade de receber a prestação, há inadimplemento definitivo $^{149}$. O descumprimento torna-se irremediável seja em virtude de impossibilidade superveniente imputável ao devedor, seja devido à perda da utilidade da prestação ao credor.

Haverá, assim, inadimplemento definitivo quando o atraso na entrega das mencionadas mercadorias esportivas torná-las inútil, tendo em vista que se destinavam exclusivamente ao período da Copa do Mundo e a entrega se deu após o término de tal evento.

Ao lado destas figuras tradicionalmente reconhecidas, a doutrina vem sustentando o cabimento de uma terceira via de descumprimento no direito brasileiro: a violação positiva do contrato ${ }^{150}$. As modalidades resumem-se, deste modo, em mora (ou inadimplemento relativo), inadimplemento definitivo (ou absoluto) e, por fim, violação positiva do contrato.

Postas estas noções gerais sobre um dos mais intrincados temas do direito das obrigações, pode-se, a seguir, tratar de cada modalidade do inadimplemento e suas particularidades em face do contrato de distribuição.

\footnotetext{
${ }^{149}$ Trata-se de lição tradicional entre nós, cf. AlviM, Agostinho. Da inexecução das obrigações e suas consequências, $5^{\mathrm{a}}$ ed., São Paulo, Saraiva, 1980. p. 44- 45.

${ }^{150}$ Sobre a admissão da violação positiva no direito brasileiro, merece destaque: SILVA, Jorge Cesa Ferreira da. A boa-fé e a violação positiva do contrato. Rio de Janeiro: Renovar, 2002; e STEINER, Renata Carlos. Complexidade intra-obrigacional e descumprimento da obrigação: da violação positiva do contrato. Dissertação (Mestrado em Direito) - Faculdade de Direito, Universidade Federal do Paraná, Curitiba, 2009.
} 


\section{Mora}

A mora, como visto, é um dos efeitos do descumprimento obrigacional. Ela contrapõe-se ao inadimplemento definitivo, pois pressupõe a possibilidade de que a prestação ainda possa ser cumprida.

O estudo da mora, como acentua a doutrina ${ }^{151}$, afigura-se como um dos mais complexos temas do direito das obrigações. Com efeito, até mesmo a origem da palavra é controvertida.

Segundo Pontes de Miranda, mora advém de memor que significa lembrar, recordar $^{152}$. Para outros, no entanto, o termo prende-se ao aspecto temporal, ou seja, é o retardamento no cumprimento da obrigação ${ }^{153}$.

Cumpre anotar que, tomada neste último sentido, a compreensão técnica aproximase notadamente da percepção corriqueira do termo, para a qual é sinônimo de tardança, delonga ou atraso.

Esta noção é adotada no Código Civil de vários países de tradição romanogermânica, tais como Alemanha ${ }^{154}$, Portugal, Itália ${ }^{155156}$, França ${ }^{157}$, Espanha ${ }^{158}$, Argentina $^{159}$ e Chile $^{160}$. Por sua clareza, aproveita transcrever o art. 804, $\mathrm{n}^{\circ} 2$ do Código Civil português: “o devedor considera-se constituído em mora quando, por causa que lhe seja imputável, a prestação, ainda possível, não foi efetuada no tempo devido".

A compreensão da mora como simples atraso também obteve acolhida em terras pátrias.

\footnotetext{
${ }^{151}$ Cf. AlviM, Agostinho. Da inexecução das obrigações, op. cit., p.10. No mesmo sentido já enunciava Carvalho de Mendonça: "Não é simples, como parece, a determinação exata do conceito de mora". (Cf. Carvalho de MendonçA, José Xavier. Tratado de Direito Comercial Brasileiro. Vol. VI, $1^{\text {a }}$ Parte, op. cit., p. 338).

${ }^{152}$ Cf. PONTES DE MIRANDA, Francisco Cavalcanti. Tratado de direito privado. T. XXIII. $3^{\mathrm{a}}$ ed., $2^{\mathrm{a}}$ reimp. São Paulo: Revista dos Tribunais, 1984. p. 115.

${ }^{153}$ Cf. Gomes, Orlando. Obrigações. Atual. TheOdoro JúnIOR, Humberto. 12a ed. $2^{\mathrm{a}}$ tiragem. Rio de Janeiro: Forense, 1999. p. 167.

${ }^{154}$ Cf. § 286 do Código Civil alemão.

${ }^{155}$ Cf. Art. 1.218 do Código Civil italiano.

${ }^{156}$ Vale transcrever trecho da doutrina que corrobora este entendimento: "la mora è il retardo imputable al debitore." (Cf. BiAnCA, C. Massimo. Diritto civile: la responsabilità. Vol. 5. Milano: Giuffrè, 1994. p. 82).

${ }^{157}$ Cf. Arts. 1.146 e 1.147 do Código Civil francês.

${ }^{158}$ Cf. Art. 1.100 do Código Civil da Espanha.

${ }^{159}$ Cf. Arts. 508 e 509 do Código Civil argentino.

${ }^{160}$ Cf. Art. 1.551 do Código Civil do Chile.
} 
O legislador, lastreado nas Ordenações Filipinas ${ }^{161}$, consagrou tal entendimento no Código Comercial de 1850, nos termos de seus arts. 202 e 204.

Esta orientação prevalecera ainda nas várias iniciativas que antecederam a promulgação do Código Civil de 1916, como se nota da leitura do Esboço de Código Civil de Teixeira de Freitas ${ }^{162}$ e também dos projetos subsequentes, elaborados, respectivamente, por Felício dos Santos ${ }^{163}$, Coelho Rodrigues ${ }^{164}$ e Clovis Bevilaqua ${ }^{165}$.

O Código Civil, como sabido, veio somente em 1916, baseado no projeto daquele último. No decorrer do trâmite legislativo, o dispositivo passou, todavia, por alterações que culminaram na ampliação da noção de mora. O instituto, ao final, fora assim conceituado: “Art. 955. Considera-se em mora o devedor que não efetuar o pagamento, e o credor que não quiser receber no tempo, lugar e forma convencionados" (destaque nosso).

O diploma legal modificou substancialmente o perfil da mora no direito brasileiro. Houve uma ampliação da figura de modo a abranger não apenas o atraso, como também o cumprimento defeituoso em relação ao lugar e ao modo convencionados ${ }^{166}$. Não é exagero dizer que a mora assumiu, a partir deste momento, contornos próprios que distinguem o modelo brasileiro do encontrado na maioria dos países de tradição romano-germânica ${ }^{167}$.

Este conceito foi conservado nas tentativas posteriores de reforma que culminaram na aprovação, em 2002, de um novo Código Civil, baseado no Projeto de $1975^{168}$. No que diz respeito à mora, o novo estatuto acrescentou a expressão "que a lei" ao texto do antigo art. 955. Seu art. 394 assim dispõe: “Considera-se em mora o devedor que não efetuar o

\footnotetext{
${ }^{161}$ As anotações de Coelho da Rocha a dado texto das Ordenações Filipinas dão notícia de que a mora era tomada como o retardamento no cumprimento das obrigações. A norma que deu azo ao comentário dispunha: "E esta cousa assi emprestada deve tornar o devedor ao tempo e prazo, que lhe for posto, e não sendo declarado tempo, cada vez que o acredor lha pedir, e desse tempo fica constituído em mora". (Cf. Código Filipino ou Ordenações e Leis do Reino de Portugal, Livro IV, Título L, 1 [edição fac-símile da $14^{a}$ edição, de 1870, com introdução e comentários de Cândido Mendes de Almeida], Brasília, Senado Federal, 2004. p. 842-843.

${ }^{162}$ Cf. Art. 1.070 do Esboço do Código Civil.

${ }^{163}$ Cf. Art. 375 do Projeto do Código Civil de autoria de Felício dos Santos.

${ }^{164}$ Cf. Art. 414 do Projeto do Código Civil Brasileiro de autoria de Coelho Rodrigues.

${ }^{165}$ Cf. Art. 1.100 do Projeto do Código Civil Brasileiro de Clovis Bevilaqua.

${ }^{166}$ Sobre o conceito de mora em face do direito pátrio, vale frisar a passagem bastante elucidativa de Agostinho Alvim: "é certo que a mora, via de regra, manifesta-se por um retardamento, embora em face do nosso Código, e rigorosamente falando, ela seja antes a imperfeição no cumprimento da obrigação ("tempo", "lugar" e "forma")". (Cf. AlviM, Agostinho. Da inexecução das obrigações, op. cit., p.11).

${ }^{167}$ Cumpre anotar que esta opção não é isenta de críticas como demonstra a reflexão de Orlando Gomes: "Trata-se de conceito que se prende à ideia de tempo. (...). Entretanto, pretende-se que também ocorre quando o devedor não paga no lugar devido ou pela forma convencionada. Essa extensão conceitual foi acolhida na lei pátria. $\mathrm{O}$ legislador não merece aplauso pelo abandono do conceito tradicional. $\mathrm{O}$ próprio nome atesta que se refere a retardamento. Mora é demora, atraso, impontualidade, violação do dever de cumprir a obrigação no tempo devido". (Cf. GOMES, Orlando. Obrigações, op. cit., p. 168).

${ }^{168}$ Cf. o art. 281 do Anteprojeto de Código de Obrigações de 1941, o art. 188 do Anteprojeto de Código de Obrigações de 1963, o art. 179 do Projeto de Código de Obrigações de 1965 e o art. 392 do Projeto de Código Civil de 1975.
} 
pagamento e o credor que não quiser recebê-lo no tempo, lugar e forma que a lei ou a convenção estabelecer".

Este dispositivo comporta uma noção meramente descritiva da mora, a qual não basta para conceituá-la. A determinação da figura requer ainda que a causa do descumprimento seja imputável ao obrigado, seja ele o credor ou o devedor ${ }^{169}$. Neste sentido, preceitua o art. 396: "não havendo fato ou omissão imputável ao devedor, não incorre este em mora".

Incorre em mora, portanto, o devedor que, por causa a ele imputável, não cumpre a prestação no tempo, ou não a realiza no lugar, ou ainda não a efetua pelo modo devidos. Igualmente, haverá mora, se o credor, por causa a ele imputável, se recusa a receber a prestação no tempo, lugar ou forma prescrita na lei ou convencionada pelas partes.

Muito embora a prestação não tenha sido executada, imprescindível destacar que na mora subsiste a possibilidade futura de cumprimento. Assim, a prestação não realizada ainda o pode ser, por continuar a corresponder ao interesse do credor. Não é por acaso, portanto, que o capítulo destinado a discipliná-la termina justamente com as regras atinentes à purgação da mora, nos termos do art. 401 do Código Civil.

Seria o caso, por exemplo, de fornecedor de computadores que entregou as mercadorias desacompanhadas dos respectivos manuais. Apesar do atraso, o descumprimento é perfeitamente passível de emenda, o que se dará com o envio dos manuais faltantes.

Tendo identificado as características essenciais bem como as peculiaridades apresentadas pela mora no ordenamento pátrio, convém examinar, de agora em diante, suas espécies à luz de sua ocorrência em um contrato de distribuição.

\subsection{Espécies de mora}

O art. 394 do Código Civil, de maneira conectada ao adimplemento, assinala três critérios para a configuração da mora, os quais serão examinados, a partir de agora, tendo em vista o contrato de distribuição.

Ocupar-se-á, em primeiro lugar, da mora de tempo, espécie mais corriqueira, para, em seguida, analisar os critérios que distinguem a legislação pátria de outros países de

\footnotetext{
${ }^{169}$ A imputabilidade não só figura como requisito ou elemento da mora, mas como eixo central de toda a teoria do inadimplemento, como visto no item anterior. Mais precisamente, somente haverá um autêntico inadimplemento (seja ele mora ou inadimplemento definitivo), se a causa do descumprimento for imputável ao obrigado. Se não imputável, há que se falar, a rigor, em impossibilidade.
} 
tradição romano-germânica, ou seja, lugar e modo. Refletir-se-á, por fim, acerca das eventuais consequências trazidas pelo reconhecimento da relação obrigacional complexa para a mora, especialmente sobre sua incidência nos deveres que compõem a relação obrigacional.

\subsubsection{Retardo}

A primeira espécie de mora a ser tratada é o retardamento imputável ao obrigado no cumprimento da obrigação.

Neste caso, estará em mora o devedor que não cumprir a obrigação no termo pactuado. Caso não haja um termo fixado, será necessária interpelação, judicial ou extrajudicial, para a constituição em mora, nos termos do art. 397, caput e parágrafo único, do Código Civil. Para a configuração da mora, deste modo, é necessário que a prestação seja exigível.

A entrega atrasada de mercadorias pelo fornecedor ao distribuidor bem ilustra esta modalidade de mora. $\mathrm{O}$ atraso no cumprimento da obrigação de publicidade à cargo do distribuidor, ou na realização de treinamento pelo fornecedor em favor do distribuidor e seus empregados, ou, ainda, a delonga em prestar informações sobre o mercado para o fornecedor são outros exemplos de fácil ocorrência.

\subsubsection{Lugar e modo}

A mora no direito pátrio não se restringe ao retardamento no cumprimento da prestação. Conquanto existam opiniões doutrinárias em sentido diverso ${ }^{170}$, o art. 394 do Código Civil, de forma clara, estatui duas outras espécies de mora, quais sejam, lugar e modo.

Se a prestação é realizada no prazo avençado, todavia, fora do lugar ou de modo diverso do devido, o interesse do credor não é plenamente satisfeito e, consequentemente, não se pode falar em cumprimento. O descumprimento não ocorre somente quando não se

\footnotetext{
${ }^{170}$ De acordo com Jorge Cesa Ferreira da Silva, a mora define-se, exclusivamente, como atraso na prestação, como cumpre transcrever: "Apesar dos termos da definição legal, a mora no direito brasileiro continua vinculada exclusivamente ao tempo da prestação. Isso não significa, por certo, que a mora não ocorrerá quando a prestação for efetuada, ou seu recebimento realizado, no lugar ou na forma distinta do pré-fixado. Porém, nesses casos, o que realmente importará será o tempo que terá de ser gasto para a correta realização da prestação, período que envolverá o estado de mora. As hipóteses vinculadas ao lugar e à forma da prestação, assim, somente ensejarão mora na medida em que provocarem atraso no prestar ou no receber a prestação, ou seja, não são elas suficientes, individualmente, para caracterizar a mora." (Cf. SILVA, Jorge Cesa Ferreira da. A boa-fé e a violação, op. cit., p. 145-146). No mesmo sentido, cf. STEINER, Renata Carlos. Complexidade intra-obrigacional, op. cit., p. 123- 129.
} 
cumpre a obrigação, mas também quando ela é cumprida no lugar ou de modo diferente do convencionado. De fato, se a prestação não foi executada no lugar ou no modo devidos, um autêntico cumprimento não há ${ }^{171}$.

Para a exata compressão, vale recorrer novamente ao exemplo do contrato de distribuição de computadores. Caso o fornecedor remeta os manuais dos computadores revendidos à loja equivocada, não há cumprimento da prestação, caracterizando mora de lugar. Igualmente, não há adimplemento da prestação quando estes manuais, a despeito de sua entrega no prazo e no lugar pactuados, são enviados em língua estrangeira, a despeito da existência de manuais escritos na língua pátria, o que caracteriza a mora de modo.

Não há ainda cumprimento quando se presta assistência técnica sem observar os padrões exigidos, quando se presta orientações incorretas sobre as vendas, quando a sugestões de preço é feita em moeda estrangeira ou ainda quando a publicidade é feita em praça equivocada.

Nestas hipóteses, caso o descumprimento seja imputável ao obrigado e subsista a possibilidade do cumprimento, haverá mora do devedor ou do credor. Deste modo, a mora no sistema brasileiro contempla, além do retardo, o cumprimento defeituoso em relação ao lugar e ao modo.

\subsubsection{A mora frente à relação obrigacional complexa}

A mora, em qualquer de suas modalidades (tempo, lugar e modo), é ligada, costumeiramente, a violação dos deveres de prestação, de modo a excluir de sua incidência a violação dos deveres de proteção ${ }^{172}$.

Para compreender esta afirmação e explorar sua adequação frente ao regramento brasileiro, convém discorrer brevemente sobre os deveres existentes na relação obrigacional complexa ${ }^{173}$.

A relação obrigacional abarca uma série de deveres, os quais não se vinculam somente aos deveres de prestação. A superação da concepção de que a obrigação se esgota no dever de prestar, e no correlato dever de exigir a prestação, faz com que, a par destes,

\footnotetext{
171 “A não-satisfação pode provir de ser antes ou depois do tempo fixado, ou fora do lugar que fora indicado, ou em quantidade inferior à que se prometera, ou em qualidade inferior a que se havia de exigir". (Cf. PonTES DE MIRANDA, Francisco Cavalcanti. Tratado de direito privado, t. XXVI,. $3^{\mathrm{a}}$ ed., $2^{\mathrm{a}}$ reimp. São Paulo: Revista dos Tribunais, 1984. p. 15).

${ }_{172}$ Cf. Martins-Costa, Judith. Comentários ao novo Código, op. cit., p. 327.

${ }^{173}$ Para esta síntese, consultei Costa, Mário Júlio de Almeida. Direito das obrigações, op. cit., p. 73 e ss; e MARTINS-COSTA, Judith. A boa-fé no direito privado, op. cit., 437 e ss.
} 
coloquem-se os deveres laterais derivados da boa-fé objetiva. A relação obrigacional complexa, desta maneira, abrange:

a) Deveres de prestação: os deveres de prestação subdividem-se em deveres primários e secundários. Os deveres primários ou principais constituem o núcleo da relação obrigacional e, por isso, são responsáveis por definir o tipo contratual.

Os deveres secundários ou acidentais, novamente, repartem-se. Existem os deveres secundários meramente acessórios da prestação principal, que se destinam a auxiliar no cumprimento perfeito da prestação principal; e também os deveres secundários com prestação autônoma.

A prestação autônoma, por seu turno, pode figurar como sucedâneo da prestação principal, como a indenização resultante do inadimplemento definitivo que substitui a prestação principal; ou ainda como uma prestação que coexiste com a prestação principal, tal qual a indenização emergente da mora.

b) Deveres laterais (Nebenpflichten): denominados ainda como deveres acessórios de conduta, deveres de conduta, deveres de proteção ou deveres de tutela, decorrem da boa-fé e surgem ao lado dos deveres de prestação.

Estes deveres não visam ao adimplemento da prestação, nem funcionalizam a prestação principal. Prestam-se ao regramento da conduta devida pelas partes ou, por outras palavras, “à exacta satisfação dos interesses globais envolvidos na relação obrigacional complexa ${ }^{174 \%}$. Colocam-se entre eles, de maneira ilustrativa, os deveres de informação, os deveres de notificação e os deveres de cuidado relativos à pessoa e ao patrimônio da contraparte.

A breve síntese aqui apresentada pode ser depreendida através do resumo gráfico abaixo:

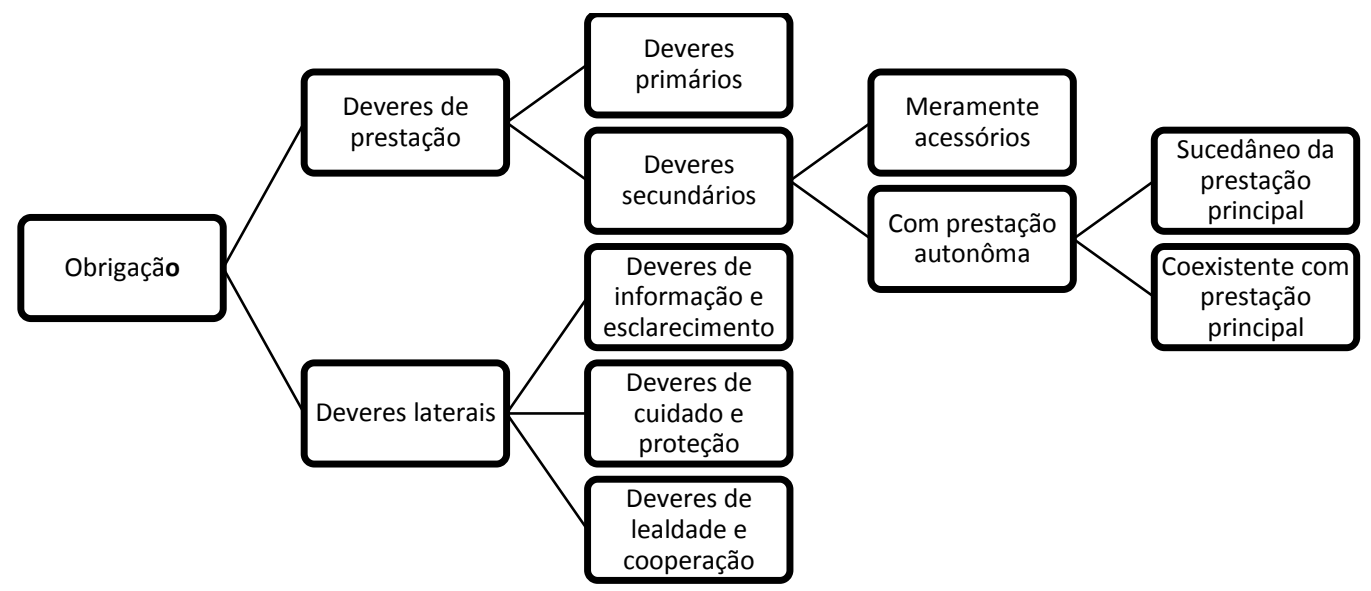

${ }^{174}$ Cf. CostA, Mário Júlio de Almeida. Direito das obrigações, op. cit., p. 77. 
Elaborada uma explicação propedêutica dos deveres presentes na relação obrigacional, cumpre investigar como esta classificação se apresenta no contrato de distribuição. Para tanto, será de grande valia a gradação dos elementos realizada no primeiro capítulo do presente trabalho.

Os deveres secundários meramente acessórios coincidem com aqueles definidos como elementos de segundo grau e, deste modo, abrangem a aquisição de cota mínima, a entrega de cota mínima, a manutenção de estoque mínimo e o uso da marca.

Os deveres secundários com prestação autônoma coincidem com os elementos de segundo grau. São eles: exclusividade territorial, exclusividade de comercialização, serviço de assistência técnica e publicidade dos produtos.

No que diz respeito aos deveres anexos, necessário notar que o enquadramento do contrato de distribuição como um contrato de colaboração produz efeitos imediatos sobre eles.

Nesta categoria negocial, os deveres comumente caracterizados como laterais são, geralmente, colocados para dentro do contrato por meio de estipulações das partes e tornam-se deveres de prestação. É o caso, por exemplo, do dever de informar. Na maioria dos contratos não classificados como de colaboração, o dever de informar decorre da boafé. No contrato de distribuição, por sua vez, o dever de informar está intrinsecamente relacionado à economia do negócio.

Estes deveres foram definidos como elementos de terceiro grau e abrigam as obrigações de prestar orientações sobre organização de vendas, treinamento de pessoal, sugestão de preço e prestação de informações sobre o mercado.

O reconhecimento da relação obrigacional complexa produz efeitos sobre a concepção de adimplemento, posto que não basta a satisfação do dever primário. Faz-se necessário o cumprimento de todos os deveres emanados do vínculo.

Tal entendimento produz, igualmente, consequências para o inadimplemento, o qual pode recair sobre deveres de qualquer natureza. $\mathrm{O}$ enquadramento da violação de cada espécie de dever frente às modalidades de inadimplemento suscita acesa discussão na doutrina pátria.

De acordo com parcela significativa, a violação dos deveres de prestação configura mora. Segundo esta mesma linha de raciocínio, a inobservância dos deveres de proteção 
restaria por caracterizar a violação positiva do contrato ${ }^{175}$, figura advinda do direito germânico.

Outros, por sua vez, entendem que não se faz necessário o recurso a uma terceira espécie de descumprimento para abranger os deveres laterais, os quais podem se submeter, a depender da análise acerca da utilidade da prestação, a dois caminhos: mora ou inadimplemento definitivo ${ }^{176}$.

O presente trabalho, pelas razões que serão expostas detidamente no item 5 dedicado a violação positiva do contrato, filia-se ao último entendimento. Antes de iniciar tal tema, faz-se necessário, porém, concluir o estudo da mora através do exame de suas consequências.

\subsection{Consequência da mora}

As consequências do descumprimento contratual no contrato de distribuição serão investigadas na Parte II do presente trabalho. Por ora, basta enumerar os possíveis efeitos da mora, de modo a obter um tratamento concatenado e claro do tema, deixando para o momento oportuno um exame mais detalhado do tema.

Um de seus principais efeitos está previsto no art. 395 do Código Civil, o qual estabelece que o devedor em mora responde pelos prejuízos que dela se originarem. $\mathrm{O}$ contratante fiel, deste modo, é reparado dos prejuízos que sofreu por não ter recebido a prestação no tempo, no lugar ou na forma devida.

Como sabido, na mora subsiste a possibilidade de cumprimento ulterior da prestação, pois ainda afigura-se útil ao credor. Em vista disso, além das perdas e danos, ao credor é dado exigir a realização coativa da prestação. No entanto, caso findar o interesse do credor, cessa a possibilidade de purgação da mora, a qual se converte em inadimplemento definitivo, nos termos do parágrafo único do art. 395 do Código Civil.

Outra consequência encontra-se prevista no art. 399 do Código Civil e diz respeito a impossibilidade superveniente da prestação. $O$ devedor em mora responde pela

\footnotetext{
${ }^{175}$ Este posicionamento é adotado por Jorge Cesa da Silva Ferreira, cuja passagem aproveita transcrever: "a mora deve ser vinculada somente aos atos de cumprimento dos deveres que afetem diretamente os interesses de prestação, e não a todos os deveres envolvidos na relação (SILVA, Jorge Cesa Ferreira da. A boa-fé e a violação, op. cit., p. 162). Cf. ainda MARTINS-CosTA, Judith. Comentários ao novo Código, op. cit., p. 327; e STEINER, Renata Carlos. Complexidade intra-obrigacional, op. cit., p. 194.

${ }^{176}$ Este entendimento é corroborado por GAZALLE, Gustavo Kratz. O conceito de mora, op. cit.,72. Em linha, NANNI, Giovanni Ettore. Mora. In LotUfo, Renan; NANNI, Giovanni Ettore (coord). Obrigaçães. São Paulo: Atlas, 2011. p. 583-589.
} 
impossibilidade da prestação, ainda que esta resulte de caso fortuito ou de força maior, salvo se provar que o dano adviria mesmo se a prestação fosse cumprida regularmente ${ }^{177}$.

É caso, por exemplo, de fornecedor que não entrega as mercadorias na data fixada e, durante sua mora, estas são destruídas por vendaval que atinge a região de seu depósito. Nesta hipótese, o devedor responde pelas consequências da força maior, a menos que prove que as mercadorias teriam igualmente perecido se tivessem sido tempestivamente entregues.

Aproveita anotar, por fim, um último efeito que diz respeito apenas à mora do credor e relaciona-se a atenuação da responsabilidade do devedor pela conservação da coisa. Nos termos do art. 400, diante da mora do credor, o devedor passa a responder apenas pelos danos provenientes de seu dolo.

Não responderá, assim, o fornecedor caso o material guardado em depósito pereça em virtude da falta de negligência de seus empregados, se, anteriormente, o distribuidor recusou-se a receber dadas mercadorias no tempo, lugar e modo pactuados.

\section{Violação positiva do contrato}

Como visto, ao lado das figuras tradicionalmente reconhecidas, quais sejam a mora e o inadimplemento definitivo, a doutrina vem sustentando o cabimento de uma terceira via de descumprimento no direito brasileiro: a violação positiva do contrato ou, como preferem alguns, violação positiva do crédito $^{178}$.

Neste cenário, cumpre analisar a conveniência de sua adoção no direito brasileiro e, sobretudo, a utilidade de se recorrer a esta figura para as hipóteses de descumprimento ocorridas no âmbito do contrato de distribuição.

5.1. Origem e âmbito de aplicação

O conceito de violação positiva do contrato foi desenvolvido na Alemanha por Herman Staub no início do século XX, em razão de uma lacuna na disciplina do

\footnotetext{
177 “Tudo que acontece lhe é imputável, devido ao estado de mora que se criou." (Cf. PONTES DE MIRANDA, Francisco Cavalcanti. Tratado de direito privado, t. XXIII, op. cit., p. 181).

${ }^{178}$ Cf. Pontes De MiRANDA, Francisco Cavalcanti. Tratado de direito privado, t. II. $4^{\mathrm{a}}$ ed., São Paulo: Editora Revista dos Tribunais, 1984. p. 243. No direito português, cf. VARELA, Antunes. Das obrigações em geral. Vol II, op. cit., p. 127.
} 
descumprimento obrigacional constante do $\mathrm{BGB}^{179}$.

O diploma legal contemplava, à época, apenas duas espécies de inexecução das obrigações, quais sejam a mora, tomada como retardo no cumprimento, e a impossibilidade da prestação.

O modelo germânico, deste modo, não considerava as hipóteses em que "alguém viola uma obrigação por meio de uma conduta positiva, fazendo o que deveria omitir, ou executando a prestação devida, mas de modo inexato ${ }^{180}$ ". Restavam fora de seu regramento, portanto, as hipóteses de adimplemento pontual, porém defeituoso.

Diante desta lacuna, Staub desenvolveu a noção de violação positiva do contrato, denominação que enfatiza o dano derivado de comportamento ativo do obrigado. A construção foi acolhida pela doutrina e jurisprudência e, por se tratar de espécie residual, ou seja, que reúne as hipóteses não abarcadas pelas anteriores, passou a abranger, a partir do reconhecimento da relação obrigacional complexa, também a infração dos deveres laterais.

A violação positiva do contrato, portanto, é uma espécie residual que abrange o cumprimento defeituoso e a violação dos deveres laterais ${ }^{181}$. Aproveita anotar que a figura encontrou abrigo também no direito português, conforme se conclui pelo art. 799, $\mathrm{n}^{\circ} 1$ do Código Civil ${ }^{182}$.

No que diz respeito aos efeitos, a violação positiva do contrato enseja o ressarcimento dos danos causados pela infração, conforme princípio preconizado desde o

\footnotetext{
179 "Até a reforma do direito das obrigações, o inadimplemento era disciplinado pela lei de maneira imperfeita e incompleta. As regras legais sobre a impossibilidade, sobre a mora do devedor e sobre a garantia contra vícios não cobriam todas as violações de deveres verificadas. Isso era especialmente evidente nos tipos contratuais para os quais a lei não previa qualquer garantia, como, por exemplo, os contratos de prestação de serviço e de trabalho. Entre outras coisas destinadas a por fim a tal lacuna jurídica, a violação positiva do contrato foi desenvolvida e empregada através da aplicação por analogia dos $\S \S 280,286$ ou dos $\S \S 325,326$ do regramento antigo para cuidar de todos os casos em que a violação culposa de deveres nos contratos sinalagmáticos não fosse disciplinada pela lei". (Tradução livre de "Bis zur Schuldrechtreform war die Schlechtleistung im Gesetz nur unzureichend und unvollständig geregelt. Die gesetzlichen Regeln über die Unmöglichkeit, den Schuldnerverzug und die Mängelgewährleistung erfassten nicht jede aufgetretene Pflichtverletzung. Dies zeigte sich insbesondere bei Vertragstypen, die über keine Gewährleistungsregelungen verfügten, wie z.B. beim Dienst- oder Arbeitsvertrag. Unter anderem zur Schließung dieser Regelungslücke wurde für alle nicht geregelten Fälle einer schuldhaften Pflichtverletzung in entsprechender Anwendung der $\S \S 280,286$ a.F. bzw. $\S \S 325,326$ a.F. bei gegenseitigen Verträgen das Rechtsinstitut der positiven Forderungsverletzung (pFV) entwicklelt und angewendet". (Cf. BROX, Hans; WALKER, Wolf-Dietrich. Allgemeines Schuldrecht, 34. aktualisierte Auflage, München: C. H. Beck, 2010. p. 285).

${ }^{180}$ Cf. STAUB, Hermann. Le violazioni positive del contratto (Die positiven Vertragsverletzungen). Trad. Giovanni Varanese. Napoli: Edizioni Scientifiche Italiane, 2011. p. 39.

${ }^{181}$ Cf. STEINER, Renata Carlos. Complexidade intra-obrigacional, op. cit., p. 175.

${ }^{182}$ No Direito português, a violação positiva é tratada como cumprimento defeituoso. Neste caso, trata-se de gênero que compreende a execução defeituosa e a violação dos deveres laterais (Cf. CoSTA, Mário Júlio de Almeida. Direito das obrigações, op. cit, p. 1.058- 1.060).
} 
surgimento da figura ${ }^{183}$. É possível também ensejar o direito de resolução, em razão da gravidade da violação ${ }^{184}$.

Examinada a origem e o âmbito de aplicação da violação positiva do contrato, convém analisar o enquadramento destas hipóteses no direito brasileiro à luz, sobretudo, do conceito amplo de mora, a fim de concluir sobre o proveito da adoção da violação positiva do contrato no Brasil.

\subsection{Aplicação no Brasil}

A conveniência da recepção da violação positiva do contrato no direito brasileiro suscita aceso debate, dividindo-se os doutrinadores em dois grandes grupos. De um lado, encontram-se aqueles partidários da viabilidade e da utilidade da recepção da figura ${ }^{185}$. Outros, por sua vez, entendem desnecessária a adoção de uma terceira via de descumprimento frente ao conceito amplo de mora positivado no Código Civil ${ }^{186}$.

Neste cenário, convém refletir sobre as hipóteses que ensejariam a aplicação da violação positiva do contrato, quais sejam: o mau cumprimento de deveres de prestação e o descumprimento de deveres laterais.

No cumprimento defeituoso ou inexato, figura já tratada no item 4.1.2., a prestação é executada, porém, sua realização ocorre de forma diversa da devida. A subsunção do cumprimento defeituoso à violação positiva do contrato não pode ocorrer à margem do regramento pátrio, especialmente sem a consideração do art. 394 do Código Civil, o qual elenca o modo de cumprimento entre os fatores determinantes da mora.

Diante deste conceito de amplo de mora, o cumprimento defeituoso não se apresenta como uma espécie de quebra positiva do contrato. Ele recairá na mora ou no inadimplemento definitivo, conforme a aferição da utilidade da prestação para o credor.

No que diz respeito ao descumprimento dos deveres laterais, o recurso a uma terceira espécie de inadimplemento permanece questionável. A exata compreensão da

\footnotetext{
${ }^{183}$ Cf. STAUB, Hermann. Le violazioni positive del contratto, op. cit., p. 48.

${ }^{184}$ Cf. Martins-Costa, Judith. Comentários ao novo Código, op. cit., p. 234.

${ }^{185} \mathrm{O}$ cabimento da violação positiva do contrato é defendido por SILVA, Jorge Cesa Ferreira da. A boa-fé e a violação, op. cit., 265-268; STEINER, Renata Carlos. Complexidade intra-obrigacional, op. cit., 186; MARTINS-Costa, Judith. Comentários ao novo Código, p. 226-234.

${ }^{186}$ Este entendimento é sustentado por GAZALle, Gustavo Kratz. O conceito de mora op. cit., p. 81-82; NANNI, Giovanni Ettore. Mora. In LotUfo, Renan; NANNI, Giovanni Ettore (coord). Obrigações. São Paulo: Atlas, 2011. p. 583-589; FrAdERA, Vera Jacob. In GAZALlE, Gustavo Kratz. O conceito de mora, op. cit., p. 12; e TePedino, Gustavo; SCHREIBER, Anderson. Código Civil comentado: direito das obrigações - arts. 233 $a$ 420. Vol. 4. São Paulo: Atlas, 2008. p.343-344.
} 
mora no direito brasileiro aponta por não excluir os deveres laterais, especialmente com o advento do Código Civil de 2002.

O reconhecimento da boa-fé objetiva no art. 422 do Código Civil de 2002, bem como a inclusão do não cumprimento na forma que a lei estabelecer entre as hipóteses de mora, são pontos que merecem consideração ao se analisar a abrangência do conceito da mora.

Segundo tese defendida na doutrina, a modificação empreendida pelo art. 394 do Código Civil com a inserção de tal expressão produziu profunda modificação e possibilitou a inclusão de hipóteses que violam a cláusula geral da boa-fé entre as hipóteses de mora ${ }^{187}$.

O reconhecimento da relação obrigacional complexa e a expressa adoção da boa-fé no Código Civil de 2002 torna difícil conceber, de fato, que tais situações não estariam previstas no art. 394 e mereceriam um tratamento distinto dos demais deveres. A inexecução dos deveres laterais, assim como dos deveres de prestação, pode caracterizar, portanto, mora ou inadimplemento definitivo ${ }^{188}$.

O caráter controverso do recurso a uma terceira espécie de inadimplemento é ressaltado ainda pela igualdade de efeitos jurídicos conferida por ambos os enquadramentos. A violação positiva do contrato pode ensejar indenização ou até mesmo a resolução.

Estas consequências, no entanto, seriam exatamente idênticas caso o cumprimento defeituoso ou a infração dos deveres laterais fossem enquadrados como mora ou inadimplemento definitivo, o que coloca em xeque a necessidade de se importar uma nova figura em detrimento dos institutos consagrados na lei brasileira.

Pelo exposto, depreende-se que o conceito atual de mora abrange não somente a modalidade do atraso no cumprimento da prestação, como também as hipóteses de cumprimento imperfeito e a violação dos deveres laterais derivados da boa-fé ${ }^{189}$, de modo que não se faz necessário o recurso a esta terceira modalidade.

A inexecução das obrigações conforme preconizado no modelo jurídico brasileiro conduz, assim, a apenas dois caminhos: mora ou inadimplemento definitivo. A

\footnotetext{
187، $P$ Portanto, se o conceito de mora prevê expressamente que os deveres contratuais devem ser cumpridos na forma que a lei estabelecer, e, havendo infração ao dispositivo legal que consagra a boa-fé, mora haverá nesses casos." (Cf. GAZAlle, Gustavo Kratz. O conceito de mora no Código Civil de 2002. Porto Alegre: Sergio Antonio Fabris, 2008. p. 78-79).

${ }^{188}$ Este entendimento é corroborado por GAZALLE, Gustavo Kratz. O conceito de mora, op. cit.,72. Em linha, NANNI, Giovanni Ettore. Mora. In Lotufo, Renan; NANNI, Giovanni Ettore (coord). Obrigações. São Paulo: Atlas, 2011. p. 583-589.

${ }^{189}$ Cf. GaZALle, Gustavo Kratz. O conceito de mora, op. cit., p. 18.
} 
caracterização de uma ou outra hipótese, como visto, dependerá da permanência do interesse do credor no cumprimento da obrigação inadimplida.

Além das considerações intrinsecamente relacionadas ao ordenamento brasileiro, ao se investigar a conveniência de se importar tal figura, convém considerar o destino tomado pelo instituto em seu país de origem, especialmente após a reforma empreendida no BGB em 2002.

A "Lei para a modernização do Direito das obrigações" realizou significativas alterações no Código Civil alemão e, no que diz respeito à violação positiva do contrato, preencheu a lacuna legislativa até então existente. A reforma, todavia, não mencionou o instituto, o qual foi dispersado em previsões normativas específicas, dentre as quais se destacam os arts. 280 e 281 do BGB $^{190}$ que tratam da caracterização do inadimplemento. Como consequência das novas prescrições, o emprego da violação positiva do contrato na Alemanha caiu em desuso ${ }^{191}$.

Tendo em vista as particularidades da mora no sistema brasileiro e também a superação da violação positiva do contrato em seu país de origem, pode-se concluir pela não conveniência da adoção desta figura no Brasil, uma vez que as hipóteses por ela abrangidas já são tratadas de maneira suficiente pela mora.

Independentemente da posição adotada, interessante notar que a violação positiva do contrato, caso admitida para as hipóteses de violação dos deveres anexos, pouco abrangeria quando se está diante do descumprimento ocorrido no âmbito do contrato de distribuição.

Neste tipo negocial, os deveres comumente caracterizados como laterais são, geralmente, colocados para dentro do contrato por meio de estipulações das partes, tornando, assim, deveres de prestação.

\footnotetext{
${ }^{190}$ Cf. CORDEIRO, António Menezes. A modernização do direito das obrigações - aspectos gerais e reforma da prescrição. ROA, Ano 62, n. ${ }^{\circ}$ I, Lisboa, Janeiro de 2002. p. 91-110; e CORDEIRO, António Menezes. A modernização do direito das obrigações - o direito da perturbação das prestações. ROA, Ano 62, n. ${ }^{\circ}$ I, Lisboa, Abril de 2002. p. 319-345.

${ }^{191}$ Segundo a doutrina, "Em razão do atual regramento do inadimplemento nos $\S \S 281$ e 323, na parte geral do direito das obrigações, deixou de existir a lacuna ocupada pela violação positiva do contrato antes da reforma do direito das obrigações. A perturbação da prestação atualmente regrada pelo § 280 não deve mais ser descrita como violação "positiva" do contrato". (Tradução livre de "Auf Grund der nun mehr ausdrücklichen gesetzlichen Regelung der Schlechterfüllung in den $\S \S 281,323$ im allgemeinen Teil des Schuldrechts ist die Regelungslücke, die vor der Schuldrechtsreform für die Anwendbarkeit der positiven Forderungsverletzung bestand, insoweit geschlossen worden. Die heute in $\S 280$ geregelte Leistungsstörung sollte nicht mehr als "positive" Vertrags- oder Forderungsverletzung bezeichnet werden". (Cf. BROX, Hans; WALKER, Wolf-Dietrich. Allgemeines Schuldrecht, 34. aktualisierte Auflage, München: C. H. Beck, 2010. p. 285).
} 
É o caso, por exemplo, do dever de informar. Na maioria dos contratos não classificados como de colaboração, o dever de informar decorre da boa-fé. No contrato de distribuição, por sua vez, o dever de informar está intrinsecamente relacionado à economia do negócio. $\mathrm{O}$ atendimento do fim do contrato necessita que o distribuidor informe ao fornecedor as condições e demandas do tráfico, uma vez que este, ao optar pelo sistema de vendas indireta, reduz seu contato imediato com o mercado.

O dever de cuidado com o patrimônio do contratante encontra-se, igualmente, acentuado em contratos de colaboração tal qual a distribuição. Isto é evidenciado com a concessão de uso da marca. $\mathrm{O}$ fornecedor permite que o distribuidor valha-se da imagem de sua marca, em contrapartida, este assume o compromisso de zelar por ela.

A violação positiva do contrato não se aplica, portanto, ao direito brasileiro. Mesmo diante daqueles que defendem sua aplicação para as hipóteses de infração aos deveres anexos, a violação positiva do contrato tem um âmbito de aplicação extremamente reduzido no contrato de distribuição, o qual, por se enquadrar como contrato de colaboração, traz deveres relacionados à lealdade e confiança entre suas prestações.

Neste cenário, diante do descumprimento das obrigações, dois caminhos são possíveis, a depender da análise acerca da utilidade da prestação, quais sejam: mora ou inadimplemento definitivo. $\mathrm{O}$ exame da mora já foi realizado de modo que convém, neste momento, cuidar do inadimplemento definitivo.

\section{Inadimplemento definitivo}

A mora, como visto, é o descumprimento da prestação no tempo, lugar e forma devidos. Abrange o não cumprimento da obrigação principal ou anexa, ou o seu cumprimento defeituoso, desde que imputáveis ao devedor e até que permaneça a possibilidade de cumprimento útil da prestação para o credor.

Nem sempre, entretanto, o descumprimento comporta emenda. Quando não mais subsiste para o credor a possibilidade de receber a prestação - isto é, a prestação não foi cumprida, nem mais poderá sê-lo ${ }^{192}$ - caracteriza-se o inadimplemento definitivo (ou absoluto).

${ }^{192}$ Cf. AlviM, Agostinho. Da inexecução das obrigações, op. cit., p. 44- 45. 
O descumprimento torna-se irremediável seja em virtude de impossibilidade superveniente imputável ao devedor, seja devido à perda da utilidade da prestação ao credor $^{193}$.

Haverá inadimplemento definitivo quando o devedor em mora perde os bens guardados em depósito em virtude de incêndio, impossibilitando o cumprimento. $\mathrm{O}$ inadimplemento definitivo resta caracterizado ainda quando as mercadorias que seriam entregues e, posteriormente, carregadas em um navio não são entregues na data pactuada e, assim, o navio parte sem os produtos, tornando inútil o cumprimento posterior da prestação.

O inadimplemento definitivo, embora comumente relacionado à violação dos deveres de prestação, abrange também o cumprimento defeituoso das prestações bem como a infração dos deveres laterais. Pode, além disso, recair sobre uma parcela ou a integralidade da prestação.

Diante do descumprimento contratual, surgem, assim, dois caminhos, quais sejam mora e inadimplemento definitivo. Cumpre ressaltar que nos contratos de duração, entre os quais se enquadra o contrato de distribuição, a mora tende a ocorrer de maneira mais corriqueira que o inadimplemento definitivo. Como o negócio irá se protrair no tempo, ainda que ocorra o descumprimento, ainda será viável, na maioria das vezes, sua purgação ou emenda, sem que isso comprometa definitivamente o programa contratual.

A distinção entre mora e inadimplemento definitivo é de fundamental relevância, uma vez que as consequências são diversas para uma ou outra situação. Convém, deste modo, examinar como a mora transforma-se em inadimplemento definitivo.

\subsection{Transformação da mora em inadimplemento definitivo}

A demarcação dos limites entre mora e inadimplemento definitivo depende da manutenção da utilidade da prestação para o credor. Este critério encontra-se previsto no parágrafo único do art. 395 do Código Civil, o qual, em razão de sua importância para o trabalho, aproveita transcrever: "Art. 395, parágrafo único. Se a prestação, devido à mora,

${ }^{193}$ Cf. Costa, Mário Júlio de Almeida. Direito das obrigações, op. cit, p. 1.034. 
se tornar inútil ao credor, este poderá enjeitá-la, e exigir a satisfação das perdas e danos ${ }^{194,}$ (destaque nosso).

Identificar a transformação da mora em inadimplemento definitivo no contrato de distribuição não representa, porém, uma tarefa fácil ${ }^{195}$. O mencionado dispositivo do Código Civil estabelece o critério a ser utilizado, no entanto, as regras são vocacionadas aos contratos de execução instantânea e sua aplicação aos contratos de duração requer cuidados.

Esta dificuldade é própria aos contratos de duração, categoria na qual se filia a concessão comercial. Nestes negócios, caso uma prestação não tenha sido realizada no tempo, no lugar ou modo convencionado, a longa duração do contrato pode estender a possibilidade de seu cumprimento útil.

Isto porque o tempo apresenta inúmeras facetas no Direito contratual e influencia não apenas na vigência do contrato, mas também na forma de sua execução ${ }^{196}$. O tempo, no que mais de perto interessa ao presente trabalho, interfere diretamente na valoração da utilidade da prestação.

A inutilidade que decorre do inadimplemento pode ser facilmente percebida através de um exemplo. Se o distribuidor deve promover a propaganda de uma coleção de produtos destinada a um período específico (Copa do Mundo, por exemplo) e não o faz, a prestação perde sua utilidade. Não há que se falar em mora do distribuidor. A prestação tornou-se inútil e configura inadimplemento definitivo.

A apuração da utilidade, no entanto, revela-se complexa quando a mesma obrigação deve ser observada durante toda a vigência do contrato. Neste caso, o atraso de um mês pode configurar simples mora em um negócio com duração de dez anos, posto que a publicidade, normalmente, ainda será útil, a despeito da delonga.

A utilidade da prestação, desta maneira, é critério demasiadamente amplo quando se está diante de um contrato de duração. Resta, assim, oportuno identificar parâmetros que

\footnotetext{
${ }^{194}$ Segundo Judith Martins-Costa o parágrafo único do art. 395 traz um ponto de partida para se alcançar, diante do problema concreto, o que é mora e o que é inadimplemento definitivo. Há, por isso, um topos da utilidade/inutilidade. (Cf. MARTINS-CostA, Judith. Comentários ao novo Código, op. cit., p. 358-359).

195 A doutrina alerta para este cenário, conforme se depreende da seguinte passagem: "Em certas configurações contratuais é particularmente delicada a apreensão da "inutilidade" da prestação. Tal ocorre em certos contratos atípicos e nos reunidos por conexão finalista, como os "grupo de contrato" e os "contratos combinados", as "galáxias" e as "redes contratuais" ou quando há complexidade ínsita, tal qual exemplificado pelo contrato de distribuição". (Cf. MARTins-Costa, Judith. Comentários ao novo Código, op. cit., p. 366).

${ }^{196}$ Cf. MARTINS-CostA, Judith. Comentários ao novo Código, op. cit., p. 33.
} 
auxiliem na qualificação da inutilidade da prestação e, consequentemente, na caracterização do inadimplemento definitivo em um contrato que se protrai no tempo.

6.2. Critérios para aferir a utilidade da prestação

Os tipos contratuais prestam-se a oferecer um modelo jurídico para disciplinar dada operação econômica. $\mathrm{O}$ contrato de distribuição, por exemplo, destina-se à colocação de produtos no mercado através do sistema de vendas indiretas.

A apuração da utilidade de uma prestação deve considerar, deste modo, a função econômica do contrato descumprido. O exame deve recair ainda sobre o pactuado pelas partes na declaração negocial e os usos setoriais.

Sem descurar das peculiaridades que possam se fazer presentes em razão dos ramos de atividade nos quais se emprega o contrato de distribuição, compete ir mais adiante para que a investigação não se restrinja ao mero casuísmo. Convém, em particular, recorrer a quatro critérios interpretativos destinados a aclarar os limites da utilidade no contrato de distribuição. É do que se passa a cuidar.

\subsubsection{Perda de mercado}

O sucesso do negócio ora objeto de estudo depende, em última análise, da colocação dos produtos no mercado. Esta tarefa dirige as obrigações tanto do fornecedor quanto do distribuidor. Trata-se, em suma, da função econômica do contrato de distribuição.

A colocação dos produtos no mercado e, mais precisamente, a perda do mercado apresenta-se, assim, como o primeiro critério a ser empregado na interpretação do topos da utilidade da prestação.

A perda de participação que exclua definitivamente o produto de seu respectivo nicho mina o fim do contrato e, consequentemente, ensejará a resolução, conforme se analisará mais detidamente na segunda parte do trabalho.

A perda do mercado, no entanto, nem sempre será irreversível. É perfeitamente possível que a parcela perdida seja recuperada, de modo que este critério isoladamente não basta para determinar a inutilidade da prestação. Tal critério deve ser combinado com outros, a fim de auxiliar na qualificação da utilidade da prestação. 


\subsubsection{Extensão temporal}

Os contratos de distribuição, conforme classificação desenvolvida no primeiro capítulo do presente trabalho, enquadram-se na modalidade dos contratos de duração. Sua estrutura, deste modo, é desenhada para se projetar no tempo.

A extensão temporal desempenha papel essencial para a fixação da transformação da mora em inadimplemento definitivo. $O$ interesse útil do credor varia conforme a duração do negócio seja maior ou menor. Afinal, é certamente diverso celebrar um contrato com vigência por dois, cinco ou dez anos.

Um atraso de seis meses na entrega das especificações técnicas dos produtos por parte do fornecedor configurará simples mora em contrato cuja duração foi estipulada para cinco anos. Idêntico retardo deverá, entretanto, receber tratamento jurídico diverso, frente a um negócio com duração de apenas um ano. Neste caso, a ausência de tais especificações prejudica gravemente a revenda dos produtos por parte do distribuidor e configurará inadimplemento definitivo, prejudicando o fim do contrato.

Estes exemplos evidenciam o caráter dinâmico da mora e corroboram a necessidade de se combinar os critérios aqui elencados para a correta solução do inadimplemento ocorrido no caso concreto.

\subsubsection{Conjuntura de mercado}

Todo contrato é pactuado em dado contexto de mercado e, por conseguinte, não seria prudente ignorá-lo como critério interpretativo. O critério da perda de mercado deve ser balizado, assim, com as conjunturas de mercado para se aferir a reversibilidade ou a irreversibilidade da perda.

Vale anotar que a concorrência no contrato de distribuição se dá tanto no mercado entremarcas quanto no intramarcas. A perda de participação pode ocorrer, deste modo, em relação a outras marcas que disponibilizam produtos semelhantes no mercado bem como, na relação entre distribuidores de uma mesma rede.

O descumprimento contratual ocorrido em ambiente de pouca concorrência pode não afetar permanentemente a participação dos contratantes no mercado. A perda de mercado terá, portanto, natureza reversível. O descumprimento contratual ocorrido em ambiente de forte concorrência, diferentemente, poderá causar uma perda irreversível de mercado. 


\subsubsection{Custos}

O último critério destinado a aclarar o topos da utilidade no contrato de distribuição relaciona-se aos custos para sanar as consequências do inadimplemento.

A purgação do descumprimento contratual, por vezes, exige esforços financeiros, por parte do contratante fiel, tão elevados que a manutenção do contrato deixa de ter sentido. Os custos para recuperar o descumprimento afiguram-se superiores ao que o contrato pode gerar.

Esta situação apresenta-se, por exemplo, quando a imagem de uma marca é tão prejudicada por condutas do distribuidor que o custo para retomá-la inviabiliza o próprio contrato, preferindo o fornecedor sair do mercado. $\mathrm{O}$ descumprimento afeta de tal modo o pactuado que altera, assim, a economia contratual.

Estes critérios forneceram alguns parâmetros para resolver uma das maiores dificuldades havidas na disciplina do inadimplemento do contrato de distribuição. Esta dificuldade relaciona-se ao enquadramento deste tipo negocial na categoria dos contratos de duração. Diante desta modalidade de negócio, os critérios legais da possibilidade e utilidade reclamam complementação o que se dá através dos critérios indicados.

A determinação de alguns critérios para distinguir a mora do inadimplemento definitivo põe fim a caracterização desta modalidade de descumprimento, o que torna oportuno principiar o exame de suas consequências.

\subsection{Consequências}

Diante do inadimplemento definitivo, apresentam-se ao contratante inocente duas alternativas, nos termos do art. 475 do Código Civil. A escolha entre uma ou outra via cabe à parte lesada pelo inadimplemento ${ }^{197}$.

A parte inocente, em primeiro lugar, pode optar pela execução do contrato. Neste caso, o cumprimento não se dará, por óbvio, pela execução específica, posto que a prestação tornou-se para sempre irrealizável diante do inadimplemento definitivo.

Trata-se de cumprimento por uma prestação equivalente, de natureza pecuniária, que visa a substituir a prestação que se tornou para sempre irrealizável. A arras e a cláusula penal são exemplos de prestação substitutiva.

${ }^{197}$ Cf. Carvalho Santos, J. M. Código Civil brasileiro interpretado. Vol. XV, 9a ed., Rio de Janeiro: Freitas Bastos, 1978. p. 249 e ASSIS, Araken de. Comentários ao Código Civil brasileiro, op. cit., p. 609 610. 
A prestação substitutiva permite ao contratante inocente obter o resultado que projetara e lhe foi negado pelo inadimplemento alheio. O cálculo da indenização, em razão disso, é voltado a colocar o credor na condição que se encontraria caso o contrato tivesse sido integralmente cumprido.

$\mathrm{O}$ art. 475 prescreve ainda que o credor pode optar pela resolução da relação contratual. A resolução põe fim ao vínculo entre as partes de maneira retroativa e, por consequência, a indenização, cumulada com ela, visa a colocar o lesado na situação que se encontraria caso o contrato não houvesse sido celebrado.

\section{Conclusões preliminares e caminhos do estudo}

O capítulo dedicou-se a examinar o inadimplemento recíproco ocorrido no âmbito de um contrato de distribuição. $\mathrm{O}$ inadimplemento recíproco abrange as hipóteses de descumprimento, por ambas as partes, de quaisquer deveres emanados do vínculo, sejam eles interdependentes ou não.

Trata, portanto, de situações como a enfrentada por uma distribuidora de bebidas que, contrariando o estabelecido no contrato, passa a vender produtos de outra marca, ao passo que a fornecedora quebra a exclusividade territorial e abre, para venda direta, um estabelecimento na mesma localidade. Ou, ainda, uma distribuidora de produtos luxuosos que os vende a preços que, de tão baixos, aviltam o bom nome da marca, enquanto a fornecedora exige a compra excessiva de peças para estoque.

Neste cenário, tornou-se necessário analisar as modalidades de descumprimento passíveis de ocorrência durante a vida do contrato. Identificar corretamente tais espécies afigura-se imprescindível para o bom andamento do trabalho, uma vez que há uma consequência legal distinta para cada espécie de descumprimento.

No modelo jurídico preconizado no sistema pátrio, o inadimplemento das obrigações conduz unicamente a dois caminhos, quais sejam, mora ou inadimplemento definitivo, conforme possibilidade da prestação e a utilidade desta ao credor. Afasta-se, deste modo, a conveniência da adoção da violação positiva no direito brasileiro ou, ao menos, a sua incidência nas hipóteses de descumprimento do contrato de distribuição.

Vale ressaltar que o capítulo dedicou-se ainda em fixar alguns critérios que podem ser empregados pelo intérprete do direito em vigor para complementar o conceito de utilidade previsto no parágrafo único do art. 395 do Código Civil, uma vez que a aferição 
do momento em que a prestação perde a utilidade revelou-se particularmente complexa nos contratos de duração.

A caracterização do inadimplemento recíproco no contrato distribuição é item que encerra a Primeira Parte do trabalho. Todo o esforço teórico empreendido nesta parte da pesquisa teve como propósito moldar o inadimplemento recíproco ocorrido no âmbito deste tipo contratual, o qual, conforme já se pode notar, poderá assumir diversas configurações.

Isto significa dizer, por outras palavras, que o descumprimento pode atingir qualquer um dos deveres previstos no contrato de distribuição e estará revestido por uma das duas modalidades previstas no ordenamento.

Pode-se estar diante, deste modo, de um inadimplemento definitivo de uma obrigação de $3^{\circ}$ grau cometido por um contratante e, de outro, da mora de uma obrigação que compõe o núcleo do tipo negocial. É possível ainda que o descumprimento recíproco recaia sobre obrigações de $2^{\circ}$ grau nas modalidades, respectivamente, mora $\mathrm{e}$ inadimplemento definitivo.

Caracterizados os institutos envolvidos, a Segunda Parte do presente esforço teórico objetiva aferir as consequências do inadimplemento recíproco no contrato de distribuição. Mais precisamente, procura, em um primeiro momento, equacionar as consequências previstas pelo ordenamento jurídico para as hipóteses de mora e inadimplemento definitivo, especialmente em razão das particularidades que emergem de seu enquadramento como contrato de duração e de colaboração.

Após examinar as consequências previstas no ordenamento pátrio para o inadimplemento, o trabalho passa a investigar, por fim, as consequências do descumprimento recíproco ocorrido no contrato de distribuição. 
PARTE II - CONSEQUÊNCIAS 


\section{CAPÍTULO 1 - AS REPERCUSSÕES DO INADIMPLEMENTO}

\section{Introdução}

Para satisfazer o propósito da segunda parte do trabalho, faz-se necessário, primeiramente, identificar e examinar as consequências previstas no ordenamento jurídico para o inadimplemento das obrigações.

A partir de um estudo aplicado ao contrato de distribuição, o capítulo pretende, mais precisamente, realizar uma análise sistemática do tema ao combinar as modalidades de inadimplemento - mora e inadimplemento definitivo - às respectivas consequências. $\mathrm{O}$ capítulo dedica-se, assim, à realização coativa da prestação, à execução pelo equivalente, à resolução, às perdas e danos e à exceção do contrato não cumprido.

A realização coativa da prestação é cabível quando a prestação não foi cumprida, mas ainda é possível, não excessivamente onerosa e útil ao credor ${ }^{198}$. Sua aplicação para todas as obrigações do contrato de distribuição merece, porém, ponderações, uma vez que o sucesso do referido negócio pressupõe a colaboração entre as partes.

Quando a execução da prestação descumprida torna-se para sempre irrealizável, o credor pode optar entre uma prestação equivalente e a resolução. A execução pelo equivalente substitui a prestação e terá natureza pecuniária.

A resolução é outra consequência possível diante do inadimplemento obrigacional. O exame do contrato de distribuição revelou, porém, que as obrigações que formam este tipo negocial assumem relevância diversa na economia do contrato e, neste cenário, convém investigar se todo descumprimento deve conduzir a tal medida. Cumpre, por outras palavras, identificar qual espécie de obrigação descumprida pode acarretar a resolução da relação contratual.

O efeito geral e típico do inadimplemento das obrigações, nos termos do art. 389 do diploma civil, é a responsabilidade pelo pagamento de perdas e danos. O ressarcimento será devido em razão de qualquer prejuízo ocasionado pela inexecução contratual, seja ele causado por mora ou inadimplemento definitivo, e será cumulado, inclusive, com as consequências antes anotadas.

${ }^{198}$ Cf. Martins-Costa, Judith. Comentários ao novo Código Civil, op. cit., p. 140. 
A composição das perdas e danos, entretanto, não será idêntica em todas as situações. Faz-se conveniente verificar, assim, as diferenças existentes e, para tanto, vale recorrer aos conceitos de interesse contratual positivo e negativo.

Há, por fim, uma última consequência do inadimplemento obrigacional. Trata-se da exceção do contrato não cumprido. Tal medida está intrinsecamente relacionada com os contratos bilaterais e permite que o contratante subordine seu próprio adimplemento ao cumprimento alheio. Cumpre, assim, verificar em quais hipóteses é possível o manejo de tal figura no contrato de distribuição.

Aclarado o conteúdo do capítulo, aproveita aprofundar o estudo destas consequências, bem como dos problemas que se apresentam diante do descumprimento do contrato de distribuição. É do que se passa a tratar nas linhas a seguir.

\section{Realização coativa da prestação}

A realização coativa da prestação é uma das consequências do inadimplemento obrigacional. A despeito da ausência de dispositivo específico no Código Civil, não resta dúvida que tal medida encontra-se consagrada no ordenamento jurídico.

Os pactos nascem para ser cumpridos. O direito do credor de exigir o cumprimento exatamente conforme o convencionado decorre da força obrigatória dos contratos. A realização coativa da prestação funda-se no princípio há muito reconhecido do pacta sunt servanda e assegura, apesar de tardio e forçado, o cumprimento.

A realização coativa da prestação, deste modo, tem lugar se a obrigação, depois de vencida, não é cumprida pelo devedor no tempo, lugar ou modo convencionados. Neste caso, o credor pode exigir judicialmente o cumprimento, valendo-se para tanto de um processo de conhecimento. Por outro lado, se houver um título executivo que ateste a existência do direito alegado, o credor pode recorrer diretamente ao processo de execução, conforme disposto nos arts. 550 e seguintes do Código de Processo Civil. Em adição, para o caso da obrigação de pagamento ou de entrega de coisa, o credor também poderá manejar a ação monitória, nos termos dos arts. 1.102 e seguintes do Código de Processo Civil.

A realização coativa da prestação é, assim, uma das consequências do inadimplemento contratual. Cumpre, então, identificar qual descumprimento pode ensejála. A inexecução, de acordo com o ordenamento pátrio, resume-se a duas modalidades, quais sejam mora e inadimplemento definitivo. 
Na mora, ainda que a prestação não tenha sido executada, subsiste a possibilidade de cumprimento ulterior. Nem sempre, todavia, o cumprimento ulterior é factível, seja em razão da impossibilidade superveniente da prestação, seja devido à perda da utilidade da prestação para o credor. Nesta hipótese, caracteriza-se o inadimplemento definitivo.

A interpretação do Código Civil revela, assim, que a realização coativa é consequência da mora, posto que a prestação não realizada ainda o pode ser por continuar possível e útil ao credor. A realização coativa almeja, assim, o cumprimento, embora este seja tardio e forçado. De outro lado, não há que se falar em realização coativa diante do inadimplemento definitivo, uma vez que, neste, a prestação tornou-se para sempre irrealizável.

Não cumprida a obrigação no tempo, lugar ou modo convencionados pode o credor exigir, deste modo, sua realização coativa. No contrato de distribuição, diante do não cumprimento imputável da obrigação, o contratante inocente poderá valer-se dos três meios conferidos pelo ordenamento para obter a realização coativa da prestação, a saber, o processo de conhecimento, o processo de execução e o processo monitório, conforme se façam presentes os respectivos pressupostos.

A obrigação de pagamento a cargo do distribuidor serve a ilustrar a afirmação. Se o contrato for verbal, o fornecedor poderá exigir o adimplemento por meio de ação de conhecimento. Se houver prova escrita sem eficácia de título executivo, poderá ajuizar a ação monitória. Se o título se enquadrar em uma das hipóteses do art. 585 do Código de Processo Civil, o fornecedor poderá, por fim, passar diretamente ao processo de execução.

O trabalho, conforme cumpre desde logo aclarar, dedicar-se-á de maneira mais aprofundada à análise da execução específica no contrato de distribuição, optando, por conveniência metodológica, excluir de sua investigação os problemas suscitados pelas obrigações que reclamam liquidação.

Neste momento, importante notar que o credor, além da prestação requerida através da execução específica, poderá exigir a reparação dos prejuízos que sofreu por não ter recebido a prestação no tempo, no lugar ou na forma devida, nos termos do art. 395 do Código Civil. Trata-se do efeito geral e típico do inadimplemento das obrigações.

Vale, a título ilustrativo, pensar no descumprimento pelo fornecedor da obrigação de não concorrência, ao atuar diretamente na área exclusiva do distribuidor mediante a instalação de uma filial. Nesta hipótese, a execução específica garante o desfazimento do ato. Além do desfazimento do ato, o distribuidor deverá ainda ser ressarcido pelos prejuízos que sofreu em virtude da atuação do fornecedor. Esta indenização pretende 
colocar o contratante na posição que estaria caso o contrato houvesse sido devidamente cumprido.

A execução específica, à qual se soma a indenização pelos prejuízos havidos, é, assim, a primeira consequência do descumprimento das obrigações. Cumpre observar, porém, que as obrigações presentes no contrato de distribuição assumem diversos contornos, o que produz relevantes efeitos sobre a execução específica.

No contrato de distribuição, pode-se estar diante de uma obrigação de fazer, tal qual a obrigação do distribuidor de revender os produtos. A exclusividade territorial é exemplo, por sua vez, de uma obrigação de não fazer, porquanto representa para o fornecedor a obrigação de não concorrer com o distribuidor naquela determinada área. As obrigações de dar também figuram neste tipo negocial, merecendo destaque a obrigação assumida pelo fornecedor de entregar as mercadorias.

A execução específica em cada modalidade de obrigação assumirá contornos próprios, de maneira que se afigura conveniente investigar as características de cada uma delas nas linhas que seguem.

\subsection{Modalidades de obrigações}

As obrigações podem ser classificadas conforme vários critérios. São, por exemplo, divisíveis ou indivisíveis, conforme a prestação comporte ou não o seu fracionamento. Quanto ao número de sujeitos, podem ser ainda solidárias ou não. Entre estas várias classificações, merece destaque aquela fundada no objeto da prestação e que reúne as obrigações de dar, fazer e não fazer.

O contrato de distribuição, como investigado no primeiro capítulo deste trabalho, é composto por uma série de obrigações. Neste tipo negocial, é possível afirmar, de maneira bastante sucinta, que existem algumas obrigações de dar, cercadas por uma série de obrigações de fazer e, ainda outras, de não fazer. Esta composição das obrigações reflete a preocupação comum a todo negócio destinado a protrair-se no tempo de regrar, além das prestações essenciais, o comportamento das partes.

Nas linhas que seguem serão destacadas as particularidades da execução específica frente ao inadimplemento de cada espécie de obrigação presente no contrato de distribuição. Convém, desde logo, chamar a atenção para o descumprimento de uma obrigação de fazer, a qual pelas características a seguir expostas tende a provocar maiores embaraços para a execução específica. 


\subsubsection{Obrigações de dar}

As obrigações de dar são aquelas cujo conteúdo é a transferência de um direito ou a entrega de um bem ${ }^{199}$. Estas se dividem em dar coisa certa ou coisa incerta. A coisa certa é aquela individualizada, ou seja, suas características a distinguem das demais, não sendo possível encontrar em outras todos os seus atributos ${ }^{200}$.

É exemplo de obrigação de dar coisa certa a compra e venda do lote com as 20 últimas garrafas de dado vinho premiado, produzido em certa safra, por determinada vinícola.

Na obrigação de dar coisa certa, portanto, a prestação será cumprida apenas com a entrega de tal bem. Por tais características, fala-se também em obrigações específicas. $\mathrm{O}$ Código Civil de 1916, em razão disso, previa, nos termos de seu art. 863, que o credor não poderia ser obrigado a receber prestação diversa, ainda que mais valiosa. Igualmente, preceitua o art. 313 do atual diploma legal.

Por análoga razão, caso o bem se perca, não é possível a entrega de outro. A obrigação será resolvida ou o bem substituído por uma prestação equivalente de natureza pecuniária, conforme prevê o art. 234 do Código Civil. O art. 627 do Código de Processo Civil secunda tal entendimento.

A coisa incerta, por outro lado, é aquela que será indicada pelo gênero e pela quantidade, no termos do art. 243 do Código Civil. Trata-se da obrigação de entregar 20 caixas de vinho produzidas por certa vinícola. Estas obrigações são também chamadas de obrigações genéricas.

A obrigação de dar coisa incerta torna-se certa quando forem determinados os bens a serem prestados. Necessário, pois, proceder à concretização ${ }^{201}$ da coisa, o que cabe ao devedor, exceto se diversamente pactuarem as partes, conforme o art. 244 do diploma cível. Este deverá enviar a coisa média, isto é, não está obrigado ao melhor, nem poderá prestar o pior do gênero.

Vale observar, inclusive, que as obrigações de dar coisa incerta possuem dois regimes jurídicos. O primeiro aplicável até o momento da concretização. No segundo, que vai da concretização até a entrega da coisa, a obrigação transforma-se em certa e segue,

\footnotetext{
${ }^{199}$ Cf. Bianca, C. Massimo. Diritto Civile: l'obbligazione. Vol. 4. Milano Giuffrè, 1993. p. 108.

${ }^{200}$ Cf. PonTES DE MIRANDA, Francisco Cavalcanti. Tratado de direito privado, t. XXII. $3^{\mathrm{a}}$ ed., $2^{\mathrm{a}}$ reimp. São Paulo: Revista dos Tribunais, 1984. p. 86.

${ }^{201}$ Nas obrigações de dar, o emprego do termo concretização prefere ao termo concentração, mais adequado às obrigações alternativas (Cf. PONTES DE MIRANDA, Francisco Cavalcanti. Tratado de direito privado, t. XXII, op. cit., p. 102 e 108-112).
} 
portanto, as normas próprias a esta espécie de obrigação, como dispõe o art. 245 do Código Civil $^{202}$.

No contrato de distribuição, a obrigação de entregar mercadorias assumida pelo fornecedor caracteriza-se como uma obrigação de dar coisa incerta. Até mesmo em contrato de distribuição que contemple produtos de luxo ou de alta tecnologia, a obrigação de entregar é genérica. A obrigação de um fornecedor que se comprometeu a entregar dados anéis de noivado torna-se certa apenas no momento em que é feita a concretização.

A concretização no contrato de distribuição, diversamente do que um exame apressado poderia sugerir, não ocorre por meio da realização dos pedidos pelo distribuidor. Ela se dá quando o fornecedor escolhe as mercadorias que enviará ao distribuidor e o comunica do envio ${ }^{203}$.

Para aclarar como ocorre a concretização neste tipo negocial, bem como definir o regime jurídico aplicável as obrigações de dar, vale recorrer a um exemplo. Dois empresários celebram um contrato de distribuição que tem por objeto a compra e posterior revenda de peças automotivas. O distribuidor, com vistas a atender as demandas do mercado e ainda cumprir a cláusula de aquisição mínima, realiza pedidos periodicamente. Sempre a título de ilustrativo, pode-se imaginar um pedido de 100 radiadores de dada marca e modelo, adequado a certos veículos.

O pedido apenas define a quantidade de produtos a ser entregues. Não houve ainda a concretização, o que produz importante reflexo no regime jurídico das obrigações de dar de coisa incerta. Antes da concretização, não poderá o devedor alegar perda ou deterioração da coisa, ainda que por força maior ou caso fortuito, conforme alerta o art. 246 do Código Civil.

Nesta hipótese, caso produto se perca em razão, por exemplo, de incêndio que atinge o estoque do fornecedor, este não se exime de entregar as mercadorias. São produtos genéricos, os quais o fornecedor deve substituir. Antes da concretização, portanto, todo o risco cabe ao devedor. Nada impede, porém, que as partes pactuem diversamente ${ }^{204}$.

Recebido o pedido pelo fornecedor, este deve selecionar os produtos que enviará ao distribuidor. Na seleção, o fornecedor não deve escolher os piores exemplares, tampouco

\footnotetext{
${ }^{202}$ Anota, de maneira esclarecedora, Pontes de Miranda: “As obrigações de dar coisa incerta são obrigações que têm a destinação da mudança, de se tornarem obrigações de dar coisa certa”. (Cf. PONTES DE MIRANDA, Francisco Cavalcanti. Tratado de direito privado, t. XXII, op. cit., p. 110-111).

${ }^{203}$ Esclarece a doutrina que "não basta que o devedor envie a coisa ao devedor: é preciso que ele faça saber ao que adimple, com a coisa enviada, a obrigação genérica". (Cf. PONTES DE MIRANDA, Francisco Cavalcanti. Tratado de direito privado, t. XXII, op. cit., p. 108).

${ }^{204}$ Cf. PONTES DE MIRANDA, Francisco Cavalcanti. Tratado de direito privado, t. XXII, op. cit., p. 107.
} 
se obriga a entrega dos melhores. Tratando-se de obrigação a ser cumprida no local de interesse do devedor, o fornecedor deve ainda comunicar o distribuidor do envio. É, neste momento, que ocorre a concretização, o que produz relevantes consequências no regime jurídico das obrigações de dar.

Com a concretização, a coisa incerta torna-se certa e deverá ser entregue pelo devedor. A execução para entrega da coisa, conforme preceitua a doutrina, baseia-se fundamentalmente no meio executório de desapossamento ${ }^{205}$. Tal entendimento é secundado pelo disposto nos arts. 621 e 625 do Código de Processo Civil.

O parágrafo único do citado art. 621 permite ainda que o juiz fixe astreientes para ver cumprida a obrigação. Estas constituem meio compulsório para impelir o devedor a prestar, mediante a imposição pelo juiz de uma multa para determinado período de tempo (por dia, mês) de atraso no cumprimento da obrigação ${ }^{206}$.

Na hipótese de perda do bem concretizado, não é possível a entrega de outro. Tratase de impossibilidade superveniente de prestar e, deste modo, a execução específica não mais tem cabimento.

Nestes casos, a obrigação será necessariamente resolvida, se a impossibilidade não for imputável ao devedor; ou, caso imputável, o bem será substituído por uma prestação equivalente de natureza pecuniária, além das perdas e danos cabíveis em ambas as situações, conforme estabelece o art. 234 do Código Civil e o art. 627 do Código de Processo Civil.

Vale recordar que também pode ter lugar, desde que observados os demais pressupostos, a resolução, com fundamento no art. 475 do Código Civil, do que decorre extinção da relação jurídica e o pagamento de perdas e danos.

Caso ocorra apenas a deterioração, o credor poderá aceitar sua entrega, mediante o abatimento do preço. Poderá ainda o credor exigir a substituição do bem deteriorado por uma prestação equivalente de natureza pecuniária ou optar pela resolução da obrigação, conforme o descumprimento seja imputável ou não ao devedor, nos termos dos arts. 235 e 236 do Código Civil.

Estas são as principais características da execução específica que recai sobre as obrigações de dar. De acordo com a tradicional classificação tripartite das obrigações, o próximo passo seria examinar as obrigações de fazer. Antes, porém, cumpre investigar

\footnotetext{
${ }^{205}$ Cf. Assis, Araken. Comentários ao Código de Processo Civil. Vol VI: arts. 566 a 645. Rio de Janeiro: Forense, 2009. p. 366.

${ }^{206}$ Cf. Assis, Araken. Comentários ao Código de Processo Civil, op. cit., p. 432-436.
} 
uma obrigação genérica em particular, em razão das peculiaridades de seu objeto e da grande importância que assume para a troca de riquezas. Trata-se da obrigação pecuniária $^{207}$.

\subsubsection{Obrigação pecuniária}

As obrigações pecuniárias são aquelas que possuem como objeto uma soma de dinheiro, tomada unicamente pelo seu valor monetário ${ }^{208}$. No contrato de distribuição, o distribuidor assume uma obrigação pecuniária ao adquirir mercadorias do fornecedor para a posterior revenda.

Esta espécie de obrigação não deve ser confundida com as obrigações de dar que também recaiam sobre dinheiro. Não caracteriza uma obrigação pecuniária a obrigação assumida por determinado sujeito de entregar 50 moedas de ouro datadas de certo ano. Trata-se, neste caso, de uma obrigação de dar.

Vale anotar que as obrigações pecuniárias, em razão de seu objeto, caracterizam-se por não se sujeitarem a impossibilidade superveniente da prestação ${ }^{209}$. Não há impossibilidade ainda que falte a moeda estipulada.

Basta pensar, por exemplo, em um contrato firmado no Brasil em 1993, cujo pagamento deveria ocorrer em dezembro de 1994 em Cruzeiro Real (CR\$), moeda corrente à época da celebração do contrato. Na data do pagamento, porém, a moeda do país mudara para o Real (R\$). Neste caso, não há que se falar em extinção da obrigação fundada em impossibilidade superveniente. A obrigação continua devida, mas seu cumprimento ocorrerá de acordo com os valores da nova moeda.

A execução específica das obrigações pecuniárias, nos termos do art. 646 do Código de Processo Civil, tem por objeto expropriar bens do devedor, a fim de satisfazer o direito do credor. Vale anotar que, antes de adjudicados ou alienados os bens, pode o executado remir a execução mediante o pagamento da importância atualizada da dívida, conforme dispõe o art. 651 do Código de Processo Civil.

Esclarecidas as peculiaridades das obrigações pecuniárias, dedicam-se as próximas linhas ao exame das obrigações de fazer.

\footnotetext{
${ }^{207}$ A doutrina costuma definir as obrigações pecuniárias como obrigações genéricas. A propósito, cf. CoSTA, Mário Júlio de Almeida. Direito das obrigações, op. cit., p. 735.

${ }^{208}$ Cf. Costa, Mário Júlio de Almeida. Direito das obrigações, op. cit., p. 735.

${ }^{209}$ Cf. BiancA, C. Massimo. Diritto Civile: l'obbligazione, op. cit., p. 146.
} 


\subsubsection{Obrigações de fazer}

As obrigações de fazer são aquelas que têm por objeto a realização de uma atividade material $^{210}$. No contrato de distribuição, há uma série de obrigações desta modalidade. Tais obrigações, de um lado, auxiliam diretamente na consecução dos fins do contrato e, de outro, fazem nascer deveres autônomos que promovem a integração e a colaboração entre as partes, de modo a preservar a duração do contrato.

A obrigação de prestar assistência técnica e de informar as condições do mercado são algumas das obrigações de fazer que correm sob responsabilidade do distribuidor. Ao fornecedor, por sua vez, compete prestar orientações técnicas e ainda oferecer treinamento.

Por muito se discutiu o cabimento da execução específica nos casos de descumprimento das obrigações de fazer. Inicialmente, não era possível à parte prejudicada exigir o estrito cumprimento do pactuado, restando somente o direito de ser ressarcida pelas perdas e danos sofridos ${ }^{211}$.

Atualmente, não resta dúvida sobre a possibilidade de tutela específica para o cumprimento de obrigações de fazer. A previsão da execução específica pode ser verificada pelo art. 632 do Código de Processo Civil, o qual dispõe que o devedor será citado para satisfazer a obrigação de fazer no prazo que o juiz lhe assinar ou, se houver, naquele determinado no título executivo.

Cumpre anotar, porém, que o procedimento para a execução específica das obrigações de fazer irá diferenciar-se conforme a natureza da prestação a ser cumprida. As obrigações de fazer dividem-se, deste modo, em fungíveis ou infungíveis.

Nas obrigações de fazer fungíveis, permanecendo a inércia do devedor, não importa que a prestação venha a ser cumprida por terceiros à custa do contratante inadimplente, pois, para o contratante fiel, basta apenas o cumprimento da prestação, ainda que praticada por outrem. É o que dispõe o art. 249 do Código Civil e também os arts. 633 e 634 do Código de Processo Civil.

Nesta modalidade de obrigação, é possível inclusive que o credor, independentemente de autorização judicial e em caso de urgência, execute ou mande executar o fato, sendo posteriormente ressarcido, conforme preceitua o parágrafo único do citado art. 249.

No contrato de distribuição, a obrigação de realizar publicidade caracteriza-se como fungível. Basta pensar, por exemplo, na obrigação, confiada ao distribuidor, de anunciar no

\footnotetext{
${ }^{210}$ Cf. Bianca, C. Massimo. Diritto Civile: l'obbligazione, op. cit., p. 113.

${ }^{211}$ Cf. Assis, Araken. Comentários ao Código de Processo Civil, op. cit., p. 397.
} 
jornal de maior circulação de sua área de atuação ou na colocação de um outdoor para divulgar os produtos objeto do contrato. Nesta hipótese, em caso de mora, pode o fornecedor mandar executar a obrigação à custa do distribuidor.

A obrigação de fazer pode caracterizar-se, por outro lado, como infungível e, neste caso, haverá cumprimento apenas com a realização da prestação pelo próprio devedor. Trata-se, em suma, de ato pessoal.

No contrato de distribuição, é o que ocorre com quem há de prestar determinadas informações sobre o mercado. Neste caso, havendo mora do distribuidor, é impossível que a obrigação seja executada por terceiros, ainda que à custa do contratante moroso. $\mathrm{O}$ cumprimento, deste modo, se dará apenas com a execução pelo distribuidor.

Nesta modalidade de obrigação de fazer, o credor deve valer-se de meios indiretos para ver cumprida a prestação, já que não pode constranger fisicamente o devedor a executá-la. Para tanto, o Código de Processo Civil prevê a possibilidade de cominação de astreintes pelo juiz, conforme se depreende do exame combinado dos arts. 461 e 644 do Código de Processo Civil.

$\mathrm{Na}$ hipótese de recusa no cumprimento da obrigação de fazer infungível, o cumprimento não mais ocorrerá pela prestação propriamente dita. Esta será substituída por uma prestação equivalente de natureza pecuniária, nos termos do art. 247 do Código Civil e art. 638 do Código de Processo Civil.

Nas linhas acima, tratou-se das principais características sobre a execução específica das obrigações de fazer. Estas, como visto, consistem na realização de dado comportamento. No contrato de distribuição, ao lado destas, coexistem outras obrigações, cujo conteúdo consiste em uma abstenção. São as obrigações de não fazer, cujo exame inicia-se a seguir.

\subsubsection{Obrigações negativas}

As obrigações negativas são aquelas que têm por objeto um comportamento omissivo do devedor, consistente em um não fazer ou não dar. No contrato de distribuição, assumem especial relevância as obrigações de não fazer, ou seja, aquelas obrigações nas quais o devedor assume, como prestação devida, não praticar determinado ato $^{212}$.

\footnotetext{
${ }^{212}$ Cf. Martins-Costa, Judith. Comentários ao novo Código Civil, op. cit., p. 245 e BiAnCA, C. Massimo. Diritto Civile: l'obbligazione, op. cit., p. 120.
} 
No contrato de distribuição, merecem destaque duas obrigações de não fazer. Trata-se da cláusula de exclusividade territorial, por meio da qual o fornecedor se obriga a não concorrer com o distribuidor em determinada área. O distribuidor, por sua vez, também pode assumir uma obrigação negativa ao pactuar a exclusividade de comercialização, pela qual se obriga a não vender produtos que concorram com aqueles do fornecedor.

O inadimplemento da obrigação de não fazer nasce justamente da prática do ato que o devedor deveria se abster. Há, assim, inadimplemento caso o fornecedor, obrigado a conceder exclusividade territorial, passe a atuar diretamente na região ou nela constitua novo distribuidor. Há, igualmente, violação contratual caso o distribuidor tenha se obrigado a não vender produtos de outras marcas e, a despeito disso, os venda.

Se o devedor realiza a prestação que deveria se abster, não há dúvida de que descumpriu o contrato e está inadimplente, conforme preceitua o art. 390 do Código Civil. Resta, então, saber qual a modalidade deste inadimplemento. Mais precisamente, necessário esclarecer se o descumprimento da obrigação negativa pode caracterizar mora ou apenas inadimplemento definitivo.

Uma parte da doutrina entende que há incompatibilidade entre a mora e as obrigações negativas. A inobservância destas obrigações daria lugar apenas ao inadimplemento definitivo, pois, uma vez praticado o ato proibido, violada estaria a obrigação $^{213}$.

Segundo outra parcela, a mora pode perfeitamente recair sobre obrigações negativas $^{214}$. Basta, para tanto, que persista a possibilidade de ser purgada, o que se dará com o desfazimento do ato ${ }^{215}$.

Tal entendimento melhor reflete a sistemática do inadimplemento presente no Código Civil, conforme demonstra especialmente o exame do art. 251, cujo texto aproveita

\footnotetext{
${ }^{213}$ Cf. AlviM, Agostinho. Da inexecução das obrigações, op. cit., p 133-134.

${ }^{214}$ Cf. PonTES DE MIRANDA, Francisco Cavalcanti. Tratado de direito privado, t. XXII, op. cit., p. 119. No mesmo sentido, cf. MARTINS-Costa, Judith. Comentários ao novo Código Civil, op. cit., p. 249.

${ }^{215}$ Ao interpretar o art. 1.222 do Código Civil de 1942, a doutrina italiana igualmente apresenta divergências. De acordo com parcela da doutrina peninsular, a mora nas obrigações de não fazer é inconcebível. Outros, diversamente, entendem que a mora abrange inclusive as obrigações negativas e anotam que a correta interpretação de tal dispositivo deve ter em consideração a forma de constituição da mora, a qual dispensa qualquer notificação nos casos de obrigação negativa, bastando para tal a realização do ato que o devedor deveria abster-se. O primeiro entendimento é adotado por QUERCI, Agnese. Inadempimento e obbligazioni negative. In VisinTiNI, Giovanna. Trattato della responsabilità contratuale. Vol. I. Padova: Cedam, 2009. p. 306-311. Em sentido diverso, cf. BIANCA, C. Massimo. Diritto civile: la responsabilità. Vol. 5. Milano: Giuffrè, 1994. p. 106-107.
} 
transcrever: "Praticado pelo devedor o ato, a cuja abstenção se obrigara, o credor pode exigir dele que o desfaça, sob pena de se desfazer à sua custa, ressarcindo o culpado perdas e danos".

Nas obrigações negativas, distinguem-se, deste modo, mora e inadimplemento definitivo, conforme persista a possibilidade e a utilidade do desfazimento do ato. A distinção da mora e do inadimplemento definitivo deve se basear, como nas demais obrigações, na possibilidade da prestação e na preservação de sua utilidade para o credor. Para a aferição da utilidade da prestação, convém recordar os critérios acima elencados, quais sejam: perda de mercado, extensão temporal, conjuntura de mercado e custos para retomar o cumprimento regular do contrato ${ }^{216}$.

Neste cenário, havendo mora de uma obrigação negativa, é possível que o credor exija o desfazimento coativo do ato. Cumpre anotar que, neste caso, a tutela específica assume contornos diversos daqueles encontrados nas obrigações de fazer e de dar, posto que se exige o desfazimento do ato. Não se trata, assim, de tutela com o objetivo de compelir o executado ao cumprimento, mas de execução para desfazer os efeitos materiais da transgressão do obrigado ${ }^{217}$.

O desfazimento do ato cuja realização o devedor deveria abster-se representa tutela específica típica das obrigações negativas. Tal medida encontra-se prevista no art. 251 do Código Civil, cujo parágrafo único garante ao credor inclusive o desfazimento do ato por conta própria ou mediante a contratação de terceiro, independentemente de autorização judicial, desde que haja urgência.

Em adição ao prescrito no Código Civil, os arts. 642 e 643 do Código de Processo Civil trazem as regras jurídicas para a concessão de tutela específica da obrigação de não fazer. Se procedente o pedido, o juiz fixará um prazo para o desfazimento do ato cuja realização o devedor deveria abster-se. Para o cumprimento de tal obrigação, é possível, ainda, a imposição de astreintes, nos termos do parágrafo único do art. 621 de referido diploma legal.

No caso, por exemplo, de descumprimento da cláusula de exclusividade de venda é possível que o fornecedor tenha satisfeito seu interesse mediante o desfazimento do ato, ou seja, com o fim das vendas dos produtos concorrentes pelo distribuidor e o fechamento da filial indevidamente instalada na localidade.

\footnotetext{
${ }^{216}$ Cf. item 6.2 do Capítulo 2 da Parte I do presente trabalho.

${ }^{217}$ Cf. Assis, Araken. Comentários ao Código de Processo Civil, op. cit., p. 425-426.
} 
Por outro lado, não sendo possível desfazer o ato, o descumprimento da obrigação negativa caracteriza inadimplemento definitivo. É o caso, por exemplo, de distribuidor que divulga informações sigilosas que se obrigou a resguardar.

Vale anotar que o enquadramento do contrato de distribuição como um contrato de duração influencia na possibilidade de ser purgada a mora decorrente da obrigação negativa. Nesta categoria de negócio, é possível que o credor adote o comportamento a cuja abstenção se obrigou e, em seguida, volte a observar a conduta devida. De outro lado, nos contratos de execução instantânea, a irreversibilidade do descumprimento caracterizase com maior facilidade.

Tal característica dos contratos de execução instantânea resta evidenciada na hipótese, por exemplo, de dado alienante desrespeitar a obrigação de não fazer que lhe era imposta pela pretérita concessão de direito de preferência em um contrato compra e venda, ao vender o bem a terceiro que apareceu com uma oferta particularmente mais vantajosa.

Por tudo o aqui exposto, as principais características da execução específica foram aclaradas. Identificou-se, mais precisamente, que se trata de consequência vocacionada a solucionar exclusivamente as hipóteses de mora no cumprimento das obrigações e, em adição, traçou-se um panorama geral de como se dá a execução específica nas obrigações de dar, fazer e não fazer que compõem o conteúdo do contrato de distribuição.

Concluído, pois, o exame da primeira consequência do inadimplemento, convém investigar as demais. É do que se passa a cuidar nas próximas linhas

\section{Execução pelo equivalente}

O descumprimento obrigacional de acordo com o ordenamento pátrio assume duas modalidades. Trata-se da mora e do inadimplemento definitivo. Diante da mora, é possível ao credor exigir a satisfação do respectivo interesse, uma vez que a prestação afigura-se ainda possível e útil, por meio da realização coativa da prestação.

Nos casos de inadimplemento definitivo já não cabe a realização coativa, pois a prestação tornou-se para sempre irrealizável, seja em virtude de impossibilidade superveniente, seja pela perda da utilidade de tal prestação para o credor. 
Cumpre, em verdade, ressaltar que nos contratos de duração, entre os quais se enquadra o contrato de distribuição, o tempo do negócio afeta sobremaneira a caracterização da mora e do inadimplemento definitivo $^{218}$.

Nesta categoria de contrato, a mora tende a ocorrer de maneira mais corriqueira que o inadimplemento definitivo. Como o negócio irá se protrair no tempo, ainda que sobrevenha o descumprimento, ainda será viável, na maioria das vezes, sua purgação ou emenda, sem que isso comprometa definitivamente o programa contratual.

Isso se vê, por exemplo, no caso da obrigação de adquirir cota mínima de mercadorias. Como regra, o atraso no cumprimento não põe em xeque a satisfação do interesse do credor, pois a aquisição tardia tende a ser suficiente para assegurar os resultados próprios à operação econômica, dentre as quais figura, com particular importância, a colocação de produtos em dado nicho de mercado.

O descumprimento desta categoria de negócio tende, em virtude disto, ser solucionado, na maioria dos casos, através da realização coativa da prestação, consequência prevista para a mora.

Não há que se falar, porém, em execução específica quando, por exemplo, a coisa a ser entregue se perde no caminho, em razão de incêndio que atinge o vagão do trem que está a transportá-la até o distribuidor. Igualmente, não cabe execução específica diante do descumprimento do distribuidor em realizar publicidade destinada a um período específico já encerrado.

Nestas hipóteses, apresentam-se ao contratante inocente, além das perdas e danos, duas alternativas a serem por ele escolhidas, conforme prescreve o art. 475 do Código Civil, cujo texto aproveita transcrever: "A parte lesada pelo inadimplemento pode pedir a resolução do contrato, se não preferir exigir-lhe o cumprimento, cabendo, em qualquer dos casos, indenização por perdas e danos".

É possível, deste modo, que o contratante fiel opte pela chamada execução pelo equivalente ou ainda pela resolução da relação jurídica contratual ${ }^{219}$. Cabe, neste momento, explorar as características da execução pelo equivalente enquanto a segunda hipótese será examinada no item a seguir.

\footnotetext{
${ }^{218}$ As dificuldades para a configuração do inadimplemento definitivo nos contratos de duração foram objeto de estudo detalhado em exame empreendido a partir do item 6 do Capítulo 2 da Parte I do presente trabalho.

${ }^{219}$ Cf. Martins-Costa, Judith. Comentários ao novo Código, op. cit., p.140. No mesmo sentido, o O Tribunal de Justiça do Estado de São Paulo, no mesmo sentido, entendeu que a resolução é possível apenas diante do inadimplemento definitivo, não podendo a mora ensejar o exercício deste direito. Segundo o aresto, "o inadimplemento relativo funciona como um limitativo desse direito, forçando o credor a exigir o cumprimento da avença". (TJSP, Ap. Civ. no 9204284072006826, 30ª Câm. Dir. Priv., r. Des. Andrade Neto, j. 21.09.2011).
} 
A execução pelo equivalente não pretende o cumprimento da prestação de maneira coativa, uma vez que esta se tornou para sempre irrealizável diante do inadimplemento definitivo. Por meio dela, o contratante inocente pode obter o resultado projetado que lhe foi negado pelo inadimplemento alheio através de uma prestação de natureza pecuniária.

A execução pelo equivalente efetiva-se por meio de uma prestação de natureza pecuniária que substitui a prestação inicialmente prevista. Trata-se, em suma, de "equivalente econômico-jurídico ${ }^{220 "}$ " que a lei coloca em lugar da prestação que se tornou irrealizável. Há, portanto, uma transformação da relação obrigacional ao substituir a prestação inicialmente pactuada, que se tornou inútil ou impossível, por uma prestação equivalente de natureza pecuniária ${ }^{221}$.

A título ilustrativo pode-se pensar na obrigação de entregar mercadorias a cargo do fornecedor que tenha se tornado inútil pelo grande atraso. Nesta hipótese, o distribuidor poderá exigir valor equivalente ao que tais mercadorias teriam na data da entrega.

Além da prestação equivalente, o credor poderá requerer ainda indenização dos danos sofridos em razão do inadimplemento alheio. A indenização, assim, é acrescida à prestação equivalente e seu cálculo é voltado a colocar o credor na condição que se encontraria caso o contrato tivesse sido devidamente cumprido.

Para continuar com o exemplo anterior, em adição ao valor das mercadorias, o distribuidor poderá reclamar o ressarcimento pelos lucros que deixou de auferir por não têlas podido vender, como ocorreria se a prestação tivesse sido cumprida a tempo.

Expostos os principais aspectos da execução pelo equivalente, cumpre investigar a segunda consequência passível de ocorrência diante do inadimplemento definitivo. Tratase da resolução contratual.

\section{Resolução}

O contratante fiel, diante do inadimplemento definitivo de sua contraparte, poderá optar, como visto, pela execução pelo equivalente ou pela resolução. Na hipótese de a execução pelo equivalente não lhe convir, o credor pode, assim, optar pela resolução da relação contratual.

\footnotetext{
${ }^{220} \mathrm{O}$ termo equivalente econômico-jurídico é empregado por ANTUNES VARELA, João de Matos. Das obrigações em geral, Vol. II, op. cit., p. 152.

${ }^{221}$ Cf. Antunes VARela, João de Matos. Das obrigações em geral, Vol. II, op. cit., p. 151-152.
} 
A resolução põe fim à relação jurídica contratual e produz dois efeitos principais. Primeiramente, permite ao contratante inocente se liberar do cumprimento de suas respectivas obrigações. Trata-se da eficácia liberatória.

Como consequência, a partir da resolução, as partes não estão mais obrigadas a cumprir o pactuado. Resolvido o contrato de distribuição por inadimplemento definitivo da obrigação assumida pelo fornecedor de entregar mercadorias, por exemplo, o distribuidor está desobrigado a entregar o preço, bem como o fornecedor de entregar a coisa prometida.

A resolução, além da eficácia liberatória, produz eficácia restituitória, ou seja, impõe aos contratantes restituir as prestações recebidas de modo a restaurar o estado anterior ao vínculo. Tudo se passa como se o contrato jamais tivesse existido ${ }^{222}$. A tutela jurídica, agora, é voltada a restabelecer a situação em que as partes se encontravam antes de concluir o negócio.

Precisamente por isso, surge a chamada relação de liquidação, na qual se equacionam os efeitos já produzidos pelo contrato. Seu objetivo é o de promover a reconstituição do status quo ante, ao menos do ponto de vista patrimonial. A resolução opera, portanto, efeitos ex tunc.

Os contratos de duração, entre os quais se encontra o contrato de distribuição, no entanto, seguem regra diversa. Aplica-se, por analogia, o art. 128 do Código Civil, para preservar as prestações executadas em conformidade com a natureza do negócio e as exigências da boa-fé objetiva ${ }^{223}$.

Nesta modalidade de negócio, a retroação limita-se em profundidade. A eficácia restituitória não se opera retroativamente, ou seja, não se estende às prestações já executadas. Ela opera a partir do momento em que se verificou a crise da relação contratual, ou seja, produz efeitos ex nunc ${ }^{224}$.

Se dois empresários firmaram um contrato de distribuição tendo por objeto a distribuição de combustíveis em 2010 e este foi corretamente adimplido até 2012 quando, então, sobreveio o descumprimento e, em 2013, foi dissolvida a relação contratual, os efeitos desta retroagirão ao ano de 2012. Não poderão atingir o período entre 2010 e 2012.

Por outro lado, caso o contrato continue sendo executado até 2013, apesar do descumprimento, a resolução produzirá seu efeito restituitório desde 2012. Tais efeitos

\footnotetext{
${ }^{222}$ Cf. ASsis, Araken de. Comentários ao Código Civil brasileiro, op. cit., 635 e PONTES DE MIRANDA, Francisco Cavalcanti. Tratado de Direito Privado, t. XXV, $3^{\mathrm{a}}$ ed., $2^{\mathrm{a}}$ reimp., São Paulo, RT, 1984, p. $307-$ 308.

${ }^{223}$ Cf. Assis, Araken de. Comentários ao Código Civil brasileiro, p. 639.

${ }^{224}$ Cf. Assis, Araken de. Comentários ao Código Civil brasileiro, op. cit., p. 640.
} 
atingirão, na verdade, o contrato até mesmo após a resolução e, para tanto, basta pensar que a devolução dos produtos cedidos em comodato ${ }^{225}$ se deu apenas em 2014.

Nos contratos de duração, portanto, o efeito restituitório não produz consequências nas prestações perfeitamente cumpridas, anteriores ao fato gerador da resolução. Não se pode, por outro lado, afastar das consequências da resolução os acontecimentos ocorridos após o descumprimento contratual ${ }^{226}$. Nada impede, porém, que as partes disciplinem a eficácia restituitória como mais lhes aprouver.

A parte que optar pela resolução da relação contratual deverá ainda ser ressarcida dos prejuízos sofridos com o inadimplemento de sua contraparte. Neste caso, o credor deverá ser indenizado por tudo o que perdeu com a celebração do contrato. A indenização cumulada à resolução procura, assim, colocar o prejudicado na situação em que se encontraria caso o contrato não houvesse sido celebrado.

Nas linhas acima, foi concebido um panorama das principais características da resolução. Sem prejuízo das regras anotadas, necessário atentar para o prescrito no art 474 do Código Civil, o qual prevê a existência de duas espécies de resolução, a qual será extrajudicial ou judicial, conforme as partes pactuem ou não uma cláusula resolutiva.

Convém, diante disto, examinar as particularidades de cada espécie.

\subsection{Resolução judicial}

A resolução, nos termos do art. 474 do Código Civil, pode ser judicial ou extrajudicial. Assim, na ausência de uma cláusula resolutiva expressa, a resolução depende da propositura de ação judicial, incidindo a disciplina prevista no art. 475 do Código Civil.

A resolução, como anotado acima, é consequência do inadimplemento definitivo. Poderá o credor optar por esta via, portanto, sempre que a prestação tornar-se irrealizável, seja em virtude de impossibilidade superveniente imputável ao devedor, seja devido à perda da utilidade da prestação ao credor.

Sua ocorrência, todavia, não é tão frequente quanto um exame rápido poderia sugerir, especialmente, por dois motivos. Primeiramente, a resolução tende a ocorrer em hipóteses mais restritas do que a realização coativa, posto que, nos contratos de duração,

\footnotetext{
${ }^{225}$ Vale anotar que os contratos de distribuição de combustíveis, geralmente, são acompanhados por cláusulas ou pacto acessório de comodato sobre alguns equipamentos, como as bombas de combustíveis. Por meio de tal estipulação, o distribuidor adquire o uso e fruição destes.

${ }^{226}$ ROPPO, Vicenzo. Il contratto, op. cit.,p.886
} 
entre os quais se enquadra o contrato de distribuição, a mora é mais frequente do que o inadimplemento definitivo.

O recurso à resolução da relação contratual encontra, em segundo, alguns limites que visam a evitar que o credor exerça seu direito de maneira abusiva. Para a resolução, o descumprimento não poderá apresentar escassa importância, tampouco poderá restar caracterizado o adimplemento substancial.

No contrato de distribuição, a resolução encontrará limites, sobretudo, na escassa importância. Este tipo negocial é composto por série de obrigações, as quais assumem relevância distinta na economia do contrato, o que explica que muitos dos descumprimentos ocorridos durante a vida do negócio apresentarão reduzida importância.

A procedência do pedido de resolução será negada, portanto, diante da presença de, ao menos, um destes limites, cabendo ao devedor provar a ocorrência destes. Para a correta compreensão de tais limites, cumpre nas próximas linhas conceituar o adimplemento substancial e o descumprimento de escassa importância, bem como examinar a relevância de tais figuras na resolução do contrato de distribuição.

\subsubsection{Adimplemento substancial}

O inadimplemento definitivo, como visto, pode ensejar a resolução da relação obrigacional. A resolução, no entanto, é impedida caso o interesse do credor, mesmo diante do inadimplemento definitivo, tenha sido satisfeito praticamente em sua integralidade. Trata-se do adimplemento substancial, figura originada da substancial performance do Common Law.

Nesta hipótese, apesar do descumprimento, há um adimplemento muito próximo ao resultado final pretendido pelo credor $^{227}$. O exemplo tradicionalmente empregado para explicar esta figura é aquele em que a parte adimpliu a grande maioria das parcelas de um contrato, conforme ilustra o aresto do Tribunal de Justiça do Estado de São Paulo que afastou a resolução diante do cumprimento de 169 prestações do total de $180^{228}$.

\footnotetext{
${ }^{227}$ Cf. FRADERA, Vera Maria Jacob de. O conceito de inadimplemento fundamental do contrato no artigo 25 da lei internacional sobre vendas, da Convenção de Viena de 1980. Revista da Faculdade de Direito da Universidade Federal do Rio Grande do Sul. Porto Alegre, vol. 11, p. 55-66, 1996. p. 59.

228 “Assim, considerado o adimplemento substancial da obrigação (94\% do valor do bem), dando-se o pagamento, ao que tudo indica, de 169 prestações do total de 180, como admite a autora, ora apela da, não é hipótese de

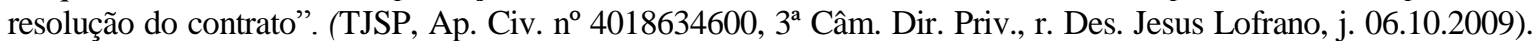
No mesmo sentido, cf. TJSP, AI n ${ }^{\circ}$ 2030663-44.2013.8.26.0000, 32 ${ }^{\mathrm{a}}$ Câm. Dir. Priv., r. Der. Luis Fernando Nishi, j. 31.10.2013; TJSP, Ap. Civ n ${ }^{\circ}$ 0081670-51.2009.8.26.0000, 27 a Câm. Dir. Priv., r. Des. Morais Pucci, j. 13.08.2013; TJSP, AI. no 0238119-32.2012.8.26.0000, 25 Câm. Dir. Priv., r. Des. Hugo Crepaldi, j. 28.11.2012;

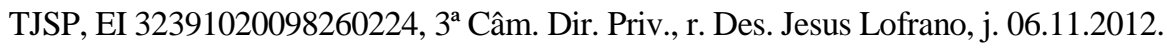


O adimplemento substancial veda, portanto, o uso abusivo do direito de resolução. Esta figura encontra fundamento na boa-fé objetiva, especialmente em sua função limitativa do exercício de direitos ${ }^{229}$, conforme secundado pelo Enunciado $\mathrm{n}^{\circ} 361$ da IV Jornada de Direito Civil ${ }^{230}$, que também recorre à função social para justificá-la.

Por fim, aproveita anotar, desde logo, que o adimplemento substancial não pode ser aplicado diante da cláusula resolutiva expressa. A presença de tal estipulação confere às partes a possibilidade de prever as hipóteses cuja ocorrência basta para por fim ao vínculo contratual. Não há que se discutir, assim, a importância do descumprimento, se as partes já o tiverem julgado suficiente para conduzir a extinção do vínculo.

Além do adimplemento substancial, a resolução restará impedida pela presença de um descumprimento de escassa importância. No inadimplemento do contrato de distribuição, cumpre destacar que a resolução será barrada, com maior frequência, pela ocorrência de inadimplementos de reduzida importância do que pela caracterização do adimplemento substancial.

Tal fato está intrinsecamente relacionado com a formação do contrato de distribuição por uma série de obrigações, as quais assumem distintos papéis no programa contratual. Neste cenário, convém examinar, nas próximas linhas, a gravidade do inadimplemento.

\subsubsection{Inadimplemento de escassa importância}

O direito à resolução nasce do inadimplemento definitivo das obrigações. Antes de iniciar o exame da gravidade do descumprimento, cumpre observar que, se de um lado, está correta a afirmação de que todo descumprimento é fonte de ressarcimento dos prejuízos por ele causados, de outro, é preciso notar que nem todo descumprimento, ainda que definitivo, é causa de resolução. Diante disto, faz-se necessário identificar qual descumprimento pode ensejar a dissolução da relação contratual.

Tal inadimplemento, primeiramente, deve ser irremediável. O exercício à resolução não nasce, deste modo, da simples mora no cumprimento do pactuado, mas tão somente do inadimplemento definitivo.

Não restam dúvidas, portanto, sobre a imprescindibilidade do inadimplemento definitivo. A doutrina e a jurisprudência, no entanto, controvertem-se acerca das

${ }^{229}$ Cf. FRADERA, Vera Maria Jacob de. O conceito de inadimplemento fundamental, op. cit., p. 59.

${ }^{230}$ Dispõe o enunciado 361 - Arts. 421, 422 e 475: O adimplemento substancial decorre dos princípios gerais contratuais, de modo a fazer preponderar a função social do contrato e o princípio da boa-fé objetiva, balizando a aplicação do art. 475. 
características deste descumprimento. Discute-se, basicamente, se basta o inadimplemento definitivo para fundamentar o pedido de resolução ou se este deverá ainda repercutir gravemente sobre a economia do negócio.

A orientação tradicional conclui que o direito à resolução resta limitado em face da presença de um descumprimento definitivo de escassa importância. Há um número ponderável de $\operatorname{arestos}^{231}$ e também alguns doutrinadores ${ }^{232}$ que decidiram, no entanto, privar o direito de resolução caso o descumprimento não apresente natureza grave.

A adoção de uma ou outra corrente, apesar da diferença sutil, produz relevantes consequências. Caso se entenda que o inadimplemento deve ser grave, há um novo requisito para a propositura da resolução, juntamente com inadimplemento definitivo. $\mathrm{Na}$ hipótese de bastar o inadimplemento definitivo para ensejar a resolução, por outro lado, a escassa importância assume papel de limitador de direito, cabendo ao devedor provar o descumprimento desimportante para afastar a incidência da resolução.

A solução para a controvérsia exige a consideração do art. 475 do Código Civil, cujo texto estabelece o fundamento para por fim ao vínculo contratual quando não pactuada uma cláusula resolutiva expressa.

Este dispositivo determina que a parte lesada pelo descumprimento pode pedir a resolução do contrato. Não resta dúvida, neste momento, que o texto refere-se ao inadimplemento definitivo, posto que a mora, por comportar emenda, não enseja o pedido de resolução. Não traz também o dispositivo qualquer outro critério e, em especial, nada dispõe sobre a necessidade do inadimplemento possuir natureza grave. De sua leitura, portanto, pode-se depreender o verdadeiro critério adotado pelo ordenamento brasileiro no que diz respeito à resolução.

O direito de resolução surge, assim, em razão de um inadimplemento definitivo. $O$ exercício de tal direito, no entanto, resta limitado em face da presença de um descumprimento desimportante. Não se trata, portanto, de pressuposto, mas de limite ao exercício do direito.

\footnotetext{
${ }^{231}$ Em julgamento sobre o tema, o Tribunal de Justiça do Estado de São Paulo asseverou que "A resolução do contrato somente pode ser a resposta a inadimplemento grave, que comprometa de modo substancial a prestação devida". (TJSP, Ap. Civ. no 398.166-4/0, 4ª Câm. Dir. Priv., r. Des. Francisco Loureiro, j. 02.04.2009). No mesmo sentido, Cf. TJSP, Ap. Civ. no 597.055-4/5-00, $3^{\text {a }}$ Câm. Dir. Priv., r. Des. Donegá Morandini, j. 06.10.2009; TJSP, Ap. Civ. no 0034849-57.2007.8.26.0000, $1^{\text {a }}$ Câm. Dir. Priv., r. Des. Alcides Leopoldo e Silva Júnior, j. 04.12.2012; TJSP, Ap. Civ. nº 0013175-98.2012.8.26.0565, $1^{\text {a }}$ Câm. Dir. Priv., r. Des. Paulo Eduardo Razuk, j. 20.08.2013.

${ }^{232}$ Neste sentido, Cf. Aguiar JUnior. Ruy Rosado. Comentários ao novo Código Civil, op. cit., p. 400; TePedino, Gustavo; BARbozA, Heloisa Helena; MORAES, Maria Celina Bodin de. Código Civil interpretado conforme a Constituição da República. Vol. II. Rio de Janeiro: Renovar, 2006, p. 21.
} 
A orientação adotada pelo direito brasileiro encontra inteira acolhida no direito italiano. $\mathrm{O}$ art. 1.455 do Código Civil peninsular é bastante claro ao prescrever que o contrato não pode ser resolvido se o inadimplemento de uma das partes tiver escassa importância, com relação ao interesse da outra. No mesmo sentido, a doutrina assevera que a escassa importância é elemento impeditivo da resolução ${ }^{233}$.

A dispensabilidade de um inadimplemento grave para ensejar a resolução demonstra, por outro lado, que o direito brasileiro afasta-se do prescrito na Convenção de Viena de 1980 sobre compra e venda de mercadorias, cujo art. 25 conceitua o inadimplemento fundamental (fundamental breach). De acordo com esta Convenção, a existência ou não do inadimplemento fundamental determina a manutenção ou a resolução do contrato 234 .

No direito brasileiro, basta, portanto, o inadimplemento definitivo para que o credor possa optar pela resolução do vínculo contratual. A resolução, por sua vez, será impedida e o vínculo mantido, caso o inadimplemento seja desimportante.

Esta regra objetiva manter a proporcionalidade do remédio resolutivo, posto que seria exagerado aplicar a resolução, uma medida drástica que põe fim ao contrato, diante de um ligeiro descumprimento do pactuado ${ }^{235}$.

A regra funciona, ainda, como uma salvaguarda do vínculo contratual, pois sem ela o contratante arrependido, poderia valer-se de qualquer descumprimento da contraparte para por fim ao negócio. Com ela, afigura-se pouco provável que o credor diante de um descumprimento desimportante opte pela resolução, a qual será julgada improcedente, no lugar de exigir a execução pelo equivalente.

A vedação à resolução em caso de inadimplemento de escassa importância encontra fundamento no art. 187 do Código Civil, de modo que a resolução não terá lugar se o descumprimento for tão desimportante que a finalidade econômico-social do contrato possa ser atingida quase que em sua integralidade.

É o caso, por exemplo, do inadimplemento definitivo da obrigação de prestar publicidade. Ainda que a prestação tenha se tornado para sempre irrealizável pela passagem do período para a qual se destinava, a finalidade do contrato de distribuição, via de regra, ainda é atingida.

\footnotetext{
${ }^{233}$ Cf. RopPo, Vicenzo. Il contratto, op. cit., p 900.

${ }^{234}$ Cf. FraderA, Vera Maria Jacob de. O conceito de inadimplemento fundamental, op. cit., p. 60-63.

${ }^{235}$ As razões para impedir a resolução diante do descumprimento de escassa importância são apontadas por Cf. RopPO, Vicenzo. Il contratto, op. cit., 899.
} 
Por todo o exposto, torna-se necessário perquirir o que é de escassa importância no descumprimento do contrato de distribuição. Segundo a doutrina, para tal definição, faz-se necessário o exame da função e do peso da prestação inadimplida na economia global do contrato $^{236}$.

No que diz respeito ao contrato de distribuição, o exame da função e do peso de cada prestação na economia do negócio foi realizado por meio da gradação finalística empreendida no primeiro capítulo deste trabalho. Em que pese a possibilidade de arranjos diversos na prática negocial, esta estrutura apresenta-se como um parâmetro para a solução dos conflitos.

Aproveita, em razão da importância que toma frente ao cabimento ou não da resolução, retomar a ilustração já exposta que organiza cada prestação de acordo com o papel e a relevância assumida na economia do negócio:

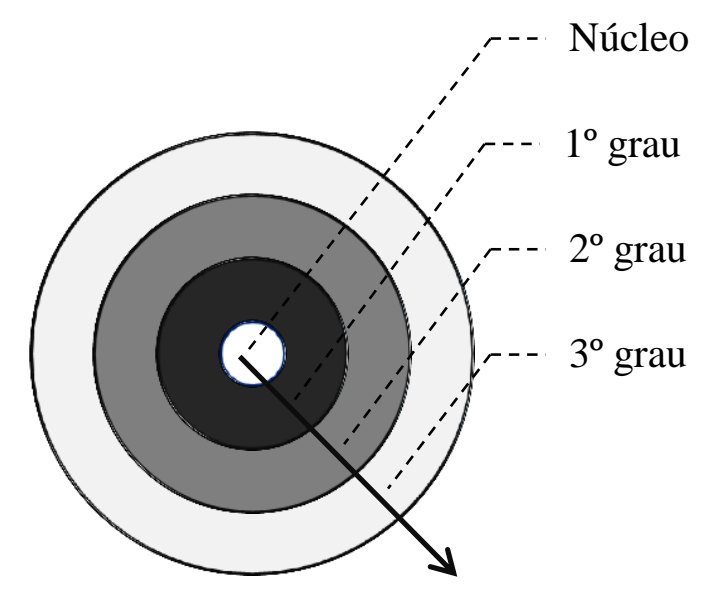

No centro dos círculos, situa-se o elemento categorial inderrogável do tipo negocial. A compra das mercadorias do fornecedor pelo distribuidor e a posterior destinação dessas à revenda torna-se, assim, o núcleo da representação. Nele, também se encontra o uso da marca, único elemento categorial derrogável. Encontram-se, a seguir, os elementos particulares de primeiro, segundo e terceiro grau, respectivamente.

Da leitura da figura, pode-se traçar uma tendência para o descumprimento do contrato de distribuição. Trata-se, como aproveita ressaltar, de uma orientação geral, pois, na prática, as partes podem pactuar de maneira diversa, ao valorar distintamente uma ou outra prestação ou ao estipular expressamente certa sanção para dado descumprimento.

${ }^{236}$ Cf. RopPO, Vicenzo. Il contratto, op. cit., 900. 
Em linhas gerais, pode-se concluir que a relevância do descumprimento para a economia global do contrato tende a diminuir no sentido do núcleo para as bordas, conforme indicação da seta. Assim, quanto mais próximo do núcleo recair o descumprimento definitivo, mais relevante ele se torna; por outro lado, quanto mais distante, mais desimportante.

Vale recorrer ao exemplo do descumprimento da obrigação do fornecedor de entregar as mercadorias adquiridas pelo distribuidor. Tal descumprimento, na maioria da vezes, irá caracterizar a mora, pois as mercadorias ainda serão, geralmente, úteis ao distribuidor, o qual poderá revendê-las no mercado após o recebimento. Na hipótese, entretanto, do descumprimento prolongar-se ou afigurar-se tão recorrente que prejudique a consecução dos fins do contrato, seja por causar perdas irreversíveis de participação no mercado, seja por sua retomada demandar custos inexigíveis do contratante fiel, estará caracterizado o inadimplemento definitivo e, deste modo, poderá o distribuidor resolver o contrato.

O inadimplemento de uma obrigação de $3^{\circ}$ grau, por sua vez, tende a caracterizar-se como desimportante frente à economia global do contrato. Basta pensar, por exemplo, na obrigação do distribuidor de prestar ao fornecedor informações sobre o mercado de tempos em tempos. Ainda que o distribuidor não o faça no prazo estipulado ou exatamente conforme o pactuado, a finalidade do contrato é atingida praticamente em sua integralidade e a resolução não se apresenta, então, como o remédio mais adequado.

Necessário notar, todavia, que se o descumprimento de uma destas prestações afigura-se de escassa importância, o mesmo não ocorrerá caso sejam descumpridas várias destas prestações. Quando descumpridas em conjunto, alteram-se a função e o peso de tais inadimplementos, impossibilitando a consecução da finalidade do negócio ${ }^{237}$. $\mathrm{O}$ direito à resolução poderá nascer, assim, do descumprimento de um conjunto de obrigações compreendidas nos círculos mais distantes.

Além da valoração da função e do peso da prestação inadimplida para a economia global do contrato, a definição da escassa importância requer ainda a consideração da utilidade da prestação descumprida, fundada no interesse do contratante fiel prejudicado pelo inadimplemento ${ }^{238}$.

Assim, um inadimplemento que segundo o primeiro critério ensejaria resolução, pode tornar-se desimportante frente a utilidade da prestação no negócio concretamente

${ }_{237}^{237}$ Cf. RoPPO, Vicenzo. Il contratto, op. cit., 900.

${ }^{238}$ Cf. RopPO, Vicenzo. Il contratto, op. cit., 900. 
considerado. É o caso, por exemplo, do inadimplemento definitivo na entrega de mercadorias destinadas a um período específico (por exemplo, a Copa do Mundo). Nesta hipótese, ainda que o cumprimento de tal prestação seja inútil, o distribuidor pode considerar tal inadimplemento desimportante no programa contratual global e, consequentemente, optar pela execução pelo equivalente, por meio da qual preserva-se a relação contratual e obtém-se o ressarcimento dos prejuízos havidos.

No que diz respeito aos requisitos e limites da resolução, faz-se oportuno examinar, por fim, a afirmação de que a quebra da confiança poderia ensejar a resolução dos $\operatorname{contratos}^{239}$, fato este que restaria acentuado na categoria dos contratos de colaboração, na qual se filia o contrato de distribuição. Tal afirmação exige, porém, reflexões.

A resolução não surge pela quebra subjetiva da confiança. A alteração, por exemplo, de partido político por um dos contratantes não pode ensejar a resolução do contrato de distribuição, por não implicar a violação de qualquer cláusula pactuada.

O direito de resolução resulta, precisamente, do inadimplemento irreversível dos deveres emanados do vínculo, exceto se tal descumprimento for de tal maneira desimportante que não afete a finalidade do contrato ou se o interesse do credor já tenha sido satisfeito praticamente em sua integralidade. Nestas últimas hipóteses, ao contratante inocente resta apenas exigir a execução pelo equivalente, cumulada com a respectiva indenização.

Nem sempre, porém, será necessário discutir qual descumprimento enseja a resolução da relação contratual. As partes podem acordar, desde o momento da formação do contrato, as situações que conduzem à resolução. Trata-se, em verdade, de estipulação bastante corriqueira nos contratos de distribuição. Isto se dá por meio da cláusula resolutiva expressa, tema que as próximas linhas dedicam-se a analisar.

\subsection{Cláusula resolutiva}

A cláusula resolutiva expressa é uma estipulação que possibilita ao contratante fiel por fim à relação contratual diante do inadimplemento de sua contraparte. Seus efeitos operam de pleno direito no momento em que a parte, que manejou a prerrogativa contida na cláusula, dá notícia ao contratante inadimplente da extinção do vínculo.

\footnotetext{
${ }^{239}$ Cf. SILVA, Jorge Cesa Ferreira da. A boa-fé e a violação, op. cit., p. 252-255.
} 
A comunicação da resolução não se sujeita a qualquer solenidade, embora a forma escrita seja preferível por razão probatória ${ }^{240}$. A inclusão desta cláusula em um contrato atende, essencialmente, a duas funções, conforme cumpre examinar.

Sua inclusão em um contrato afasta, de um lado, a necessidade de se recorrer ao Poder Judiciário para a extinção da relação obrigacional, pois a superveniência da hipótese prevista na referida cláusula é o suficiente para dissolver o vínculo contratual.

Esta é a orientação adotada pelo art. 474 do Código Civil, cujo texto de maneira clara dispõe que os efeitos da cláusula resolutiva expressa operam de pleno direito. Tratase de entendimento amplamente reconhecido pela doutrina ${ }^{241}$ e corroborado pelo enunciado 436 aprovado na V Jornada de Direito Civil ${ }^{242}$.

A cláusula resolutiva expressa presta-se, de outro lado, para que as partes definam, desde a formação do negócio, a importância concreta de cada obrigação contraída, ao autorizar que a parte lesada tenha o direito de por fim à relação, caso a obrigação prevista seja descumprida. A cláusula resolutiva, por outras palavras, permite aos contratantes valorar as prestações cujo descumprimento é o bastante para extinguir a relação jurídica obrigacional.

Diante da cláusula resolutiva, não há espaço, portanto, para se discutir judicialmente a importância do inadimplemento ${ }^{243}$, em que pesem argumentos $\operatorname{contrários}^{244}$. É perfeitamente possível, inclusive, que as partes pactuem que uma obrigação, geralmente de pequena relevância, seja reputada como bastante para extinguir a relação obrigacional.

\footnotetext{
${ }^{240}$ Cf. CARvalho SAntos, João Manuel. Código Civil brasileiro interpretado. Vol. III. 10 a ed., Rio de Janeiro: Freitas Bastos, s/d. p. 76.

${ }^{241}$ Cf. Assis, Araken de. Comentários ao Código Civil brasileiro, op. cit., p. 582. No mesmo sentido, ZANETTI, Cristiano de Sousa. A cláusula resolutiva expressa na lei e nos tribunais: o caso do termo de ocupação. In LOTUFO, Renan; NANNI, Giovanni Ettore; MARTINS, Fernando Rodrigues (coord.). Temas relevantes do direito civil contemporâneo: reflexões sobre os 10 anos do Código Civil. São Paulo: Atlas, 2012. p. 356.

${ }^{242}$ Trata-se do Enunciado no 436 aprovado em 2011, cujo texto dispõe: “Art. 474. A cláusula resolutiva expressa produz efeitos extintivos independentemente de pronunciamento judicial".

${ }^{243}$ Cf. Assis, Araken de. Comentários ao Código Civil brasileiro, op. cit., p. 584 e 589; e ZANETTI, Cristiano de Sousa. Cláusula resolutiva expressa, op. cit., p. 357.

${ }^{244}$ De acordo esta linha doutrinária, o princípio da boa-fé impede que as partes prevejam a extinção do vínculo contratual, caso seja descumprida obrigação de reduzida importância ou haja adimplemento substancial. Nesse sentido, cf. TEPEDINO, Gustavo; BARBOZA, Heloisa Helena; MORAES, Maria Celina Bodin de. Código Civil interpretado, Vol. II, op. cit., p. 119 e AGUIAR JÚNIOR, Ruy Rosado. Comentários ao novo Código Civil, op. cit., pp. 388-389, 400-401 e 412-413.
} 
As partes, com fundamento na autonomia da vontade, podem, deste modo, decidir sobre as causas passíveis de conduzir à extinção do vínculo contratual ${ }^{245}$. De nada importa que, sob o ponto de vista de terceiro, o incumprimento possa ser considerado de maior ou menor importância, pois o critério adotado pelas partes é decisivo.

A cláusula resolutiva, ao permitir a extinção do vínculo obrigacional sem a necessidade de recurso ao Poder Judiciário, evidencia, portanto, a ampla margem decisória conferida aos contratantes pelo ordenamento jurídico.

A orientação adotada pelo direito brasileiro encontra inteira acolhida no Draft Common Frame of Reference, o qual reconhece às partes a prerrogativa de decidir como se dará o final da respectiva relação contratual. Trata-se do art. III. - 1:109, cujo texto dispõe que as partes são livres para decidir as causas que poderão conduzir à extinção do vínculo jurídico que as une.

Tal orientação é adotada também pelo art. 1.456 do Código Civil italiano. De acordo com a doutrina peninsular ${ }^{246}$, é vedado ao Poder Judiciário discutir a importância do descumprimento, se as partes já o tiverem julgado suficiente para conduzir a extinção do vínculo.

Cumpre ressaltar, assim, que diante da estipulação de uma cláusula resolutiva expressa em um contrato de distribuição, não se pode aplicar de maneira irrefletida a gradação finalística dos elementos desenvolvida no primeiro capítulo deste trabalho.

Isso porque dado elemento pode ser fundamental para aqueles contratantes, embora, geralmente, encontre-se qualificado entre os elementos particulares de $2^{\circ}$ ou $3^{\circ}$ grau. Por outras palavras, um elemento tradicionalmente qualificado como particular pode, em concreto, ser reputado de importância decisiva, a fim de que sua ocorrência baste à extinção da relação jurídica.

Vale pensar, sempre à titulo ilustrativo, em um contrato de distribuição que tenha por objeto uma nova linha de produtos destinada a segmento de mercado antes inexplorado por aquela rede distributiva. É o caso, por exemplo, da introdução no mercado de divisão

\footnotetext{
${ }^{245}$ Segundo a doutrina, a "admissão da cláusula resolutiva expressa responde a uma exigência lógica própria às chamadas 'sociedades de direito privado', caracterizadas por reconhecer a liberdade dos cidadãos que nelas vivem". (Cf. ZANETTI, Cristiano de Sousa. A cláusula resolutiva expressa, op. cit., p. 357).

${ }^{246}$ Cf. BIANCA, C. Massimo, Diritto civile: la responsabilità, op. cit., p. 315-316; Gallo, Paolo. Trattado del contratto: I rimedi, la fidúcia, l'apparenza. Tomo III. Torino: UTET, 2010. p. 2.161; NANNI, Luca; CostanZA, Maria; CARNeVAli, Ugo. Risoluzione per inadempimento. Tomo I, parte 2. Bologna: Zanichelli, 2007. pp. 45 e 59-62; RoPPO, Vicenzo. Il contratto, op. cit., p. 905; SACCO, Rodolfo; DE NovA, Giorgio. Il contratto. Tomo II. $3^{\mathrm{a}}$ ed. Torino: UTET, 2004. p. 657; e SICCHIERO, Gianluca. La risoluzione per inadempimento. Commentario Artt. 1453-1459. Milano: Giuffrè, 2007. pp. 594-598. Em sentido contrário, cf. MonGILLO, Roberta. Inadempimento e risoluzione di diritto. Quaderni della Rassegna di diritto civile direta da Pietro Perlingieri. Napoli: Edizioni Scientifiche Italiene, 2012. p. 210-217.
} 
de luxo e desempenho de determinada montadora de veículos, a qual atuava, até então, apenas no segmento de populares e médios.

Nesta hipótese, a realização de publicidade e a observância de certo padrão de atendimento pelo distribuidor tornam-se fundamentais para que o contrato atinja seu fim e, diante disso, as partes elencam a inobservância de tais prestações entre as hipóteses da cláusula resolutiva. O descumprimento de qualquer uma destas obrigações basta, portanto, para a extinção da relação obrigacional.

Na prática brasileira, entretanto, afigura-se bastante comum a presença de cláusulas resolutivas genéricas, cujo texto determina que o descumprimento de qualquer das obrigações contratualmente previstas poderá acarretar a extinção da relação contratual.

Estas cláusulas são interpretadas pela doutrina como meras cláusulas de estilo, cujo conteúdo, predominantemente, visa a reforçar a sujeição das partes à integral observância do avençado ${ }^{247}$. Do seu conteúdo não se pode inferir que o descumprimento de qualquer estipulação levará a resolução da relação contratual.

A cláusula resolutiva para produzir seus efeitos típicos, portanto, deve trazer uma indicação pormenorizada das hipóteses passíveis de conduzir a resolução da relação contratual. $\mathrm{Na}$ ausência destas características, o contratante prejudicado pelo inadimplemento de sua contraparte deve recorrer à resolução junto a órgão dotado de poder jurisdicional.

$\mathrm{Na}$ resolução judicial, por sua vez, há espaço para se discutir a importância do inadimplemento definitivo. Neste caso, diferentemente, do que ocorre diante da cláusula resolutiva expressa pela qual as partes valoram previamente a relevância de cada obrigação, o contratante inocente pode afastar a resolução da relação contratual, caso comprove o adimplemento substancial ou ter incorrido em um descumprimento tão desimportante que, a despeito de sua falta, a finalidade do contrato é atingida praticamente em sua integralidade.

Na ausência de cláusula resolutiva, portanto, o inadimplemento definitivo das obrigações não leva a resolução de pleno direito do vínculo contratual. A resolução pode, até mesmo, ser afastada, caso caracterizados os dois mencionados limites. Nestas duas hipóteses, ao contratante inocente resta valer-se apenas da execução pelo equivalente e as respectivas perdas e danos.

${ }^{247}$ Cf. Aguiar Júnior, Ruy Rosado. Comentários ao novo Código Civil, op. cit., p. 400. 
Por todo o exposto neste item, foi possível depreender que a resolução e a execução pelo equivalente são figuras complementares, de modo que o contratante prejudicado pelo inadimplemento de sua contraparte pode optar por uma ou outra figura, conforme as características concretamente apresentadas pelo descumprimento.

Não restam dúvidas, por outro lado, que a estipulação de uma cláusula resolutiva expressa altera toda a dinâmica da resolução. Destinada a secundar os interesses das partes, a disciplina contratual lhes confere ampla margem decisória para que possam decidir a respeito das causas passíveis de conduzir à extinção do respectivo vínculo jurídico, independentemente de pronunciamento de órgão dotado de poder jurisdicional que reconheça a extinção da relação contratual.

Concluído, pois, o exame da resolução, convém investigar o efeito geral e típico do descumprimento das obrigações, qual seja o ressarcimento dos prejuízos havidos pelo contratante fiel em virtude do descumprimento de sua contraparte.

\section{Indenização}

O efeito geral e típico do inadimplemento das obrigações, nos termos do art. 389 do diploma civil, é a responsabilidade pelo pagamento de perdas e danos. A obrigação, no entanto, só terá lugar se o contratante fiel sofrer algum prejuízo em virtude do descumprimento.

Na hipótese de existir um dano, como geralmente sucede, o dever de reparação, conforme o art. 402 do Código Civil, abrange os danos emergentes e os lucros cessantes, ou seja, tudo aquilo que se perdeu e que se deixou de lucrar com o inadimplemento da contraparte.

Vale, em adição, anotar que as partes podem previamente estimar e determinar o valor das perdas e danos devidas ao credor, dado o inadimplemento definitivo ou a mora ou ainda a inexecução de alguma cláusula especial do negócio. Tal estipulação é chamada de cláusula penal e afigura-se extremamente útil, sobretudo, para o ressarcimento do descumprimento de obrigações de fazer, posto que dispensa a necessidade de se apurar o valor devido por meio de liquidação judicial.

Quando não pactuada uma cláusula penal, a indenização será fixada de acordo com os critérios indicados no citado art. 402, ou seja, danos emergentes e lucros cessantes. A primeira figura é a perda ocasionada no patrimônio do contratante inocente em razão do 
descumprimento de sua contraparte. O dano emergente abrange, mais precisamente, não apenas uma diminuição do ativo, mas também qualquer aumento do passivo ${ }^{248}$.

Pode-se pensar, a título ilustrativo, na aquisição de mercadoria deteriorada que, além de imprestável, causa danos ao estoque que se encontra no depósito do distribuidor de gêneros alimentícios.

O lucro cessante, por sua vez, representa aquilo que o credor deixou de lucrar com o inadimplemento de sua contraparte. Trata-se, por outras palavras, dos ganhos que o credor ficou privado em virtude do inadimplemento de sua contraparte.

Cumpre anotar que os lucros cessantes, conforme preceitua o art. 403 do Código Civil pátrio, só incluem os prejuízos efetivos. Para a exata compreensão, vale tomar como exemplo o caso de um distribuidor que, mensalmente, adquire 400 caixas de dada mercadoria do fornecedor. Em determinado mês, o fornecedor, por causa a ele imputável, não entrega na data pactuada os produtos, causando prejuízos ao distribuidor, o qual vê seus clientes procurarem seus concorrentes para adquirir os produtos que ele não possui.

No cálculo da indenização devida a este distribuidor, a composição dos lucros cessantes não deve considerar as expectativas de lucros. Ele está adstrito aos dados objetivos. Os lucros cessantes, no caso narrado, serão quantificados, portanto, com base nas situações anteriores, nas quais houve o adimplemento da prestação.

A indenização, composta pelos danos emergentes e pelos lucros cessantes, estará presente sempre que houver um prejuízo decorrente do inadimplemento obrigacional. Será, assim, cumulada às demais consequências, quais sejam a realização coativa da prestação, a execução pelo equivalente ou a resolução.

Nestas situações nem sempre, porém, a indenização visa idêntica reparação. Ao prejudicado pelo descumprimento é dado exigir, em algumas hipóteses, que a indenização recoloque o contratante inocente na posição que se encontraria caso o contrato tivesse sido fielmente cumprido. Noutras, a indenização procura colocar o lesado na situação em que estaria se não tivesse celebrado o contrato.

A indenização, deste modo, pode se referir, respectivamente, ao interesse contratual positivo, também chamado de interesse no cumprimento, ou ao interesse contratual negativo, conhecido ainda como interesse na confiança ${ }^{249}$.

\footnotetext{
${ }^{248}$ Cf. AlviM, Agostinho. Da inexecução das obrigações, op. cit., p. 174.

${ }^{249}$ Cf. PINTO, Paulo Mota. Interesse contratual negativo e interesse contratual positivo. Vol. I. Coimbra: Editora Coimbra, 2008. p. 6.
} 
O recurso a tal classificação, apesar da codificação civil não a empregar expressamente, afigura-se extremamente útil para delimitar o alcance da obrigação de indenizar frente a cada consequência com que será cumulada.

No trabalho ora desenvolvido, esta divisão presta-se, essencialmente, a distinguir a indenização cumulada à resolução daquela apresentada nas demais hipóteses, uma vez que o credor que resolve o contrato devido ao inadimplemento do devedor fica impossibilitado de reclamar a reparação dos danos correspondentes ao interesse positivo.

Pela importância assumida por tal divisão como medida para a indenização, cumpre examinar o alcance destas figuras na reparação dos danos havidos com o inadimplemento do contrato de distribuição. É do que se passa a cuidar.

\subsection{Indenização do interesse positivo}

A indenização do interesse positivo destina-se a colocar o lesado na situação em que se encontraria caso o contrato houvesse sido cumprido exatamente conforme o pactuado.

Abrange, portanto, não apenas o valor objetivo da prestação, quando a prestação não mais pode ser cumprida, mas também a cobertura de todos os prejuízos provenientes da inexecução, de modo a colocar o credor na situação patrimonial em que ele estaria com o exato adimplemento ${ }^{250}$ do contrato.

No contrato de distribuição, por exemplo, o distribuidor em face da mora do fornecedor em entregar mercadorias pode exigir o lucro que auferiria mediante o cumprimento do pactuado. Também lhe é dado obter o ressarcimento de outros prejuízos decorrentes da mora, como o ressarcimento dos custos incorridos para comprar mercadorias a um preço superior de outro distribuidor integrante da rede do fornecedor para atender à demanda do mercado, em razão do atraso na entrega pelo fornecedor.

No contrato de distribuição, tutelam o interesse contratual positivo a indenização cumulada à execução específica e à execução pelo equivalente, inclusive, aquela resultante do inadimplemento definitivo que não comporta resolução, em virtude da presença de adimplemento substancial ou inadimplemento desimportante.

\footnotetext{
${ }^{250}$ Cf. MARTins-CostA, Judith. Comentários ao novo Código, op. cit., p. 480-481; CostA, Mário Júlio de Almeida. Direito das obrigações, op. cit., p. 598; PINTO, Paulo Mota. Interesse contratual negativo e interesse contratual positivo. Vol. II. Coimbra: Editora Coimbra, 2008. p. 871; e ANTUNES VARELA, João de Matos. Das obrigações em geral, Vol. II, op. cit., p. 93.
} 
Tutelam o interesse positivo, portanto, todas as demandas de cumprimento, seja aquela satisfeita através da realização da própria prestação até então inadimplida seja por meio de uma prestação equivalente de natureza pecuniária, que visa a substituir aquela descumprida.

\subsection{Indenização do interesse negativo}

A indenização resultante da tutela do interesse negativo objetiva colocar o contratante lesado pelo inadimplemento alheio na posição que se encontraria caso o contrato não tivesse sido celebrado, isto é, caso não houvesse contado com a eficácia do negócio jurídico ora descumprido ${ }^{251}$.

Os prejuízos a ressarcir são aqueles em que a parte incorreu por ter confiado na execução do contrato. Serão ressarcidas, de um lado, todas as despesas tornadas inúteis em face do descumprimento, como, por exemplo, aquelas incorridas pelo fornecedor para o transporte das mercadorias que, ao final, não foram adquiridas pelo distribuidor. Nomeadamente, as despesas necessárias à execução do contrato estão compreendidas no interesse negativo e, portanto, devem ser ressarcidas pela parte culpada pelo inadimplemento absoluto ${ }^{252}$.

No contrato de distribuição, são outros exemplos as despesas havidas para adequação aos padrões exigidos pelo fornecedor, para a manutenção das mercadorias em estoque, ou ainda os custos havidos para confecção de material publicitário inutilizado em virtude da resolução do negócio.

O contratante lesado terá também direito ao ressarcimento por tudo o que perdeu ou deixou de ganhar por acreditar na execução do contrato. Para melhor compreensão, considere, como exemplo, o fornecedor que apenas por seguir as informações sobre o mercado dadas pelo distribuidor e que, ao final, se revelaram falsas, teve de abrir mão de outro negócio que lhe teria proporcionado comprovadamente lucro de certo montante.

A indenização pelo interesse contratual negativo é encontrada no ressarcimento acrescido ao direito de resolução e tem em mira reconduzir a parte à situação que se encontrava antes de celebrar o negócio jurídico. Na verdade, optando o contratante pela

\footnotetext{
${ }^{251}$ Cf. Costa, Mário Júlio de Almeida. Direito das obrigações, op. cit., p. 1.044-1.045.

${ }^{252}$ Cf. Assis, Araken de. Comentários ao Código Civil brasileiro, op. cit., p. 646.
} 
resolução seria um tanto quanto contraditório poder requerer, concomitante, a indenização pelo não cumprimento ${ }^{253}$.

A indenização que se cumula com a resolução, portanto, visa a tutelar apenas o interesse contratual negativo ${ }^{254}$. Com ela, o contratante pretende, primeiramente, exonerarse da obrigação por ele assumida e ainda a reposição do seu patrimônio como se nunca houvesse celebrado o contrato.

Por todo o aqui exposto, foi possível depreender que a indenização decorrente do inadimplemento obrigacional visa a reparar duas modalidades de interesses. Trata-se do interesse contratual positivo e do interesse contratual negativo. No contrato de distribuição, as hipóteses de indenização mais recorrentes tutelam o interesse positivo e procuram colocar o contratante inocente na posição que se encontraria com o cumprimento exato do pactuado. A indenização pelo interesse negativo, por sua vez, resta presente na indenização cumulada com a resolução.

Concluído, pois, o exame das principais consequências do inadimplemento ocorrido no âmbito do contrato de distribuição, cumpre, por fim, analisar a exceção do contrato do não cumprido.

\section{Exceção do contrato não cumprido}

A exceção do contrato não cumprido, nos termos do art. 476 do Código Civil, é uma medida que suspende temporariamente a obrigação de adimplir enquanto o outro contratante não executar sua prestação. Tal figura aproveita para evitar, primeiramente, que o referido contratante preste sem antes ter recebido o que lhe é devido. Em adição, previne que o outro contratante peça a resolução do contrato por inadimplemento.

Para a exata compreensão desta figura, vale recorrer ao exemplo do contrato de locação. Neste contrato, o locatário pode opor tal exceção e, com isso, suspender a execução de sua obrigação de pagar o aluguel, caso o locador ainda não lhe tenha entregue a coisa, cuja posse contratara.

\footnotetext{
${ }^{253}$ Cf. Costa, Mário Júlio de Almeida. Direito das obrigações, op. cit., p. 1.045.

${ }^{254}$ Neste sentido, cf. MARTins-COSTA, Judith. Comentários ao novo Código, op. cit., p. 489-491; ASSIS, Araken de. Dano positivo e dano negativo na dissolução do contrato. Revista do Advogado, São Paulo, v. 44, p. 20-23, 1994; CostA, Mário Júlio de Almeida. Direito das obrigações, op. cit., p. 1044-1045; ANTUNES VARELA, João de Matos. Das obrigações em geral, Vol. II, op. cit., p. 106-112. Cumpre ressaltar, porém, que se manifesta contra tal orientação Paulo Mota Pinto, o qual defende que, diante da resolução contratual fundada no inadimplemento obrigacional, pode o contratante inocente optar pela indenização fundada no interesse positivo ou no negativo. (Cf. PINTO, Paulo Mota. Interesse contratual negativo e interesse contratual positivo. Vol. II. Coimbra: Editora Coimbra, 2008. p. 1.639 e ss e 1.699.
} 
O âmbito operativo da exceção do contrato não cumprido mira, deste modo, negócios jurídicos em que uma parte assume o dever de prestar para que a outra lhe contrapreste $^{255}$. Nestes casos, a prestação é a razão de ser da contraprestação e vice versa. O manejo da exceção do contrato não cumprido pressupõe, assim, que as prestações, além de interdependentes, sejam simultâneas.

Diante de tal pressupostos, a exceção do contrato não cumprido será ferramenta pouco manejada diante do descumprimento do contrato de distribuição. Como tal contrato é composto por uma série de obrigação com peso e momento de execução diverso, dificilmente o inadimplemento irá afetar prestações interdependentes e simultâneas.

A exceção do contrato não cumprido é assim é última consequência prevista no ordenamento jurídico pátrio em face do inadimplemento obrigacional.

\section{Conclusões preliminares e caminhos do estudo}

O presente capítulo dedicou-se a aclarar as consequências previstas pelo ordenamento para o inadimplemento das obrigações. A partir de um estudo aplicado ao contrato de distribuição, o capítulo pretendeu, mais precisamente, realizar uma análise sistemática do tema ao combinar as modalidades de inadimplemento - mora e inadimplemento definitivo - às respectivas consequências.

O capítulo ocupou-se, assim, em identificar as hipóteses de cabimento, bem como as principais características, da realização coativa da prestação, da execução pelo equivalente, da resolução e das perdas e danos. O trabalho, por fim, empenhou-se em esclarecer porque no contrato de distribuição a exceção do contrato não cumprido, mais uma hipótese prevista para o descumprimento das obrigações no direito brasileiro, apresenta rara aplicação.

Por todo o exposto, pode-se depreender que a realização coativa da prestação, através da ação de cumprimento ou da execução específica, somente pode ser manejada diante da mora. Nestes casos, embora a prestação não tenha sido voluntariamente executada no tempo, no lugar ou de acordo com a maneira pactuada, a prestação ainda é possível e útil ao contratante fiel e, diante disso, o ordenamento lhe assegura o direito de exigir o cumprimento.

${ }^{255}$ Cf. Assis, Araken de. Comentários ao Código Civil brasileiro, op. cit., p. 665. 
O credor, cumulativamente à prestação, tem direito também ao ressarcimento dos danos sofridos com a mora no cumprimento. Tal indenização pretende colocar o contratante lesado pela mora na posição que se encontraria caso o contrato houvesse sido cumprido exatamente conforme o pactuado. Tutela, portanto, o interesse contratual positivo.

A realização coativa da prestação torna-se impraticável diante do inadimplemento definitivo, e, portanto, irremediável. Para as hipóteses de inadimplemento definitivo, o regramento pátrio prevê duas soluções.

Trata-se, primeiramente, da execução pelo equivalente. Neste caso, como a prestação tornou-se irrealizável, esta será substituída por um equivalente de natureza pecuniária. Acrescida à prestação substitutiva, estará presente o ressarcimento pelos danos sofridos pelo não cumprimento da prestação tal qual pactuado. Esta indenização também tutela, portanto, o interesse contratual positivo.

A segunda solução prevista para o inadimplemento definitivo é a resolução, a qual poderá ser judicial ou extrajudicial, conforme as partes tenham ou não pactuado uma cláusula resolutiva expressa.

No que diz respeito ao pedido de resolução judicial, este será julgado improcedente caso reste caracterizado o adimplemento substancial ou o inadimplemento apresente escassa importância. Para a apuração da importância de cada obrigação que compõe o contrato de distribuição, tornou-se fundamental o recurso a hierarquia representada pelo modelo de círculos concêntricos. Este tipo negocial tende, portanto, a apresentar escassa importância, frente a economia global do contrato, o descumprimento das obrigações situadas nos círculos mais externos. O descumprimento, por sua vez, ganha em relevância com a aproximação gradativa do núcleo da representação gráfica.

Nem sempre, todavia, haverá espaço para a discussão da gravidade do descumprimento ou da presença do adimplemento substancial. Quando as partes estipulam a cláusula resolutiva expressa, ocorrida a hipótese ali elencada, a resolução opera de pleno direito.

O contratante fiel, em uma ou outra modalidade de resolução, terá direito ao ressarcimento pelo o que perdeu ou deixou de ganhar por acreditar na execução do contrato. Tal indenização, por outras palavras, visa a reparar o prejuízo que o contratante lesado sofreu por ter celebrado o negócio. A indenização resultante da resolução, portanto, é a única a tutelar o interesse contratual negativo. 
Vale recorrer, para sistematizar as conclusões até o momento apresentadas, a uma ilustração:

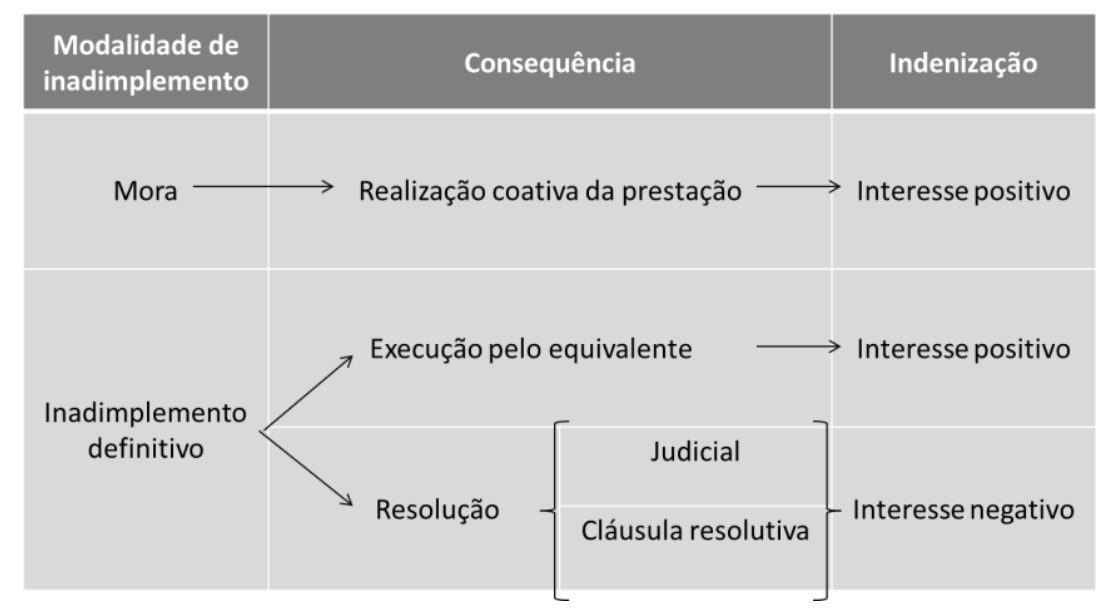

Pode-se, por outras palavras, concluir que o ordenamento jurídico reconhece ao contratante fiel a prerrogativa de requerer o cumprimento ou a resolução do contrato, observados os respectivos pressupostos. A resolução é remédio que põe fim a relação jurídica obrigacional. A demanda de cumprimento, por sua vez, mantém o vínculo entre as partes e se satisfaz mediante a realização da prestação ou através de uma prestação equivalente de natureza pecuniária, que visa a substituir a prestação que tenha se tornado para sempre impossível ou inútil.

A escolha entre uma ou outra via depende das circunstâncias do caso concreto. É possível depreender, todavia, alguns critérios. A possibilidade e a utilidade da prestação inadimplida, ou seja, o caráter definitivo ou não do descumprimento, a caracterização do adimplemento substancial ou ainda a presença de descumprimento desimportante para a economia global do negócio são aspectos essenciais para fundamentar a opção do contratante inocente.

Vale destacar, por fim, que requerido o adimplemento ou a resolução, o contratante lesado pelo descumprimento tem direito, em todo caso, ao ressarcimento dos danos havidos, nos termos do art. 389 do Código Civil.

Aclaradas as características, bem como definido o cabimento de cada consequência prevista no ordenamento pátrio para o inadimplemento das obrigações, cumpre no capítulo que segue examinar como tais consequências serão manejadas diante do inadimplemento de ambos os contratantes. 
O próximo capítulo, deste modo, pretende realizar um exame concatenado dos temas anteriormente examinados, com vistas a determinar o tratamento das hipóteses de inadimplemento recíproco do contrato de distribuição, frente à ausência de regras próprias no Código Civil pátrio. Todo o percurso investigativo até o momento empreendido culmina, portanto, na construção a seguir. 


\section{CAPÍTULO 2 - AS REPERCUSSÕES DO INADIMPLEMENTO RECÍPROCO}

\section{Introdução}

Para satisfazer os propósitos do presente esforço teórico, faz-se oportuno, neste momento, ultrapassar o inadimplemento singular e observar que, na prática comercial, tornam-se cada vez mais corriqueiras situações em que ambos os contratantes não cumprem exatamente suas obrigações.

No contrato de distribuição, por se tratar de negócio destinado a ter longa duração e que requer a atuação colaborativa das partes, os conflitos decorrentes da inexecução recíproca das obrigações contraídas tornam-se ainda mais frequentes.

A expressão inadimplemento recíproco, conforme já conceituado no segundo capítulo da primeira parte deste trabalho ${ }^{256}$, é empregada para indicar situações em que ambas as partes deixam de efetuar, nos termos adequados, uma prestação cujo cumprimento corria por sua própria conta.

O inadimplemento recíproco pode recair, primeiramente, sobre prestações interdependentes e simultâneas. Neste caso, o contratante insatisfeito pode valer-se da exceção do contrato não cumprido. É possível ainda, sobretudo em negócios em que há multiplicidade de prestações e contraprestações, tal qual ocorre no contrato de distribuição, que a inexecução não afete prestações interdependentes e simultâneas.

Nesta última hipótese, ambas as partes descumprem prestações pactuadas, mas nenhuma pode legitimamente valer-se da exceção. Verifica-se situação semelhante a dois descumprimentos unilaterais, uma vez que cada inadimplemento deve ser caracterizado de maneira autônoma.

É possível, deste modo, que uma parte esteja em mora enquanto o inadimplemento de sua contraparte caracteriza-se como definitivo. Pode haver ainda mora recíproca bem como inadimplemento definitivo recíproco. Nada impede, por outro lado, que restem configurados dois descumprimentos desimportantes ou ainda um duplo adimplemento substancial. Há, portanto, uma série de combinações possíveis abarcadas na expressão inadimplemento recíproco e que necessitam ser equacionadas no caso concreto.

${ }^{256}$ Cf. item 2 do Capítulo 2 da Primeira Parte. 
O exame do Código Civil revela, entretanto, que foram contempladas apenas as consequências do inadimplemento singular das obrigações, ou seja, aquele descumprimento cometido por um dos contratantes. Tais efeitos foram objeto do capítulo anterior, o qual se dedicou à realização coativa da prestação, à execução pelo equivalente, à resolução, às perdas e danos e à exceção do contrato não cumprido. O diploma legal, por outro lado, nada esclareceu sobre o descumprimento de ambos os contratantes ${ }^{257}$.

Este cenário evidencia um descompasso entre a realidade negocial e sua disciplina jurídica. Demonstra ainda a relevância prática de um estudo que se propõe a aferir o sentido e as repercussões jurídicas do inadimplemento recíproco.

Torna-se oportuno, deste modo, investigar quais as consequências do descumprimento contratual por ambos os participantes. Vale anotar que se trata de um exame aplicado do tema, isto é, que visa a precisar as consequências do inadimplemento recíproco ocorrido no contrato de distribuição.

O presente capítulo, para tanto, procura sistematizar as respostas dadas ao problema na doutrina e também na jurisprudência. Os critérios empregados pelos magistrados e estudiosos merecem aprofundado exame com vistas a determinar, ao final, a solução mais adequada para equacionar a questão.

A identificação do critério mais adequado não basta, porém, para se alcançar um resultado verdadeiramente satisfatório para o presente esforço teórico. Faz-se necessário ir mais adiante.

O capítulo, neste sentido, busca estremar as várias combinações de inadimplemento recíproco possíveis, de modo a precisar os efeitos do descumprimento, sem, entretanto, limitar-se a uma análise estritamente casuística. O inadimplemento recíproco, por essa razão, será examinado distintamente, conforme o comportamento das partes permita a preservação da relação contratual ou acarrete a sua extinção.

No primeiro grupo, encontram-se as hipóteses de descumprimento por ambos os contratantes que, mesmo diante do inadimplemento, possibilitam a manutenção do vínculo contratual, como, por exemplo, a mora recíproca.

No outro, reúnem-se as combinações de descumprimento que conduzem à extinção do vínculo obrigacional. Vale destacar, desde logo, que nesta hipótese não é necessário que ambos os contratantes tenham descumprido definitivamente o contrato. Basta que a parte

\footnotetext{
${ }^{257}$ Sobre a ausência de regras sobre o inadimplemento de ambos os contratantes no Código Civil italiano, a doutrina assevera que o legislador não foi tão pessimista para prever tais situações, conforme aproveita transcrever: "Il codice non fu tanto pessimista da prevedere e regolare l'inadempienza reciproca". (Cf. SACCO, Rodolfo; DE NovA, Giorgio. Il contratto. Tomo II, op. cit., p. 640).
} 
lesada pelo inadimplemento definitivo de sua contraparte opte pela via resolutória para que tenha fim o vínculo.

O presente item objetiva, portanto, identificar qual o melhor tratamento para as situações de inexecução contratual por ambos os participantes. Uma vez reconhecido o critério a ser utilizado, pretende ainda verificar as repercussões jurídicas das diversas combinações de inadimplemento recíproco, as quais, para tanto, são reunidas em dois grupos conforme o contrato seja preservado ou extinto.

O capítulo, portanto, presta-se, em última análise, a completar o ordenamento legal ao oferecer soluções para o inadimplemento recíproco ocorrido no contrato de distribuição. Cumpre, então, principiar o exame de como a doutrina e a jurisprudência cuidam do tema.

\section{Breve síntese da doutrina e jurisprudência}

Na prática dos negócios, tornam-se cada vez mais frequentes as situações em que ambos os contratantes não cumprem devidamente suas obrigações. Diferentemente do que ocorre com o inadimplemento singular, não há, entretanto, previsão legal de regras que disciplinem o inadimplemento recíproco.

Revela-se indispensável, neste cenário, examinar como a doutrina e a jurisprudência têm entendido o tema. Esta investigação objetiva estabelecer a solução mais adequada para cuidar do inadimplemento recíproco do contrato de distribuição. Para a aferição desta resposta, aproveita recorrer ainda às orientações encontradas no direito estrangeiro, notadamente, o direito italiano.

A comparação jurídica revela-se assaz oportuna, seja para o simples contraste entre as orientações adotadas, seja para evidenciar que certas soluções são compatíveis em diversos países por, na verdade, albergarem os princípios que presidem todo o direito de base romanística.

Antes, porém, do recurso ao direito estrangeiro, cumpre investigar como o tema é tratado no direito pátrio.

\subsection{Direito brasileiro}

Diante da ausência de normas que disciplinem o incumprimento por ambos os participantes do contrato de distribuição, torna-se imperioso considerar a doutrina de quem já se propôs a interpretar o problema ora suscitado. Em seguida, merecem também exame 
as decisões judiciais. Os critérios empregados pelos estudiosos e magistrados serão alvo, deste modo, de minuciosa análise nas linhas que seguem, as quais pretendem perscrutar a adequação e a conveniência das soluções apontadas.

\subsubsection{Doutrina}

No que diz respeito à doutrina, o inadimplemento recíproco, mesmo que ocorrido em negócios diversos do contrato de distribuição, não provocou particular reflexão dos autores, conforme alerta um dos poucos estudos que suscita o problema ${ }^{258}$. Isto não obstante, propõe-se coligir os entendimentos da doutrina que mais de perto se aproximam do tema ora discutido.

No início do século XX, a doutrina determinou a aplicação da compensação de culpas para os casos em que o contratante de qualquer forma colaborasse para o descumprimento ${ }^{259}$.

É de se notar, todavia, que o referido jurista teve em vista situações nas quais um contratante contribuiu para o descumprimento de prestação assumida por sua contraparte. Há, deste modo, o inadimplemento de apenas uma prestação por ambos os contratantes. Trata-se, em verdade, de hipótese de concurso de culpas ou culpa concorrente, figura que não se confunde com o descumprimento recíproco.

A obra não versa, portanto, sobre um autêntico inadimplemento recíproco ou, ao menos, não nos termos enunciados neste trabalho. No inadimplemento recíproco, ambos os participantes descumprem o contrato, recaindo a inexecução sobre prestações diversas que corriam sob a responsabilidade de cada um dos contratantes.

Com o objetivo de reunir as principais opiniões doutrinárias a respeito do tema, vale assinalar também o que enuncia um dos comentários mais tradicionais ao Código Civil de 1916, o qual, apesar de não abordar especificamente o tema, dele se aproxima ao tratar da mora por parte do credor e do devedor ${ }^{260}$. O comentário ressalta que, diante da mora de ambos os contratantes, faz-se necessário distinguir a mora sucessiva da simultânea.

\footnotetext{
${ }^{258}$ Cf. Forgioni, Paula A. Teoria geral dos contratos empresariais, op. cit., p. 198. A autora, ao traçar as principais características da teoria geral dos contratos empresariais, identifica o inadimplemento recíproco ocorrido nos contratos de colaboração como uma questão dogmática em aberto no direito brasileiro.

${ }^{259}$ Nas palavras do mencionado autor: "É um caso característico da compensação da culpa, em que as duas ações se ilidem e nenhuma das partes pode contra a outra tirar vantagem da culpa que lhes é comum" (Cf. CARVAlHo DE MENDONÇA, Manuel Inácio. Doutrina prática das obrigações. Tomo II. $4^{\mathrm{a}}$ ed. aum. e atual. José de Aguiar Dias. Rio de Janeiro: Revista Forense, 1956. p. 328).

${ }^{260}$ CARVAlHo Santos, João Manoel. Código Civil Brasileiro Interpretado. Vol. XII. $10^{\mathrm{a}}$ ed. Rio de Janeiro: Freitas Bastos, 1977. p 343.
} 
Segundo o autor, na mora sucessiva, um descumprimento sobrevém ao outro, tal qual ocorre quando o devedor purga sua mora, mas o credor recusa-se, desta vez, a receber. Neste caso, a última mora elimina a primeira. Na mora concomitante, por sua vez, o inadimplemento de ambos os participantes ocorre a um só tempo. Verifica-se, nesta hipótese, a eliminação dos efeitos da mora para ambos os contratantes, exceto se a inexecução prejudicar apenas um dos contratantes.

Nos casos de mora concomitante, idêntica resposta é encontrada em obra clássica sobre a inexecução das obrigações, a qual prescreve a eliminação de ambas as moras em lugar de se considerar ambos os contratantes morosos ${ }^{261}$.

Diante do narrado acima, cumpre anotar que a doutrina brasileira apenas avizinhouse do inadimplemento recíproco ao tratar de alguns temas que com ele guardam certa ligação. O problema, a rigor, veio à tona somente recentemente em obra que se dedica a esclarecer a teoria geral dos contratos empresariais ${ }^{262}$.

O inadimplemento recíproco é tratado, neste caso, como uma questão dogmática ainda em aberto, cuja solução reclama o recurso às cláusulas gerais, em especial, a vedação do enriquecimento sem causa, o respeito à boa-fé objetiva, a proteção à legítima expectativa, os usos e costumes e, por fim, a vedação do aproveitamento da própria torpeza $^{263}$.

Nota-se, por todo o exposto, que os estudiosos do Direito pátrio pouco se dedicaram ao inadimplemento recíproco. Tal figura, para a qual falta uma norma específica, permanece como uma questão em aberto também na doutrina.

A ausência de normas e doutrina a respeito do tema revela que se trata de um problema relativamente recente na prática negocial e que se encontra intrinsecamente relacionado ao incremento do uso dos contratos de colaboração.

Não se trata, portanto, de conclusão precipitada afirmar que o inadimplemento recíproco é problema que assume maior relevância diante de arranjos mais complexos, formados por uma série de obrigações e que exigem um comportamento colaborativo de ambos os contratantes por certo período de tempo.

$\mathrm{Se}$, de um lado, a doutrina pouco trata do tema, os magistrados quando instados a decidir a respeito não podem furtar-se de oferecer uma resposta. Afigura-se, em razão

\footnotetext{
${ }^{261}$ Segundo Agostinho Alvim, "Quando a credor e o devedor vêm a faltar ao mesmo tempo, dá-se moras simultâneas, mas não para considerar ambos em mora, e sim para se considerarem eliminadas ambas as moras". (Cf. AlviM, Agostinho. Da inexecução das obrigações, op. cit, p. 86 e 166-167).

${ }^{262}$ Cf. Forgioni, Paula A. Teoria geral dos contratos empresariais, op. cit., p. 198.

${ }^{263}$ Cf. Forgioni, Paula A. Teoria geral dos contratos empresariais, op. cit., p. 200.
} 
disto, conveniente analisar como os tribunais decidem os casos de inadimplemento recíproco que lhes são apresentados.

\subsubsection{Jurisprudência}

Os tribunais apresentam algumas respostas nos tradicionais contratos de intercâmbio. Decidiu-se, na maioria das oportunidades, pela resolução do contrato e aplicação da compensação de culpas. Por força disso, determinou-se, em alguns casos, a exclusão de multa contratual, em princípio devida por ambas às partes e, nos demais, o pagamento proporcional de indenização ${ }^{264}$.

O Tribunal de Justiça de Minas Gerais, seguindo idêntica interpretação, entendeu que o descumprimento mútuo das obrigações contratuais impõe a resolução do contrato e excluiu o direito de haver quaisquer perdas e danos ou cláusula penal pelos contratantes ${ }^{265}$.

Em outro julgado, o Tribunal de Justiça de São Paulo fundamentou-se na boa-fé objetiva, na função social do contrato e na responsabilidade pós-contratual para enfrentar a questão ${ }^{266}$.

Entre tais decisões, merece ainda destaque a proferida pelo Tribunal de Justiça de São Paulo em 09 de março de 2004, na qual se discute o descumprimento, de um lado, das obrigações de pagamento assumidas pelos requeridos e, de outro, as obrigações do requerente de quitar débitos tributários e previdenciários ${ }^{267}$.

Neste julgado, propõe-se a partilha dos prejuízos em partes iguais, se forem idênticas as culpas; ou em partes proporcionais, se os graus de culpa forem distintos. No caso concretamente analisado, decidiu-se que as partes contribuíram igualmente para a resolução e, por consequência, foi determinado que os requeridos desocupassem o imóvel. O requerente, por sua vez, não teve direito a receber a multa estipulada no contrato para as hipóteses de descumprimento, mas conservou para si as quantias já pagas por sua contraparte e ainda retomou o imóvel.

No que tange à pesquisa jurisprudencial acerca do inadimplemento recíproco nos contratos de intercâmbio, vale sublinhar, por fim, que foram encontrados inúmeros arestos dedicados ao compromisso de compra e venda. A existência de julgados em Cortes que

\footnotetext{
${ }^{264}$ Entenderam pelo pagamento proporcional: $1^{\mathrm{o}}$ TACivSP, Ap. $\mathrm{n}^{\mathrm{o}} 775.233-4,3^{\mathrm{a}}$ Câm, r. Juiz Soares de Mello, j. 23.02.1999; TJSP, Ap. nº 995753-0/3, 35 a Câm. Dir. Priv., r. Des. Clovis Castelo, j. 17.03.2008. Por sua vez, pelo não cabimento da multa contratual: TJSP, Ap. Cív. no 130.705-4/6, $7^{a}$ Câm. Dir. Priv., r. Des. Sousa Lima, j. 19.02.2003; TJSP, Ap. Cív. n 266.683-4/1-00, 1ª Câm. Dir. Priv., r. Des. Laerte Nordi, j. 09.03.2004; TJSP, Ap. Cív. no 665.988-4/2-00, $6^{\text {a }}$ Câm. Dir. Priv., r. Des. Vito Guglielmi, j. 03.09.2009. ${ }^{265}$ TJMG, Ap. Cív. no 1.0351.06.070592-5/001, 12 a Câm. Cív., r. Des. Saldanha da Fonseca, j. 30.10.2013. ${ }^{266}$ Neste sentido TJSP, Ap. Cív. 7.029.588-8, $23^{\mathrm{a}}$ Câm. Dir. Priv., r. Des. Rizzatto Nunes, j. 05.03.2008.

${ }^{267}$ Cf. TJSP, Ap. Cív. no 266.683-4/1-00, $1^{\text {a }}$ Câm. Dir. Priv., r. Des. Laerte Nordi, j. 09.03.2004.
} 
ocupam diferentes graus hierárquicos no Poder Judiciário brasileiro demonstra que tal discussão é recorrente ${ }^{268}$.

Debate-se o atraso na entrega pelo promitente vendedor ante ao não pagamento de algumas parcelas pelo promitente comprador. $\mathrm{O}$ deslinde destes casos, geralmente, ocorre com a resolução do vínculo contratual e a aplicação da compensação de culpas, mediante a restituição das parcelas adimplidas integral ou parcialmente.

Realizado o exame do inadimplemento recíproco nos contratos em geral, cumpre investigar como os tribunais têm encarado tal espécie de inexecução nos contratos de distribuição.

No inadimplemento recíproco ocorrido no contrato de distribuição, o intérprete do direito em vigor se depara com uma situação em que ambos os contratantes não cumpriram seus deveres em um contrato complexo, de colaboração e de longa duração. Neste tipo negocial, portanto, o inadimplemento recíproco ganha ainda em complexidade.

As dificuldades que o tema comporta restam evidenciadas quando a pesquisa realizada nos principais tribunais pátrios revela a existência somente de cinco julgados que se enquadram exatamente nas hipóteses ora objeto de estudo. Por sua indiscutível relevância ao presente esforço teórico, cumpre examiná-los um a um.

$\mathrm{O}$ primeiro aresto faz referência a contrato de distribuição de combustíveis $^{269}$. A ação foi proposta pelo fornecedor com vistas a resolver a relação contratual e haver a multa estipulada para os casos de inadimplemento. Este imputa ao distribuidor a inobservância das cláusulas de aquisição mínima e de exclusividade. O distribuidor, por sua vez, alega em reconvenção que a parte requerente não entregou as mercadorias no prazo.

Ambos os descumprimentos foram acolhidos pelo juiz que, em consequência, decretou a extinção da avença e afastou a incidência da multa reivindicada pelo fornecedor. Determinou-se, em adição, a devolução dos equipamentos cedidos em comodato e a restituição pelo distribuidor de quantia no valor de $\mathrm{R} \$ 500.000,00$, acrescida de atualização monetária. Tal quantia foi concedida pelo fornecedor para que o distribuidor adaptasse a imagem de seu estabelecimento aos padrões da rede, conforme contrato de mútuo acessório a concessão comercial.

\footnotetext{
${ }^{268}$ Cf. STF, RE no 93.045-1, 1ª T., r. Min. Rafael Mayer, j. 08.09.1981; STJ, REsp n ${ }^{\text {o }} 493.659,4^{\text {a }}$ T., r. Min. Ruy Rosado de Aguiar, j. 17.06.2003. No Tribunal de Justiça de São Paulo, a título exemplificativo, cf. Ap. Cív. no 80.338-4/2, $1^{a}$ Câm. Dir. Priv., r. Des. Guimarães e Souza, j. 01.06.1999 e Ap. Cív. n 994.07.1122350, $4^{\text {a }}$ Câm. Dir. Priv., r. Des. Teixeira Leite, j. 12.08.2010.

${ }^{269}$ Cf. TJSP, Ap. Cív. no 991.07.027294-0, 24ª Câm. Dir. Priv., r. Des. Salles Vieira, j. 05.05.2011.
} 
O Tribunal de Alçada Cível do Estado de São Paulo decidiu caso semelhante ao narrado acima ${ }^{270}$. Trata-se, igualmente, de contrato de distribuição de combustível em que o distribuidor não adquiriu a cota mínima mensal enquanto que o fornecedor cometeu atrasos na entrega da mercadoria. Neste caso, o julgador resolveu o contrato, reduziu a multa contratualmente fixada a ser paga pelo distribuidor e determinou a devolução dos equipamentos cedidos em comodato.

O inadimplemento recíproco é tema discutido também em ação declaratória de resolução contratual cumulada com reparação de danos movida pelo distribuidor em face do fornecedor. Trata-se de contrato de distribuição de lentes esféricas, no curso do qual restou incontroverso o inadimplemento de ambos os contratantes ${ }^{271}$.

$\mathrm{Na}$ demanda, o distribuidor tem uma dívida junto ao fornecedor e discute-se ainda sua eficiência em revender as mercadorias. O fornecedor, por sua vez, efetuou constantes mudanças na política de vendas, entre as quais merece destaque a redução do prazo de pagamento para 20 dias e o limite de $5 \%$ para os descontos concedidos ao distribuidor. $\mathrm{O}$ fornecedor, em adição, inseriu outra empresa na área de atuação do distribuidor.

O juiz, ao decidir a questão, asseverou a necessidade de se realizar um exame das culpas quando se discute o descumprimento por ambos os contratantes. No caso concreto, entendeu existir culpa prevalente do fornecedor e, em menor grau, do distribuidor. Em razão disto, a indenização a ser paga ao distribuidor foi fixada no valor de $\mathrm{R} \$ 300.000,00$.

O próximo julgado que merece estudo tem em mira contrato de distribuição não escrito e com exclusividade, cujo objeto é a revenda de produtos de limpeza profissionais. A demanda foi proposta pelo distribuidor, o qual pretende obter indenização pela denúncia abrupta do fornecedor.

O distribuidor alega ainda que o fornecedor passou a atuar diretamente em sua área, atendendo os clientes de maior potencial. O fornecedor, por seu turno, justifica o rompimento do vínculo contratual pela ausência de pagamento das mercadorias adquiridas.

Ao julgar a lide, o magistrado considerou que o descumprimento do requerente foi consequência da atuação do fornecedor e, assim, assentou uma relação de causalidade entre os descumprimentos ${ }^{272}$. Reconheceu, diante disto, o direito do distribuidor ser ressarcido e

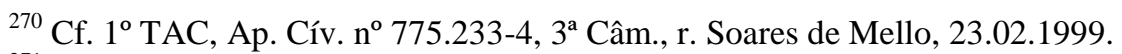

${ }^{271}$ Cf. TJSP, Ap. Cív. no 0182861-41.2006.8.26.0002, 14 ${ }^{\text {a }}$ Câm. Dir. Priv., r. Carlos Henrique Abrão, j. 28.08.2013.

${ }^{272}$ Em suas palavras: "tal atuação desleal, de usurpar a clientela de maior lucratividade formada pela autoria (...) tornou inevitável o desfecho dado à relação comercial mantida até então pelas partes".
} 
fixou a indenização pelo equivalente a 10 anos do faturamento do distribuidor nos últimos 12 meses.

Vale, por fim, mencionar uma decisão em que se discute o inadimplemento recíproco de contrato de distribuição de veículos automotores ${ }^{273}$. Diante da escassez de julgados a respeito do tema, o exame de tal decisão se revela útil, ainda que a distribuição de tal gênero de mercadorias seja regida por lei específica.

No caso em tela, decidiu-se que ambas as partes contribuíram para o desfazimento do contrato. O distribuidor por violar uma série de obrigações contraídas e o fornecedor por recorrer à resolução antes de aplicar as sanções gradativas previstas na Lei Ferrari. Neste cenário, o magistrado determinou a extinção do negócio sem a fixação de qualquer indenização ou multa.

Concluído o exame dos exíguos arestos que se dedicam ao inadimplemento recíproco do contrato de distribuição, vale proceder a uma última tentativa em busca da orientação dos tribunais pátrios.

Trata-se do exame de julgados que versam sobre o contrato de franquia. Em que pesem as diferenças entre tais negócios, os fundamentos empregados para a franquia podem servir como parâmetro comparativo para estudar a distribuição, uma vez que ambos os tipos negociais pertencem à categoria dos contratos de colaboração.

$\mathrm{Na}$ primeira demanda, o franqueador quebrou a exclusividade do franqueado ao fornecer seus produtos para empresas não franqueadas. A franqueada, por sua vez, deixou de utilizar determinada logomarca. O juiz, ao decidir o caso, não fixou qualquer indenização, nem mesmo a decorrente da perda de mercado, conforme pretendia o distribuidor, uma vez que ambas as partes contribuíram para a resolução. Noutro julgado, o fundo de comércio foi considerado de ambos em igual proporção ${ }^{274}$.

O Tribunal de Justiça do Estado do Paraná, quando instado a pronunciar-se, dispôs que o descumprimento das obrigações por ambos os contratantes deixa as partes em pé de igualdade em relação às consequências da inexecução contratual. Afirma, por outras palavras, que não é cabível a percepção de multa contratualmente prevista, se ambas as

\footnotetext{
${ }^{273}$ Cf. TJSP, Ap. Cív. no 991.07.036909-6, $18^{\text {a }}$ Câm. Dir. Priv., r. Des. Rodrigo Augusto de Oliveira, j. 24.05.2010.

${ }^{274}$ Ambas as decisões foram proferidas pelo Tribunal de Justiça de São Paulo e, na ordem mencionada, cf. Ap. Cív. $n^{\circ}$ 1263998-0, 19 ${ }^{a}$ Câm. Dir. Priv., r. Des. Mauro Conti Machado. j. 29.09.2008; e Ap. Cív. $n^{\circ}$ 991.09.023753-7. 13a Câm. Dir. Priv., r. Des. Luiz Sabbato, j. 07.04.2010.
} 
partes deram causa à quebra do negócio, conforme posição também secundada pelo Tribunal de Justiça de São Paulo ${ }^{275}$.

O exame do contrato de franquia põe fim à investigação da jurisprudência pátria sobre o inadimplemento recíproco. Foram esmiuçados julgados que tratam de tal modalidade de inexecução contratual de maneira geral, ao se analisar os contratos de intercâmbio, bem como aqueles que se dedicam propriamente ao contrato de distribuição. Frente à escassez de decisões nos contratos de distribuição, o trabalho recorreu ainda à análise daquelas que versam sobre a inexecução dos contratos de franquia.

Diante investigação empreendida, pode-se concluir pela ausência de uma orientação consolidada nos tribunais brasileiros. Esta conclusão explica-se tanto pela compreensão da figura quanto pela determinação de suas consequências.

Nota-se, primeiramente, que o conceito de inadimplemento recíproco não se encontra firme perante os tribunais, uma vez que tal figura muitas vezes é confundida com a culpa concorrente. A alusão à exceção do contrato não cumprido, muitas vezes apenas como reforço teórico, corrobora tal percepção.

No que diz respeito às repercussões jurídicas, depreende-se que a compensação de culpas é o critério mais frequente. Os tribunais adotam tal solução indistintamente, ou seja, empregam-na para todas as categorias ou tipos negociais acima considerados.

Cumpre ressaltar, todavia, que o recurso a tal ferramenta é feito, muitas vezes, sem maiores explicações sobre sua aplicação, especialmente no que diz respeito à maneira de se calcular a responsabilidade de cada contratante.

Vale destacar ainda que o uso da compensação de culpas, na maioria das oportunidades, prescinde de qualquer questionamento acerca do papel assumido pelas obrigações inadimplidas no contexto global do contrato. Esta análise, no entanto, afigurase conveniente em tipos negociais complexos como o contrato de distribuição, isto é, compostos por uma série de obrigações.

Estas considerações acerca das decisões que se dedicam ao inadimplemento recíproco, somadas às impressões anotadas anteriormente ao se examinar a doutrina, revelam a inexistência de orientação consolidada no direito pátrio sobre o tema.

A doutrina, de um lado, limita-se a estudar o inadimplemento singular e ainda são raros os trabalhos que empreendem um esforço teórico no sentido de compreender as características e as repercussões jurídicas do inadimplemento recíproco. Os julgados, de

${ }^{275}$ Cf., na ordem citada, TJPR, Ap. Cív. no 456512-2, 6 $6^{\text {a }}$ Câm. Cível, r. Des. Jefferson Alberto Johnsson, j. 11.11.2008; e TJSP, Ap. Cív. no 1002419-8, $19^{a}$ Câm. Dir. Priv., r. Des. Ricardo Negrão, j. 19.10.2009. 
outro, valem-se majoritariamente da compensação de culpas. Estes não se aprofundam, todavia, no modo de calculá-la, o que dificulta o esboço de regras de caráter geral.

$\mathrm{O}$ direito pátrio, deste modo, ainda não desenvolveu instrumental satisfatório para operar os casos de inadimplemento recíproco, sobretudo, aqueles ocorridos no contrato de distribuição. Neste cenário, salta aos olhos a conveniência de se recorrer à comparação jurídica para verificar como os problemas relacionados ao inadimplemento recíproco são tratados nos demais países de tradição romano-germânica.

\subsection{Direito estrangeiro}

A comparação jurídica é método que se reveste de especial importância quando se tem em mente que os regramentos de países como Itália e Portugal influenciaram diretamente a feitura do Código Civil de 2002. Entre tais países, vale recorrer, com maior proveito para os fins do presente trabalho, às lições do direito italiano.

Tal opção metodológica se justifica pela razoável quantidade de obras que se ocupam do assunto. A doutrina e alguns julgados peninsulares merecem, assim, ser escrutinados, mantendo-se firme o propósito de, ao final, restar identificado o critério mais adequado para resolver as situações de inadimplemento recíproco ocorrido no contrato de distribuição.

De acordo com uma das doutrinas mais aludidas nos tribunais brasileiros sobre o direito dos contratos, o inadimplemento recíproco é frequentemente alegado nos litígios. A situação emerge, via de regra, da demanda processual, na qual uma parte pleiteia a resolução da relação contratual com fundamento no inadimplemento de sua contraparte. Esta parte, por sua vez, não apenas contesta a pretensão do autor da demanda, como também imputa um descumprimento ao autor e requer, em reconvenção, a resolução ${ }^{276}$.

Neste cenário, algumas situações tornam-se possíveis, sendo necessário precisá-las, conforme aponta o autor. Se, de um lado, o juiz entende que apenas uma parte é inadimplente e a outra não ${ }^{277}$, deve ser declarada a resolução da relação contratual com fundamento no inadimplemento singular, sendo acolhida, deste modo, a pretensão da parte não inadimplente.

\footnotetext{
${ }^{276}$ Cf. RopPO, Vicenzo. Il contratto, op. cit., p. 914-915.

277 Apesar do autor não mencionar, vale observar que a parte considerada não inadimplente para fins de resolução pode ter cumprido exatamente o pactuado ou ainda ter descumprido o contrato de maneira a não embasar tal pedido. É o que ocorre diante da mora, do inadimplemento de escassa importância ou ainda do adimplemento substancial. Nota-se, diante disto, a importância de se determinar também a modalidade do descumprimento.
} 
Se, no outro extremo, nenhuma das partes descumpriu o pactuado (ou não descumpriu de modo a ensejar a resolução), ambas as pretensões não merecem acolhida. Afasta-se, assim, o inadimplemento recíproco. Resta, porém, na doutrina peninsular intenso debate sobre o destino da relação contratual nestes casos. Discute-se, mais precisamente, o cabimento ou não do pronunciamento pelo juiz da extinção da relação contratual diante do mútuo pedido de resolução. Esta situação, no entanto, será examinada com maior minúcia no item 4 do presente capítulo.

Na terceira hipótese, constata-se, frente ao mútuo pedido de resolução, que ambas as partes estão inadimplentes. Neste caso, esclarece o autor, torna-se necessário realizar uma valoração comparativa dos respectivos inadimplementos no quadro global da relação contratual com vistas a fixar, grosso modo, qual contratante é mais inadimplente.

O juiz, para tanto, deve valer-se de alguns critérios, os quais podem ser examinados individualmente ou combinados. O autor indica alguns, quais sejam: a cronologia, a causalidade e a proporcionalidade. De acordo com o primeiro critério, considera-se quem primeiro inadimpliu o pactuado. A causalidade examina se o descumprimento de uma parte é consequência do inadimplemento da outra e, caso assim seja entendido, deve-se perquirir, segundo o critério da proporcionalidade, se a reação foi adequada.

A conveniência de valorar os respectivos descumprimentos frente ao inadimplemento recíproco é apontada também em outra obra do direito italiano, a qual indica idênticos critérios para a aferição pelo juiz do descumprimento contratual e do cabimento dos pedidos de resolução ${ }^{278}$.

A doutrina, em adição aos critérios até então apontados, aponta ainda a necessidade de se aferir a repercussão do descumprimento de cada contratante diante da função econômica do contrato inadimplido ${ }^{279}$.

A valoração dos descumprimentos de cada contratante é, portanto, a interpretação predominante na doutrina peninsular para resolver as situações de inadimplemento recíproco, conforme corroborado ainda por alguns outros doutrinadores ${ }^{280}$. Estabelecida a orientação da doutrina peninsular, resta perquirir o que diz a jurisprudência deste país sobre o tema.

\footnotetext{
${ }^{278}$ Cf. GAllo, Paolo. Trattato del contratto: I rimedi, op. cit., p. 2.123.

${ }^{279}$ Cf. SACCO, Rodolfo; DE NovA, Giorgio. Il contratto. Tomo II, op. cit., p. 640-642.

${ }^{280}$ No mesmo sentido Cf. BIANCA, C. Massimo, Diritto civile: la responsabilità, op. cit., p. 281; MonGILLO, Roberta. Inadempimento e risoluzione di diritto. , op. cit., p. 183 e 227; SICCHIERO, Gianluca. La risoluzione per inadempimento, op. cit., p. 363-364; NANNI, Luca. La risoluzione del contratto per inadempimento: disciplina generale. In VISINTINI, Giovanna. Trattato della responsabilità contratuale, op. cit., p. 461-462.
} 
A valoração dos descumprimentos frente ao inadimplemento recíproco é critério pacificamente empregado também na jurisprudência, conforme demonstram alguns julgados da Corte de Cassação ${ }^{281}$. Para a exata compreensão de tal posicionamento, vale examinar um aresto, ainda que este não trate especificamente do contrato de distribuição.

Trata-se de julgado da Corte de Cassação datado de 28 de maio de 2001, no qual se discute, de um lado, a inexecução de obras de reconstrução de um edifício geminado no prazo fixado ante o descumprimento, de outro, da obrigação de pagamento ${ }^{282}$.

Ao examinar o caso, o juiz da referida lide prescreve a necessidade de se realizar um juízo de comparação com base nas condutas de ambas as partes em relação ao pactuado, diante do inadimplemento recíproco.

Nesta análise, prossegue a decisão, o juiz não pode atribuir eficácia determinante ao dado cronológico da anterioridade de um inadimplemento em relação ao outro, mas deve considerar outros critérios, como a importância de cada descumprimento na economia global do contrato.

No caso concreto, o magistrado entende que o atraso de 13 dias na entrega da obra não foi suficientemente importante para a suspensão dos pagamentos tampouco para ensejar o pedido de resolução. Afasta, deste modo, o critério meramente cronológico e vale-se da causalidade e da proporcionalidade para decidir pela resolução da relação contratual, com fundamento no descumprimento apenas da parte que não efetuou o pagamento das obras.

Diante de todo o narrado acima, não restam dúvidas sobre a orientação majoritária do direito italiano. Nas situações de inadimplemento recíproco tanto a doutrina quanto a jurisprudência recomendam a realização de uma análise valorativa dos descumprimentos frente ao negócio pactuado. Para tanto, o juiz tem a sua disposição alguns critérios cujo exame combinado fornece os fundamentos necessários para embasar a decisão sobre a resolução contratual.

A orientação adotada pelo direito italiano revela-se, em última análise, mais vocacionada a solucionar as questões envolvendo o inadimplemento recíproco do que a encontrada no direito pátrio. Trata-se de interpretação que se reveste de maior concretude em detrimento do instrumental ainda incipiente do direito brasileiro.

\footnotetext{
${ }^{281}$ Cf. SACCO, Rodolfo; DE NovA, Giorgio. Il contratto. Tomo II, op. cit., p. 640, nota 1, onde se encontra referência à uma série de decisões, as quais secundam esta orientação, entre elas: Cass. 07.12.1977, $\mathrm{n}^{\circ}$ 5295; Cass. 12.10.1978, $\mathrm{n}^{\circ}$ 4574; Cass. 24.11.1979, $\mathrm{n}^{\circ}$ 6158; Cass. 06.03.1982, $\mathrm{n}^{\circ}$ 1424; Cass. 06.02.1987, $\mathrm{n}^{\circ}$ 1187; Cass. 30.03.1989, $\mathrm{n}^{\circ}$ 1554; Cass. 30.01.1995, $\mathrm{n}^{\circ}$ 1077; Cass. 28.03.1997, $\mathrm{n}^{\circ}$ 2799; Cass. 25. 08.1998, $\mathrm{n}^{\circ}$ 8440; Cass. 27.09.1999, $\mathrm{n}^{\mathrm{o}}$ 10668; Cass. 11.07.2000, $\mathrm{n}^{\circ}$ 9176, Cass. 04.01.2002, $\mathrm{n}^{\mathrm{o}} 59$.

${ }^{282}$ Cf. Cass. 28.05.2001, no 7242.
} 
A integral compreensão da orientação peninsular requer, entretanto, que se faça uma observação. É necessário apontar que o entendimento acima narrado não cuida de todas as hipóteses possíveis de inadimplemento recíproco, concentrando-se nos casos que conduzem à resolução do vínculo contratual. A doutrina e a jurisprudência dedicam-se, por outras palavras, à resolução postulada por ambas as partes, as quais se imputam inadimplementos definitivos. Tratam, por conseguinte, apenas dos casos passíveis de provocar a extinção da relação contratual.

Cumpre notar que a inexecução das obrigações pode assumir outros contornos, de modo que se verificam combinações diversas de descumprimentos. É o caso, por exemplo, da mora recíproca. Estas situações, por sua vez, possuem consequências distintas da resolução contratual e autorizam, inclusive, a manutenção do vínculo.

O critério apontado pela doutrina italiana comporta, deste modo, uma precisão, uma vez que, no exame do caso concreto, não se pode prescindir da identificação da modalidade de inadimplemento, isto é, mora ou inadimplemento definitivo. Vale verificar, em adição, a presença ou não do adimplemento substancial e do inadimplemento de escassa importância, porquanto tais figuras impedem o recurso à resolução.

Esclarecida a resposta mais adequada para o inadimplemento recíproco, cumpre, neste momento, ir mais adiante. Além do reconhecimento da solução, a consecução dos objetivos do presente esforço teórico requer a aplicação destes critérios ao contrato de distribuição.

Para tanto, o trabalho empenha-se em apontar as repercussões jurídicas de cada combinação de descumprimento passível de ocorrer no contrato de distribuição. A mora de ambos os contratantes; a mora, de um lado, e o inadimplemento recíproco, de outro; ou ainda um duplo adimplemento substancial são exemplos das combinações de descumprimento que podem ocorrer e que reclamam a apuração de suas respectivas consequências. É justamente do que passam a cuidar as linhas a seguir.

\section{Casos de preservação da relação contratual}

As partes ao firmarem um contrato de distribuição assumem uma série de obrigações. Ao fornecedor cabe, por exemplo, entregar as mercadorias adquiridas por sua contraparte. Quando pactuada uma cláusula de exclusividade de venda, deve ainda respeitar a atuação privativa do distribuidor e se abster de realizar vendas diretas ou estabelecer um novo revendedor naquela área. 
O distribuidor também contrai diversas obrigações. Cabe a ele, por exemplo, adquirir uma cota mínima de mercadorias e manter certa quantidade em estoque. Deve ainda renunciar a vender produtos estranhos ao fornecedor, se estipulada no contrato a cláusula de exclusividade de comercialização.

É princípio basilar do direito dos contratos o cumprimento das obrigações assumidas. $\mathrm{O}$ contrato nasce para ser cumprido exatamente conforme o pactuado. $\mathrm{O}$ princípio é bastante simples: pacta sunt servanda. O não cumprimento das obrigações, entretanto, pode ocorrer pelas mais variadas circunstâncias.

No modelo jurídico preconizado no sistema pátrio, o inadimplemento das obrigações conduz unicamente a dois caminhos, quais sejam, mora ou inadimplemento definitivo, conforme a possibilidade da prestação e a utilidade desta ao credor. Em adição, o ordenamento prescreve as consequências para cada modalidade e o direito do contratante lesado ser ressarcido dos danos provocados pela inexecução.

Neste sentido, o contratante lesado pela mora de sua contraparte pode valer-se da execução específica. Diante do inadimplemento definitivo, a execução específica não figura entre os efeitos possíveis e o contratante inocente poderá optar entre resolver a relação contratual ou exigir a satisfação da prestação que se tornou para sempre irrealizável através de uma prestação substitutiva de natureza pecuniária, por meio da execução pelo equivalente.

O intérprete do direito em vigor, ao se deparar com o inadimplemento de um dos participantes do contrato de distribuição, deve, assim, ter em mente que este pode ter recaído sobre uma série de obrigações. Determinada a obrigação descumprida, faz-se necessário ainda perquirir qual a modalidade da inexecução, ou seja, mora ou inadimplemento definitivo. Feito isto, deve-se examinar, por fim, quais as repercussões previstas no ordenamento para aquela determinada modalidade de inexecução e ainda fixar a indenização cabível, com base no interesse contratual positivo ou negativo.

No caminho a ser percorrido para resolver o inadimplemento singular do contrato de distribuição, o intérprete deve atentar ainda para a resolução, uma vez que esta pode ser judicial ou, caso as partes pactuem uma cláusula resolutiva expressa, extrajudicial. Na ausência desta estipulação, cumpre notar que o recurso à resolução é impedido caso ocorra um adimplemento substancial ou um descumprimento de escassa importância. Assim, diante do inadimplemento obrigacional, a presença destas figuras também deve ser verificada. 
Este é, portanto, o panorama do inadimplemento obrigacional e de suas consequências no direito brasileiro. Ocorre, porém, que o negócio pode ser inadimplido por ambas as partes, ou seja, tanto o distribuidor quanto o fornecedor deixam de efetuar, nos termos adequados, uma prestação cujo cumprimento corria por sua conta.

No inadimplemento recíproco, verifica-se situação semelhante a dois descumprimentos unilaterais, uma vez que cada inadimplemento deve ser caracterizado de maneira autônoma, de modo a valorar cada um deles.

Isto quer dizer que pode existir mora de um contratante e inadimplemento definitivo, do outro. É possível haver ainda mora recíproca bem como inadimplemento definitivo recíproco. Nada impede, por outro lado, que restem configurados dois descumprimentos desimportantes ou ainda um duplo adimplemento substancial.

Existe, desta maneira, uma série de combinações que podem surgir diante do descumprimento de um negócio concreto. O ordenamento jurídico, porém, não traz nenhum dispositivo a respeito do tema e, em razão disto, o problema deve ser enfrentado por meio do equacionamento das ferramentas previstas para o inadimplemento singular.

De maneira simples, pode-se afirmar que é como se o caminho acima descrito fosse percorrido duas vezes e, a seguir, passasse pelas adequações necessárias. Torna-se fundamental, deste modo, perquirir quando e como a execução específica, a execução pelo equivalente, a resolução e a indenização são aplicadas no inadimplemento recíproco.

Para auferir a resposta para estas questões, o trabalho propõe a divisão das diversas combinações de inadimplemento recíproco conforme o comportamento das partes permita a preservação do contrato ou acarrete a sua extinção.

No primeiro grupo, estão reunidas as hipóteses de descumprimento por ambos os contratantes que, mesmo diante do inadimplemento, possibilitam a manutenção do vínculo contratual, como, por exemplo, a mora recíproca. No outro, reúnem-se as combinações de descumprimento que conduzem à extinção deste vínculo. Cumpre, neste momento, avançar ao exame do primeiro grupo enquanto o item seguinte dedica-se às combinações que acarretam a extinção da relação contratual.

As combinações cujas consequências permitem a manutenção da relação contratual estão organizadas, para facilitar o estudo, em seis itens. O exame sobre cada um deles pretende aclarar, especialmente, três aspectos.

$\mathrm{O}$ primeiro diz respeito às modalidades de descumprimentos abrangidas em cada variação de inadimplemento recíproco. Em seguida, cumpre perquirir as respectivas repercussões jurídicas, ou seja, examinar o cabimento da execução específica ou da 
execução pelo equivalente. Convém, por fim, apreciar a indenização cabível, estabelecendo critérios para sua quantificação. É, então, do que se passa a cuidar.

\subsection{Mora recíproca}

A primeira combinação a ser tratada é a mora recíproca. $\mathrm{Na}$ inexecução de um contrato de distribuição por ambos os participantes, esta é, provavelmente, uma das configurações de descumprimento mais frequente.

A afirmação encontra justificativa no enquadramento deste tipo negocial na categoria dos contratos de duração. O tempo de um negócio interfere diretamente na valoração da utilidade da prestação, ou seja, caso uma prestação não tenha sido realizada no tempo, no lugar ou modo convencionados, a longa duração da avença pode estender a possibilidade de seu cumprimento útil, o que explica a frequência dos casos de mora em detrimento do inadimplemento definitivo.

Na mora recíproca, ambos os contratantes deixam de efetuar, no tempo, no lugar ou modo pactuados, as prestações a que estão obrigados. A despeito disto, a execução das prestações inadimplidas ainda é possível e útil ao seu respectivo credor, ou seja, persiste para ambos os contratantes a possibilidade futura de cumprimento.

Para a exata compreensão dos casos abrangidos nesta figura, vale recorrer a alguns exemplos. Basta pensar no distribuidor, que obrigado a anunciar em jornal de grande circulação, o faz em publicação local e no fornecedor que, por sua vez, atrasa a entrega dos produtos adquiridos.

Há também mora recíproca quando, em um contrato de distribuição de softwares de computadores, o fornecedor entrega as mercadorias acompanhadas de manuais em língua estrangeira, a despeito de existirem na língua pátria, ao passo que o distribuidor não repassa ao fornecedor as solicitações do mercado para melhorias e implementações com vistas a correção de falhas no comportamento do programa (bugs).

Cumpre notar que nos casos narrados subsiste a possibilidade de cumprimento. A possibilidade de emenda que socorre a ambos os contraentes é, portanto, a característica que possibilita distinguir esta combinação das demais.

Nos casos descritos, a emenda aos descumprimentos se dá, respectivamente, com a colocação do anúncio na localidade correta e com o envio das mercadorias, manuais e informações faltantes. 
A consequência para a mora recíproca toma como fundamento a repercussão jurídica prevista para os casos de mora singular. Trata-se da realização coativa da prestação. Por meio desta, o contratante lesado pelo inadimplemento de sua contraparte pode exigir o cumprimento da prestação através de um processo de execução, de conhecimento ou ainda de uma ação monitória. Vale lembrar que a realização coativa assume contornos diversos conforme a natureza da obrigação descumprida seja de dar, fazer ou não fazer ${ }^{283}$.

Diante do inadimplemento recíproco, faz-se necessário observar que a realização coativa da prestação pode ser manejada por ambos os contratantes. $\mathrm{O}$ fornecedor, assim, pode exigir que o distribuidor cumpra a prestação que corria por sua conta; e ao distribuidor igual direito é tutelado, conforme ilustra a representação abaixo:

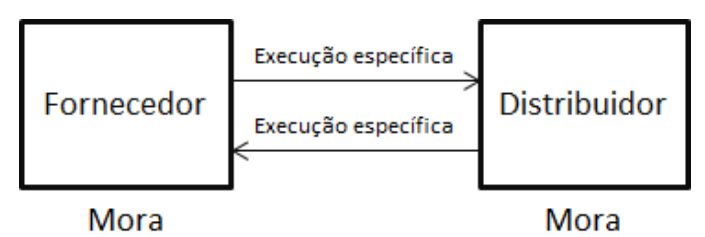

Vale, por fim, anotar que os contratantes, além da realização coativa da prestação, terão direito a exigir a reparação dos prejuízos que sofreram por não terem recebido a prestação no tempo, no lugar ou na forma devidos ${ }^{284}$.

A mora recíproca, portanto, é combinação que permite aos contratantes a emenda de seu respectivo descumprimento. Neste caso, ambos os contratantes podem valer-se da realização coativa da prestação para obter a prestação ainda não prestada ou prestada fora do lugar ou ainda de maneira diversa da pactuada. Tal combinação de inadimplemento, deste modo, não conduz a resolução da relação contratual, mantendo-a firme, mesmo após as inexecuções de ambos os contratantes.

A mora recíproca, no entanto, não é a única hipótese de descumprimento por ambos os contratantes que preserva a relação contratual. Cumpre, deste modo, prosseguir no exame das demais combinações.

\subsection{Mora e inadimplemento definitivo}

\footnotetext{
${ }^{283}$ Para a revisão das principais características da execução específica nas obrigações de dar, fazer e não fazer, consulte o item 2 do capítulo 2 da Parte II do presente trabalho.

${ }^{284}$ Vale indicar que a indenização será tratada em item próprio, uma vez que as considerações a seu respeito aplicam-se a todos os casos de inadimplemento recíproco que preservam a relação contratual. Neste sentido, consulte o item 3.7 .
} 
Outra combinação de descumprimento por ambos os contratantes cujo equacionamento das consequências permite a manutenção do vínculo envolve a mora e o inadimplemento definitivo.

Neste caso, há mora de um dos contratantes enquanto o outro descumpriu definitivamente a prestação que corria por sua conta. Vale anotar que tanto o distribuidor quanto o fornecedor podem incorrer em mora. O inadimplemento definitivo, igualmente, pode ser imputado a ambos os contratantes. O essencial para caracterizar a figura é a ocorrência de ambas as modalidades de descumprimento, sendo que cada uma delas é imputada a um dos contratantes.

Para aclarar esta situação, aproveita recorrer a um exemplo. O distribuidor, de um lado, quebra o dever de sigilo, ao divulgar uma informação que se comprometeu a proteger. $\mathrm{O}$ fornecedor, de outro, entrega as mercadorias organizadas de maneira diferente da pactuada e que, por conseguinte, não podem ser acomodadas no estoque do distribuidor. Este cumprimento, diversamente do primeiro, comporta purgação, bastando para isto o reenvio das mercadorias ordenadas de acordo com o modo convencionado.

Nesta combinação, o contratante lesado pela mora pode exigir a realização coativa da prestação, uma vez que nesta modalidade o cumprimento da prestação ainda é possível e útil ao credor. Por outro lado, o contratante moroso, mas também lesado pelo inadimplemento definitivo de sua contraparte, tem reconhecida a prerrogativa de requerer o cumprimento pelo equivalente ou, observados os demais pressupostos, a resolução do contrato.

A resolução é remédio que põe fim a relação contratual. A execução pelo equivalente, por sua vez, mantém o vínculo entre as partes e substitui a prestação que se tornou para sempre irrealizável por uma equivalente de natureza pecuniária.

No caso ora examinado, o contratante opta pela execução pelo equivalente. Ao valer-se de tal ferramenta, o contratante inocente aufere o resultado projetado que lhe fora negado pelo inadimplemento alheio através de uma prestação de natureza pecuniária.

As repercussões jurídicas desta espécie de inadimplemento recíproco podem ser expostas através da ilustração abaixo:

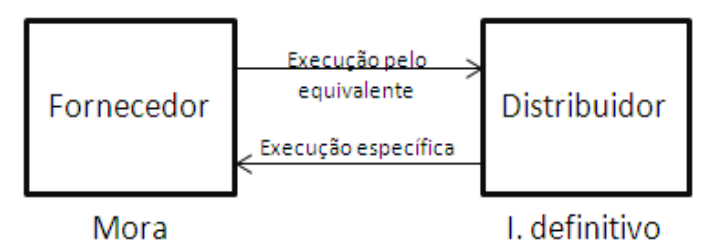


Esta combinação de inexecução demonstra que é possível a preservação do vínculo contratual ainda que um dos contratantes tenha inadimplido definitivamente uma prestação do contrato. Diante do inadimplemento definitivo de um dos contratantes, basta, assim, a opção pela execução pelo equivalente para que o vínculo seja mantido.

Cumpre ainda anotar que os contratantes, além da realização coativa da prestação e da execução pelo equivalente, terão direito a exigir a reparação dos prejuízos que sofreram em razão da mora ou do inadimplemento definitivo de sua contraparte.

Cabe observar, por fim, que tanto a indenização quanto a execução pelo equivalente possuem natureza pecuniária. Diante disto, é possível a compensação entre os pagamentos até a quantia em que as obrigações se extingam, conforme o art. 368 do Código Civil.

É o que se verifica quando, por exemplo, o distribuidor, de um lado, exige execução pelo equivalente e indenização em razão de inadimplemento definitivo de sua contraparte; e o fornecedor, de outro, requer a execução específica e o ressarcimento dos danos oriundos da mora. Neste caso, pode ocorrer a compensação entre as indenizações e, caso haja um remanescente, esta poderá atingir também a quantia a ser paga à título de execução pelo equivalente pelo fornecedor.

A combinação de mora e inadimplemento definitivo, por todo o exposto, é mais uma das hipóteses de descumprimento recíproco cujo equacionamento das consequências permite a preservação do vínculo contratual. Basta, para tanto, que o contratante lesado pelo inadimplemento definitivo opte por requerer a execução pelo equivalente, em detrimento da resolução.

É perfeitamente possível que em lugar de apenas um inadimplemento definitivo, ocorram dois, ou seja, ambos os contratantes incorram em descumprimentos de natureza definitiva no curso da relação contratual. Diante disto, torna-se conveniente nas linhas que seguem analisar o inadimplemento definitivo recíproco.

\subsection{Inadimplemento definitivo recíproco}

No inadimplemento definitivo recíproco, ambos os contratantes descumprem suas obrigações de maneira irremediável, seja em razão da impossibilidade superveniente das prestações, seja em virtude da perda da utilidade destas para o credor.

Para ilustrar tal hipótese vale pensar no distribuidor que não adquiriu a cota mínima de mercadorias destinadas ao período das festividades, ao passo que o fornecedor entregou parcela das mercadorias adquiridas apenas em janeiro. 
Apesar de tais inadimplementos de natureza definitiva, o contrato mostra-se ainda proveitoso para ambos os contratantes. $\mathrm{O}$ fornecedor continua a colocar seus produtos no mercado, enquanto que o distribuidor permanece auferindo lucros por meio da revenda daqueles. A manutenção do contrato, deste modo, aproveita a ambas as partes.

Neste cenário, os contratantes têm direito a exigir a reparação dos prejuízos sofridos em razão do inadimplemento definitivo de sua contraparte. Em adição, ambos optam por satisfazer seus interesses, antes consubstanciados na prestação descumprida, através da execução pelo equivalente, conforme indica a ilustração:

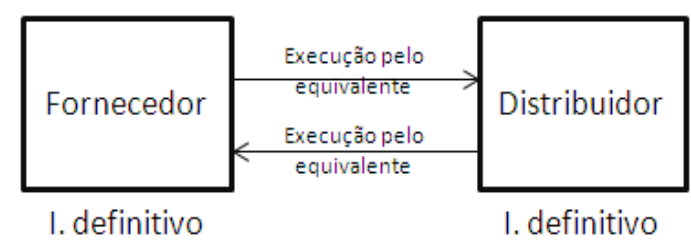

Tal escolha revela, em particular, a opção pela manutenção do vínculo contratual em detrimento de sua resolução. Demonstra também que, muitas vezes, no contrato de distribuição as partes toleram certos descumprimentos tendo em vista a manutenção do negócio, cuja existência continua a interessar a ambas as partes que ainda veem nele uma oportunidade de obter vantagens econômicas.

A opção pela execução pelo equivalente, frente a um inadimplemento de natureza definitiva, pode se justificar também pela presença de um descumprimento que, apesar de irreversível, tem caráter desimportante na economia global do negócio. Esta escolha pode ser determinada ainda pelo fato de o contratante inadimplente ter cumprido as prestações que lhe cabiam de tal maneira que o escopo do negócio foi atingido praticamente na integralidade.

Revela-se oportuno, diante disto, examinar as combinações de inadimplemento recíproco que envolvem o adimplemento substancial ou o inadimplemento de escassa importância, uma vez que tais figuras impedem o recurso à resolução.

3.4. Mora e adimplemento substancial ou inadimplemento desimportante

O adimplemento substancial ou o inadimplemento de escassa importância são figuras que emergem, geralmente, em sede de defesa diante de demanda que visa a resolver a relação contratual. 
Nestas lides, um dos contratantes alega o inadimplemento definitivo de sua contraparte e requer, por consequência, a resolução da relação contratual e a indenização pelo interesse negativo. Citado, o requerido defende-se sustentando haver um inadimplemento de escassa importância ou o adimplemento substancial.

Uma vez reconhecido o cabimento de uma destas figuras, o juiz irá declarar o pedido de resolução improcedente e extinguir o processo. Para evitar que o processo chegue ao fim, faz-se conveniente que o autor formule um pedido subsidiário. Por meio dele, deve requerer a execução pelo equivalente cumulada com a indenização do interesse positivo.

A situação até o momento narrada tem em vista o inadimplemento singular de um contrato. Nada impede, porém, que neste cenário seja acrescentado o descumprimento do próprio autor da demanda, o que configura um inadimplemento recíproco.

$\mathrm{Na}$ hipótese do inadimplemento recíproco, o requerido, além de argumentar o adimplemento substancial ou o inadimplemento de escassa importância, reconvém para alegar o descumprimento do requerente, o qual pode estar em mora ou ter inadimplido definitivamente o contrato.

Cumpre, primeiramente, investigar as repercussões jurídicas surgidas em face da mora para, no próximo item, equacionar aquelas que resultam do inadimplemento definitivo.

No caso ora analisado, há mora de um contratante e inadimplemento definitivo com escassa importância de outro. Vale pensar, por exemplo, no atraso do fornecedor em enviar as mercadorias e na não realização pelo distribuidor de propaganda publicitária destinada unicamente a determinada época do ano, como o Carnaval.

Nesta combinação de descumprimento, o distribuidor pode valer-se da realização coativa da prestação. No que diz respeito ao contratante lesado pelo inadimplemento definitivo, cumpre notar que não surge para este o direito de exigir a resolução da relação contratual. Como ilustra o exemplo, isto se deve pela presença de um inadimplemento de escassa importância.

O recurso à resolução é barrado ainda pelo adimplemento substancial, embora tal figura ocorra com menos frequência nos contratos compostos por uma série de obrigações, como o contrato de distribuição ${ }^{285}$. A título exemplificativo, pode-se pensar em um

\footnotetext{
${ }^{285}$ Os motivos para a maior frequência do inadimplemento desimportante no contrato de distribuição foram apontados no item 4.1. do Capítulo antecedente.
} 
contrato de distribuição celebrado pelo prazo de 5 anos, em que o fornecedor pretenda a resolução por não ter recebido o pagamento pela última leva de produtos entregues.

Ao fornecedor resta, deste modo, a execução pelo equivalente. As consequências desta combinação podem ser resumidas através da seguinte ilustração:

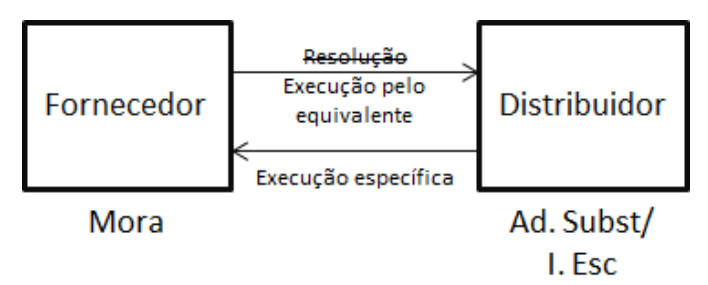

Vale, por fim, anotar que ambas as partes tem direito ainda ao ressarcimento dos prejuízos havidos em razão do descumprimento de sua contraparte.

Aclaradas as consequências de mais uma variação de inadimplemento recíproco, cumpre a seguir examinar o descumprimento que envolve, de um lado, adimplemento substancial ou inadimplemento desimportante e, de outro, o inadimplemento definitivo.

3.5. Inadimplemento definitivo e adimplemento substancial ou inadimplemento desimportante

Como narrado no item antecedente, a pretensão resolutiva de um contratante pode ser impedida diante do acolhimento pelo juiz da defesa do requerido, na qual se alegou o adimplemento substancial ou o inadimplemento de escassa importância. Na presença destas figuras, resta ao demandante, desde que tenha formulado pedido neste sentido, recorrer à execução pelo equivalente.

Por outro lado, o ordenamento assegura ao contratante contra quem é movida a demanda resolutória o direito de reconvir. $\mathrm{Na}$ reconvenção, o requerido pode alegar o descumprimento do requerente. Tal descumprimento pode assumir duas modalidades. A mora foi alvo das considerações anteriores de modo que se faz oportuno examinar o inadimplemento definitivo.

Ao contratante lesado pelo inadimplemento definitivo de sua contraparte, o direito reconhece a prerrogativa de requerer o cumprimento ou a resolução. A resolução extingue a relação contratual ao passo que a execução pelo equivalente garante a satisfação da prestação que se tornou para sempre irrealizável por meio de uma prestação substitutiva de natureza pecuniária. 
No caso ora examinado, o contratante opta pela execução pelo equivalente. Há, desta maneira, a combinação de duas execuções pelo equivalente, as quais, por apresentarem natureza pecuniária, podem ser compensadas. As repercussões jurídicas desta espécie de inadimplemento recíproco podem ser assim sintetizadas:

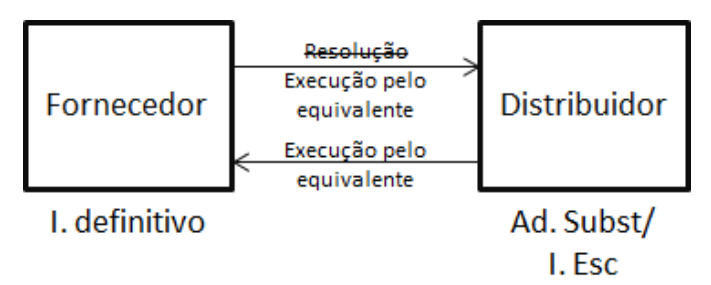

Além da execução pelo equivalente, cabe recordar que as partes têm direito ao ressarcimento dos prejuízos sofridos em razão do inadimplemento de sua contraparte.

No caso ora em tela, discute-se, assim, uma dupla execução pelo equivalente. A primeira decorre de um pedido subsidiário frente à presença do adimplemento substancial ou do inadimplemento de escassa importância, enquanto a segunda é fruto da reconvenção do requerido, na qual foi imputado um inadimplemento definitivo ao requerente.

Cumpre observar que a execução pelo equivalente não é a única ferramenta disponível ao requerido. Este pode valer-se também da resolução, desde que não estejam presentes o adimplemento substancial ou o inadimplemento de escassa importância.

Neste cenário, aponta a última combinação de descumprimento cujas consequências permitem a manutenção da relação contratual. Trata-se, mais especificamente, do adimplemento substancial recíproco ou do inadimplemento desimportante recíproco.

3.6. Adimplemento substancial recíproco ou inadimplemento desimportante recíproco

No adimplemento substancial recíproco ou no inadimplemento desimportante recíproco, ambos os contratantes descumprem definitivamente prestações por eles assumidas. Tais inadimplementos definitivos, entretanto, não são suficientes para justificar a resolução da relação contratual, uma vez que ocorre i) adimplemento substancial recíproco; ii) adimplemento substancial de uma parte e inadimplemento desimportante de outra; ou iii) inadimplemento desimportante recíproco.

No que diz respeito ao inadimplemento definitivo do contrato de distribuição, a pretensão resolutória resta afastada, mormente, pela ocorrência de um duplo 
inadimplemento de escassa importância, em razão da presença de uma série de obrigações que assumem papel diverso na economia do contrato.

Basta pensar, por exemplo, na não prestação de orientações sobre a organização de vendas pelo fornecedor ao distribuidor, enquanto este não realiza a publicidade que se comprometeu.

Nesta combinação, além da indenização, ambos os contratantes devem recorrer à execução pelo equivalente, conforme demonstra a ilustração a seguir:

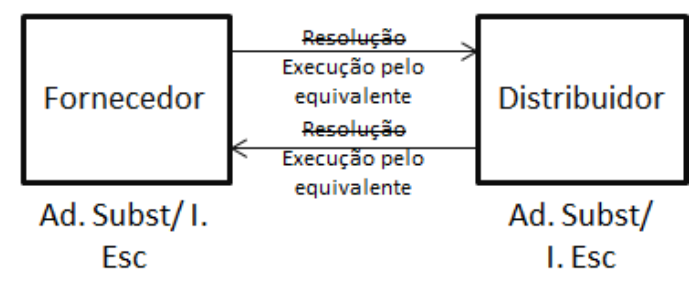

Esta combinação encerra o tratamento dos casos de inadimplemento recíproco que permitem a preservação do vínculo contratual. Antes, porém, de passar ao exame das hipóteses que conduzem à extinção, vale realizar algumas considerações acerca da indenização cabível nos casos já explorados.

\subsection{Indenização}

A indenização é o efeito geral e típico do descumprimento das obrigações, nos termos do art. 389 do Código Civil. Uma vez caracterizada a inexecução obrigacional, a parte lesada tem direito de exigir a reparação dos prejuízos havidos em razão da mora ou do inadimplemento definitivo de sua contraparte.

No inadimplemento recíproco, igualmente, o direito ao ressarcimento assiste às partes. Deste modo, desde que tenham sofrido prejuízos em razão do descumprimento de sua contraparte, tanto o distribuidor quanto o fornecedor podem pleiteá-la.

Vale observar que estas obrigações, por possuírem natureza pecuniária, podem ser alvo de compensação nos termos do art. 368 do Código Civil. As obrigações, deste modo, extinguem-se, até onde se compensarem e, caso permaneça um saldo, este deverá ser pago pelo contratante ainda devedor. Se houver acordo, tal pagamento pode ocorrer através da concessão ou redução de descontos no momento da aquisição de mercadorias do fornecedor pelo distribuidor, entre outros arranjos. 
A indenização cabível no primeiro grupo de inadimplemento recíproco, ou seja, naquele em que se preserva a relação contratual, visa a colocar o contratante na posição que estaria caso o contrato houvesse sido devidamente cumprido. Tutela, assim, o interesse contratual positivo ao cobrir os prejuízos (danos emergentes e lucros cessantes) que o credor não teria tido se a obrigação tivesse sido devidamente cumprida.

No que diz respeito à quantificação da indenização, necessário ter em vista que as perdas e danos incluem apenas os prejuízos diretos e imediatamente decorrentes do descumprimento, nos termos do art. 403 do Código Civil. Diante disto, faz-se necessário atentar que nem todo descumprimento causa idênticos danos à relação contratual.

Para a compreensão desta afirmação, aproveita recorrer à gradação dos elementos do contrato de distribuição concebida no primeiro capítulo deste trabalho, cujo resumo gráfico vale novamente trazer à tona:

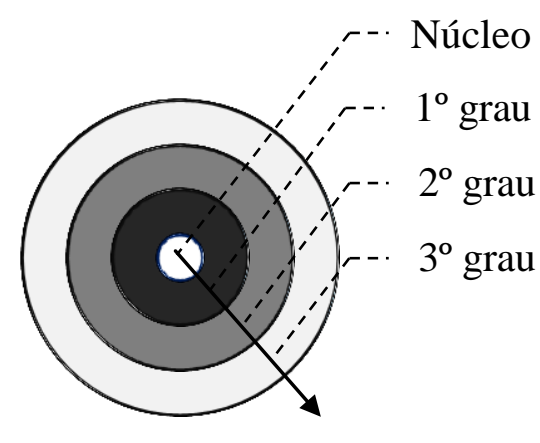

Esta gradação afigura-se de grande valia para a quantificação da indenização cabível. Isto porque, frente ao incumprimento por ambos os contratantes, a indenização tende a variar conforme a obrigação descumprida localiza-se mais próxima ou mais distante do núcleo.

O inadimplemento de obrigações situadas no núcleo do negócio tende a acarretar maiores prejuízos do que o descumprimento de obrigações localizadas no extremo oposto. Por ser tratar do centro da operação econômica, grande parte dos investimentos são direcionadas à sua consecução. Igualmente, o proveito da operação econômica depende, sobretudo, da realização destas obrigações. Em razão disto, o custo para a emenda dos danos oriundos destas obrigações tende a ser maior do que descumprimentos de obrigações mais distantes do núcleo. Assim, a indenização tende a ser maior conforme a proximidade do descumprimento do núcleo do contrato. 
O recurso à gradação finalística apresenta-se, portanto, como um parâmetro para a fixação da indenização, ao concatenar os prejuízos causados pelo descumprimento à relevância de cada obrigação na economia global do contrato. Este critério serve como parâmetro a ser empregado face ao inadimplemento recíproco. Nada impede, porém, que na prática negocial as estipulações apostas pelas partes conduzam a outra solução.

$\mathrm{O}$ exame da indenização encerra o tratamento dos casos cujas consequências, a despeito do descumprimento de ambos os contratantes, possibilitam a manutenção da relação contratual. Cumpre, neste momento, perquirir os casos de inadimplemento recíproco que levam a extinção do vínculo contratual.

\section{Casos de extinção da relação contratual}

$\mathrm{O}$ item anterior dedicou-se a examinar as combinações de inadimplemento recíproco cujas consequências, a despeito do descumprimento de ambos os contratantes, preservam a relação contratual. O presente item, por sua vez, pretende investigar os casos que conduzem à extinção da relação contratual.

A extinção da relação contratual é consequência da resolução, a qual poderá ser extrajudicial ou judicial, conforme as partes tenham pactuado ou não uma cláusula resolutiva expressa. A resolução, como vale recordar, pressupõe o inadimplemento definitivo e produz eficácia liberatória e restituitória. A restituição da resolução do contrato de distribuição segue o previsto para os contratos de duração, os quais são regrados, por analogia, pelo art. 128 do Código Civil, de modo a preservar as prestações executadas em conformidade com a natureza do negócio e as exigências da boa-fé objetiva.

Em adição, cabe recordar que a indenização cumulada à resolução é medida pelo interesse negativo. Neste caso, o credor deverá ser ressarcido por tudo o que perdeu ou deixou de ganhar por acreditar na execução do contrato. Ao optar pela resolução, no entanto, não lhe é permitido exigir o lucro que auferiria com o cumprimento do avençado.

No que diz respeito ao pedido de resolução, cumpre notar que este pode ser arguido por apenas um dos contratantes ou por ambos. É justamente através desta divisão que se propõe abordar o tema. Desta maneira, serão analisadas, primeiramente, as questões suscitadas pelo pedido de resolução de apenas um dos contratantes para, a seguir, examinar as repercussões jurídicas do duplo pedido de resolução. 
4.1. Pedido de resolução formulado por um contratante

Quando ambas as partes descumprem o contrato, mas apenas uma pede a resolução da relação contratual a doutrina diverge sobre a solução a ser adotada. A doutrina brasileira preceitua que o juiz deve acolher a demanda de cumprimento e rejeitar a aquela de resolução ${ }^{286}$. De acordo com parcela da doutrina peninsular, todavia, prevalece a demanda resolutória $^{287}$.

Um critério mais razoável é apontado em obra especialmente dedicada ao inadimplemento recíproco. Segundo o autor, diante de conflito entre uma demanda pelo cumprimento e outra de resolução, o juiz não deve decidir com base em uma preferência preestabelecida pela conservação ou extinção. Sua decisão deve pautar-se em uma valoração funcional do tipo negocial descumprido ${ }^{288}$.

A efetiva aplicação prática desta valoração requer, no entanto, a determinação de alguns critérios aptos a norteá-la. A fixação destes exige, preliminarmente, o esclarecimento de algumas questões.

No inadimplemento recíproco, coexistem dois contratantes lesados pelo descumprimento de sua contraparte, o que torna necessário verificar em que medida é possível harmonizar o interesse de ambos. Para tanto, cumpre examinar a modalidade de descumprimento e a consequência que convive com o inadimplemento definitivo ensejador da resolução.

\subsubsection{Mora e execução específica}

Na primeira hipótese, um contratante requer a resolução da relação contratual com base no inadimplemento definitivo, enquanto o outro pleiteia a execução específica fundada na mora de sua contraparte.

Diante da mora, de um lado, e do inadimplemento definitivo, de outro, tende a prevalecer a demanda resolutória, por ser fundada em modalidade de descumprimento de maior gravidade. Acolhida a resolução, esta produz efeitos liberatórios e também restituitórios, além de dar lugar à indenização pelo interesse negativo.

Nos contratos de duração, entre os quais se encontra o contrato de distribuição, a eficácia restituitória é limitada, conforme prescreve o art. 128 do Código Civil. São

\footnotetext{
${ }^{286}$ Cf. Assis, Araken de. Comentários ao Código Civil brasileiro, op. cit., p. 617.

${ }^{287}$ Cf. RoPPO, Vicenzo. Il contratto, op. cit., p. 915.

${ }^{288}$ Cf. MANTUCCI, Daniele. L'inadempimento reciproco, op. cit, p. 128.
} 
mantidas, deste modo, as prestações já executadas em conformidade com a natureza do negócio e com as exigências da boa-fé.

No que diz respeito ao pedido de execução específica, vale observar que a prestação exigida torna-se para sempre irrealizável diante do acolhimento da resolução e, em vista disto, converte-se em inadimplemento definitivo. A prestação em espécie (de dar, fazer ou não fazer) é substituída, deste modo, por outra de natureza pecuniária. Pode-se dizer, assim, que há pendente uma execução pelo equivalente circunscrita àquela prestação descumprida.

O direito ao equivalente e à indenização por conta da mora, então convertida em inadimplemento definitivo, não são afastados pela resolução, por se tratarem de consequências próprias a um incumprimento de uma prestação à época exigível e cuja preservação da eficácia, ainda que transformada, é assegurada pelo princípio da boa-fé, nos termos do art. 128 do Código Civil. Tal indenização não se liga a resolução, mas ao cumprimento do contrato e tutela, portanto, um interesse contratual positivo. Neste caso, haverá compensação entre esta indenização e aquela que tutela o interesse negativo, oriunda da resolução.

Nota-se, diante do exposto, que esta combinação não suscita maiores problemas. Prevalece a pretensão resolutiva da parte lesada pelo inadimplemento definitivo em detrimento da demanda pelo cumprimento sustentada pelo contratante lesado pela mora. Em adição, vale anotar que a boa-fé nos termos do art. 128 do Código Civil exige que os prejuízos decorrentes da mora também sejam ressarcidos. Desta maneira, foram compatibilizados os interesses de ambos os contratantes.

Aclarada esta combinação, cumpre, neste momento, investigar como harmonizar um pedido de resolução e outro de execução pelo equivalente, sendo ambos os pedidos fundados em inadimplementos definitivos.

\subsubsection{Inadimplemento definitivo e execução pelo equivalente}

Nesta hipótese, ocorre a contraposição de uma demanda resolutiva e outra que busca a execução pelo equivalente. Vale precisar que ambas as pretensões estão fundadas no inadimplemento definitivo imputável à contraparte.

A compatibilização entre tais consequências não representa tarefa fácil. Em particular, vale observar que nem sempre é possível tutelar os interesses da execução pelo equivalente com a presença do efeito retroativo da resolução. Para ilustrar tal dificuldade, vale pensar em como requerer, por meio da execução pelo equivalente, lucros cessantes 
diante da resolução. A resolução põe fim à relação contratual enquanto os lucros cessantes pretendem cobrir o que o contratante ganharia com o efetivo cumprimento do contrato.

Neste cenário, para o correto equacionamento das situações apresentadas, faz-se conveniente proceder a uma nova distinção. São separados, assim, os casos em que o contratante recorreu à execução pelo equivalente por opção ou pela falta dela.

No caso em que o contratante requereu à execução pelo equivalente porque outra opção não lhe cabia, deve-se depreender a presença de um adimplemento substancial ou de um inadimplemento de escassa importância de sua contraparte. Ocorre que o inadimplemento definitivo ensejador da resolução é, por definição, mais grave do que o adimplemento substancial ou o inadimplemento desimportante, o que resta evidenciado até mesmo pelas escolhas de cada contratante. Em razão disto, a resolução tende a prevalecer.

Por outro lado, é possível que o recurso à execução específica tenha sido uma opção do contratante. Neste caso, a execução específica não foi escolhida em virtude da presença de adimplemento substancial ou inadimplemento desimportante. Trata-se de escolha feita pelo próprio contratante com base na faculdade que lhe é outorgada pelo art. 475 do Código Civil.

Esta escolha revela que os descumprimentos de ambos os contratantes possuem, perante o ordenamento jurídico, idêntico peso. São dois inadimplementos definitivos capazes de ensejar a resolução da relação contratual. Ocorre que cada contratante requer uma solução diversa, sendo que o ordenamento assegura a ambos o direito exercer a solução pleiteada, conforme enuncia o art. 475 do Código Civil.

Nesta hipótese, portanto, a colisão de direitos não pode ser resolvida pelo recurso às características dos descumprimentos. Se nos demais casos a prevalência da demanda resolutiva foi determinada através da distinção, primeiramente, entre inadimplemento definitivo e mora e, depois, entre inadimplemento definitivo e adimplemento substancial ou inadimplemento de escassa importância, tal expediente não se revela útil no caso ora discutido.

A solução para este caso de colisão, deste modo, não mais pode ser atingida abstratamente. A resposta, conforme preceitua a doutrina ${ }^{289}$, reclama que se verifique, em concreto, se algum descumprimento deve ser considerado superior de modo a determinar o cabimento de uma ou outra consequência, quais sejam, resolução ou execução pelo equivalente. Para o exame concreto, o julgador pode valer-se de alguns critérios:

${ }^{289}$ Cf. Menezes Cordeiro. António. Tratado de Direito Civil. Vol 5. Coimbra: Almedina, 2011. p. 393. 
a) importância do descumprimento

Deve-se perquirir a relevância do descumprimento de cada prestação para a economia global do contrato. Para tanto, a gradação finalística releva-se particularmente útil, uma vez que o descumprimento de uma obrigação situada no núcleo tende a ser mais importante do que o inadimplemento de outra localizada no extremo oposto;

b) minimização dos danos

Deve-se investigar ainda qual solução que gera menos danos aos contratantes;

c) sacrifício causado

Revela-se útil também analisar o sacrifício causado pela escolha de cada consequência às partes. Examina-se por este critério, por exemplo, o quanto de empenho das partes a realização das restituições exige.

Se o empate entre os descumprimentos ainda assim persistir, a consequência prevalente deve ser determinada por meio da equidade. Uma vez estabelecido que a execução pelo equivalente prevalece operam-se os efeitos desta e deve-se rejeitar a resolução. Inversamente, caso a sentença acolha a demanda resolutiva, a relação contratual é extinta e produzem-se os efeitos típicos da resolução.

Cumpre, por fim, observar que ao se buscar critérios para estabelecer o descumprimento e a consequência que prevalece em face da colisão de direitos, chega-se a uma solução muito semelhante aquela encontrada no Código Civil português. Tal diploma legal, diferentemente do Código pátrio, regula a colisão de direitos em seu art. 335.

Diante de todo o exposto, foi possível fixar algumas diretrizes que permitem compatibilizar os interesses de ambos os contratantes nas hipóteses em que o pedido de resolução é formulado por apenas um deles, enquanto o contratante requer a execução específica ou a execução pelo equivalente.

É de se notar, entretanto, que o pedido de resolução também pode ser formulado por ambos os contratantes. É do que cuida o item a seguir.

\subsection{Pedidos de resolução formulados por ambos os contratantes}

A constatação de que ambos os contratantes descumpriram suas prestação pode ocasionar um duplo pedido de resolução da relação contratual, desde que ambos os descumprimentos possuam natureza definitiva.

Trata-se da última hipótese de inadimplemento recíproco a ser tratada. Na prática, a frequência com que será aplicada, no entanto, é pequena, sobretudo no inadimplemento do 
contrato de distribuição. Isto porque sua configuração requer que o descumprimento de ambos os contratantes seja definitivo, que não reste configurado o adimplemento substancial ou um inadimplemento de escassa importância e, ainda, que ambos os contratantes optem pela resolução, ao invés da execução pelo equivalente.

A possibilidade do acolhimento de duas pretensões resolutivas é, em verdade, alvo de divergência doutrinária. Uma parcela da doutrina sustenta que o desfecho adequado para a contraposição de ações resolutivas é a improcedência de ambas ${ }^{290}$. Para outros, não há nenhum obstáculo que impeça a declaração da resolução com base no inadimplemento definitivo recíproco ${ }^{291}$.

A conveniência de se adotar uma ou outra orientação requer que se analise, primeiramente, a modalidade de cada descumprimento. Em adição, deve-se investigar se o contratante não contribuiu para que sua contraparte tenha inadimplido a prestação que, agora, motiva sua demanda resolutiva.

Se ambos os descumprimentos possuem natureza definitiva e se o contratante, a demandar a resolução, não contribuiu para o inadimplemento definitivo da prestação que corria por conta de sua contraparte, não há razão para o não cabimento da resolução.

Nesta hipótese, o juiz deve declarar a resolução do vínculo contratual, liberando os contratantes de seu cumprimento e procedendo, em liquidação, às restituições devidas de acordo com o art. 128 do Código Civil. Em adição, as partes têm direito ao ressarcimento dos prejuízos oriundos do inadimplemento definitivo de sua contraparte.

Esta indenização, cumulada à resolução, tutela o interesse contratual negativo e, deste modo, o credor deverá ser ressarcido por tudo o que perdeu ou deixou de ganhar por acreditar na execução do contrato.

No outro extremo, é possível que o juiz, ao analisar o caso que foi lhe apresentado, entenda não ter havido o inadimplemento definitivo de nenhum contratante. Neste caso, as demandas resolutivas devem ser afastadas e o vínculo contratual mantido.

Tal solução pode ser questionada, sobretudo ao se considerar o tempo de duração das discussões no poder judiciário. Não cabe ao juiz, porém, extinguir a relação contratual com base em um suposto mútuo dissenso simplesmente porque as partes valeram-se de

\footnotetext{
${ }^{290}$ Cf. Assis, Araken de. Comentários ao Código Civil brasileiro, op. cit., p. 617. Na doutrina peninsular, a orientação também encontrada em BIANCA, C. Massimo, Diritto civile: la responsabilità, op. cit., p. 281-282. Segundo o último autor, deve-se rejeitar a demanda resolutiva proposta por ambas as partes, o contrato, no entanto, deve ser considerado extinto em razão do manifesto desinteresse de ambas.

${ }^{291}$ Cf. GAllo, Paolo. Trattato del contratto: I rimedi, op. cit., p. 2.124; RoPPO, Vicenzo. Il contratto, op. cit., p. 915; e SACCO, Rodolfo; DE Nova, Giorgio. SACCO, Rodolfo; DE NovA, Giorgio. Il contratto. Tomo II, op. cit., p. 642.
} 
ações resolutivas. Neste caso, o juiz deve, assim, apenas refutar a resolução, deixando às partes a decisão, posterior, de extinguir o contrato ou mantê-1o ${ }^{292}$.

Cumpre, por fim, precisar que não há um descumprimento recíproco quando o inadimplemento de uma parte é causado pela inexecução da outra. Basta pensar, para ilustrar este caso, no distribuidor que violou a cláusula de estoque mínimo, em razão do atraso na entrega das mercadorias pelo fornecedor. Nesta hipótese, há, assim, apenas o inadimplemento de um dos participantes do contrato.

O exame do duplo pedido de resolução, baseado no inadimplemento definitivo de ambos os contratantes, é a última combinação de inadimplemento cuja consequência conduz a extinção da relação contratual. O capítulo, diante disto, examinou e fixou as consequências de todas as combinações de inadimplemento passíveis de ocorrência no contrato de distribuição.

\section{Conclusões preliminares}

Na prática comercial, tornam-se cada vez mais corriqueiras situações em que ambos os contratantes não cumprem exatamente suas obrigações. No contrato de distribuição, por se tratar de negócio destinado a ter longa duração e que requer a atuação colaborativa das partes, os conflitos decorrentes da inexecução recíproca das obrigações contraídas tornamse ainda mais frequentes.

O exame do Código Civil revelou que foram contempladas as consequências do inadimplemento singular das obrigações. O diploma legal nada dispõe, porém, a respeito da inexecução por ambos os contratantes, razão pela qual se mostra oportuna à intervenção da doutrina no particular.

Neste cenário, o presente capítulo dedicou-se a aclarar as consequências do inadimplemento recíproco das obrigações. A partir de um estudo aplicado ao contrato de distribuição, o capítulo pretendeu, mais precisamente, realizar uma análise sistemática do tema, ao combinar as modalidades de inadimplemento incorridas por cada contratante às respectivas consequências.

Para tanto, o capítulo buscou, primeiramente, sistematizar as respostas dadas ao inadimplemento recíproco pela doutrina e jurisprudência. $\mathrm{O}$ exame do direito pátrio, no

\footnotetext{
${ }^{292}$ Neste sentido, cf. Assis, Araken de. Comentários ao Código Civil brasileiro, op. cit., p. 616; Gallo, Paolo. Trattato del contratto: I rimedi, op. cit., p. 2.124; e RopPo, Vicenzo. Il contratto, op. cit., p. 915. Por outro lado, a orientação a favor da extinção da relação contratual é encontrada em SICCHIERO, Gianluca. La risoluzione per inadempimento, op. cit., p. 364.
} 
entanto, mostrou-se insuficiente e, diante disto, recorreu-se ao direito italiano. O direito peninsular, frente ao descumprimento de ambos os contratante, prescreve a necessidade de se valorar cada inadimplemento.

Este critério revelou-se mais adequado para solucionar as questões envolvendo o inadimplemento recíproco. A mera identificação do critério, entretanto, não basta para a satisfação dos objetivos do trabalho e, em razão disto, o capítulo passou a investigar como aplicá-lo ao inadimplemento recíproco ocorrido no contrato de distribuição. Para tal aplicação, as diversas combinações de descumprimento foram reunidas em dois grupos. $\mathrm{O}$ primeiro dedicou-se a examinar as combinações de inadimplemento cujas consequências permitem a manutenção do vínculo contratual, enquanto o segundo cuida das hipóteses que conduzem à extinção.

Nas combinações de descumprimentos tratadas no primeiro grupo, notou-se que os contratantes valem-se apenas da execução específica e da execução pelo equivalente para a satisfação de seus interesses. A análise empreendida demonstrou a possibilidade da compatibilização destas figuras, de modo a harmonizar a tutela do interesse de ambos os contratantes.

No que diz respeito à indenização cabível, vale anotar que esta tutela o interesse contratual positivo. Para a fixação do quantum a ser indenizado, revelou-se particularmente útil recorrer à gradação finalística dos elementos do contrato de distribuição.

As soluções apresentadas no exame destas hipóteses podem ser assim sistematizadas:

\begin{tabular}{|c|c|c|c|c|c|}
\hline \multicolumn{6}{|c|}{ MANUtENÇÃo dA RELAÇÃo CONTRATUAL } \\
\hline \multicolumn{3}{|c|}{ Combinação 1} & \multicolumn{3}{|c|}{ Combinação 2} \\
\hline Modalidade & Consequência & Indenização & Modalidade & Consequência & Indenização \\
\hline Mora & Execução específica & Interesse positivo & Mora & Execução específica & Interesse positivo \\
\hline Mora & Execução específica & Interesse positivo & I. definitivo & $\begin{array}{c}\text { Execução pelo } \\
\text { equivalente }\end{array}$ & Interesse positivo \\
\hline \multicolumn{3}{|c|}{ Combinação 3} & \multicolumn{3}{|c|}{ Combinação 4} \\
\hline Modalidade & Consequência & Indenização & Modalidade & Consequência & Indenização \\
\hline I. definitivo & $\begin{array}{l}\text { Execução pelo } \\
\text { equivalente }\end{array}$ & Interesse positivo & Mora & Execução específica & Interesse positivo \\
\hline I. definitivo & $\begin{array}{c}\text { Execução pelo } \\
\text { equivalente }\end{array}$ & Interesse positivo & Ad. Sub/I. Esc & $\begin{array}{c}\text { Resoluçãa } \\
\text { PS: Ex. equivalente }\end{array}$ & $\begin{array}{l}\text { Interese negative } \\
\text { Interesse positivo }\end{array}$ \\
\hline \multicolumn{3}{|c|}{ Combinação 5} & \multicolumn{3}{|c|}{ Combinação 6} \\
\hline Modalidade & Consequências & Indenização & Modalidade & Consequência & Indenização \\
\hline I. definitivo & $\begin{array}{c}\text { Execução pelo } \\
\text { equivalente }\end{array}$ & Interesse positivo & Ad. Sub/I. Esc & $\begin{array}{l}\text { Resolução } \\
\text { PS: Ex. equivalente }\end{array}$ & $\begin{array}{l}\text { Interese negative } \\
\text { Interesse positivo }\end{array}$ \\
\hline Ad. Sub/I. Esc & $\begin{array}{l}\text { Resoluçấe } \\
\text { PS: Ex. equivalente }\end{array}$ & $\begin{array}{l}\text { Interesse negative } \\
\text { Interesse positivo }\end{array}$ & Ad. Sub/I. Esc & $\begin{array}{c}\text { Resoluçãa } \\
\text { PS: Ex. equivalente }\end{array}$ & $\begin{array}{l}\text { Interesse negative } \\
\text { Interesse positivo }\end{array}$ \\
\hline
\end{tabular}


No segundo grupo, foram reunidas as combinações de inadimplemento cujas consequências conduzem (ou tendem a conduzir) à extinção da relação jurídica contratual. Tais casos, por sua vez, foram organizados, com vistas a facilitar o estudo, conforme o pedido de resolução tenha sido efetuado por um ou por ambos os contratantes.

O exame do duplo pedido de resolução demonstrou que tal combinação não acarreta particular dificuldade para conciliar os interesses das partes. Comprovados os inadimplementos definitivos de ambos os contratantes, o juiz deve acolher as pretensões resolutivas e extinguir a relação contratual. Deve ainda proceder à liquidação das restituições de acordo com prescrito no art. 128 do Código Civil e determinar o pagamento das indenizações pelo interesse contratual negativo.

Por outro lado, o exame dos casos em que o pedido de resolução foi formulado por apenas um dos contratantes revelou-se complexo. Nestas situações, constatou-se uma autêntica colisão de direitos, nas quais nem sempre se mostrou possível harmonizá-los, sendo necessário determinar aquele que prevalece.

A combinação de execução específica e resolução pode ser resolvida mediante a análise das modalidades de descumprimento incorridas por cada contratante, uma vez que o inadimplemento definitivo é, por definição, mais grave que mora. Constatou-se, ao se equacionar as consequências deste caso, que o direito ao equivalente e à indenização por conta da mora, então convertida em inadimplemento definitivo, não são afastados pela resolução. O fundamento para a preservação da eficácia desta prestação encontra-se na boa-fé prevista no art. 128 do Código Civil.

A coexistência de inadimplementos definitivos recíprocos e a contraposição de demanda resolutiva e de cumprimento pela execução pelo equivalente revelou-se a mais tortuosa das colisões de direitos. Nesta hipótese, a determinação da superioridade de um pedido ou de outro exige a consideração de algumas questões. Fez-se necessário perquirir, inicialmente, o porquê da escolha pelo pedido de execução pelo equivalente.

Caso tenha sido uma opção, a tarefa torna-se ainda mais árdua e a solução pode ser determinada apenas no caso concreto através da análise de alguns critérios, como a importância do descumprimento, a minimização dos danos e o sacrifício imposto por um ou outro caminho. Caso nem assim o impasse seja resolvido, impõe-se a decisão conforme a equidade.

As respostas apresentadas no exame dos casos cujas consequências conduzem à extinção da relação contratual podem ser assim sistematizadas: 


\section{RESOLução da RELAÇão Contratual}

\begin{tabular}{|c|c|c|c|}
\hline \multicolumn{4}{|c|}{ Combinação 1- Pedido de resolução formulado por um contratante } \\
\hline \multicolumn{2}{|c|}{ Modalidade } & Consequência & Indenização \\
\hline Mora & I. Definitivo & Resolução & Interesse negativo \\
\hline I. definitivo & $\begin{array}{c}\text { I. definitivo } \\
\text { (Ad. Sub/ I. Esc) }\end{array}$ & $\begin{array}{l}\text { Exeuçãopeloguivalente } \\
\text { Resolução }\end{array}$ & Interesse negativo \\
\hline I. definitivo & I. definitivo & $\begin{array}{c}\text { Execução pelo equivalente } \\
\text { ou } \\
\text { Resolução }\end{array}$ & $\begin{array}{l}\text { Interesse positivo } \\
\text { Interesse negativo }\end{array}$ \\
\hline \multicolumn{4}{|c|}{ Combinação 2 - Pedido de resolução formulado por ambos os contratantes } \\
\hline \multicolumn{2}{|c|}{ Modalidade } & Consequência & Indenização \\
\hline \multicolumn{2}{|c|}{ Inadimplemento definitivo } & Resolução & Interesse negativo \\
\hline
\end{tabular}

Da análise das combinações de inadimplementos podem-se depreender algumas conclusões. Nota-se, primeiramente, que as hipóteses que conduzem à resolução suscitam questões complexas e apresentam maior potencial conflituoso do que as combinações de inadimplemento que possibilitam a manutenção do contrato. Por outro lado, vale notar que as combinações que preservam a relação contratual são mais numerosas do que aquelas que a extinguem.

As respostas apresentadas para o inadimplemento recíproco do contrato de distribuição demonstram ainda ser possível encontrar no ordenamento meios para harmonizar os interesses dos contratantes diante dos descumprimentos, ainda que recíprocos, para viabilizar que negócios de duração, como o contrato de distribuição, se protraiam no tempo. 


\section{CONCLUSÕES}

O presente esforço teórico ocupou-se de problema ainda pouco investigado no direito brasileiro, qual seja, a caracterização e a determinação das consequências do inadimplemento recíproco ocorrido no contrato de distribuição. Trata-se de tema que se situa nos limites entre direito civil e direito empresarial e que, em detrimento de sua crescente relevância prática, não possui uma orientação definida.

São em situações como esta que o trabalho do pesquisador do Direito afigura-se essencial. A essência do Direito, ensinava Ihering, é a sua realização prática ${ }^{293}$, de modo que não se pode poupar esforços na busca de uma resposta coerente ao problema.

Firme neste propósito, o trabalho principiou por caracterizar o contrato de distribuição segundo seu plano de existência, diferenciando-o de tipos que com ele guardam semelhança e enquadrando-o em categorias superiores que permitem lançar as bases para solucionar os problemas advindos do inadimplemento contratual, especialmente no que se refere às características que emergem de sua classificação como um contrato de duração e de colaboração.

Em particular, o desenvolvimento de uma teoria geral do contrato de distribuição vocacionada a moldar o inadimplemento recíproco contribuiu para que fosse notada a diferença de função de cada obrigação que compõe o contrato de distribuição, de maneira a permitir a realização de uma nova divisão dos elementos do tipo negocial, a chamada gradação finalística.

Qualificado o contrato de distribuição, pode-se prosseguir na caracterização do segundo instituto investigado, qual seja, o inadimplemento recíproco. Determinou-se que a expressão inadimplemento recíproco indica as situações em que ambas as partes deixam de efetuar, nos termos adequados, as prestações a que estão obrigadas. Neste cenário, tornouse necessário analisar as modalidades de descumprimento em que podem incorrer cada contratante. Constatou-se, assim, que, no modelo jurídico preconizado no sistema pátrio, o inadimplemento das obrigações conduz apenas a dois caminhos. São eles a mora e o inadimplemento definitivo.

O critério legal para estremar um do outro é a permanência da possibilidade e utilidade da prestação para o credor. Mais simples nos contratos de execução instantânea, a distinção se revelou complexa nos contratos de duração, entre os quais se enquadra o

\footnotetext{
${ }^{293}$ Cf. IHERING, Rudolf Von. A luta pelo direito., op. cit., p. 43.
} 
contrato de distribuição. Para aferi-la, o trabalho propôs o recurso à diversas balizas, como a perda de mercado, a extensão temporal, o exame das conjunturas de mercado e os custos para a retomada do negócio. Sem poder recorrer à orientação doutrinária específica, talvez essa seja uma das principais contribuições do estudo ao aprimoramento da ciência jurídica.

Identificados e caracterizados os institutos envolvidos, o trabalho pode avançar nos seus propósitos. Deu início, assim, às investigações acerca das consequências do inadimplemento recíproco ocorrido no contrato de distribuição.

Em busca de um resultado satisfatório, procedeu-se, inicialmente, ao exame das consequências previstas pelo ordenamento pátrio para o inadimplemento singular. Neste particular, restou acertado que à mora liga-se a execução específica e ao inadimplemento definitivo, a execução pelo equivalente ou a resolução.

No que diz respeito aos efeitos da resolução, verificou-se que a eficácia restituitória que atinge o contrato de distribuição é regida pelo art. 128 do Código Civil e, deste modo, limita-se em profundidade com vistas a preservar as prestações executadas em conformidade com a natureza do negócio e as exigências da boa-fé objetiva.

Fez-se certo também que em todas as modalidades de descumprimento, o prejudicado pode requerer o pagamento de indenização. Há, entretanto, uma diferença importante. Na execução, seja específica, seja pelo equivalente, o ressarcimento é pautado pelo interesse positivo e mira pôr a parte na posição em que estaria se o contrato fosse regularmente cumprido. Na resolução, o ressarcimento é calculado com base no interesse negativo e mira pôr a parte na situação em que estaria se não tivesse concluído o contrato.

Identificar com acuidade as consequências previstas para cada modalidade de descumprimento permitiu construir as bases teóricas necessárias para a, em seguida, fixar as consequências do inadimplemento recíproco, já que o regramento pátrio nada dispõe sobre a inexecução por ambos os contratantes.

Frente à ausência de regras próprias, a construção de uma resposta que permitisse resolver as diversas hipóteses de inadimplemento recíproco ocorridas no contrato de distribuição exigiu a realização de um exame concatenado de todos os temas anteriormente investigados. Foi essencial, assim, combinar modalidade de inadimplemento às respectivas consequências para a determinação da repercussão de cada combinação de descumprimento que se apresentou, nunca perdendo de vista as características inerentes ao contrato de distribuição, em particular, seu enquadramento como um contrato de duração e de colaboração. 
Foi-se, assim, estabelecido que o inadimplemento recíproco, em linhas gerais, pode provocar consequências que permitem à manutenção do vínculo e outras que extinguem a relação jurídica contratual. Nas primeiras situações, revelou-se ser possível a compatibilização dos interesses de distribuidor e fornecedor em torno da execução específica, da execução pelo equivalente e da indenização pelo interesse contratual positivo.

O exame do duplo pedido de resolução demonstrou que tal combinação não acarreta particular dificuldade para conciliar os interesses das partes. Por outro lado, o exame dos casos em que o pedido de resolução foi formulado por apenas um dos contratantes revelou-se complexo. Nestas situações, constatou-se uma autêntica colisão de direitos, nas quais nem sempre se mostrou possível harmonizá-los, sendo necessário determinar aquele que prevalece.

A combinação de execução específica e resolução pode ser resolvida mediante a análise das modalidades de descumprimento incorridas por cada contratante, uma vez que o inadimplemento definitivo é, por definição, mais grave que mora. Constatou-se, ao se equacionar as consequências deste caso, que o direito ao equivalente e à indenização por conta da mora, então convertida em inadimplemento definitivo, não são afastados pela resolução. Trata-se de aplicação do princípio da boa-fé, conforme prescrito no art. 128 do Código Civil.

Revelou-se, por fim, particularmente tortuosa a situação em que, diante do inadimplemento definitivo, um contratante opta por resolver o contrato enquanto o outro requer o seu cumprimento. Nesta hipótese, o intérprete do direito em vigor se depara com uma autêntica colisão de direito, não podendo o trabalho furtar-se de estabelecer alguns parâmetros para a determinação da superioridade de um ou outro direito, como vem a ser a importância do descumprimento, a minimização dos danos e o sacrifício causado pela escolha de cada consequência.

Por todo o exposto, conclui-se que o equacionamento do inadimplemento recíproco no contrato de distribuição reclama solução engenhosa. Primeiro, faz-se necessário conjugar as normas projetadas pelo ordenamento para o inadimplemento singular, verificadas nos contratos de intercâmbio. Em seguida, tais respostas devem ser adaptadas à realidade própria aos contratos de duração e colaboração, como a distribuição.

O percurso, embora árduo, se justifica. Negócio fundamental da economia contemporânea, o contrato de distribuição merece ser estudado de maneira sempre mais 
aprofundada, para que as partes recebam o justo julgamento diante das faltas que cometerem.

Separar o certo do errado é uma tarefa sem fim. Caminhar adiante é tudo o que se pode exigir, a bem do progresso do direito privado e, consequentemente, das relações humanas. 


\section{BIBLIOGRAFIA}

Aguiar júnior, Ruy Rosado. Comentários ao novo Código Civil. Vol. VI, tomo II: da extinção do contrato. Coord. Sálvio de Figueiredo Teixeira. Rio de Janeiro: Forense, 2011.

ALBERT, Daniel Vázquez. Los contratos de distribución comercial: Novedades legislativas y jurisprudenciales. Valencia: Tirant Lo Blanch, 2010.

Alvim, Agostinho. Da inexecução das obrigações e suas consequências. $5^{\text {a }}$ ed. São Paulo: Saraiva, 1980.

AntUnes VAREla, João de Matos. Das obrigações em geral. Vol II. $3^{\text {a }}$ reimp. da $7^{\text {a }}$ ed. Coimbra: Almedina, 1997.

João de Matos. Das obrigações em geral. Vol. I. 10. ed. rev. e atual., $5^{\text {a }}$. reimp. da edição de 2000. Coimbra: Almedina, 2008.

AsCARELl, Tullio. Corso di Diritto Commerciale: Introduzione e Teoria dell'impresa. $3^{\mathrm{a}}$ ed. Milano: Giuffrè, 1962.

Assis, Araken de. Dano positivo e dano negativo na dissolução do contrato. Revista do Advogado, São Paulo, v. 44, p. 20-23, 1994.

Araken de. Resolução do contrato por inadimplemento. $4^{\mathrm{a}}$ ed. rev. e atual. São Paulo: Editora Revista dos Tribunais, 2004.

Araken de. Comentários ao Código Civil brasileiro. Vol. V: do direito das obrigações. Coord. Arruda Alvim e Thereza Alvim. Rio de Janeiro: Forense, 2007.

Araken. Comentários ao Código de Processo Civil. Vol VI: arts. 566 a 645. Rio de Janeiro: Forense, 2009.

BESSONE, Darcy. Do contrato: teoria geral. $4^{\mathrm{a}}$ ed. São Paulo: Saraiva, 1997.

Bevilaqua, Clóvis. Código Civil brasileiro: trabalhos relativos à sua elaboração. Vol. I. Rio de Janeiro: Imprensa Nacional, 1917.

Clóvis. Código Civil dos Estados Unidos do Brasil commentado. Vol. I. $5^{\mathrm{a}}$ ed.. Rio de Janeiro: Francisco Alves, 1936.

Bianca, C. Massimo. Diritto Civile: l'obbligazione. Vol. 4. Milano Giuffrè, 1993. 
C. Massimo. Diritto civile: la responsabilità. Vol. 5. Milano: Giuffrè, 1994.

Bortolotti, Fabio. Manuale di Diritto della Distribuzione. Vol. II. Padova: CEDAM, 2007.

BROX, Hans; WALKER, Wolf-Dietrich. Allgemeines Schuldrecht. 34. aktualisierte Auflage, München: C. H. Beck, 2010.

CAMILO JÚNIOR, Ruy Pereira. O contrato de distribuição: uma análise à luz da teoria relacional. Dissertação (mestrado em Direito) apresentada à Faculdade de Direito da Universidade de São Paulo, São Paulo, 2004.

Ruy Pereira. Contrato de distribuição ou concessão mercantil. In JABUR, Gilberto Haddad; PEREIRA JÚNIOR. Antonio Jorge (coord.). Direito dos contratos. São Paulo: Quartier Latin, 2006.

CANARIS, Claus-Wilhelm. A liberdade e a justiça contratual na 'sociedade de direito privado', in António Pinto Monteiro (coord.). Contratos: actualidade e evolução. Porto. Universidade Católica, 1997.

Carvalho de Mendonça, José Xavier. Tratado de Direito Comercial brasileiro. Vol. VI, Parte I. $6^{\text {a }}$ ed. atual. Roberto Carvalho de Mendonça. Rio de Janeiro: Livraria Freitas Bastos, 1960.

CARVAlho De MendonçA, Manuel Inácio. Doutrina prática das obrigações. Tomo II. $4^{\mathrm{a}}$ ed. aum. e atual. José de Aguiar Dias. Rio de Janeiro: Revista Forense, 1956.

Carvalho Santos, João Manuel. Código Civil brasileiro interpretado. Vol. III. 10a ed. Rio de Janeiro: Freitas Bastos, s/d.

João Manoel. Código Civil Brasileiro Interpretado. Vol. XII. 10a ed. Rio de Janeiro: Freitas Bastos, 1977.

João Manuel. Código Civil brasileiro interpretado. Vol. XV. $9^{\mathrm{a}}$ ed. Rio de Janeiro: Freitas Bastos, 1978.

ChAmpaud, Claude. La concession commerciale. Revue trimestrielle de Droit Commercial, Paris, n. 3, p. 451- 504, jul-set. 1963.

COMPARATO, Fábio Konder. Franquia e concessão de venda no Brasil: da consagração ao repúdio? Revista de Direito mercantil, industrial, econômico e financeiro, São Paulo, v. $16, \mathrm{n}^{\mathrm{o}} 18$, p. 53-65, 1975. 
, Fábio Konder. A mora no cumprimento de obrigações contratuais pecuniárias e suas consequências. Revista de Direito Mercantil, Industrial, Econômico e Financeiro, São Paulo, vol. 28, n 74, p. 78-82, 1989.

, Fábio Konder. Estado, empresa e função social. Revista dos Tribunais, São Paulo, no 732, p. 38-46, 1996.

, Fábio Konder. Obrigações de meio, de resultado e de garantia. In FACHIN, Luiz Edson; TEPEDINO, Gustavo José Mendes (coord.). Doutrinas essenciais obrigações e contratos. Vol I. São Paulo: Editora Revista dos Tribunais, 2011.

Costa, Mário Júlio de Almeida. Direito das obrigações. 12ª ed. rev. e at.. Coimbra: Almedina, 2009.

CORDEIRO, António Menezes. A modernização do direito das obrigações - aspectos gerais e reforma da prescrição. ROA, Lisboa, ano 62, n. ${ }^{\circ}$ I, p. 91-110, jan. 2002.

António Menezes. A modernização do direito das obrigações - o direito da perturbação das prestações. ROA, Lisboa, ano 62, n. ${ }^{\circ}$ I, p. 319-345, abr. 2002.

António Menezes. Tratado de Direito Civil português. Vol. 2. Tomo I. Coimbra: Almedina, 2009.

António Menezes. Tratado de Direito Civil. Vol. 5. Coimbra: Almedina, 2011.

Couto e Silva, Clóvis V. do. A Obrigação como processo. Rio de Janeiro: Editora FGV, 2006.

DinIZ, Maria Helena. Curso de Direito civil brasileiro: teoria das obrigações contratuais e extracontratuais. $27^{\mathrm{a}}$ ed. São Paulo: Saraiva, 2011.

Forgioni, Paula A. Interpretação dos negócios empresariais. In FERnANDES, Wanderley (coord.). Contratos empresariais: fundamentos e princípios dos contratos empresariais. São Paulo: Saraiva, 2007.

Paula A. Contrato de distribuição. $2^{\mathrm{a}}$ ed. São Paulo: Editora Revista dos Tribunais, 2008.

Paula A. A evolução do direito comercial brasileiro: da mercancia ao mercado. São Paulo: Editora Revista dos Tribunais, 2009.

Paula A. Teoria geral dos contratos empresariais. São Paulo: Editora Revista dos Tribunais, 2009. 
Paula A. Tullio Ascarelli e os contratos de distribuição. In JUNQUEIRA DE Azevedo, Antonio; Torres, Heleno Taveira; CARbone, Paolo (coord.). Princípios do Novo Código Civil Brasileiro e outros temas - Homenagem a Tullio Ascarelli. $2^{\mathrm{a}}$ ed., São Paulo: Quartier Latin, 2010.

FRADERA, Vera Maria Jacob de. O conceito de inadimplemento fundamental do contrato no artigo 25 da lei internacional sobre vendas, da Convenção de Viena de 1980. Revista da Faculdade de Direito da Universidade Federal do Rio Grande do Sul. Porto Alegre, vol. 11, p. 55-66, 1996.

Freitas, Augusto Teixeira. Esboço do Código Civil. Vol. I. Brasília: Ministério da Justiça, Fundação Universidade de Brasília, 1983.

GALlo, Paolo. Trattado del contratto: I rimedi, la fidúcia, l'apparenza. Tomo III. Torino: UTET, 2010.

GaZalle, Gustavo Kratz. O conceito de mora no Código Civil de 2002. Porto Alegre: Sergio Antonio Fabris, 2008.

Gomes, Orlando. Obrigações. Atual. THEOdORO JÚNIOR, Humberto. $12^{\mathrm{a}}$ ed. $2^{\mathrm{a}}$ tiragem. Rio de Janeiro: Forense, 1999.

Orlando. Contratos. 26 a ed. atual. Antonio Junqueira de Azevedo e Francisco Paulo De Crescenzo Marino. Rio de Janeiro: Forense, 2009.

GRANIERI, Massimiliano. Il tempo e il contratto: Itinerario storico-comparativo sui contratti di durata. Milano: Giuffrè, 2007.

GRAU, Eros Roberto; ForgIONI, Paula A. Restrição à concorrência, autorização legal e seus limites- Lei 8.884, de 1994, e Lei 6.729, de 1979 (“Lei Ferrari”). Revista Trimestral de Direito Público. São Paulo, vol. 21, nº 107, p. 107-121, 1998.

GuERREIRO, José Alexandre Tavares. Aplicação analógica da lei dos revendedores. Revista de Direito mercantil, industrial, econômico e financeiro. São Paulo, v. 22, n 49, p. 34-40, 1983.

José Alexandre Tavares. Comentários sobre: Contrato mercantil. Proposta. Aceitação. Inexistência de manifestação expressa. Art. 1079 do CC. Silêncio circunstanciado que significa manifestação tácita da vontade. Cobrança procedente. Recurso não provido. Revista de Direito mercantil, industrial, econômico e financeiro, São Paulo, v. 23, nº 53, p. 119-122, 1984.

HEMARD, Jean. Les agents commerciaux. Revue trimestrielle de Droit Commercial. Paris, Tome XII, p. 573- 624, p. 1959. 
Herrera, Alicia García. El impacto del tempo em los contratos de franquicia y distribución exclusiva. Valencia: Tirant Lo Blanch, 2008.

IHERING, Rudolf von. Trad. João Vasconcellos. A luta pelo direito. $16^{\mathrm{a}}$ ed. Rio de Janeiro: Forense, 1996.

JUNQUEIRA DE AZEVEDO, Antonio. Negócio jurídico: existência, validade e eficácia. $4^{\mathrm{a}}$ ed. atual. de acordo com o novo Código Civil. São Paulo: Saraiva, 2002.

Antonio. Natureza jurídica do contrato de consórcio. Classificação dos atos jurídicos quanto ao número de partes e quanto aos efeitos. Os contratos relacionais. A boa-fé nos contratos relacionais. Contratos de duração. Alteração das circunstâncias e onerosidade excessiva. Sinalagma e resolução contratual. Resolução parcial do contrato. Função social do contrato (parecer). In Novos estudos e pareceres de direito privado. São Paulo: Saraiva, 2009.

Kroetz, Tarcísio Araújo. As similitudes entre os contratos de agência e representação comercial. In JABUR, Gilberto Haddad; PEREIRA JÚNIOR, Antonio Jorge. Direito dos contratos. São Paulo: Quartier Latin, 2006.

MARINO, Francisco Paulo De Crescenzo. Classificação dos contratos. In JABUR, Gilberto Haddad; Pereira JúNIOR, Antonio Jorge. Direito dos contratos. São Paulo: Quartier Latin, 2006.

Martins-Costa, Judith. A boa-fé no direito privado: sistema e tópica no processo obrigacional. São Paulo: Editora Revista dos Tribunais, 1999.

Judith. Comentários ao novo Código Civil. Vol. V, tomo II: do inadimplemento das obrigações. Coord. Sálvio de Figueiredo Teixeira. Rio de Janeiro: Forense, 2009.

MaNTUCCI, Daniele. L'inadempimento reciproco. Napoli: Edizioni Scientifiche Italiane, 1990.

MaXimiliano, Carlos. Hermenêutica e aplicação do direito. 20. ed. Rio de Janeiro: Forense, 2011.

MongILlo, Roberta. Inadempimento e risoluzione di diritto. Quaderni della Rassegna di diritto civile direta da Pietro Perlingieri. Napoli: Edizioni Scientifiche Italiene, 2012.

Monteiro, António Pinto. Do regime jurídico dos contratos de distribuição comercial. Revista brasileira de Direito comparado, n 22, p. 33-49, $1^{\circ}$ sem. 2002.

António Pinto. Direito comercial: contratos de distribuição comercial. Coimbra: Almedina, 2009. 
Moreira Alves, José Carlos. A unificação do direito privado brasileiro - de Teixeira de Freitas ao Novo Código Civil. In: CARbone, Paolo; JunQueIRa DE Azevedo, Antonio; TôRres, Heleno Taveira. Princípios do Novo Código Civil brasileiro e outros temas: homenagem a Tullio Ascarelli. $2^{\mathrm{a}}$ ed. São Paulo: Quartier Latin, 2010.

NANNI, Giovanni Ettore. Mora. In Lotufo, Renan; NANNI, Giovanni Ettore (coord). Obrigações. São Paulo: Atlas, 2011.

Nanni, Luca; Costanza, Maria; CARnevali, Ugo. Risoluzione per inadempimento. Tomo I, parte 2. Bologna: Zanichelli, 2007.

NERVI, Andrea. I contratti di distribuzione tra causa di scambio e causa associativa. Napoli: Edizioni Scientifiche Italiane, 2011.

PARDOLESI, Roberto. I contratti di distribuzione. Napoli: Editote Jovene, 1979.

PATTI, Salvatore (trad. e pres. a cura di). Codice Civile tedesco. Milano: Giuffrè, 2005.

PEREIRA, Caio Mário da Silva. Instituições de direito civil. Vol. 2. 14. ed. rev. e atual. Regis Fichtner. Rio de Janeiro: Forense, 2010.

, Caio Mário da Silva. Instituições de direito civil. Vol. 3. 14. ed. rev. e atual. Regis Fichtner. Rio de Janeiro: Forense, 2010.

PINTO, Paulo Mota. Interesse contratual negativo e interesse contratual positivo. Vol. I. Coimbra: Editora Coimbra, 2008.

Paulo Mota. Interesse contratual negativo e interesse contratual positivo. Vol. II. Coimbra: Editora Coimbra, 2008.

Pollo, Marcelo. A discriminação de preço nas redes contratuais de distribuição. Dissertação (mestrado em Direito) apresentada à Faculdade de Direito da Universidade Federal do Rio Grande do Sul, Porto Alegre, 2011.

Pontes De MiRAndA, Francisco Cavalcanti. Tratado de direito privado, t. II. $4^{\mathrm{a}}$ ed., São Paulo: Editora Revista dos Tribunais, 1984.

Francisco Cavalcanti. Tratado de direito privado, t. XXII. $3^{\mathrm{a}}$ ed., $2^{\mathrm{a}}$ reimp. São Paulo: Revista dos Tribunais, 1984.

Francisco Cavalcanti. Tratado de direito privado, t. XXIII. $3^{\mathrm{a}}$ ed., $2^{\mathrm{a}}$ reimp. São Paulo: Revista dos Tribunais, 1984. 
Francisco Cavalcanti. Tratado de Direito Privado, t. XXV, $3^{\mathrm{a}}$ ed., $2^{\mathrm{a}}$ reimp. São Paulo: Revista dos Tribunais, 1984.

Francisco Cavalcanti. Tratado de direito privado, t. XXVI. $3^{\mathrm{a}}$ ed., $2^{\mathrm{a}}$ reimp. São Paulo: Revista dos Tribunais, 1984.

PoTHIER, Robert Joseph. Ouvres complètes de Pothier. Tome premier: Traité des obligations. Nouvelle édition. Paris: Chez Thomine et Fortic Libraires, 1821.

Radbruch, Gustav. Filosofia do direito. Trad. L. Cabral de Moncada, $6^{\text {a }}$ ed. Coimbra: Armênio Amado, 1997.

REQUĩ̃o, Rubens. O contrato de concessão de venda com exclusividade. Revista de Direito mercantil, industrial, econômico e financeiro. São Paulo, v. 11, no 7, p. 17-45, 1972.

REQUiÃo, Rubens Edmundo. Os contratos de agência, de representação comercial e o contrato de distribuição. O art. 710 do Código Civil. In BuEnO, J. Hamilton; MARTins, Sandro G. Representação comercial e distribuição: estudos em homenagem ao prof. Rubens Requião. São Paulo: Saraiva, 2006.

Rodrigues, Antônio Coelho. Projeto do Código Civil Brasileiro. 2a ed. Brasília: Ministério da Justiça, 1980.

Roppo, Enzo. O contrato. (Trad. de Ana Maria Coimbra e Manuel Januário Costa e Gomes). Coimbra: Almedina, 1988.

, Vincenzo. Il contratto. $2^{\mathrm{a}}$ ed. Milano: Giuffrè Editore, 2011.

SACCO, Rodolfo; DE NovA, Giorgio. Il contratto. Tomo II. $3^{\text {a }}$ ed. Torino: UTET, 2004.

SCHERKERKEWITZ, Isso Chaitz. Contratos de distribuição e o novo contexto do contrato de representação comercial. São Paulo: Editora Revista dos Tribunais, 2011.

SICCHIERO, Gianluca. La risoluzione per inadempimento. Commentario Artt. 1453-1459. Milano: Giuffrè, 2007.

SiLva, Jorge Cesa Ferreira da. A boa-fé e a violação positiva do contrato. Rio de Janeiro: Renovar, 2002.

SIRENA, Pietro. I contratti di collaborazione. Torino: UTET, 2011. 
SPINOZZI, Michele. La concessione di vendita. In VillanACCI, Gerardo (org). I contratti della distribuzione commerciale. Torino: UTET, 2010.

StAub, Hermann. Le violazioni positive del contratto (Die positiven Vertragsverletzungen). Trad. Giovanni Varanese. Napoli: Edizioni Scientifiche Italiane, 2011.

STEINER, Renata Carlos. Complexidade intra-obrigacional e descumprimento da obrigação: da violação positiva do contrato. Dissertação (Mestrado em Direito) Faculdade de Direito, Universidade Federal do Paraná, Curitiba, 2009.

Tepedino, Gustavo; Barboza, Heloisa Helena; Moraes, Maria Celina Bodin de. Código Civil interpretado conforme a Constituição da República. Vol. II. Rio de Janeiro: Renovar, 2006.

, Gustavo; SchreIBER, Anderson. Código Civil comentado: direito das obrigações - arts. 233 a 420. Vol. 4. São Paulo: Atlas, 2008.

Timm, Luciano Benetti; SABOYA, Lausiane Luz de. O contrato de distribuição no novo Código Civil. Revista Trimestral de Direito Civil, vol. 35, ano 35, p. 75-99, jul./set. 2008.

TheOdORO JÚNIOR, Humberto. Do contrato de agência e distribuição no novo Código Civil. Revista dos Tribunais, São Paulo, vol. 812, ano 92, p. 22-40, jun. 03.

Ureba, Alberto Alonso; San Pedro, Luis Velasco; Ledesma, Carmen Alonso; SÁenz, Joseba Aitor Echevarría; GonZÁleZ, A. Jorge Viera (dir.). Los contratos de distribución. La Ley: Madrid, 2010.

VAsConcelos, Pedro Pais de. Contratos atípicos. Reimpressão da 1. ed. Coimbra: Almedina, 2002.

Venosa, Sílvio de Salvo. Direito civil: contratos em espécie. $11^{\mathrm{a}}$ ed. São Paulo: Atlas, 2011.

VILlELA, João Baptista. Equilíbrio do contrato: os números e a vontade. Revista dos Tribunais, São Paulo, vol. 900, p. 85-121, out. 2010.

Visintini, Giovanna. Trattato della responsabilità contratuale. Vol. I. Padova: Cedam, 2009

ZanetTi, Cristiano de Sousa. Direito contratual contemporâneo: a liberdade contratual e sua fragmentação. São Paulo: Método, 2008. 
Cristiano de Sousa. Built to suit: qualificação e consequências. In BAPTISTA. Luiz Olavo. Construção Civil e Direito. São Paulo: Lex Editora, 2011.

Cristiano de Sousa. A cláusula resolutiva expressa na lei e nos tribunais: o caso do termo de ocupação. In Lotufo, Renan; NANNI, Giovanni Ettore; MARTins, Fernando Rodrigues (coord.). Temas relevantes do direito civil contemporâneo: reflexões sobre os 10 anos do Código Civil. São Paulo: Atlas, 2012.

Cristiano de Sousa. A conservação dos contratos nulos por defeito de forma. São Paulo: Quartier Latin, 2013. 


\section{RELAÇÃO DE JULGADOS CONSULTADOS}

\section{Supremo Tribunal Federal - STF}

1. $\quad R E n^{\circ} 104286-9,1^{\text {a }}$ T., r. Min. Néri da Silveira, j. 22.03.1988.

2. $\quad$ RE no 93.045-1, $1^{\text {a }}$ T., r. Min. Rafael Mayer, j. 08.09.1981.

3. $R E n^{\circ} 19.060,2^{a}$ T., r. Min. Afrânio Antonio da Costa, j. 22.08.1952.

Os julgados foram coletados no sítio 〈http://www.stf.gov.br>.

\section{Superior Tribunal de Justiça - STJ}

1. AgREsp $n^{\circ}$ 102.735, $4^{\mathrm{a}}$ T., r. Min. Luis Felipe Salomão, j. 10.02.2012.

2. REsp n $n^{\circ} 1306667$ e 1306668, $4^{\mathrm{a}}$ T., r. Min. Luis Felipe Salomão, j. 18.12.2012.

3. REsp n ${ }^{\circ}$ 1.255.315, r. Min. Nancy Andrighi, j. 13.09.2011.

4. REsp n $n^{\circ}$ 930.491, $3^{\mathrm{a}}$ T., r. Min. Sidnei Beneti, j. 12.04.2011.

5. REsp $n^{\circ} 654408,4^{a}$ T., r. Min. Fernando Gonçalves, j. 09.02.2010.

6. REsp $n^{0} 789.708,3^{\mathrm{a}}$ T., r. Min. Nancy Andrighi, j. 25.09.2006.

7. REsp no 681100, $3^{\mathrm{a}}$ T., r. Min. Carlos Alberto Menezes Direito, j. 19.06.2006.

$8 \quad$ REsp no 493.659, 4ª T., r. Min. Ruy Rosado de Aguiar, j. 17.06.2003.

9. REsp n ${ }^{\circ}$ 88.565, $3^{\text {a }}$ T., r. Min. Carlos Alberto Menezes Direito, j. 17.11.1997.

10. $\mathrm{AgRg}$ no $\mathrm{Ag} \mathrm{n}^{\circ}$ 43.392, $3^{\mathrm{a}} \mathrm{T}$, r. Min. Eduardo Ribeiro, j. 15.03.1994.

Os julgados foram coletados no sítio <http://www.stj.sp.gov.br〉.

\section{Tribunal de Justiça do Estado de São Paulo - TJSP}

1. $\quad \mathrm{AI} \mathrm{n}^{\mathrm{o}}$ 2030663-44.2013.8.26.0000, 32 Câm. Dir. Priv., r. Der. Luis Fernando Nishi, j. 31.10.2013.

2. Ap. Cív. no 0182861-41.2006.8.26.0002, 14ª Câm. Dir. Priv., r. Carlos Henrique Abrão, j. 28.08.2013.

3. Ap. n. ${ }^{\circ}$ 0013175-98.2012.8.26.0565, $1^{\text {a }}$ Câm. Dir. Priv., r. Des. Paulo Eduardo Razuk, j. 20.08.2013.

4. Ap. $n^{\circ}$ 0081670-51.2009.8.26.0000, 27 Câm. Dir. Priv., r. Des. Morais Pucci, j. 13.08.2013. 
5. Ap. $n^{\circ}$ 0034849-57.2007.8.26.0000, $1^{\text {a }}$ Câm. Dir. Priv., r. Des. Alcides Leopoldo e Silva Júnior, j. 04.12.2012.

6. $\quad$ AI. no 0238119-32.2012.8.26.0000, 25 Câm. Dir. Priv., r. Des. Hugo Crepaldi, j. 28.11.2012.

7. EI. no 0003239-10.2009.8.26.0224, $3^{\text {a }}$ Câm. Dir. Priv., r. Des. Jesus Lofrano, j. 06.11.2012.

8. Ap. n ${ }^{\circ}$ 9230071-67.2008.8.26.0000, 35ª Câm. Dir. Priv., r. Des. Clóvis Castelo, j. 01.10.2012

9. Ap. no 9204284072006826, 30ª Câm. Dir. Priv., r. Des. Andrade Neto, j. 21.09.2011.

10. Ap. n ${ }^{\circ}$ 9195569-78.2003.8.26.0000, 13 ${ }^{\text {a }}$ Câm. Dir. Priv., r. Des. Zélia Maria Antunes Alves, j. 24.08.2011.

11. Ap. no 0220375-64.2002.8.26.0100, 21 a Câm. Dir. Priv., r. Des. Itamar Gaino, j. 02.06.2011.

12. Ap. $\mathrm{n}^{\mathrm{o}}$ 991.07.027294-0, 24 ${ }^{\mathrm{a}}$ Câm. Dir. Priv., r. Des. Salles Vieira, j. 05.05.2011.

13. Ap. $\mathrm{n}^{\circ}$ 0111539-78.2008.8.26.0005, 31 a Câm., r. Des. Adilson de Araújo, j. 19.04.2011.

14. Ap. $n^{\circ}$ 992.05.123294-3, 26 Câm., r. Des. Renato Sartorelli, j. 14.09.2010.

15. Ap. $n^{\circ}$ 994.07.112235-0, $4^{\text {a }}$ Câm. Dir. Priv., r. Des. Teixeira Leite, j. 12.08.2010.

16. Ap. no 990.09.32.8037-0, 37ª Câm. Dir. Priv., r. Des. Roberto Mac Cracken, j. 09.06.2010.

17. Ap. $n^{\circ}$ 991.07.036909-6, $18^{a}$ Câm. Dir. Priv., r. Des. Rodrigo Augusto de Oliveira, j. 24.05.2010.

18. Ap. no 991.09.023753-7, 13ª Câm. Dir. Priv., r. Des. Luiz Sabbato, j. 07.04.2010.

19. Ap. no 994.02.020381-4, 9a Câm. Dir. Priv., r. Des. Antonio Vilenilson, j. 09.03.2010.

20. Ap. $n^{\circ}$ 992.07.041857-7, $32^{\text {a }}$ Câm. Dir. Priv., r. Des. Kioitsi Chicuta, j. 25.02.2010.

21. Ap. no 991.09.026473-9, 37ª Câm. Dir. Priv., r. Des. Tasso Duarte de Melo, j. 24.02.2010.

22. Ap. no 425.847-4/9-00, $1^{\text {a }}$ Câm. Dir. Priv., r. Des. Claudio Lima Bueno de Camargo, j. 07.12.2009.

23. EI. n ${ }^{\circ}$ 991.05.025098-2/50002, 32 ${ }^{\text {a }}$ Câm. Dir. Priv., r. Des. J. B. Franco de Godoi, j. 18.11.2009.

24. Ap. $n^{\circ} 7180353-9,12^{a}$ Câm. Dir. Priv., r. Des. José Reynaldo, j. 21.10.2009.

25. Ap. no 1002419-8, 19a Câm. Dir. Priv., r. Des. Ricardo Negrão, j. 19.10.2009.

26. Ap. $n^{\circ} 4018634600,3^{\text {a }}$ Câm. Dir. Priv., r. Des. Jesus Lofrano, j. 06.10.2009. 
27. Ap. n. ${ }^{\circ}$ 597.055-4/5-00, $3^{\text {a }}$ Câm. Dir. Priv., r. Des. Donegá Morandini, j. 06.10.2009.

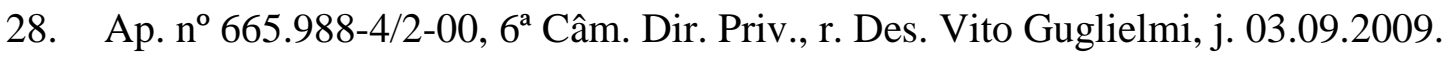

29. Ap. no 1263998-0, 19ª Câm. Dir. Priv., r. Des. Mauro Conti Machado, j. 29.09.2008.

30. Ap. no 398.166-4/0, $4^{\text {a }}$ Câm. Dir. Priv., r. Des. Francisco Loureiro, j. 02.04.2009.

31. Ap. $n^{\circ} 1160584-0 / 0,28^{a}$ Câm. Dir. Priv., r. Des. Júlio Vidal, j. 29.04.2008.

32. Ap. no 995753-0/3, 35ª Câm. Dir. Priv., r. Des. Clovis Castelo, j. 17.03.2008.

33. Ap. nº 186.066-4/3-00, 5 Câm. Dir. Priv., r. Des. Oscarlino Moeller, j. 12.03.2008.

34. Ap. $n^{\circ}$ 7.029.588-8, $23^{\text {a }}$ Câm. Dir. Priv., r. Des. Rizzatto Nunes, j. 05.03.2008.

35. Ap. no 7142928-2, 16 ${ }^{\text {a }}$ Câm. Dir. Priv., r. Des. Maury Angelo Bottesini, j. 25.02.2008.

36. Ap. $n^{\circ}$ 108284-0/0, 36a Câm., r. Des. Arantes Theodoro, j. 12.07.2007.

37. Ap. $n^{\circ}$ 1.237.997-0, 12 $2^{\text {a }}$ Câm. Dir. Priv., r. Des. Rui Cascaldi, j. 11.07.2007.

38. Ap. no 437.879-4/7-00, 6ª Câm. Dir. Priv., r. Des. Vito Guglielmi, j. 29.03.2007.

39. Ap. no 266.683-4/1-00, $1^{\text {a }}$ Câm. Dir. Priv., r. Des. Laerte Nordi, j. 09.03.2004.

40. Ap. $n^{\circ}$ 137.106-4/3, $2^{\text {a }}$ Câm. Dir. Priv., r. Des. Maia da Cunha, j. 20.05.2003.

41. Ap. $n^{\circ}$ 130.705-4/6, $7^{\text {a }}$ Câm. Dir. Priv., r. Des. Souza Lima, j. 19.02.2003.

42. Ap. $n^{\circ}$ 127.133-4/8, $2^{\text {a }}$ Câm. Dir. Priv., r. Des. Maia da Cunha, j. 11.06.2002.

43. Ap. $n^{\circ}$ 80.338-4/2, $1^{\text {a }}$ Câm. Dir. Priv., r. Des. Guimarães e Souza, j. 01.06.1999.

Os julgados foram coletados no sítio <http://www.tj.sp.gov.br〉.

\section{Tribunal de Alçada Civil do Estado de São Paulo - $1^{\circ}$ TACivSP}

1. Ap. $n^{\circ}$ 768.938-3, 2 $2^{\text {a }}$ Câm., r. Juiz Cyro Bonilha, j. 18.08.1999.

2. Ap. $n^{\circ}$ 775.233-4, $3^{\text {a }}$ Câm., r. Juiz. Soares de Mello, j. 23.02.1999.

Os julgados foram coletados no sítio <http://www.tj.sp.gov.br>.

\section{Outros}

1. TJSC, Ap. no 2007.033186-5, 3ª Câm. Dir. Com., r. Des. Domingos Paludo, j. 02.07.2010.

2. TJPR, Ap. n 456512-2, 6ª Câm. Cível, r. Des. Jefferson Alberto Johnsson, j. 11.11.2008.

3. TJPR, Ap. nº 0139236-7, $8^{\text {a }}$ Câm., r. Des. Campos Marques, j. 20.08.2003.

4. TJPR, Ap. Civ. no 0124804-2, $1^{\text {a }}$ Câm. Civ., r. Des. Pacheco Rocha, j. 01.10.2002. 
5. TJRS, Ap. no 70002672095, 9ª Câm., r. Des. Ana Lúcia Carvalho Pinto Vieira Rebout, j. 30.04.2003.

Os julgados foram coletados no sítio dos respectivos Tribunais. 


\title{
FONTES PRIMÁRIAS
}

\section{Direito Ibérico Antigo}

\author{
Código Filipino ou Ordenações e Leis do Reino de Portugal ${ }^{294}$ \\ Trecho extraído de Código Filipino ou Ordenações e Leis do Reino de Portugal, \\ Livro IV, Título L, 1 [edição fac-símile da 14ª edição, de 1870, com introdução e \\ comentários de Cândido Mendes de Almeida], Brasília, Senado Federal, 2004.
}

Fonte: Ordenações Filipinas, Livro IV, Título L, 1.

Título: Do emprestido, que se chama mutuo.

Texto: E esta cousa assi emprestada deve tornar o devedor ao tempo e prazo, que lhe for posto, e não sendo declarado tempo, cada vez que o acredor lha pedir, e desse tempo fica constituído em mora. O qual se não deve entender logo, porque seria vão e frustatorio o beneficio, se logo se houvesse de pedir o que se empresta; polo que se darão ao devedor dez dias de spaço, como se dao ao que se obriga a pagar alguma cousa sem declaração de tempo, ou dilação, ou mais spaço, se ao Julgador parecer assi, segundo a qualidade das pessoas, tempo e lugar.

\section{Direito Latino-Americano}

\section{Argentina}

\section{Código Civil}

Art. 508. El deudor es igualmente responsable por los daños e intereses que su morosidad causar al acreedor en el cumplimiento de la obligación.

Art. 509. En las obligaciones a plazo, la mora se produce por su solo vencimiento.

Si el plazo no estuviere expresamente convenido, pero resultare tácitamente de la naturaleza y circunstancias de la obligación, el acreedor deberá interpelar al deudor para constituirlo en mora.

Si no hubiere plazo, el juez a pedido de parte, lo fijará en procedimiento sumario, a menos que el acreedor opte por acumular las acciones de fijación de plazo y de cumplimiento, en

${ }^{294}$ Vale anotar que foi mantida a grafia do português antigo. 
cuyo caso el deudor quedará constituido en mora en la fecha indicada por la sentencia para el cumplimiento de la obligación.

Para eximirse de las responsabilidades derivadas de la mora, el deudor debe probar que no le es imputable.

\section{Brasil}

Código Comercial de 1850

Art. 133 Omitindo-se na redação do contrato cláusulas necessárias à sua execução, deverá presumir-se que as partes se sujeitaram ao que é de uso e prática em tais casos entre os comerciantes, no lugar da execução do contrato.

Art. 202 - Quando o vendedor deixa de entregar a coisa vendida no tempo aprazado, o comprador tem opção, ou de rescindir o contrato, ou de demandar o seu cumprimento com os danos da mora; salvo os casos fortuitos ou de força maior.

Art. 204. Se o comprador sem justa causa recusar receber a coisa vendida, ou deixar de a receber no tempo ajustado, terá o vendedor ação para rescindir o contrato, ou demandar o comprador pelo preço com os juros legais da mora; devendo, no segundo caso, requerer depósito judicial dos objetos vendidos por conta e risco de quem pertencer.

\section{Esboço de Código Civil}

Trecho extraído de Freitas, Augusto Teixeira. Esboço do Código Civil. Brasília: Ministério da Justiça, Fundação Universidade de Brasília, 1983.

Art. 1.070. Ficará constituído em mora o devedor, que não fizer o pagamento, e o credor que o não quiser receber, em tempo oportuno.

Projeto de Código Civil de 1881

Trecho Extraído de FELÍ́CIO DOs SAnTos, Joaquim. Projeto do Código Civil Brazileiro e Comentário. Tomo I. Rio de Janeiro: H. Laemmert \& C., 1884.

Art. 375. O devedor se diz constituído em móra: 
1. ${ }^{\text {- }}$ - Quando não cumprio a obrigação no prazo marcado, ou subentendido pela natureza da mesma.

2. ${ }^{\circ}$ Nos casos especialmente marcados na lei.

3. ${ }^{\circ} \mathrm{Na}$ falta do prazo ou disposição legal, depois de protesto ou intimação judicial.

\title{
Projeto de Código Civil de 1893
}

Trecho Extraído de Rodrigues, Antônio Coelho. Projeto do Código Civil Brasileiro. $2^{\mathrm{a}}$ ed. Brasília: Ministério da Justiça, 1980.

Art. 414. O devedor, que não satisfaz a obrigação dentro do prazo estipulado para cumprila, fica, pelo mesmo facto, constituído em mora.

\author{
Projeto Primitivo do Código Civil de Clovis Bevilaqua \\ Trecho extraído de Bevilaqua, Clóvis. Código Civil brasileiro: trabalhos relativos \\ à sua elaboração. Vol. I. Rio de Janeiro: Imprensa Nacional, 1917
}

Art. 1.100. Ficarão constituídos em mora o devedor que não effectuar o pagamento, e o credor que não o quizer receber em tempo opportuno.

\section{Código Civil de 1916}

Art. 863. O credor de coisa certa não pode ser obrigado a receber outra, ainda que mais valiosa.

Art. 955. Considera-se em mora o devedor que não efetuar o pagamento, e o credor que não quiser receber no tempo, lugar e forma convencionado.

Art. 1.056. Não cumprindo a obrigação, ou deixando de cumpri-la pelo modo e no tempo devidos, responde o devedor por perdas e danos.

\section{Anteprojeto da Parte Geral do Código de Obrigações de 1941}

Art. 281. Considera-se em mora o devedor que não efetue o pagamento e o credor que o recuse, no tempo, lugar e forma que a convenção ou a lei estabelecerem. 
Anteprojeto de Código de Obrigações de 1963

Art. 188. Considera-se em mora o devedor que não efetue o pagamento, e o credor que recuse, no tempo, lugar e forma, o que a convenção ou a lei estabelecer.

\section{Projeto de Código de Obrigações de 1965}

Art. 179. Considera-se em mora o devedor que não efetue o pagamento, e o credor que o recuse, no tempo, lugar e modo, que a convenção ou a lei estabelecer.

\section{Projeto de Código de Civil de 1975}

Art. 392. Considera-se em mora o devedor que não efetuar o pagamento, e o credor que o não quiser receber no tempo, lugar e forma que a lei ou a convenção estabelecer.

\section{Código Civil de 2002}

Art. 104. A validade do negócio jurídico requer:

I - agente capaz;

II - objeto lícito, possível, determinado ou determinável;

III - forma prescrita ou não defesa em lei.

Art. 128. Sobrevindo a condição resolutiva, extingue-se, para todos os efeitos, o direito a que ela se opõe; mas, se aposta a um negócio de execução continuada ou periódica, a sua realização, salvo disposição em contrário, não tem eficácia quanto aos atos já praticados, desde que compatíveis com a natureza da condição pendente e conforme aos ditames de boa-fé.

Art. 234. Se, no caso do artigo antecedente, a coisa se perder, sem culpa do devedor, antes da tradição, ou pendente a condição suspensiva, fica resolvida a obrigação para ambas as partes; se a perda resultar de culpa do devedor, responderá este pelo equivalente e mais perdas e danos.

Art. 235. Deteriorada a coisa, não sendo o devedor culpado, poderá o credor resolver a obrigação, ou aceitar a coisa, abatido de seu preço o valor que perdeu. 
Art. 236. Sendo culpado o devedor, poderá o credor exigir o equivalente, ou aceitar a coisa no estado em que se acha, com direito a reclamar, em um ou em outro caso, indenização das perdas e danos.

Art. 243. A coisa incerta será indicada, ao menos, pelo gênero e pela quantidade.

Art. 244. Nas coisas determinadas pelo gênero e pela quantidade, a escolha pertence ao devedor, se o contrário não resultar do título da obrigação; mas não poderá dar a coisa pior, nem será obrigado a prestar a melhor.

Art. 245. Cientificado da escolha o credor, vigorará o disposto na Seção antecedente.

Art. 246. Antes da escolha, não poderá o devedor alegar perda ou deterioração da coisa, ainda que por força maior ou caso fortuito.

Art. 247. Incorre na obrigação de indenizar perdas e danos o devedor que recusar a prestação a ele só imposta, ou só por ele exequiível.

Art. 248. Se a prestação do fato tornar-se impossível sem culpa do devedor, resolver-se-á a obrigação; se por culpa dele, responderá por perdas e danos.

Art. 249. Se o fato puder ser executado por terceiro, será livre ao credor mandá-lo executar à custa do devedor, havendo recusa ou mora deste, sem prejuízo da indenização cabível.

Parágrafo único. Em caso de urgência, pode o credor, independentemente de autorização judicial, executar ou mandar executar o fato, sendo depois ressarcido.

Art. 250. Extingue-se a obrigação de não fazer, desde que, sem culpa do devedor, se lhe torne impossível abster-se do ato, que se obrigou a não praticar.

Art. 251. Praticado pelo devedor o ato, a cuja abstenção se obrigara, o credor pode exigir dele que o desfaça, sob pena de se desfazer à sua custa, ressarcindo o culpado perdas e danos. 
Parágrafo único. Em caso de urgência, poderá o credor desfazer ou mandar desfazer, independentemente de autorização judicial, sem prejuízo do ressarcimento devido.

Art. 313. O credor não é obrigado a receber prestação diversa da que lhe é devida, ainda que mais valiosa.

Art. 389. Não cumprida a obrigação, responde o devedor por perdas e danos, mais juros e atualização monetária segundo índices oficiais regularmente estabelecidos, e honorários de advogado.

Art. 390. Nas obrigações negativas o devedor é havido por inadimplente desde o dia em que executou o ato de que se devia abster.

Art. 393. O devedor não responde pelos prejuízos resultantes de caso fortuito ou força maior, se expressamente não se houver por eles responsabilizado.

Parágrafo único. O caso fortuito ou de força maior verifica-se no fato necessário, cujos efeitos não era possível evitar ou impedir.

Art. 394. Considera-se em mora o devedor que não efetuar o pagamento e o credor que não quiser recebê-lo no tempo, lugar e forma que a lei ou a convenção estabelecer.

Art. 395. Responde o devedor pelos prejuízos a que sua mora der causa, mais juros, atualização dos valores monetários segundo índices oficiais regularmente estabelecidos, e honorários de advogado.

Parágrafo único. Se a prestação, devido à mora, se tornar inútil ao credor, este poderá enjeitá-la, e exigir a satisfação das perdas e danos.

Art. 396. Não havendo fato ou omissão imputável ao devedor, não incorre este em mora.

Art. 397. O inadimplemento da obrigação, positiva e líquida, no seu termo, constitui de pleno direito em mora o devedor. 
Art. 399. O devedor em mora responde pela impossibilidade da prestação, embora essa impossibilidade resulte de caso fortuito ou de força maior, se estes ocorrerem durante o atraso; salvo se provar isenção de culpa, ou que o dano sobreviria ainda quando a obrigação fosse oportunamente desempenhada.

Art. 400. A mora do credor subtrai o devedor isento de dolo à responsabilidade pela conservação da coisa, obriga o credor a ressarcir as despesas empregadas em conservá-la, e sujeita-o a recebê-la pela estimação mais favorável ao devedor, se o seu valor oscilar entre o dia estabelecido para o pagamento e o da sua efetivação.

Art. 401. Purga-se a mora:

I - por parte do devedor, oferecendo este a prestação mais a importância dos prejuízos decorrentes do dia da oferta;

II - por parte do credor, oferecendo-se este a receber o pagamento e sujeitando-se aos efeitos da mora até a mesma data.

Art. 402. Salvo as exceções expressamente previstas em lei, as perdas e danos devidas ao credor abrangem, além do que ele efetivamente perdeu, o que razoavelmente deixou de lucrar.

Art. 403. Ainda que a inexecução resulte de dolo do devedor, as perdas e danos só incluem os prejuízos efetivos e os lucros cessantes por efeito dela direto e imediato, sem prejuízo do disposto na lei processual

Art. 422. Os contratantes são obrigados a guardar, assim na conclusão do contrato, como em sua execução, os princípios de probidade e boa-fé.

Art. 423. Quando houver no contrato de adesão cláusulas ambíguas ou contraditórias, dever-se-á adotar a interpretação mais favorável ao aderente.

Art. 424. Nos contratos de adesão, são nulas as cláusulas que estipulem a renúncia antecipada do aderente a direito resultante da natureza do negócio. 
Art. 474. A cláusula resolutiva expressa opera de pleno direito; a tácita depende de interpelação judicial.

Art. 475. A parte lesada pelo inadimplemento pode pedir a resolução do contrato, se não preferir exigir-lhe o cumprimento, cabendo, em qualquer dos casos, indenização por perdas e danos.

Art. 476. Nos contratos bilaterais, nenhum dos contratantes, antes de cumprida a sua obrigação, pode exigir o implemento da do outro.

Art. 534. Pelo contrato estimatório, o consignante entrega bens móveis ao consignatário, que fica autorizado a vendê-los, pagando àquele o preço ajustado, salvo se preferir, no prazo estabelecido, restituir-lhe a coisa consignada.

Art. 535. O consignatário não se exonera da obrigação de pagar o preço, se a restituição da coisa, em sua integridade, se tornar impossível, ainda que por fato a ele não imputável.

Art. 536. A coisa consignada não pode ser objeto de penhora ou seqüestro pelos credores do consignatário, enquanto não pago integralmente o preço.

Art. 537. O consignante não pode dispor da coisa antes de lhe ser restituída ou de lhe ser comunicada a restituição.

Art. 693. O contrato de comissão tem por objeto a aquisição ou a venda de bens pelo comissário, em seu próprio nome, à conta do comitente.

Art. 694. O comissário fica diretamente obrigado para com as pessoas com quem contratar, sem que estas tenham ação contra o comitente, nem este contra elas, salvo se o comissário ceder seus direitos a qualquer das partes.

Art. 695. O comissário é obrigado a agir de conformidade com as ordens e instruções do comitente, devendo, na falta destas, não podendo pedi-las a tempo, proceder segundo os usos em casos semelhantes. 
Parágrafo único. Ter-se-ão por justificados os atos do comissário, se deles houver resultado vantagem para o comitente, e ainda no caso em que, não admitindo demora a realização do negócio, o comissário agiu de acordo com os usos.

Art. 696. No desempenho das suas incumbências o comissário é obrigado a agir com cuidado e diligência, não só para evitar qualquer prejuízo ao comitente, mas ainda para lhe proporcionar o lucro que razoavelmente se podia esperar do negócio.

Parágrafo único. Responderá o comissário, salvo motivo de força maior, por qualquer prejuízo que, por ação ou omissão, ocasionar ao comitente.

Art. 697. O comissário não responde pela insolvência das pessoas com quem tratar, exceto em caso de culpa e no do artigo seguinte.

Art. 698. Se do contrato de comissão constar a cláusula del credere, responderá o comissário solidariamente com as pessoas com que houver tratado em nome do comitente, caso em que, salvo estipulação em contrário, o comissário tem direito a remuneração mais elevada, para compensar o ônus assumido.

Art. 699. Presume-se o comissário autorizado a conceder dilação do prazo para pagamento, na conformidade dos usos do lugar onde se realizar o negócio, se não houver instruções diversas do comitente.

Art. 700. Se houver instruções do comitente proibindo prorrogação de prazos para pagamento, ou se esta não for conforme os usos locais, poderá o comitente exigir que o comissário pague incontinenti ou responda pelas conseqüências da dilação concedida, procedendo-se de igual modo se o comissário não der ciência ao comitente dos prazos concedidos e de quem é seu beneficiário.

Art. 701. Não estipulada a remuneração devida ao comissário, será ela arbitrada segundo os usos correntes no lugar.

Art. 702. No caso de morte do comissário, ou, quando, por motivo de força maior, não puder concluir o negócio, será devida pelo comitente uma remuneração proporcional aos trabalhos realizados. 
Art. 703. Ainda que tenha dado motivo à dispensa, terá o comissário direito a ser remunerado pelos serviços úteis prestados ao comitente, ressalvado a este o direito de exigir daquele os prejuízos sofridos.

Art. 704. Salvo disposição em contrário, pode o comitente, a qualquer tempo, alterar as instruções dadas ao comissário, entendendo-se por elas regidos também os negócios pendentes.

Art. 705. Se o comissário for despedido sem justa causa, terá direito a ser remunerado pelos trabalhos prestados, bem como a ser ressarcido pelas perdas e danos resultantes de sua dispensa.

Art. 706. O comitente e o comissário são obrigados a pagar juros um ao outro; o primeiro pelo que o comissário houver adiantado para cumprimento de suas ordens; e o segundo pela mora na entrega dos fundos que pertencerem ao comitente.

Art. 707. O crédito do comissário, relativo a comissões e despesas feitas, goza de privilégio geral, no caso de falência ou insolvência do comitente.

Art. 708. Para reembolso das despesas feitas, bem como para recebimento das comissões devidas, tem o comissário direito de retenção sobre os bens e valores em seu poder em virtude da comissão.

Art. 709. São aplicáveis à comissão, no que couber, as regras sobre mandato.

Art. 710. Pelo contrato de agência, uma pessoa assume, em caráter não eventual e sem vínculos de dependência, a obrigação de promover, à conta de outra, mediante retribuição, a realização de certos negócios, em zona determinada, caracterizando-se a distribuição quando o agente tiver à sua disposição a coisa a ser negociada.

Parágrafo único. O proponente pode conferir poderes ao agente para que este o represente na conclusão dos contratos. 
Art. 711. Salvo ajuste, o proponente não pode constituir, ao mesmo tempo, mais de um agente, na mesma zona, com idêntica incumbência; nem pode o agente assumir o encargo de nela tratar de negócios do mesmo gênero, à conta de outros proponentes.

Art. 712. O agente, no desempenho que lhe foi cometido, deve agir com toda diligência, atendo-se às instruções recebidas do proponente.

Art. 713. Salvo estipulação diversa, todas as despesas com a agência ou distribuição correm a cargo do agente ou distribuidor.

Art. 714. Salvo ajuste, o agente ou distribuidor terá direito à remuneração correspondente aos negócios concluídos dentro de sua zona, ainda que sem a sua interferência.

Art. 715. O agente ou distribuidor tem direito à indenização se o proponente, sem justa causa, cessar o atendimento das propostas ou reduzi-lo tanto que se torna antieconômica a continuação do contrato.

Art. 716. A remuneração será devida ao agente também quando o negócio deixar de ser realizado por fato imputável ao proponente.

Art. 717. Ainda que dispensado por justa causa, terá o agente direito a ser remunerado pelos serviços úteis prestados ao proponente, sem embargo de haver este perdas e danos pelos prejuízos sofridos.

Art. 718. Se a dispensa se der sem culpa do agente, terá ele direito à remuneração até então devida, inclusive sobre os negócios pendentes, além das indenizações previstas em lei especial.

Art. 719. Se o agente não puder continuar o trabalho por motivo de força maior, terá direito à remuneração correspondente aos serviços realizados, cabendo esse direito aos herdeiros no caso de morte. 
Art. 720. Se o contrato for por tempo indeterminado, qualquer das partes poderá resolvê-lo, mediante aviso prévio de noventa dias, desde que transcorrido prazo compatível com a natureza e o vulto do investimento exigido do agente.

Parágrafo único. No caso de divergência entre as partes, o juiz decidirá da razoabilidade do prazo e do valor devido.

Art. 721. Aplicam-se ao contrato de agência e distribuição, no que couber, as regras concernentes ao mandato e à comissão e as constantes de lei especial.

\section{Código de Processo Civil}

Art. 461. Na ação que tenha por objeto o cumprimento de obrigação de fazer ou não fazer, o juiz concederá a tutela específica da obrigação ou, se procedente o pedido, determinará providências que assegurem o resultado prático equivalente ao do adimplemento.

Art. 621. O devedor de obrigação de entrega de coisa certa, constante de título executivo extrajudicial, será citado para, dentro de 10 (dez) dias, satisfazer a obrigação ou, seguro o juízo (art. 737, II), apresentar embargos.

Parágrafo único. O juiz, ao despachar a inicial, poderá fixar multa por dia de atraso no cumprimento da obrigação, ficando o respectivo valor sujeito a alteração, caso se revele insuficiente ou excessivo.

Art. 625. Não sendo a coisa entregue ou depositada, nem admitidos embargos suspensivos da execução, expedir-se-á, em favor do credor, mandado de imissão na posse ou de busca e apreensão, conforme se tratar de imóvel ou de móvel.

Art. 627. O credor tem direito a receber, além de perdas e danos, o valor da coisa, quando esta não lhe for entregue, se deteriorou, não for encontrada ou não for reclamada do poder de terceiro adquirente.

$\S 1^{\circ}$ Não constando do título o valor da coisa, ou sendo impossível a sua avaliação, o exequente far-lhe-á a estimativa, sujeitando-se ao arbitramento judicial.

$\S 2^{\circ}$ Serão apurados em liquidação o valor da coisa e os prejuízos. 
Art. 632. Quando o objeto da execução for obrigação de fazer, o devedor será citado para satisfazê-la no prazo que o juiz Ihe assinar, se outro não estiver determinado no título executivo.

Art. 633. Se, no prazo fixado, o devedor não satisfizer a obrigação, é lícito ao credor, nos próprios autos do processo, requerer que ela seja executada à custa do devedor, ou haver perdas e danos; caso em que ela se converte em indenização.

Parágrafo único. O valor das perdas e danos será apurado em liquidação, seguindo-se a execução para cobrança de quantia certa.

Art. 634. Se o fato puder ser prestado por terceiro, é lícito ao juiz, a requerimento do exeqüente, decidir que aquele o realize à custa do executado.

Parágrafo único. $\mathrm{O}$ exeqüente adiantará as quantias previstas na proposta que, ouvidas as partes, o juiz houver aprovado.

Art. 638. Nas obrigações de fazer, quando for convencionado que o devedor a faça pessoalmente, o credor poderá requerer ao juiz que Ihe assine prazo para cumpri-la.

Parágrafo único. Havendo recusa ou mora do devedor, a obrigação pessoal do devedor converter-se-á em perdas e danos, aplicando-se outrossim o disposto no art. 633.

Art. 642. Se o devedor praticou o ato, a cuja abstenção estava obrigado pela lei ou pelo contrato, o credor requererá ao juiz que Ihe assine prazo para desfazê-lo.

Art. 643. Havendo recusa ou mora do devedor, o credor requererá ao juiz que mande desfazer o ato à sua custa, respondendo o devedor por perdas e danos.

Parágrafo único. Não sendo possível desfazer-se o ato, a obrigação resolve-se em perdas e danos.

Art. 644. A sentença relativa a obrigação de fazer ou não fazer cumpre-se de acordo com o art. 461, observando-se, subsidiariamente, o disposto neste Capítulo.

Art. 646. A execução por quantia certa tem por objeto expropriar bens do devedor, a fim de satisfazer o direito do credor (art. 591). 
Art. 651. Antes de adjudicados ou alienados os bens, pode o executado, a todo tempo, remir a execução, pagando ou consignando a importância atualizada da dívida, mais juros, custas e honorários advocatícios.

\section{Lei $n^{\circ} 4.886 / 65$}

Art. $1^{\circ}$ Exerce a representação comercial autônoma a pessoa jurídica ou a pessoa física, sem relação de emprêgo, que desempenha, em caráter não eventual por conta de uma ou mais pessoas, a mediação para a realização de negócios mercantis, agenciando propostas ou pedidos, para, transmití-los aos representados, praticando ou não atos relacionados com a execução dos negócios.

\section{Lei $n^{\circ} 6.729 / 79$}

Art. $5^{\circ}$ São inerentes à concessão:

I - área operacional de responsabilidade do concessionário para o exercício de suas atividades;

II - distâncias mínimas entre estabelecimentos de concessionários da mesma rede, fixadas segundo critérios de potencial de mercado.

$\S 1^{\circ} \mathrm{A}$ área poderá conter mais de um concessionário da mesma rede.

$\S 2^{\circ} \mathrm{O}$ concessionário obriga-se à comercialização de veículos automotores, implementos, componentes e máquinas agrícolas, de via terrestre, e à prestação de serviços inerentes aos mesmos, nas condições estabelecidas no contrato de concessão comercial, sendo-lhe defesa a prática dessas atividades, diretamente ou por intermédio de prepostos, fora de sua área demarcada.

$\S 3^{\circ} \mathrm{O}$ consumidor, à sua livre escolha, poderá proceder à aquisição dos bens e serviços a que se refere esta lei em qualquer concessionário.

$\S 4^{\circ}$ Em convenção de marca serão fixados os critérios e as condições para ressarcimento da concessionária ou serviço autorizado que prestar os serviços de manutenção obrigatórios pela garantia do fabricante, vedada qualquer disposição de limite à faculdade prevista no parágrafo anterior.

Art. $7^{\circ}$ Compreende-se na concessão a quota de veículos automotores assim estabelecida: I - o concedente estimará sua produção destinada ao mercado interno para o período anual subsequiente, por produto diferenciado e consoante a expectativa de mercado da marca; 
II - a quota corresponderá a uma parte da produção estimada, compondo-se de produtos diferenciados, e independentes entre si, inclusive quanto às respectivas quantidades; Ill - o concedente e o concessionário ajustarão a quota que a este caberá, consoante a respectiva capacidade empresarial e desempenho de comercialização e conforme a capacidade do mercado de sua área demarcada.

$\S 1^{\circ} \mathrm{O}$ ajuste da quota independe dos estoques mantidos pelo concessionário, nos termos da presente Lei.

$\S 2^{\circ}$ A quota será revista anualmente, podendo reajustar-se conforme os elementos constantes dos incisos deste artigo e a rotatividade dos estoques do concessionário.

$\S 3^{\circ} \mathrm{Em}$ seu atendimento, a quota de veículos automotores comportará ajustamentos decorrentes de eventual diferença entre a produção efetiva e a produção estimada.

$\S 4^{\circ}$ É facultado incluir na quota os veículos automotores comercializados através das modalidades auxiliares de venda a que se refere o art. $3^{\circ}, \S 3^{\circ}$.

Art. 10. O concedente poderá exigir do concessionário a manutenção de estoque proporcional à rotatividade dos produtos novos, objeto da concessão, e adequado à natureza dos clientes do estabelecimento, respeitados os limites prescritos nos $\S \S 1^{\circ}$ e $2^{\circ}$ seguintes.

$\S 1^{\circ}$ É facultado ao concessionário limitar seu estoque:

a) de veículos automotores em geral a sessenta e cinco por cento e de caminhões em particular a trinta por cento da atribuição mensal das respectivas quotas anuais por produto diferenciado, ressalvado o disposto na alínea b seguinte;

b) de tratores, a quatro por cento da quota anual de cada produto diferenciado;

c) de implementos, a cinco por cento do valor das respectivas vendas que houver efetuado nos últimos doze meses;

d) de componentes, o valor que não ultrapasse o preço pelo qual adquiriu aqueles que vendeu a varejo nos últimos três meses.

$\S 2^{\circ}$ Para efeito dos limites previstos no parágrafo anterior, em suas alíneas a e b a cada seis meses será comparada a quota com a realidade do mercado do concessionário, segundo a comercialização por este efetuada, reduzindo-se os referidos limites na proporção de eventual diferença a menor das vendas em relação às atribuições mensais, consoante os critérios estipulados entre produtor e sua rede de distribuição.

$\S 3^{\circ} \mathrm{O}$ concedente reparará o concessionário do valor do estoque de componentes que alterar ou deixar de fornecer, mediante sua recompra por preço atualizado à rede de 
distribuição ou substituição pelo sucedâneo ou por outros indicados pelo concessionário, devendo a reparação dar-se em um ano da ocorrência do fato.

Art. 12. O concessionário só poderá realizar a venda de veículos automotores novos diretamente a consumidor, vedada a comercialização para fins de revenda.

Parágrafo único. Ficam excluídas da disposição deste artigo:

a) operações entre concessionários da mesma rede de distribuição que, em relação à respectiva quota, não ultrapassem quinze por cento quanto a caminhões e dez por cento quanto aos demais veículos automotores;

b) vendas que o concessionário destinar ao mercado externo.

Art. 20. A concessão comercial entre produtores e distribuidores de veículos automotores será ajustada em contrato que obedecerá forma escrita padronizada para cada marca e especificará produtos, área demarcada, distância mínima e quota de veículos automotores, bem como as condições relativas a requisitos financeiros, organização administrativa e contábil, capacidade técnica, instalações, equipamentos e mão-de-obra especializada do concessionário.

\section{Lei $n^{\circ} 12.529 / 11$}

Art. 36. Constituem infração da ordem econômica, independentemente de culpa, os atos sob qualquer forma manifestados, que tenham por objeto ou possam produzir os seguintes efeitos, ainda que não sejam alcançados:

(...)

$\S 3^{\underline{o}}$ As seguintes condutas, além de outras, na medida em que configurem hipótese prevista no caput deste artigo e seus incisos, caracterizam infração da ordem econômica:

(...)

IX - impor, no comércio de bens ou serviços, a distribuidores, varejistas e representantes preços de revenda, descontos, condições de pagamento, quantidades mínimas ou máximas, margem de lucro ou quaisquer outras condições de comercialização relativos a negócios destes com terceiros;

(...)

XVIII - subordinar a venda de um bem à aquisição de outro ou à utilização de um serviço, ou subordinar a prestação de um serviço à utilização de outro ou à aquisição de um bem; 


\title{
Chile
}

\section{Código Civil}

Art. 1.551. El deudor está en mora,

1. Cuando no ha cumplido la obligación dentro del término estipulado, salvo que la ley en casos especiales exija que se requiera al deudor para constituirle en mora;

2. Cuando la cosa no ha podido ser dada o ejecutada sino dentro de cierto espacio de tiempo, y el deudor lo ha dejado pasar sin darla o ejecutarla;

3. En los demás casos, cuando el deudor ha sido judicialmente reconvenido por el acreedor.

\section{Direito Europeu}

\author{
Alemanha \\ Código Civil \\ Dada a maior proximidade com a língua portuguesa, inclui-se também o texto da \\ tradução do BGB em italiano, qual seja PATTI, Salvatore (trad. e pres. a cura di). \\ Codice Civile tedesco. Milano: Giuffrè, 2005.
}

§ 280 Schadensersatz wegen Pflichtverletzung

(1) Verletzt der Schuldner eine Pflicht aus dem Schuldverhältnis, so kann der Gläubiger Ersatz des hierdurch entstehenden Schadens verlangen. Dies gilt nicht, wenn der Schuldner die Pflichtverletzung nicht zu vertreten hat.

(2) Schadensersatz wegen Verzögerung der Leistung kann der Gläubiger nur unter der zusätzlichen Voraussetzung des $§ 286$ verlangen.

(3) Schadensersatz statt der Leistung kann der Gläubiger nur unter den zusätzlichen Voraussetzungen des $\S 281$, des $\S 282$ oder des $\S 283$ verlangen.

$\S 280$ Risarcimento del danno per la violazione di um obbligo

(1) Se il debitore viola un obbligo derivante dal rapporto obbligatorio, il creditore può pretendere il risarcimento del danno che ne è derivato. Ciò non vale se la violazione dell'obbligo non è imputabile al debitore 
(2) Il creditore può pretendere il risarcimento del danno per ritardo della prestazione solamente se sussistono gli ulteriori presupposti del §286.

(3) Il creditore può pretendere il risarcimento del danno in luogo della prestazione solamente se sussistono gli ulteriri pressuposti del $§ 281$, del $§ 282$ o del $§ 283$.

$\S 281$ Schadensersatz statt der Leistung wegen nicht oder nicht wie geschuldet erbrachter Leistung

(1) Soweit der Schuldner die fällige Leistung nicht oder nicht wie geschuldet erbringt, kann der Gläubiger unter den Voraussetzungen des § 280 Abs. 1 Schadensersatz statt der Leistung verlangen, wenn er dem Schuldner erfolglos eine angemessene Frist zur Leistung oder Nacherfüllung bestimmt hat. Hat der Schuldner eine Teilleistung bewirkt, so kann der Gläubiger Schadensersatz statt der ganzen Leistung nur verlangen, wenn er an der Teilleistung kein Interesse hat. Hat der Schuldner die Leistung nicht wie geschuldet bewirkt, so kann der Gläubiger Schadensersatz statt der ganzen Leistung nicht verlangen, wenn die Pflichtverletzung unerheblich ist.

(2) Die Fristsetzung ist entbehrlich, wenn der Schuldner die Leistung ernsthaft und endgültig verweigert oder wenn besondere Umstände vorliegen, die unter Abwägung der beiderseitigen Interessen die sofortige Geltendmachung des Schadensersatzanspruchs rechtfertigen.

(3) Kommt nach der Art der Pflichtverletzung eine Fristsetzung nicht in Betracht, so tritt an deren Stelle eine Abmahnung.

(4) Der Anspruch auf die Leistung ist ausgeschlossen, sobald der Gläubiger statt der Leistung Schadensersatz verlangt hat.

(5) Verlangt der Gläubiger Schadensersatz statt der ganzen Leistung, so ist der Schuldner zur Rückforderung des Geleisteten nach den $\S \S 346$ bis 348 berechtigt.

\$281 Risarcimento del danno in luogo della prestazione per mancata esecuzione o esecuzione della prestazione in modo diverso dal dovuto

(1) Nella misuta in cui il debitore non esegua o esegua in modo non conforme al dovuto la prestazione esigibile, il creditore può pretendere, se sussitono i presupposti del $\S 280$, comma 1, il risarcimento del danno al posto della prestazione, se egli ha inutilmente fissato al debitore un congruo termine per la prestazione o per l'adempimento successivo. Se il debitore ha eseguito una prestazione parciale, il creditore può pretendere il risarcimento del danno al posto dell'intera prestazione, solo quando egli non abbia interesse alla prestazione 
parziale. Qualora il debitore non esegua la prestazione come dovuto, il creditore non può pretendere il risarcimento del danno al posto della prestazione, se la lesione dell'obbligo è irrilevante.

(2) La fissazione del termine non è necessaria se il debitore rifiuta seriamente e definitivamente la prestazione o se sussistono circostanze particolari, le quali, bilanciando gli interessi di entrambe le parti, giustificano il diritto di far valere immediatamente il risarcimento del danno.

(3) Qualora secondo il tipo della violazione dell'obbligo è esclusa la fissazione di un termine, al suo posto subentra l'intimazione.

(4) La pretesa alla prestazione è esclusa, non appena il creditore ha chiesto il risarcimento del danno in luogo della prestazione.

(5) Se il creditore pretende il risarcimento del danno in luogo della prestazione, il debitore ha diritto alla ripetizione di quanto prestato in base ai $\S \S$ da 346 a 348.

\section{$\S 286$ Verzug des Schuldners}

(1) Leistet der Schuldner auf eine Mahnung des Gläubigers nicht, die nach dem Eintritt der Fälligkeit erfolgt, so kommt er durch die Mahnung in Verzug. Der Mahnung stehen die Erhebung der Klage auf die Leistung sowie die Zustellung eines Mahnbescheids im Mahnverfahren gleich.

(2) Der Mahnung bedarf es nicht, wenn

1. für die Leistung eine Zeit nach dem Kalender bestimmt ist,

2. der Leistung ein Ereignis vorauszugehen hat und eine angemessene Zeit für die Leistung in der Weise bestimmt ist, dass sie sich von dem Ereignis an nach dem Kalender berechnen lässt,

3. der Schuldner die Leistung ernsthaft und endgültig verweigert,

4. aus besonderen Gründen unter Abwägung der beiderseitigen Interessen der sofortige Eintritt des Verzugs gerechtfertigt ist.

(3) Der Schuldner einer Entgeltforderung kommt spätestens in Verzug, wenn er nicht innerhalb von 30 Tagen nach Fälligkeit und Zugang einer Rechnung oder gleichwertigen Zahlungsaufstellung leistet; dies gilt gegenüber einem Schuldner, der Verbraucher ist, nur, wenn auf diese Folgen in der Rechnung oder Zahlungsaufstellung besonders hingewiesen worden ist. Wenn der Zeitpunkt des Zugangs der Rechnung oder Zahlungsaufstellung unsicher ist, kommt der Schuldner, der nicht Verbraucher ist, spätestens 30 Tage nach Fälligkeit und Empfang der Gegenleistung in Verzug. 
(4) Der Schuldner kommt nicht in Verzug, solange die Leistung infolge eines Umstands unterbleibt, den er nicht zu vertreten hat.

\section{$\S 286$. Mora del debitore}

(1) Se il debitore non esegue la prestazione a seguito di diffida del creditore, successica all'esigibilità, egli viene costituito in mora mediante la diffida. Alla diffida è parificata la proposizione della azione per la prestazione nonchè la notifica di un decreto ingiuntivo nel procedimento monitorio.

(2) La diffida non è necessaria, quando

1. per la prestazione è fissato un termine secondo il calendario,

2. la prestazione deve essere preceduta da un evento ed è fissato un congruo termine per la prestazione, in modo che questa possa computarsi dall'evento secondo il calendario,

3. il debitore rifiuta seriamente e definitivamente la prestazione

4. l'inizio immediato della mora è giustificato da particolari motivi, bilaciando gli interessi di entrambe le parti.

(3) Il debitore di un credito oneroso è costituito al più tardi in mora se egli non esegue la prestazione entro 30 giorni dall'esigibilità e dall'arrivo di una fattura o di una nota di pagamento equivalente. Ciò vale nei confronti di un debitore, che è consumatore, solo quando nella fattura o nella nota di pagamento si richiama specificamente l'attenzione su tali consequenze. Se il momento dell'arrivo della fattura o della nota di pagamento è incerto, il debitore, che non è consumatore, è costituito in mora al più tarde 30 giorni dall'esigibilità e dall'arrivo della controprestazione.

(4) Il debitore non è costituito in mora fino a quando la prestazione non ha luogo a causa di una circostanza a lui non imputabile.

§ 323 Rücktritt wegen nicht oder nicht vertragsgemäß erbrachter Leistung

(1) Erbringt bei einem gegenseitigen Vertrag der Schuldner eine fällige Leistung nicht oder nicht vertragsgemäß, so kann der Gläubiger, wenn er dem Schuldner erfolglos eine angemessene Frist zur Leistung oder Nacherfüllung bestimmt hat, vom Vertrag zurücktreten.

(2) Die Fristsetzung ist entbehrlich, wenn

1. der Schuldner die Leistung ernsthaft und endgültig verweigert, 
2. der Schuldner die Leistung zu einem im Vertrag bestimmten Termin oder innerhalb einer bestimmten Frist nicht bewirkt und der Gläubiger im Vertrag den Fortbestand seines Leistungsinteresses an die Rechtzeitigkeit der Leistung gebunden hat oder

3. besondere Umstände vorliegen, die unter Abwägung der beiderseitigen Interessen den sofortigen Rücktritt rechtfertigen.

(3) Kommt nach der Art der Pflichtverletzung eine Fristsetzung nicht in Betracht, so tritt an deren Stelle eine Abmahnung.

(4) Der Gläubiger kann bereits vor dem Eintritt der Fälligkeit der Leistung zurücktreten, wenn offensichtlich ist, dass die Voraussetzungen des Rücktritts eintreten werden.

(5) Hat der Schuldner eine Teilleistung bewirkt, so kann der Gläubiger vom ganzen Vertrag nur zurücktreten, wenn er an der Teilleistung kein Interesse hat. Hat der Schuldner die Leistung nicht vertragsgemäß bewirkt, so kann der Gläubiger vom Vertrag nicht zurücktreten, wenn die Pflichtverletzung unerheblich ist.

(6) Der Rücktritt ist ausgeschlossen, wenn der Gläubiger für den Umstand, der ihn zum Rücktritt berechtigen würde, allein oder weit überwiegend verantwortlich ist oder wenn der vom Schuldner nicht $\mathrm{zu}$ vertretende Umstand $\mathrm{zu}$ einer Zeit eintritt, $\mathrm{zu}$ welcher der Gläubiger im Verzug der Annahme ist.

$\S 323$. Recesso per prestazione non eseguita o eseguita in modo non conforme al contrato

(1) Se in un contratto a prestazioni corrispettive il debitore non esegue una prestazione esigibile o la esegue in modo non conforme al contrato, il creditore, dopo aver fissato inultimente al debitore un congruo termine per la prestazione o per l'adimpimento succesivo, può recedere dal contratto.

(2) La fissazione del termine non è necessaria quando

1. il debitore ha seriamente e definitivamente rifiutato la prestazione

2. il debitore non esegue la prestazione nella data prevista nel contratto o entro un termine determinato e il creditore nel contratto ha vincolato la sopravvinza del proprio interessa alla prestazione alla tempestività della prestazione oppure

3. sussistono particolari circostanze che in considerazione degli interessi di entrambe le parti giustificano il recesso immediato.

(3) Se in base al tipo di violazione dell'obbligo non può venire in considerazione una fissazione del termine, ad essa si sostituisce un'intimazione.

(4) Il creditore può recedere prima del sopraggiungere della esigibilità della prestazione, quando è evidente che sussisteranno i pressuposti del recesso. 
(5) Se il debitore ha eseguito una prestazione parziale, il creditore può recedere dall'intero contratto solo se non ha interesse alla prestazione parziale. Se il debitore non ha eseguito la prestazione in modo conforme al contratto, il creditore non può recedere dal contratto se la violazione dell'obbligo è irrilevante.

(6) Il recesso è escluso quando il creditore è responsabile da solo o in misura largamente prevalente per il fatto che lo legittimerebbe al recesso o se il fatto non imputabile al debitore sopraggiunge nel momento in cui in creditore era in mora nell'accettazione.

\section{Espanha}

\section{Código Civil}

Art. 1.100. Incurren en mora los obligados a entregar o a hacer alguna cosa desde que el acreedor les exija judicial o extrajudicialmente el cumplimiento de su obligación. No será, sin embargo, necesaria la intimación del acreedor para que la mora exista:

1. Cuando la obligación o la ley lo declaren así expresamente.

2. Cuando de su naturaleza y circunstancias resulte que la designación de la época en que había de entregarse la cosa o hacerse el servicio, fue motivo determinante para establecer la obligación.

En las obligaciones recíprocas ninguno de los obligados incurre en mora si el otro no cumple o no se allana a cumplir debidamente lo que le incumbe. Desde que uno de los obligados cumple su obligación, empieza la mora para el otro.

\section{França}

\section{Código Civil}

Art. 1.135. Les conventions obligent non seulement à ce qui y est exprimé, mais encore à toutes les suites que l'équité, l'usage ou la loi donnent à l'obligation d'après sa nature.

Art. 1.146. Les dommages et intérêts ne sont dus que lorsque le débiteur est en demeure de remplir son obligation, excepté néanmoins lorsque la chose que le débiteur s'était obligé de donner ou de faire ne pouvait être donnée ou faite que dans un certain temps qu'il a laissé passer. La mise en demeure peut résulter d'une lettre missive, s'il en ressort une interpellation suffisante. 
Art. 1.147. Le débiteur est condamné, s'il y a lieu, au paiement de dommages et intérêts soit à raison de l'inexécution de l'obligation, soit à raison du retard dans l'exécution, toutes les fois qu'il ne justifie pas que l'inexécution provient d'une cause étrangère qui ne peut lui être imputée, encore qu'il n'y ait aucune mauvaise foi de sa part.

\section{Itália}

\section{Código Civil}

Art. 1.218. Responsabilità del debitore.

Il debitore che non esegue esattamente la prestazione dovuta è tenuto al risarcimento del danno, se non prova che l'inadempimento o il ritardo è stato determinato da impossibilità della prestazione derivante da causa a lui non imputabile.

Art. 1.222 Inadempimento di obbligazioni negative.

Le disposizioni sulla mora non si applicano alle obbligazioni di non fare; ogni fatto compiuto in violazione di queste costituisce di per sé inadempimento.

Art. 1.374. Il contratto obbliga le parti non solo a quanto è nel medesimo espresso, ma anche a tutte le conseguenze che ne derivano secondo la legge, o, in mancanza, secondo gli usi e l'equità.

Art. 1.456. Clausola risolutiva expressa. I contraenti possono convenire espressamente che il contratto si risolva nel caso che una determinata obbligazione non sia adempiuta secondo le modalità stabilite. In questo caso, la risoluzione si verifica diritto (1517) quando la parte interessata dichiara all'altra che intende valersi della clausola resolutiva.

\section{Portugal}

\section{Código Civil}

Art. 335. Colisão de direitos.

1. Havendo colisão de direitos iguais ou da mesma espécie, devem os titulares ceder na medida do necessário para que todos produzam igualmente o seu efeito, sem maior detrimento para qualquer das partes. 
2. Se os direitos forem desiguais ou de espécie diferente, prevalece o que deva considerarse superior.

Art. 799. Presunção de culpa e apreciação desta.

1. Incumbe ao devedor provar que a falta de cumprimento ou o cumprimento defeituoso da obrigação não procede de culpa sua.

2. A culpa é apreciada nos termos aplicáveis à responsabilidade civil.

Art. 804. Princípios gerais.

1. A simples mora constitui o devedor na obrigação de reparar os danos causados ao credor.

2. O devedor considera-se constituído em mora quando, por causa que lhe seja imputável, a prestação, ainda possível, não foi efectuada no tempo devido.

\section{Projetos de unificação do direito dos contratos}

\section{Princípios Unidroit}

Art. 5.1.4. Duty to achieve a specific result. Duty of best efforts.

(1) To the extent that an obligation of a party insolves a duty to achieve a specific result, that party is bound to achieve thar result.

(2) To the extent that an obligation of a party involves a duty of best efforts in the performance of an activity, that party is bound to make such efforts as would be made by a reasonable person of the same kind in the same circumstances.

\section{Draft Common Frame of Reference}

Art. III. - 1:109: Variation or termination by notice. (1) A right, obligation or contractual relationship may be varied or terminated by notice by either party where is provided by the terms regulating it.

\section{Tratados internacionais}


Convenção de Viena de 1980 sobre os contratos de compra e venda internacional de mercadoria

Article 25 - A breach of contract committed by one of the parties is fundamental if is results in such detriment to the other party as substantially to deprive him of what he is entitled to expect under the contract, unless the party in breach did not foresee and a reasonable person of the same kind in the same circumstances would not have foreseen such a result. 


\section{RESUMO}

O esforço teórico trata da caracterização e das consequências do inadimplemento recíproco nos contratos de distribuição. Trata-se de tema que se situa nos limites entre direito civil e direito empresarial. Isso, de um lado, o torna pouco estudado e, de outro, cria a necessidade de se debruçar, acuradamente, sobre dois pilares: o direito obrigacional e o contrato de distribuição, marcado pelas especificidades das categorias de contrato de duração e de colaboração.

No âmbito do direito obrigacional, convém ter desde logo presente que o Código Civil disciplina tão somente o inadimplemento singular, relacionado à inexecução das obrigações contraídas por apenas uma das partes. Nada dispõe, porém, a respeito do incumprimento por ambos os contratantes, razão pela qual se mostra oportuna à intervenção da doutrina no particular.

A questão assume especial relevância no âmbito do contrato de distribuição. Referido negócio é estruturado para protrair-se no tempo e reclama esforços conjugados para o escoamento da produção, de maneira que o inadimplemento recíproco nele ocorrido causa discussões a respeito da adequação das regras constantes no Código Civil para arranjos mais sofisticados, especialmente, no que tange à transformação da mora em inadimplemento definitivo e ao cabimento da resolução da relação contratual.

A justiça brasileira e a doutrina tateiam diversas soluções, calcadas na compensação de culpas, na culpa determinante e na boa-fé objetiva. Não há, entretanto uma orientação consolidada sobre o tema, especialmente, diante do inadimplemento recíproco do contrato de distribuição, o que, acredita-se, justifica o percurso investigativo que ora se propõe. 


\section{RIASSUNTO}

Lo sforzo teorico è diretto ad esaminare la caratterizzazione e le conseguenze dell'inadempimento reciproco nei contratti di distribuzione, tema che si trova al confine tra diritto civile e diritto commerciale. Tale circostanza fa si che, da un lato, l'argomento sia poco studiato e, dall'altro, sia necessario approfondirne l'esame, tenendo presente i suoi due pilastri ovvero: il diritto delle obbligazioni e il contratto di distribuzione, segnato dalle caratteristiche dei contratti di lunga durata e di collaborazione.

Nell'ambito del diritto delle obbligazioni, giova tener presente sin d'ora che il Codice Civile disciplina soltanto il singolo inadempimento, relativo alla mancata esecuzione delle obbligazioni a carico di una delle parti. Nulla dispone il testo legale, però, sull'inadempimento di entrambe le parti, ragione per cui si ritiene opportuno l'intervento della dottrina sull'argomento specifico.

La questione assume particolare rilievo nell'ambito del contratto di distribuzione. Tale negozio è concluso per protrarsi nel tempo e richiede sforzi congiunti affinché i prodotti siano posti sul mercato. Di conseguenza, l'inadempimento reciproco verificatosi nell'ambito del contratto di distribuzione suscita discussione sull'adeguamento delle regole costanti del Codice Civile per disciplinare operazioni più sofisticate. I problemi principali riguardano la trasformazione del ritardo in inadempimento definitivo e la portata della risoluzione del rapporto contrattuale.

La giurisprudenza e la dottrina brasiliana discutono diverse soluzioni fondate sulla compensazione della colpa, sulla colpa determinante e sulla buona fede oggettiva. Tuttavia, non si trova un orientamento consolidato sull'argomento, soprattutto per quanto riguarda l'inadempimento reciproco nel contratto di distribuzione, circostanza che giustifica il percorso di investigazione qui proposto. 